

$$
\text { ฮั }
$$





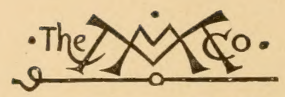

THE MACMILLAN COMPANY

NEW YORK - BOSTON - CHICAGO

ATLANTA - SAN FRANCISCO

MACMIILAN \& CO., LIMITED

LONDON - BOMBAY - CALCUTTA

MELBOURNE

THE MACMILLAN CO. OF CANADA, LTD, TORONTO 



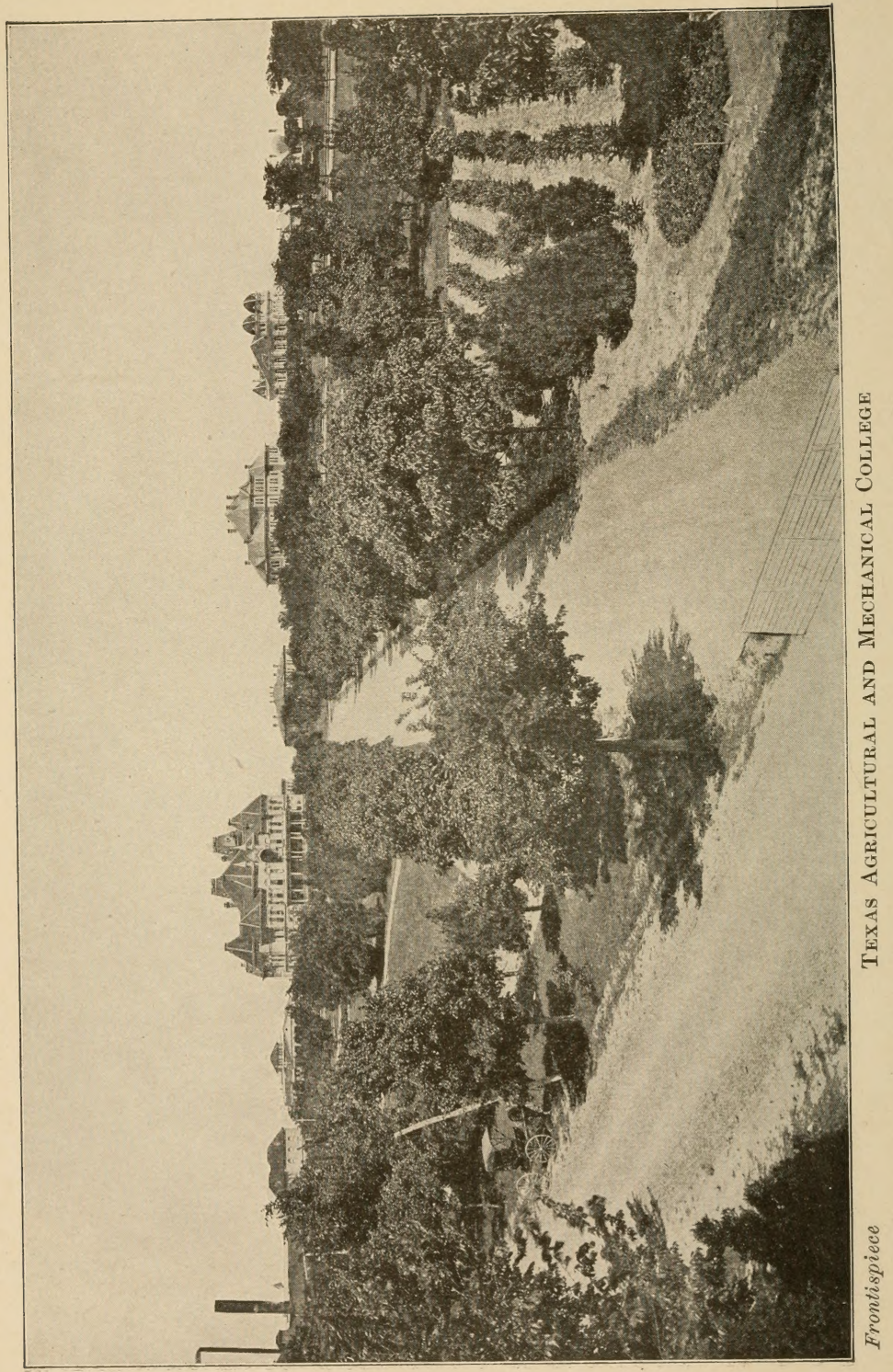




\section{ELEMENTS OF AGRICULTURE}

\section{SOUTHERN AND WESTERN}

BY

W. C. WELBORN, B.S., M.S., M.P.A. VICE-DIRECTOR AND AGRICULTURIST OF THE TEXAS EXPERIMENT STATION

Xrew 聰ark

THE MACMILLAN COMPANY

1908 


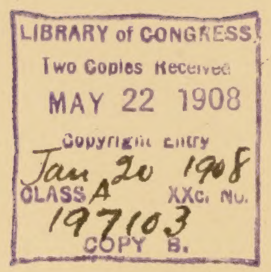

Cor'̌ight, 1908,

By THE MACMILLAN COMPANY.

Set up and electrotyped. Published April, 1908.

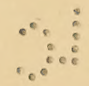

MANUFACTURED BY

BROCK \& RANKIN,

CHICAGO. 


\section{PREFACE ANI SUGGESTIONS}

THE author feels no hesitation in taking the ground that agriculture has an educational, or mind-training value, fully equal to geography or history. The facts presented in agriculture are quite like those of physical geography in particular; the description of the development of crops, live stock, and agricultural industries generally is the very best of history. In addition, the study of agriculture has a manifest advantage in training the habits of observation, as it treats of things that are about us - that may be seen, heard, and felt - and therefore truly educates through the environment of the pupil.

If a geography class could be taken to Mount Vesuvius and could see the great volumes of ashes, cinders, and lava that are belched forth, covering hundreds of square miles with rich soil, what a lesson it would be in worldbuilding and what an inspiration to the whole school and the whole community! In agriculture we teach facts that may be verified on the farm, in the garden, by the roadside, and in the forest, and facts, too, of greater importance by far to that community than the operations of the far-away volcano. Beyond all this, agriculture will impart a mass of useful information about the greatest business in this country, which farmers cannot any more 
afford to do without than doctors could afford not to know that the blood circulates. This information, put into the minds of pupils generally, will be imparted in a great measure to the present generation of farmers, and will be reflected in better methods and better results on the farms of the country.

Agriculture can without any doubt be taught as easily as any other subject, if the truth is told, if it is put into simple language, and is arranged in fairly logical order. This book has aimed to meet these conditions, and on account of the want of preparation on the part of many teachers, has a faithful list of questions at the end of each chapter. No one can answer the questions without understanding the subjects. It is believed the questions will be a great help to teachers and pupils, and will enable any teacher to teach the subject quite as easily as geography or history can be taught. Indeed, it is believed that most teachers in country districts actually know much about agriculture, although they may never have read any book treating it.

The author does not believe that most country teachers will have time and means to provide a large amount of illustrative material in the way of a farm, live stock, garden, orchard, and laboratory. Teachers of history and of geography are not expected to follow any such method, and their only illustrative material consists of pictures, or maps and globes, of things generally removed a thousand miles of distance or a hundred years in time. The principles of agriculture could be taught as well by the same means. Whenever a teacher is fortunate enough 
to have a pupil who has seen the battletield of Gettysburg, it is never difficult to teach the history and geography of that whole region to that pupil and to the whole class. In teaching agriculture you teach something that all the pupils and their parents know something about, and their interest will be keen. An appeal to what the pupil has seen or can see for himself will in a great measure compensate for any lack of direct illustration. You are teaching something about the pupii's old friends and accuaintances, and you are less dependent on experimental work on this account.

It is not believed that any considerable percentage of the schools are in position to make agriculture more of an outcloor than a class-room subject. Neither is it advised in teaching this book to try to vary the order of chapters taught to better fit the seasons for experimental work. Agriculture is certainly a valuable classroom study; it should be so used, and calling to mind what the pupils have experienced and stimulating them to find more will constitute the best experiments. Then make all the suggested experiments and observations that time and means will permit. 'Try to get still others made by the patrons, who should always be consulted on account of their invaluable practical experience. Remember, these farmers know more than the author of your text-book about many agricultural matters.

In preparing this book the author supposes that its readers are acquainted to some extent with agricultural matters from practice and observation. The smaller details of information have been left to be got in some other way, if not already known. Only the general truths 
and useful principles about the main features of agriculture have been attempted.

No attempt has been made to agree with other authors; in fact, in many very important matters, views directly (1)posite to those of most agricultural writers have been taken. Agriculture as a science is new. Much that we believed true ten years ago has been disproved. The discreclit attaching to so-called "book farming " no doubt (“ame about from the widespread publication of so much matter that was untrue and hurtful to those attempting its practice. The Igricultural Experiment Stations of the country have given us the most reliable agricultural literature we have in the record they have marle of their own research and of the practical work of farmers with whom they have coöperated. In differing with other authors, most of whom wrote a number of years ago, this work is in substantial agreement with the combined results of all the experiment stations, so far as these results have been published. It is fully believed that in this little volume enough of truth applicable to the sections intended to be served will be found, and enough of error has been pointed out to make the book one of general usefulness.

While written for the schools, this work should be 110 less valuable for the farmer and general reader. The fact that it gives useful information about agricultural affairs in language easily understood, being otherwise suitably arranged for school work, should make it only more valuable to the farmer, who is a student no less than the public school pupil. 
The author has received valuable help and advice from I)r. II. H. Harrington, President of the Texas Agricultural and Mechanical College, and Dr. C. P. Fountain, Professor of English, who patiently criticised the entire work. He is under obligation also to almost the entire faculty of the above-named institution for kind assistance.

JiNuARY 13, 1908. 



\section{CONTENTS}

OHAPTER

I. The Resources of the Farmer . . . . 1

II. The Bullding of a Plant . . . . . 5

III. The Making of the Soll. . . . . . 8

IV. KINDS OF SOIL . . . . . . . . 15)

V. Ratefall and Productrons of Texas . . . 29

VI. Chemistry of Soll axd of Plants . . . :31

VII. The Physics of the SolL: Storage of Water .

VIII. Bacteria or Germ Lifie. . . . . Hi

IX. The Botany of our Crops . . . . . 52

X. Grafting and Budding . . . . . (i:

XI. Sefid Selection . . . . . . . diti

XII. TMrroving the Land. . . . . . . Ts

Xili. Rotation of Crops. . . . . . siti

XiV. Manures and Fertilizers . . . . !2

XV. Commercial Fertilizers. . . . . .

XVI. Plowing . . . . . . . . . . $1111 ;$

XVit. Preparation for Planting . . . . 11:2

XVIII. Irrigation . . . . . . . . 11!1

XiX. Insect Friends And Exemins. . . . 1.5

XX. Cotton. . . . . . . . . . 19:5

XXI. Corn . . . . . . . . . . 149

XXII. WheAt AND OATS . . . . . . 1.5t

XXIII. RICE . . . . . . . . . 16.-

XXIV. Sugar Cane. . . . . . . . . 16i!

XXV. The Sweet Potato . . . . . . . 17t; 
GHATER

XXVT. The Cowpla ani PeAnut . . . . . 181

XXVII. 'J'овассо. . . . . . . . 1St;

XXVIII. Sorghum, Kafir, and Milo-MaIze . . . 1!)

XXIX. The Velvet and Soy Beans, Alfalfa, IIAry VETCII

XXX. The Clovelis axi Mrxor Cropi . . . 201

XXXi. Other Hay and Pasture Gliasse. . . DUS

XXXII. Orchard Ćrops . . . . . . 21.

XXXII. TruCK Crops. . . . . . . . . . . . .

XXXIV. 'The Feeding of Aximals . . . . . . 2:34

XXXV. The Making of a RAtion. . . . . 24t

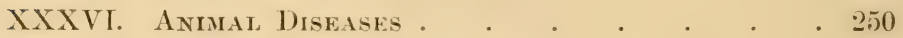

XXXVIT. Animat Husbaniry . . . . . . 255

XXXVII. Raising Horses ANI MULES . . . . 258

XXXIX. Cattie . . . . . . . . . . . 263

XL. Hogs, Sheep, Godts, Poultry, axi Bees . 275

XLI. Dairying . . . . . . . 286

APPENDIX . . . . . . . . . . 295

Gilossary . . . . . . . . . . . . . . . . . . .

INDEX . . . . . . . . . . . . . . . . . . . . . . 


\section{LIST OF ILLUSTRATIONS}

Texas Agricultural and Mechanical College

Frontispiece FIG.

1. Sprouting Pea

2. Weathering of Rock, forming Soil a . . . . 9

3. Glacier in the Alps . . . . . . . . 11

4. Where a Glacier Melts . • . . . . . . 12

5. Trees assist in breaking Rock . . . . . . 13

6. Soil Divisions of Texas . + . . . . . . 16

7. Alkali Land . . . . . . . . . . 17

8. Former Inhabitants of the Plains . . . . . . 20

9. Present-day Scene on the Plains . . . . . . 21

10. Soil Areas of the Cotton Belt . . . . . . 25

11. Rainfall Map of Texas . . . . . . . . 29)

12. Showing Capillary Action of Soils . . . . . . 39

13. Stirring Soil when Wet and when in Right Condition . . 42

14. Different Bacteria greatly Magnified . . . . . 46

15. Tubercles on Roots of Legumes . . . . . . 48

16. Fibrous Roots of Corn . . . . . . . . . 55

17. Osmosis . . . . . . . . . . . . 57

18. Flower of the Apple . . . . . . . . . . 5

19. Lily of the Valley . . . . . . . . . 58

20. Steps in Budding . . . . . . . . . 63

21. Ring Budding for Oranges and Pecans . . . . . . 64

22. Grafting . . . . . . . . . . . 65

23. The Proper Depth to plant Fig Cutting _ . . . 65

24. Old Pecan Tree growing Paper-shell Buds . . . . . 66

25. Testing Seed • • . • • • . . . . 69

26. Pure and Impure Alfalfa Seed . . . . . . 71

27. New Mexico Date Palm. . . . . . . . 75 
rie:

28. Terraced Land

29. Corn Grown on Washerl and on Terraced Land . . S1

:3). Terraced Land and Rows

:1. Best Shitpe for an Open Ditch

:32. Tile Draining .

:3:). Cowpeas and Sweet Sorghum

:3. Hogs grazing Cowpeas .

3.). Fertilized and Unfertilized Cotton

:36. Sandy-land Plow

:7. Black-land Plow

:38. Steam Plow on the Plains

:39. Sub-surface Packer.

40. Irrigating between Rows

11. Spraying Fruit Trees .

12. Boll Weevil and Larva .

43. Different Life Sizes of Adult Boll Weevils .

11. Punctured Square containing Young Weevils

4.). Early and Late Cotton in Boll Weevil Distriet

4t. Good Type of Cotton Plant

17. Poor Type of Cotton Plant

48. liolling Fresh Cotton Berl to firm the Soil for Planting . 1:38

49. Mississippi Cotton Field

50. Round Cotton Bales

51. Long and Short Staple Cotton

52. American Bale of Cotton as it gets to Europe

53. Corn and Cowpeas .

54. Wheat planted in Loose Soil and in Soil Compracted .

5.). Wheat Field on the Plains

56. Oats and Vetch

57 . Rice Field in Louisiana . . . . . . . . . 16:3

58. Filipinoes plowing in Mur, prejaring Land for Rice . . 164

59. Seeded Sugar Cane

(i). Way to use a Saccharimeter . . . . . . . 172

61. Cutting Sugar Cane in Louisiana . 
PIG.

62. Hill of Sweet Potatoes . . . . . . . . 177

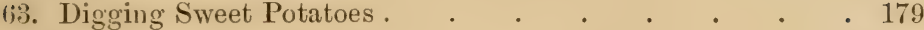

64. Spanish Peanuts . . . . . . . . . . . 183

65. Saving Peanuts . . . . . . . . . . 184

(i6. Tobacco growing under Cheese-cloth Shade . • • • 187

67. Harvesting Sorghum . . . . . . . . . . 191

68. Field of Kafir Corn . . . . . . . . . . . . 193

69. Soy Bean . . . . . . . . . . . . 197

70. Stacking Alfalfa Hay . . . . . . . . . $19 \mathrm{~S}$

71. Red Clover . . . . . . . . . . . . 201

72. Crimson Clover . . . . . . . . . . . 20:3

73. Florida Beggar IVeed . . . . . . . . . . 204

7. Rape Field . . . . . . . . . . . . . 205

75. Jerusalem Artichoke . . . . . . . . . . 206

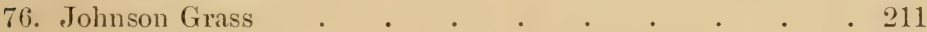

77. Guinea Grass, Biloxi, Mississippi . . . . . . 212

7S. Intensive Farming - Chinese in IIawaii grow Four Crons at Once . . . . . . . . . . . 215

79. Irrigating an Orchard . . . . . . . . . . 216

S0. Well-trinmed Texas Peach Tree . • • . • • . 217

81. San José Scale on Peach Trees . • • • • • • 218

S2. Cocoanut Plantation as seen in Florida, Porto Rico, IIawaii, and the Philippines . . . . . . . 219

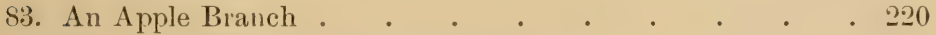

84. Figs at the Texas Experiment Station . . . . . . 221

S5. Smyrna Fig 'Trees, California * • • • • • . 222

86. Grape Fruit at Beeville, Texas, Branch Experiment Station 224

87. Texas Orange Tree . . . . . . . . . 225

88. Harvesting Irish Potatoes . . . . . . . . . 227

89. Small Hotbed . . . . . . . . . . . 299

90. Gathering Tomatoes . . . . . . . . . . . 230

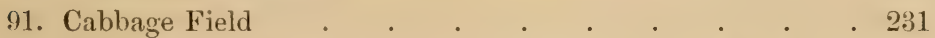

92. Southwest Texas Steers being fattened on Cactus and Cotton-seed Meal 
FIS.

93. Coach Type . . . . . . . . . . 25!

94. Draft Type: Percheron . . . . . . . 2060

95. Zebu, or Sacred Bull of India . . . . . . - $2(;:)$

96. Dual P'urpose Cattle: Deron and Red Poll . . . . • 20.5

97. Beef Cattle: Short Horn and Hereford . . . . 2017

98. Showing Beef Cattle at the Texas Agricultural and Mrchanical College . . . . . . . . .

99 Breeds of Swine: Tamworth and 1)uroc Jersey . . . 27t;

100. Breeds of Swine: Poland China and Berkshire . . . 느

101. Razor Backs for Want of Feed . . . . . . . 2 - .

102. Movable Fence . . . . . . . . . 27!

103. Sheep and Goats . . . . . . . . . 281

104. Flock of Angoras . . . . . . . . . 281

105. Sheep Ranching in the West . . . . . . 2S:2

106. Plymouth Rock Hen . . . . . . . . 28:;

107. Brown Leghorn Hen . . . . . . . . 28:;

108. Bronze Gobbler . . . . . . . . . 2St

109. Round Silo . . . . . . . . . . . . . . . . . .

110. Dairy Cows : Jersey and Holstein Dehorned . . . 2.Ss

111. Cream Separator . . . . . . . . . 290

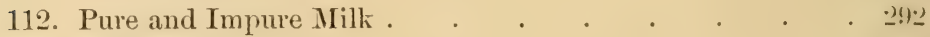

113. Box Churn . . . . . . . . . . 2!):; 


\section{ELEMENTS OF AGRICULTURE SOUTHERN AND WESTERN}

\section{CHAP'TER I \\ THE RESOURCES OF THE FARIMER}

UsU A LLY the first object of the farmer is to grow plants. 'These may be used or sold, or they may be fed to animals, and the animals or animal products used or sold. For example, cotton may be grown and sold, and the seed may be fed to cows, and milk and butter produced for home use and for sale.

Plants Necessary for Man and Animal Life. - The earth and the air are rich in the things needed to produce bone and muscle and blood. Yet animals would starve if they tried to live on rock, or earth, which is only ground-up rock. Man and his servants, the other animals, cannot digest rock or earth. Neither can they use to build up' their bodies any of the gases of the air they breathe.

Plants, however, our other servants, send their little threallike roots all through the soil. These roots twine themselves about the little rocks, or soil grains, and suck from them the substances they need for growth. Their green leaves, too, through little openings or breathing pores, known as stomutu, take in the gases of the air, and find in these one of the most important things needed to 
make them large and strong. This same element is also -needed for the growth of our bodies, and since we can get none of it from the air, we must get our supply by eating plants or substances obtained from plants. So, by eating and digesting the plants, we can use the materials the plant roots get from the soil.

Earth, Air, and Water. - All the animal kingdom, including man, is made up of the elements of the earth, the air, and the water. Water is the only one we can use for growth without the help of plants, but we cannot live on water. If it were possible that all the plant world could go on a strike, animal life perhaps could not endure on the earth more than a month.

Plants purify the Air. - Our faithful servants of the plant kingdom not only stand between us and starvation, but also purify the air that we breathe. When we breathe the air, part of the oxygen gas we take in is used in the lungs to purify our blood. In its place we exhale, or breathe out, a gas called carbonic acid gas. The air of a closed room which contains very much of this gas is unfit for breathing.

Plants use Carbonic Acid Gas. - When green leaves take in air, they use the carbon of the carbonic acid gas which the air contains, and give out pure oxygen. If it were not for this work of plants, the whole atmosphere would become so filled with carbonic acid gas as to be like a small, close room. Animal life would probably soon cease for want of pure air. You may ask why we do not die in winter when there are few green leaves. Your geography teaches that the trees are green in winter 
throughout the Southern hemisphere, and are green in the torril zone all the time. Winds bring pure air to us in winter, and carry away the air of our zone to be purified.

Animal Life of Use to Plants. - Animals in tur'n give off from their lungs carbonic acid gas for plants. But the burning of wood and coal and the rotting of leaves, wood, and other vegetable matter also make this gas. So the plants could live without the animals, but probably they would not thrive quite so well. As animals, including all worms, insects, etc., die, their bodies rot and add richness to the land. Earthworms and many other lower forms of animal life make holes in the soil, let in air, assist water to drain away, and by eating parts of the soil and grinding it make it finer and richer.

Animal Manures. - The larger farm animals, such as cows, horses, sheep, and hogs, eat grasses, weeds, corn, and other foods. The horses and mules give us work; the cows, milk and butter and beef; and the hogs, pork and lard. At the same time, if the farmyard manure is saved and used on the land, the fertility of the soil will be kept up and the crops will be large.

Value of Manure. - It is often true that the manure produced by live stock is worth more than the cost of the food eaten by them. This is true in feeding cotton seed when it sells for a low price. Then certain hay crops, such as peas, peanuts, alfalfa, and others, get their most costly fertilizing ingredient from the air. Even when these crops are cut for hay, their roots enrich the land. If the hay is fed to stock, very rich manure is produced. With plenty of live stock and crops like these to feed 
them, we would have very fertile land. These things will be discussed at length later on.

\section{QUESTIONS}

What products do farmers grow? Give examples. Why could not animals live without plants? Where do the materials that our bodies are made of come from? From what different sources do plants get the materials to grow with? What effect do plants have on the air we hreathe? Why do auimals make the air hetter suited to nourish plants? What is the name of the gas that plant leares take in from the air? IIow does the air beenme purified in winter? What efferet. does animal life have on the fertility of the land? May animal manures ever have more value than the cost of the foods the animals eat? Why? Why do certain crops enrich the land rapidly?

Observation. - Did you ereer notice where old horse lots or catle pens have been put into cultivation how rich the land is, and how long it remains rich? 


\section{CHAP'TER II}

\section{THE BUILDING OF A PLANT}

Ix order to grow plants we need seed, soil, moisture, air, warmth, and light. Some plants, such as weeds, and even some useful plants, need no sowing or cultivation.

The Seed. - A seed is generally a little package of rich foodstuff for young plants, containing a germ, or young plant itself. The germ and the food are usually dry so as to keep well, and are covered with a nearly waterproof coat to preserve them till a suitable season for growing comes.

The Seed and Root. - When the weather becomes warm enough, the seed is sown in moist soil, the germ sprouts or swells and begins to grow. The little plant uses the food stored up in the mother seed

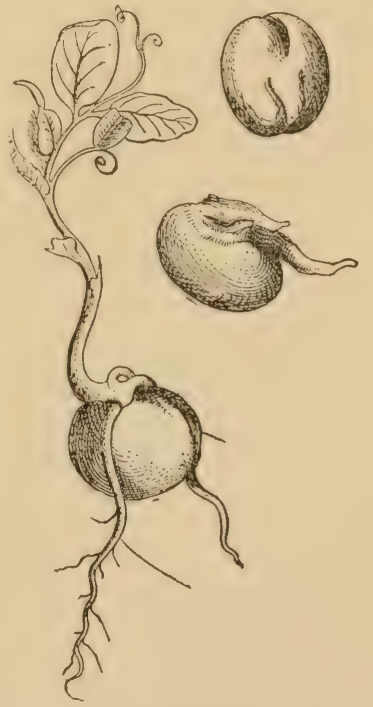

Fig. 1. - Sprouting PeA at first, till it can send out little roots through the soil to gather food and water for itself.

The Root, Stem, and Leaf. - In the meantime the plant has made a stem, and on top of this have grown some 
green leaves. These leaves have little openings, and the stems of the plant have little 'hammels for the food and water to pass up and down. Is alreary learned, the stomata of the leaves take in (arlmic acid gas with the air. By the aid of sunlight the green leaf takes the carhon, combines it with water, and makes sugar, starch, wood, and other materials. The leaf gives off the oxygen pure for us to breathe.

What Plants are made of. - About half the weight of dry plants is carbon, most of which is gotten from the air. So we see the leaves are quite as useful in feerling. plants as are the roots.

Air, Water, and Soil as Food for Plants. - Nine tenths or more of the weight of dry plants is marle up of ele.ments which plants get from water and air together. ()ne tenth, or generally less, is marle up of materials drawn from the solid earth. Burn a plant, and the part it got from the air and water will go off in smoke and other gases. The part that came from the solid earth will remain as ashes.

When plants, or parts of plants, rot the same thing. happens: the part that comes from the air goes back to the air, and the part that comes from the earth goes hack to the earth.

Plants build Animals. - The ash of plants is the part that makes the bones of animals, while the sugar, starch, and oils of plants produce the fat of the animal body, and also supply heat to keep the body warm and force to produce motion and work. Most plants produce some sugar, as sugar cane; some starch, as corn; and some oil, as cot- 
ton seed. Other constituents in plants prorluce in animals muscle, fat, blood, hair, skin, ete. We will cliscuss these things more at length later.

The Main Purposes of Plants. - The main purpose of every plant appear's to be to produce seed, or in some other way to make other plants of the same kind. People and animals sometimes consume the seed, roots, or stems that would produce new plants, and sometimes parts that would not reproduce. The new seeds are generally the most valuable for food, as in the case of rice, wheat, and corn.

\section{QUESTIONS}

What is a seed, and what does it contain? What provision is made in every seed for the young plant to grow from it? Of what use are leaves of plants? How do plants get their solid foor from the soil? Does a plant use all the water the roots take in from the soil? Do plants get more of their food from the air or from the earth? What common substances does the plant make out of the carbon it gets from the air and the water it takes from the soil? About what part of the dry weight of a plant is derived from the soil? What part came from the air? Where did the other part come from, and how much does that make of the whole? If you burn a plant, where do these materials go? How nearly is rotting of plants like hurning them? What part of plants makes the bones of animals? What do the sugar, starch, and oils of plants produce in the body of the animal? Do all plants produce some sugar, starch, and oil? What parts of plants do people and animals use?

Experiment. - Weigh a bundle of dry grass; hurn it and weigh what is left. You can do this at school during recess. 


\section{CHAPTER III}

\section{THE MAKING OF THE SOIL}

The Soil and how it is Formed. - Although plants get fully half of their food from the air, we cannot change the air to make it better fitted for growing them. Plants get almost all the other half of their food from water, and all their soil food by the help of water. We can supply water sometimes, and can always so work the land as to make the rain water in the soil last a long time during drought.

The soil itself affords no more than ten per cent of the weight of plants, and sometimes not over one or two per cent. Yet we can often so work the land and fertilize it as to double our crops.

Soil made of Rock. - The earth was once covered with solid rock. Now it is generally covered with decomposed rock to a depth of a few feet to a hundred or more feet. This powdered material is called soil. 'The top' layer of this for a few inches is generally darker in color than the deeper layers, and is called top soil, or snil, while the layer under this for some distance is called subsoil. The upper layer is generally dark in color because there is mixed with it rotting leaves, stems, and roots of plants. This material is often called humus. Plows generally run about deep enough to turn over this top soil, leaving the subsoil unbroken. 
How the Rock was ground up. - (ieology, the seience which teaches the past history of the earth, tells us some interesting stories about how the soil was mate. The surfice of the earth was at first covered with melted rock, surrounded by air containing water vapor, as we find the

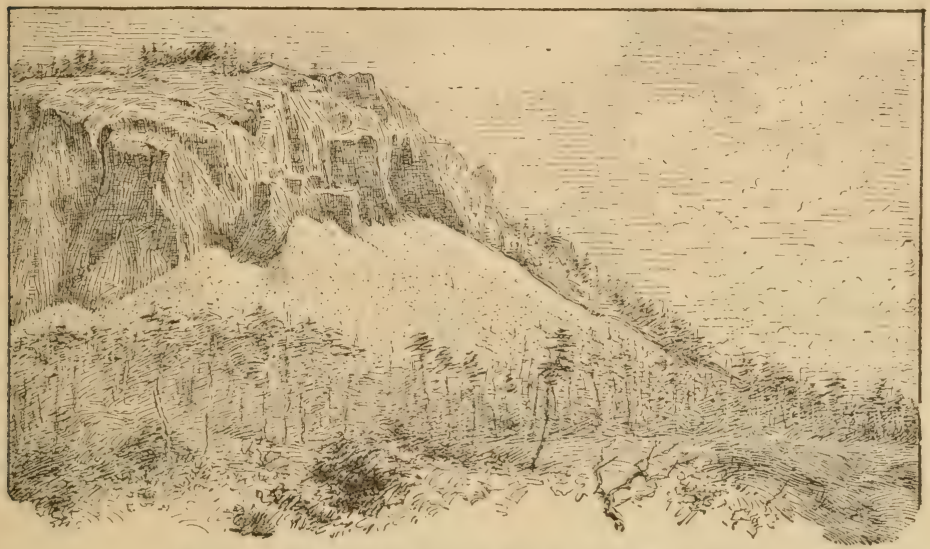

Fig. 2. - Weathering of Rock, Forming Soil

air to-day. As the vapor high in the air became cold, it formed rain, which fell on the hot rock. Of course the rain cooled the rock and cracked it. As the rain water was heated, it rose in steam, and reaching the higher air, grew cold, and was again condensed into rain. Again it fell and cooled and cracked the rocks still more. Finally the rocks became cool enough for the rain to form little streams, and to wash and grind the little pieces of broken rock, and separate the coarser from the finer pieces.

As the whole surface of the earth cooled, mountains and valleys, hills and hollows, were formed. Many large (racks, or seams, were also made in the earth's crust. 
Cold weather came; rain filled all the erevices and cracks of the rocks, and froze. You know how ice will break pitehers, vases. or bottles. When water freezes. it expands with resistless forec. ()f comre the rocky surface was split by the ice. When the ice melted, the water formed into swift streams, carried the broken rock along : deposited bowlders here, gravel yonder, sand at another. place, and fine soil at still another.

Streams are stealily doing the same things to-day. Rocks are still being broken throughout the mountain regions by rain and ice, variation of temperature, winds. and other agencies.

Early Plant Life. - While soil Was thus being made. lower forms of plants, like lirhens and mosses, came and fastened themselves to the rocks. The roots of plants seem to give out an acid that eats away, or dissolves. the rock. These low forms of plants may be seen to-day slowly eating away old gravestones and stone walls and huilrlings. Plant roots will cut furrows in the surfaces of Hower pots. When these first plants died, they added some humus to the soil and mate it better. This fitterl the soil for higher plants. Finally, animals of the lower kinds appeared, and when they died their bodies becance a part of the soil.

Glaciers. - At one period in the earthis history there was intense cold everywhere. Much of the water valuri of the whole air fell as snow or sleet. Whole valleys were tilled with moving ice, and formed what are known as glaciers. (One of these, which extenderl over part of the morthern portion of the Inited States is said to hate: 
been a thousand feet deep and a thousind miles wide. It moved toward the south, tearing away rocks, and cutting arvay parts of hills and mountains.

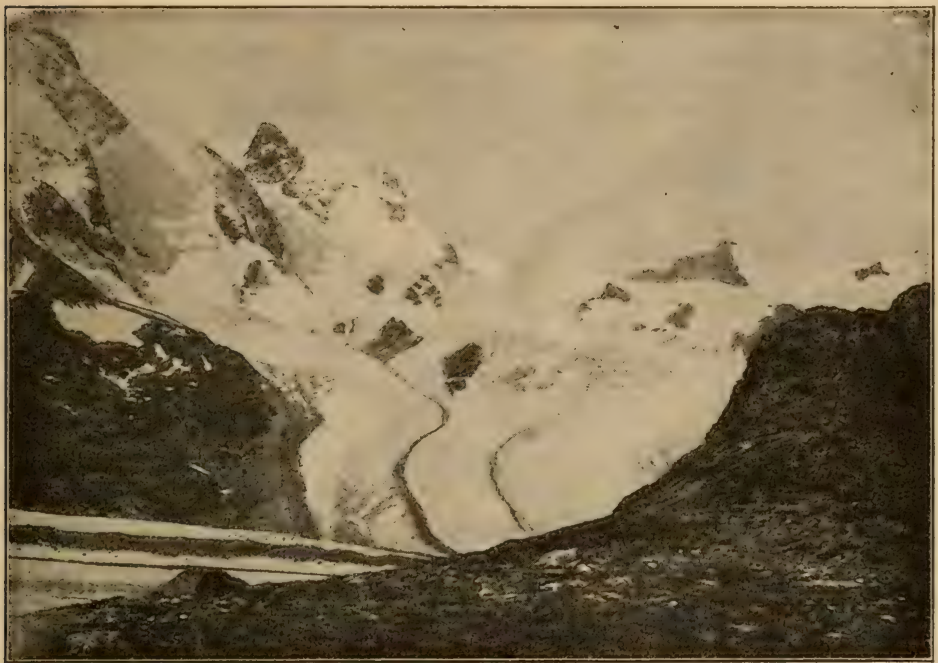

Fig. 3.-GLACIER IN THE Ar.PS

Most of the rocks thus collected sank to the bottom of the ice mass, and scoured the solid rock of the earth until they ground themselves into powiler. Thus enough fine rock dust was made to cover a good part of the continent with soil. This deposit, left after the melting of the ice. is known as drift soil.

Stream Action. - The work of moving and sorting the materials by the streams has never ceased. Every creck or river moves rock, gravel, sand, or fine sediment. When a swift stream overflows its banks, the current of the water. 
is checked, and its gravel and sand are allowed to settle. When the water gets farther away from the chamnel and begins to rum more slowly, it allows fine mud to settle. In this way stiff, muddy soils are made.

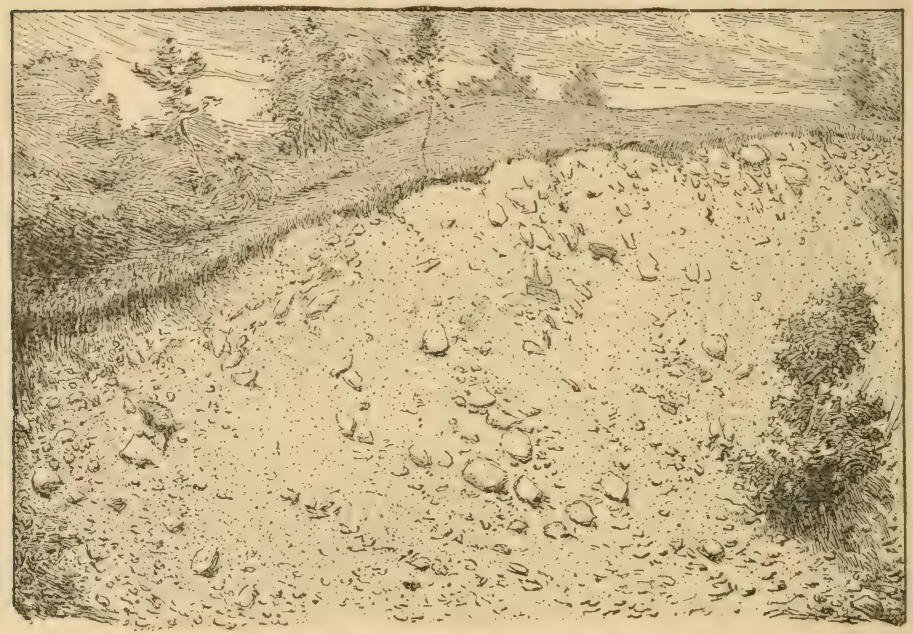

Fig. t. - Whierl a (ilacier Melts

Wind-blown Soils. - Not only do ice and running water move soils, but in dry countries the wind blows enough dust and sand to build up the land several feet deep. Streams have been filled, railroad tracks covered, and even cities have been buried by wind-blown soil. Just north of the Canadian River in IIemphill County, Texas. is a beautiful example of wind-formed soil. The southwest wind has blown away the fine particles of soil and left great mounds of coarse sand for many miles. Farther morth finer particles settled and formed a loam soil. Sili 
farther north the finest soil settled and made a silt or claty soil.

Sedentary Soils. - While much soil has been transported from where it was first made from rock, much of the earth's surface is covered by soil male from the rock

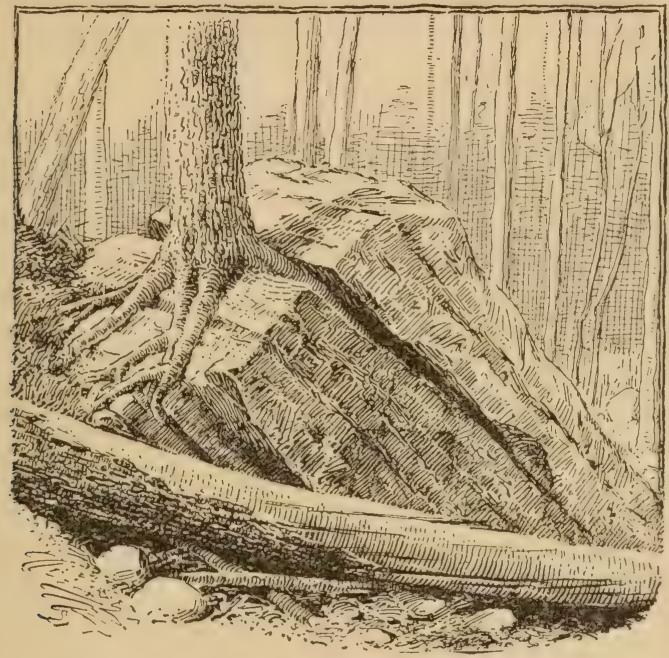

FIG. 5. - Trees ASSIST IN BREAKING ROCK

lying just under the surface. The soil of much of the black prairie land of Texas and other Southern States was formed in this way. The lime rock is only a few feet uncler the surface. White, grayish, or blue lime rock powdered up and mixed with humus, or rotting vegetable matter, always turns black. These soils, lying where they were formed, are sometimes called sedentary soits. Those moved by ice and water and wind are called transporterl soits. 


\section{QUESTIONS}

Why is it impossible to change the air so as to make it feed plints better? What can he done to the soil to make plants grow better? Is it often profitable to furnish plants extra water? Is it possible to work the land in a way to make the rainfall last longer? What is soil? What is soil made of? What do you call the upper part of the soil, and what the lower part? What makes the soil clarker in color than the subsoil? What do you eall rottiug vegetable matter in the soil? IIow deep do plows generally run? What is the name of the science that teaches us the past hisury of the earth? What was the first condition of the surface of the rarth? IIow did it become cooled? What effect did ice have in lrreaking up the rock of the earth's surface? Where is soil being marle at this time? What sort of plants first grew on the rocks, and what effect did they have? Describe how glaciers help make rock into soil. The soil marle by glaciers is callerl by what name? Explain how streams sort ont different kinds of soil. Besides water and ice, name any other means by which soil is moved and sorted out. Was the soil of the hack prairies of Texas, Mississippi, and Alabama transported, or is it lying where it was formed?

Experiment. - Ineat different kinrls of rock; pour water ou them while hot. Note how many crack and lreak and how many can be easily powdered up. Do this at recess or after school.

In winter notice how hanks of ditches, streams, etc., crumble down after a frepge. Make a little lime by burning chalk; mix it well in a hall of murl marle of stiff clay. Let it dry, keep it, and olserve it from day to day.

Stir a quart of clay luam soil violently in a bucket of water; let the water rest a second or two and pour the water off into another bucket and let it settle for an hour. Dry the settlings in both buckets and see what kind of soil you have in each. 


\section{CHAPTER IV}

\section{KINDS OF SOIL}

Sand, Clay, and Loam. - We generally know a sandy (1r clay soil when we see it. Sandy soils are made up of coarse particles of rock, and clay soils of very fine material, having searcely any grain at all. (Hay soils may be of any color, and are generally sticky. when wet. They are usually richer than sandy soils, but harder to work.

A mixture of sand and clay, especially when containing a good quantity of humus, is what is called a loam. Besides, we have clay loams and sandy loams. The loam soils nearly always drain well and are easy to work; they are usually richer than sandy soils and stand drought better.

Then we have limy soils, sometimes called calcareous sills. They are made of rotten lime rock. All the great black prairie belts in Texas, Mississippi, and Alahama are covered with calcareous soil. It is stiff and sticky when wet, but crumbles into little shotlike particles when dry. If you mix a little lime with a small ball of sticky clay and put it out to dry, it will crumble to powder when it dries. Limy soils are generally of great fertility. They often contain ten times as much plant food as sandy soils.

Arid and Semiarid Soils. - In much of West Texas and north to the Canadian line and west to the Rocky Moun- 
tains there is so little rainfall that the soils are callerl arid or semiarid. 'That means that they are not watered, on' only half watered.

These soils are generally loose and sandy in nature, but are very productive when watered. There is no such thing as a poor arid soil. Soils that have plenty of rain

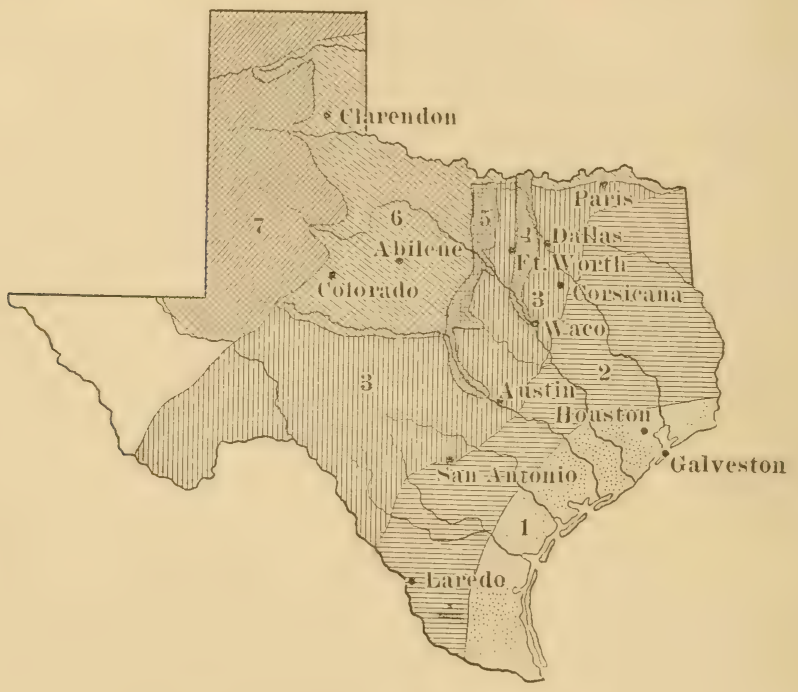

Fia. 6. - Soth Divisions of Texas

No. 1. Coast Prairie

" 2. Sandy and Clay Land mainly of the Timber Belt

" 3. Lime Land
No. 4. East Cross Timbers

"5. West Cross Timbers

"6. Red Lands

"7. Great Plains

are called humid. The reason that arid soils are so much richer than humid soils is that the latter have harl plant food washed, or leached, out of them all through the past ages. Chemical analysis shows that certain dry $\mathbf{I I}^{r}$ est 
Texas soils contain twenty times as much of some of the important elements of plant food as the pine-ivoods lands of East Texas contain. Wherever these dry lands are well irrigated, they become sources of great wealth.

Alkali Land. - Sometimes dry lands are so full of salts hurtful to crops that they are called alliali lands. Alkali lands never occur in humid climates, because the rain washes out the harmful compounds along with some of the useful elements of plant food.

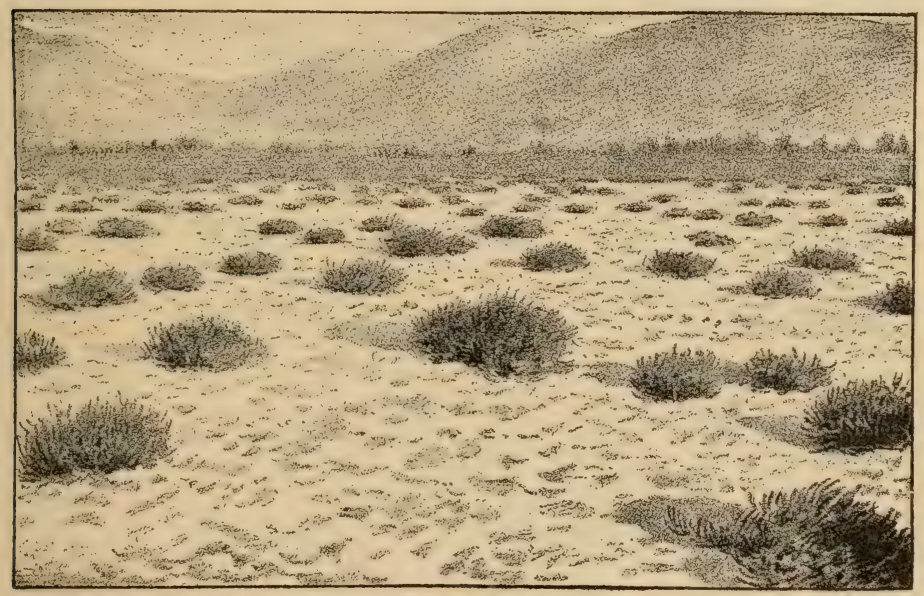

Fig. 7. - Alkali Land

By heavily irrigating alkali land after tile draining it, the excess of salts hurtful to crops is washed out of it, and it becomes very productive. Carbonate of soda in excess causes what is known as black alkali. Still other harmful compounds cause what is known as white alkali. 
Geological Formations. - Looking at the map, Figure 6, we find that the state of Texas is divided into several belts, according to the general types of soil in each belt.

Coast Prairies. - The coast prairies, occupying a strip of level land from thirty to sixty miles wide, are generally a clay or clay-loam soil, with a clay subsoil. Where the larger rivers such as the Brazos, Colorado, and Nueces enter the coastal plains, the soils are largely made up of the rich deposits from the streams. These soils are often very rich in lime, and richer also in the other elements of plant food than the rest of the coast prairies. As the coastal prairies reach farther west and get more and more into the dry belt, the soil becomes naturally richer; that is, it contains larger amounts of plant food. So is the soil deposited by the Brazos, Colorado, and Nueces rivers richer than that deposited by the Trinity and Sabine, because the former three rivers rise and flow through drier and naturally more fertile sections than the latter two. The Trinity flows through rich black land, and its deposits are richer than those of the Sabine.

Timber Belt. - North of the coast prairies lies an immense timber belt. This includes the long-leaf and shortleaf pine areas of East Texas and the other Southern States, and a broad strip of post-oak land extending far southwest toward the Rio Grande. These areas are rolling lands, generally made up of sand and clay. Here, as in almost all humid sections, the subsoil generally contains a larger proportion of clay than the top soil.

In the eastern part of this belt, where pine timber is abundant, the land is often very sandy and seldom 
stiffer than clay loam. These pine lands are naturally poor in plant food; but they drain well, are warm, hold moisture well, and respond remarkably to fertilizers. By the help of fertilizers these thin lands produce fine crops of fruits, vegetables, tobacco, corn, and cotton.

The large area of post-oak land mentioned above also seems to need commercial fertilizers in orter to give the best results.

There are many small patches of lime land cropping out in the timber belts describerl, but the country has not been mapped earefully enough for us to know their extent. There is a considerable area of lime prairies comprising parts of Washington, Lee, and other counties, just west of the Brazos River.

Calcareous Soils. - Occupying an immense area in the central part of Texas are the cretaceous, or lime, lands of the state. This belt was, even before it was cultivated, generally without timber, and hence it is called prairie. Lime lands are usually so rich in plant food that commercial fertilizers cannot be profitably used on them. If such lands become less productive, a crop or two of clover, grass, peas, or some other crop that will add humus to it and loosen it up, will make it generally productive again.

It never injures strong lime land to plow it wet, because the lime causes it to crumble into powder, as has already been explained.

Buckshot Land. - Much of the stiff land in the river bottoms is of this character; when wet it is stiff and sticky, but when dry it crumbles. This kind of land in 
the bottoms is often called "buckshot" land, because the (rumbs it breaks into are somewhat like shot.

Grand Prairie. - The western part of the lime prairies, known as the Fort Worth Prairie, or Grand Prairie, has not so deep or so black a soil as the eastern part, or Black Prairie. The lime rock of the Grand P'rairie is sounder and harder, and decays more slowly. Hence, the decayed rock, or soil, is thimner, and often has less humus, and is

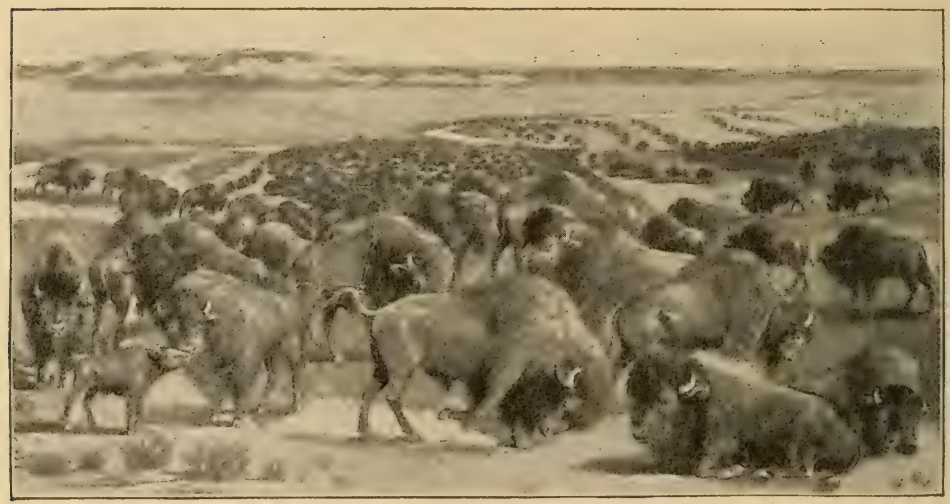

Fig. 8. - Former Inhabitants of the Plains

not so dark in color. The Grand Prairie is more elevated, more rolling, and consequently more subject to wash. Much of its soil, formed through the ages past from the weathering and crumbling of the rock, has been washed off into the streams, and much of it into the sea.

Red Lands. - North and west of the great Black and Grand Prairie belts, and between these lime prairies and the Crreat Plains, lies a large area of soils generally red or brown in color, so far as the writer has seen, and composed 
mostly of sinds, clays, and loams. This region was also mostly treeless. This area also includes light, thin soils with occasional sections rich in lime, such as the gypsum deposits. 'This section scarcely contains such great stores of plant food as the black prairies do, but it is generally more fertile than the East 'Texas or South Texas timbered lands. Lying west and north, these lands are naturally

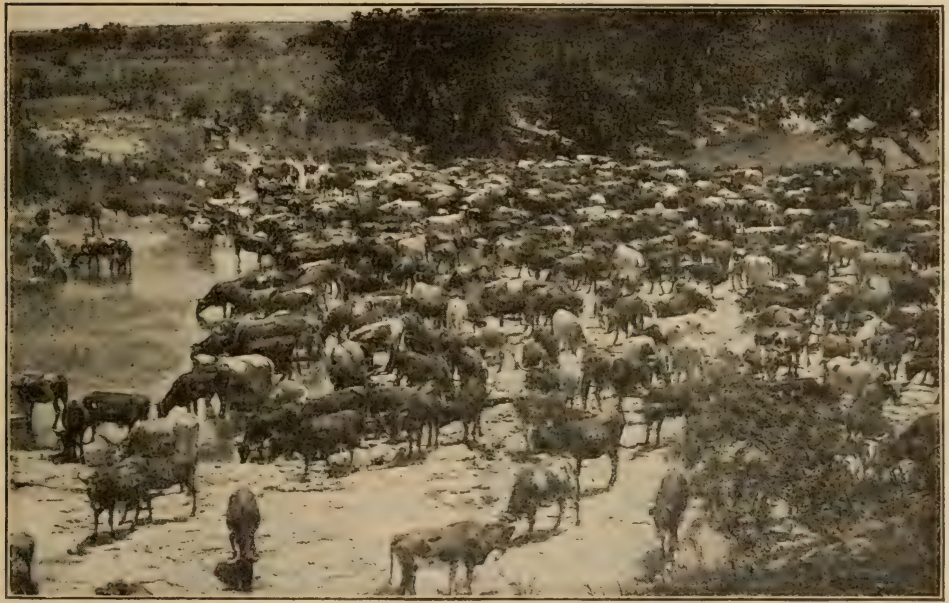

Fig. 9. - Present-day Scene on the Plains

more fertile than the lands farther east and south formed of a similar kind of rock. The influence of rainfall has already been explained. It has been also well proved that the lands farther north do not wear and lose their fertility as the more southern soils do. As the soils of northern climates are frozen more of the time, their plant food is locked up so that it camnot waste away. It rains little as far west as West Texas in winter, when crops are not 
growing. In East Texas and the other Southern States it rains much in winter, when erops are not growing, and hence the land is leached and impoverished.

Chemical analysis has frequently shown that a clay loam soil in W isconsin, for instance, contains several times as much lime, phosphoric acid, potash, and nitrogen in a form to be used by crops, as a clay loam in Mississippi. That is, the soluble plant food in the Mississippi soil is dissolving and washing away throughout the warm, wet winter, while in IVisconsin the soil is locked up in ice for perhaps six months. The Mississippi land should grow a restorative crop in winter to keep it from becoming poor.

Red Fruit, Truck, and Tobacco Soils. - Much of the East Texas timber belt has sandy loam soil varying from light gray to a bright red in color. The red color denotes iron compounds and good natural drainage. This area produces the fine wrapper and filler tobaceo of Nacogdoches and Palestine, the tomatoes, potatoes, and other truck crops of Jacksonville, Troupe, Henderson, Athens, Tyler, and other points. This same area is becoming one of the great peach-growing sections of the South.

The Great Plains. - Lying still farther west, northwest, and southwest of the last area described are the Great Plains. The Plains comprise a large area of level land, ranging from about 4000 feet high in the northwest to about 2500 feet in the southeast. The Plains of Texas include most of the Panhandle and extend southwest to the Pecos River. The soils of these plains are said by geologists to have been deposited in an ancient fresh-water 
lake. The soils vary from light sands to dense, stiff clays. In color they vary from black to red. The Plains are so bare of timber, except in sheltered canyons, that one might ride all day and never find a riding switch. This treeless condition is probably due to ammual fires that swept over the country. The Plains extend north to Canadia and west to the foothills of the Rocky Mountains.

The soils are rich, and as the people have gradually learned to cultivate them so as to conserve the twenty or more inches of anmual rainfall of the eastern part of the Plains, farming has made splendid progress. Fine crops of kafir, milo, sorghum, corn, wheat, oats, melons, ete., are readily grown. The land is still mostly used for grazing, but it is being rapidly cut up into small tracts for farms.

West of the Pecos River. - This section is generally rather mountainous and rough, but it contains many fertile valleys. With irrigation these are, of course, very productive. So far there has been no large development of farming in this region, except in the Pecos and Rio Grande and other river valleys. In the more elevated mountain valleys of this region apples and grapes thrive wonderfully under irrigation. Some day this region will rival any other part of the world in the procluction of these and other fruits.

Cross Timbers. - It will be noticed from the map that the timber area of Texas extends up Red River far west of Fort Worth, and one narrow belt comes southward between Dallas and Fort Worth to Waco, and the other extends from considerably west of Fort Worth, and reaches nearly 
to Austin. These are called the East and West C'ross Timbers. The land in these belts is sandy, and resembles, in every essential particular, the large post-oak belt, in South Texas, except that it is generally more sandy. Like the latter, the land in the cross-timbers sections will no doubt respond profitably to the use of commercial fertilizers. These lands produce fine fruits, vegetables, and potatoes, as well as general crops. The cross-timbers h.mds were at one time considered almost worthless, but they are now held in high esteem.

Soils of the Cotton States. - Figure 10 shows the different soils of the whole cotton belt as mapped by the Department of Agriculture. It will be seen that the pine flats and pine hills appear in all states touching the sea. The lands marked "oak" also appear in most of them. These lands are often spoken of as oak, hickory, and short-leaf pine lands, as all these growths generally appear except in the western part of this area in Texas, where the short-leaf pine disappears. Black prairies occur only in Texas, Mississippi, Alabama, and a little corner in Arkansas. There are also considerable areas of limeprairie in Oklahoma not shown on this map. The deep Red Lands appear only in Arkansas, Oklahoma, and Tennessee, and the Piedmont includes the more elevated regions of Alabama, Georgia, and the Carolinas. Alluvial lands are usually situated along the larger rivers, especially the Mississippi. The two classes of Pine lands, the Oak, the Piedmont, and Sand Hills, are largely fertilized with eommercial fertilizers, especially in the older states. These lands are not of high natural fertility, but 


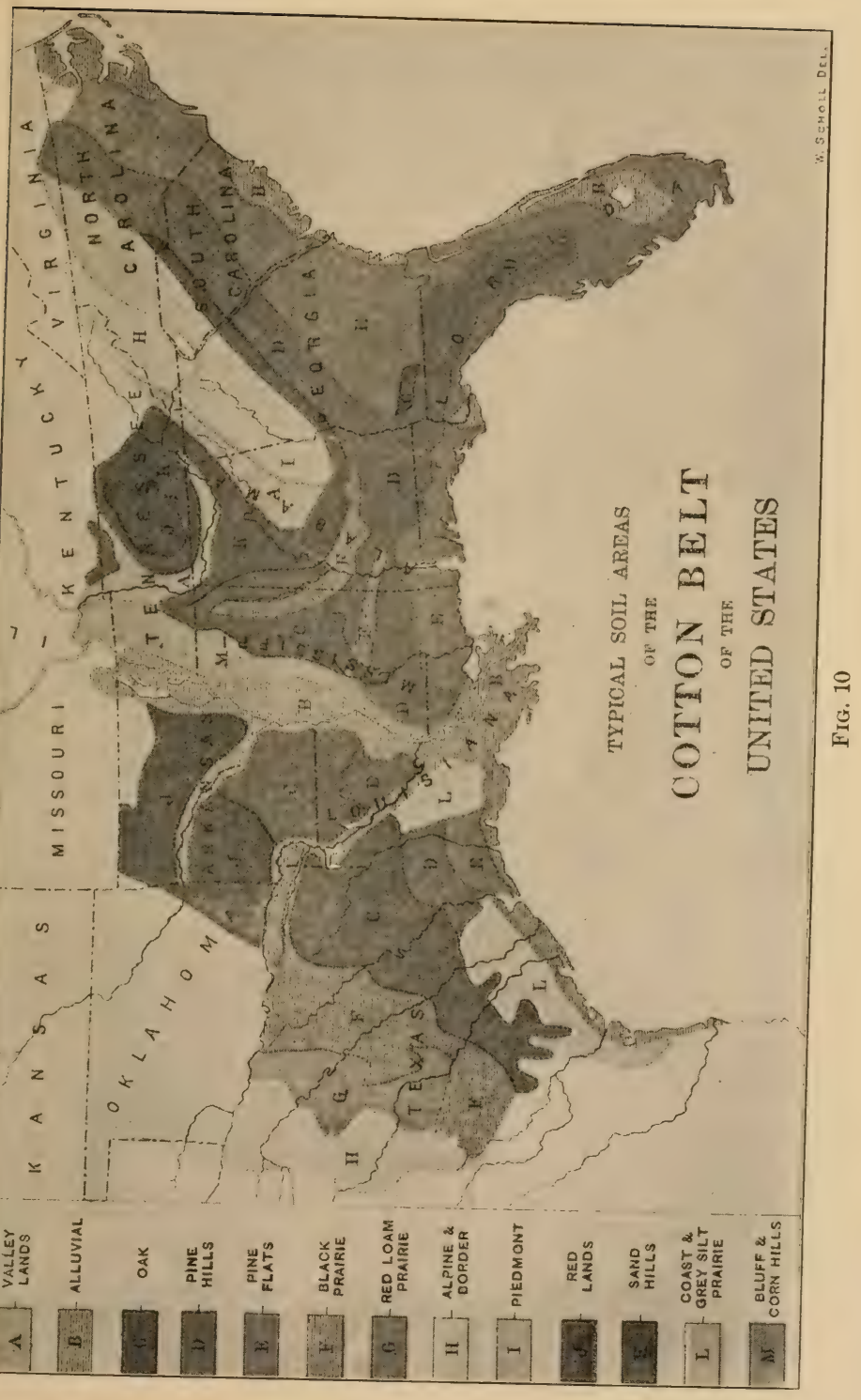


are very susceptible to high improvement. These and the Red Lands are largely of the same nature. In fact, most of the agricultural land of the earth is mate up of sands, clays, and loams not very rich in lime. Where the sands and clays are mixerl, making loams, the soil drains well, warms up early, works easily, holds moisture well, pays for fertilizing, and, although not naturally rich, makes profitable farming and gardening land the world over.

Light and Heavy Soils. - Sandy land is often called light land, although it may weigh, when dry, one hundred pounds to a cubic foot, while clay land weighing, say, seventy-five pounds to a cubic foot, is called heavy land. Sandy land is called light because it is easy to work. Clay land is sticky and tough, and is called heavy because it is hard to work.

Light sandy lands are warm and good for early truck crops, watermelons, ete., while heavy clay lands are gool for grasses, wheat, rice, and other crojss. Corn, cotton, oats, sorghum, and many other crops do equally well on various kinds of soil, if the soils be equally rich and in suitable condition.

\section{QUESTIONS}

What is the difference hetween sandy and clay soils? Which is generally richer, sandy soil or clay soil? What do we call a mixture of sand and clay? What do you understand by calcareous soils? Where do you find these? What makes such soil crumble when it dries? Are these soils generally fertile? Define arid, semiarid, and humid soils. Why are arid and semiarid soils generally richer than humid soils? What are alkali lands? What can he done to get rirl 
of alkali? Draw a map of Texas and mark the different geological divisions. Describe the coast prairies. Will the soils be richer along the Brazos River where it flows through the coast pratries than the other coast prairie land? Explain why. What varieties of lamls are there in the main timber belts of Texas? What character of land is found in the pine timber belt of the Sonthern States? Under what circumstances are pine lands good farming lands? What do you understand by buckshot land? What is the difference between the eastern part of the Texas lime lands and the western part? I) (scribe the red land areas of Texas. Why is land North and West naturally richer than the land Sonth and East? Describe the Great Plains. What kind of soils are found on the Great Plains? What kind of land is found in cross-limber's areas of Texas? Why is sandy land called light land? 


\section{CHAP'TER V}

\section{RAINFALL AND PRODUCTIONS OF TEXAS}

Floulis 11 is a map of the State of Texas, showing the amomnt of amnual rainfall in the lifferent belts. In cxtreme Last Texas fifty or more inches fall on the average during the year; in another broad belt, forty inches or more; in another rather narrow strip west, thirty inches; then in a very broad belt extending west of the 101st Meridian, twenty or more inches; west of this ten to twenty inches fall. These lines of rainfall curve eastward as we go north to the Canadian line. But northern latitudes demand less rain than southern latitudes, be("aluse of shorter summers, cooler temperatures, and less raupration. Western Nebraska should make as good (rops on fifteen inches of rain as Texas can on twenty inches.

Fortunately, in West Texas and the semiarid belt generally, where rainfall is light, a large proportion of the total falls in the spring and summer, when it is most likely to be needed. In kast Texas and farther east, much of the rain falls in winter.

These rain belts go far toward determining the kinds of arops that can be grown, and will be referred to frequently.

Elevation and Production. - Texas varies in elevation from sea level to about five thousand feet, not considering 
the mountain peaks. Elevation influences climate quite as much as latitude does. A small portion of Texas about the mouth of the Rio Grande is truly tropical. All the coast country is subtropical. Here we find the

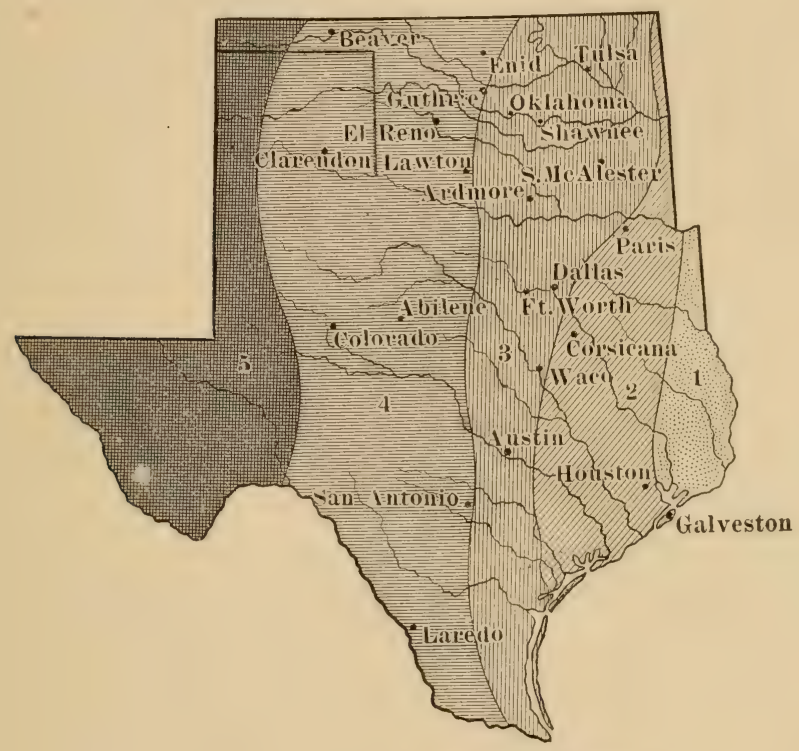

Fig. 11.-Ratnfall Map of Texas

No. 1. 50 inches and over

“. 2. 40 to 50 inches

.6 3. 30 to 40 inches
No. 4.20 to 30 inches

" 5. 10 to 20 inches

sugar cane, rice, banmas, and oranges, while the western part of the Panhandle has exactly such a climate as grows sugar beets to perfection in Colorado and Michigan. It is mainly the elevation of the Panhandle that gives it the temperature suitable for the sugar beet. 
Between the extremes, Texas has fine climates for wheat, wats, corn, cotton, and a great variety of other crops.

Wheat will thrive farther west than corn, because it requires less rain. Still farther west sorghum, kafir corn, milo-maize, etc., are grown, largely because the land is so dry that Indian corn is not a certain crop. ('otton flourishes in both wet and dry sections if there is warmth enough. Far to the west, alfalfa, when irrigated, revels in the abundance of plant food and the fine mellow, porous soil. Of course, the dry, rich soils of the Pecos, the Rio Grande, the Arkansas, and many other valleys, when irrigated, grow a great variety of crops to perfection.

\section{QUESTIONS}

Draw a map of Texas and show the different rain belts. Alout how much rain falls in each belt? Iow many different kinds of climate are found in Texas? What effect does elevation above sea level have on climate? What effect does climate have on corn production? What crops do well where it is too dry for Indian corn? 


\section{CHAP'TER VI}

\section{CHEMISTRY OF SOIL AND OF PLANTS}

The Elements of Matter. - We have several times referred to elements. An element is the simplest form of matter. Iron and gold are elements. Oxygen is an element. Elements may be called the A B C of matter. Just as twenty-six letters may be combined so as to form many thousands of words, so less than one hundred elements unite in various ways to form every substance in existence. Some of these elements are solids, one is a liquid, and some are gases. Iron rust is not an element. It is a substance formed by the union of iron and oxygen. The chemist can separate the iron rust into its elements and thus obtain pure oxygen and metallic iron again. Water is a substance formed by the union of oxygen and hydrogen in the proportion of two parts, by volume, of hydrogen to one of oxygen. The water thus formed may be separated into these gases again. Such a union of two or more elements is called a chemical compound.

Chemical and Physical Changes. - When water evaporates, or when it forms steam, it is not then separated into oxygen and hydrogen, but merely divided into fine particles of water, and each particle floats in the air. This is a physical change in the water. The formation of ice 
is also a physical change. Filing iron into dust produces only a physical change, just as breaking a piece of iron in two. Powder some chalk into dust, and you effect only a physical or mechanical change. Each particle of dust is as pure chalk as that you had before. If you pour some strong vinegar on the chalk, it will boil, get hot, and consume the chalk, forming new compounds in no way like chalk or vinegar. If we eut wood, a physical or mechanical change is produced. If wood burns, a chemical change is produced. When wood burns, another chemical element, the oxygen of the air, comes in and unites with the elements of the wood, and additional compounds are formed, all of which are entirely different from the original wood.

Chemical changes completely alter the substances. A union of oxygen and hydrogen gases forms water, a liquid. Two gases may form a solid when united, or they may form a liquir, or another gas. Two substances. poisonous in themselves, may unite and form a harmless compound; or two substances, harmless in themselves. may form a deadly poison. Common salt is made of a metal called sodium and a gas called chlorine; both of these elements are poisonous before uniting.

Plants as Chemists. - Plants are skillful chemists. Out of water and carbon plants manufacture sugar, oil, woody fiber, etc. From carbon and water, with a little nitrogen, phosphorus, and sulphur from the soil, plants produce the most complicater compounds found in plant anil animal bodies.

Elements found in Plants. - When plants are analyzed 
(that is, separated into their elements), about fifteen elements are found in them, as follows:-

$\begin{array}{llll}\text { carbon } & \text { sulphur } & \text { potassium } & \text { aluminum } \\ \text { hydrogen } & \text { phosphorus } & \text { sodium } & \text { silicon } \\ \text { oxygen } & \text { magnesium } & \text { iron } & \text { chlorine } \\ \text { nitrogen } & \text { calcium } & \text { manganese } & \end{array}$

The sodium, manganese, aluminum, silicon, and chlorine are perhaps not necessary for plant growth, but plants will not grow in the absence of any one of the other ten elements. All plants use the same elements: but they do not use them in the same proportions.

Where Elements of Plants come From.-.. Of these ten elements necessary for plants, the air supplies the carbon; the water the hydrogen and oxygen, and the soil all the others. Some plants, however, can get nitrogen from the air circulating in the soil.

Sunshine. - The sumshine adds nothing to build up the plants. Like a fire in the furnace of a boiler, it furnishes heat that causes the work to be done. The warmth of the sun causes many chemical changes to take place in the soil and in the plant. Without the warmth and light of the sun nothing could grow, nothing could live. When coal burns, it gives out heat. The energy that produces the heat in the coal was supplierl to the trees perhaps millions of years ago by the heat and light of the sun, and these trees afterward formed the great coal beds. A great waterfall like Niagara produces energy to run railroad trains and factories, and to light cities, but the heatenergy of the sun raiserl the water from the sea and put 
in motion the wind that carried it to the watershed of the river ; so that, after all, the work of the water was made jossible by the work of the sum, the great somrce of all work.

Abundance of Most Elements. - (1) ty two or three of the elements of plant forl fumisherl hy the soil are ever so searce as to prevent the normal growth of plants. Phosphorus and nitrogen are most often swarce. In much of the sandy and loamy lands of the South neither of these elements exists in sufficient quantities to raise good erops. Hence fertilizers are userl. Potassinm also may be searce in very sandy or very por lands. Lime may occasionally be needed in fertilizers, but not often.

Most of the value of commercial fertilizers or barnyar:l manure is due to the nitrogen, phosplorus, and potassium which they contain. A wagon load of barnyard manure may contain no more than thirty poums of these valuable elements, but even this amount gives it high value.

Fertilizing Elements found Combined. - These elements are always united with other elements in soils and fertilizers. Alout four-fifths of the air is pure nitrogen, but in the gaseons form it is of no use to most plants. But ('ombined with oxygen and sodium, it forms sodium nitrate, a solid substance soluble in water. In this compound it is a splendid fertilizer.

Phosphorus burns in air, and hence camnot be used in the pure state. Combined with oxygen, calcium, and water to form calcium phosphate, an important constituent of bones, it is easily handled and is an excellent fertilizer. Bones, which contain about twenty-five per 
cent phosphoric acid in this form, are fine fertilizers. Potassium will burn in water or air, and is consequently not found pure in nature. Combined with oxygen and sulphur into potassium sulphate, or with chlorine into potassium chloride, it is easily handled as a fertilizer. Wood ashes are rich in potash (one of the substances that make soap when mixed with grease), and mainly for this reason ashes may be good fertilizers; they also contain some phosphoric acid and lime. Fertilizer's will be discussed in a later chapter.

\section{QUESTIONS}

What is a chemical element? (ive an example of an element. Ahout how many elements are there? What substances do the differmit elements make ul? What is water made of? What are the elements of iron rust? Are iron rust and water elements or comprounds? Can water be separated into its elements? If water is frozen into ice, is that a chemical or physical change? If you powder chalk, is that a chemical or physical change? If you pour vinegar (nil powdered chalk, what sort of a change takes place? If wood burns, what sort of a change is produced? Which makes the most complete change in substances, chemical or physical changes? What do plants nse for making sugar, starch, and oil? Can chemists produce sugar from these substances? Can plants produce still other substances that chemists cannot make? Ilow many elements are found in plants when they are analyzed? Name some of the more important ones. Do all plants need the same elements for growth? Do all plants use the same elements in the same proportion? What effect iloes the sun have on the growth of plants? Where did the heat of lurning coal first come from? Explain what the sun had to do with making a waterfall. How many elements sometimes get scarce in the land so that crops cannot grow well? What do we do to supply these scarce elements? Name the two elements that are most of ten scarce. What other two occasionally are not present in sufficient 
quantity? Why do we not find phosphorus pure? What fertilizer ingredient is found in bones?

Experiment. - Iteat chalk and see if you cam make lime. Sili a good quantity of this lime in water and let it stand awhile. P'our the clear liquid off and blow your breath through it, using a tulu or hollow straw. Note the milky appearance of the liquid. Sese if you can settle some of this chalk and collect it.

Put some zine in a little bottle of strong hydrochloric, or muriatic. acid, which you can get at the drug store. See if gas given off at the mouth of the bottle will burn. If there is enough of it and the neck of the bottle is small enough, it will burn. Ijeing hydrogen gas, it will form water when it burns by uniting with the oxygen of the air. Bucareful in this experiment, as a small explosion may occur.

Heat a little ammonia: hold a rod wet with hydrochlorie acirl in the gases rising and note result. 


\section{CHAPTER VII}

\section{THE PHYSICS OF THE SOIL: STORAGE OF WATER}

Soil a Storehouse for Plant Food. - The soil made up, as we have seen, of ground-up rock mixed with humus, or decaying vegetable and animal matter, is a storehouse of plant food. Even moderately good land will have in a foot of depth enough nitrogen, phosphoric acid, and potash to supply crops for two or three hundred years or more, but the roots of most plants feed to a depth of four or five feet. Since plants can use only soluble matter, and since plant food becomes soluble very slowly, lands having a large quantity of plant food may sometimes become unproductive and need fertilizing.

Soil a Storehouse for Water. - The soil stores rain-Ivater and gradually gives it up to the plants. Sometimes soils are known to hold water enough to nourish plants during a six months' drought. Ordinarily erops begin to suffer when they go without rain for three weeks or a month. Crops need an immense amount of water. A mature corn stalk of large size may be sairl to have used during its lifetime about two barrels of water. The production of one pound of dry hay, or other dry plant body, requires the use of about 400 pounds of water. Most of this water is evaporated from the leaves.

Water-holding Power of Soils. - ('lay soil may often hold forty per cent or fifty per cent of its own dry weight 
of water and not be wet enough to allow any water to drip from it. We call this water soil-moisture. If a cubie foot of dry clay soil weighs 75 pounds, it will hold 30 to $: 37.5$ pounds of water, and will weigh 105 to 112.5 pounds when thoronghly moist. A sandy soil will barely hold twenty per cent of its weight of water. A cubic foot of dry, sandy soil weighing 100 pounds will hold 20 pounds of water, and will, therefore, weigh 1:0 pounds when thoronghly wet. Dry humus will sometimes hold twice its weight of water. Hence, if soil has plenty of humus in it, it will hold more water and stand drought better. Such is the case with new lands, or old land after peas or other restorative ('rops have been grown on it; or land that has been in pasture a few years.

A clay soil may hold in a depth of four feet ten inches more water than does sandy soil. 'Ten inches of water' would be equal to ten hig rains. It would be supposed that clay soils would always stand drought well, and sandy soils would always suffer worst from drought. This is not always so. Sandy soils generally suffer more than clay soils, but sometimes the clay soils suffer more. Sandy land will come nearer giving up all the water in it than clay land will. Crops ean use the water from the sand until the supply gets as low as five per cent. In clay, plants can harlly live after the supply of water gets below twelve or fifteen per cent.

Clay is often so wet in early spring that roots ammot go deep, and when a drought comes, the crops burn "up. Clay land is quite sticky when wet, and if plowerl wet 
and dried suddenly by the sun, will be clodily and very hard to get into good condition. When very dry, it shrinks and cracks, thus breaking plant roots and cansing the plints to suffer severely from drought.

A loamy soil with a good percentage of humus will generally stand drought better than claty or sand. Loams also drain nearly as well as sambl and can be worked almost as easily. A good loam contains nearly all the advantages and but few of the disadvantages of sandy and clay soils.

\section{Kinds of Water in the} Soil. - In a moist soil a thin film, or sheet, of water surrounds each grain, but there are small

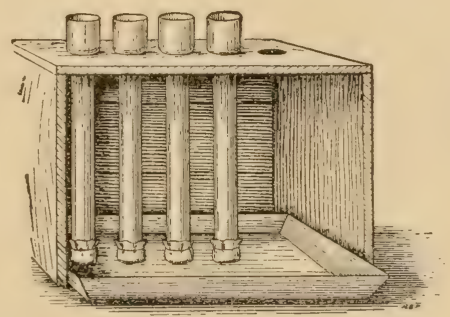

Fig. 12. - Showing Capillari ACTION OF SOILS

spaces between the grains. That is, the soil is porous and will arlmit air. The water held as moisture is called capillary water. It moves about in the soil by capillary action. In a dry time water rises in this way from below to supply plants. I limp wick raises oil by the same means. If you will insert some little glass tubes in a vessel of water, you will see the water rise in the tubes. The smaller the tubes, the higher the water will rise. This is capillary action. Capillary water, or moisture, is the kind of water most beneficial to erops. As smaller glass tubes will cause water to rise higher than larger ones, so a soil with small grains, like clay or clay loam, having smaller spaces between the grains, will cause 
Water to rise higher in time of drought than coarse sandy soil will. But since the sandy soil has large grains and large tubes, or pores, between the grains, calpillary water will move faster in sandy soil than in clay soil. We have all noticed that rain water sinks into sandy soil faster than it does into a clay soil.

Ground Water. - If we dig deep down into the soil, say thirty or forty feet, we find standing water, as in wolls. This is called ground water, or the unter table. Sometimes we fiml gromel water within a foot of the surface. When the pore spaces of the soil are thus filled with water, air camnot enter, and roots of most plants camnot grow. Hence the necessity of draining the land. Fround water may remain near the surface for a short time without doing much harm. In most soils, erops would never suffer from drought if ground water remained about four feet from the surface. Enough of the ground water would be drawn up by capillary action to moisten the soil and supply the crops. But when the ground water is thirty or forty feet reep, it probably roes not greatly benefit the crops.

Hygroscopic Water. - I)ust, apparently dry, contitins some water. as may he proved by heating a weighed quantity of it to the boiling temperature of water, and then weighing it again and noting the difference in weight. This is alled hy!roseopic uater. IIygrosenpic water is of little or no value to erops, as it can liardly be used by most plants. Iay, corn, flour, cotton-seed meal, and most other dry substances contain ahout ten per cent of moisture that may be driven off by heat, but they 
will regain the same amount of moisture from the air when they get cold.

Importance of Water.--For each poumd of soil food used by arops from 4000 to 10.0000 pounds of water are needed, most of it being evaporated from the plant leaves. Some of this water is evaporated from the surface of the ground, and a little is used to help build up the plant. It can be seen from this how very important it is to supply plenty of water either by irrigation or by so working the land as to make it hold and furnish the (rops the greatest amount of rain water. Water is not only an important food for erops, but it is the life blood of plants, as it carries all foor into and through the plants.

Green or Succulent Plants. -- Every green plant, or vegetable, is largely composed of water. (rreen grass, corn. sorghum, etc., contain seventy-five to eighty-five per cent of water. Melons, strawberries, cucumbers, and many other fruits and regetables contain ninety per cent or more of water; Irish potatoes, eighty per cent, and sweet potatoes, seventy per cent. Hay, even when dry enough to stack or house, contains thirty to thirty-five per cent of water. You have noticed corn and sorghum wilt and (lroop on a hot afternoon; this is because the water is evalorating from the leaves faster than the roots can take it in from the soil. At night evaporation is not so fast, and the roots catch up with their work.

Wet Soils too Cold. - In speaking of water for crops, we mean water in the form of eapillary moisture. A soil full of standing water will neither water nor feed most wops 
to the hest advantage, because it is too cold. All soils in wr climate are too cold in early spring, and crops cannot grow until the ground is warmed by the heat of the sum. Even seerls will not sprout or germinate until the gromul has heen somewhat warmed. It reguires five times as much

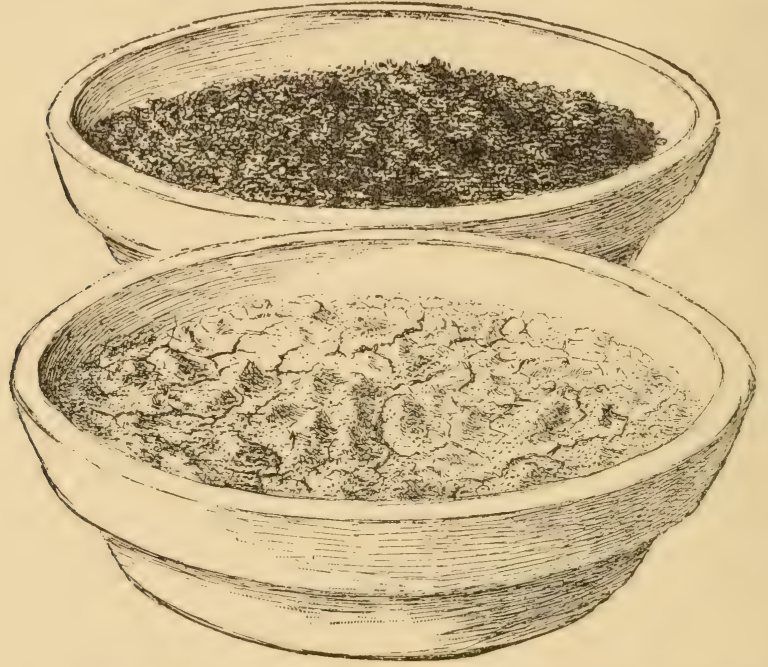

Fiti. 13. - Stirning Soll when Wet and when in Right Conidtion

lieat to warm a pound of water one regree as it does to warm a pomnd of moist, sandy soil one degree. 'Therefore, if a soil is full of water, it talies a long time for the sum to warm it 11]). Hence, land in sections where winter rainfall is heavy should he handled in a way to get riol of water before the spring.

Evaporation produces Cold. - Igain youl have noticerl that wet clothes in windy weather make you very colli. The water ('vaporates. or dries off. and takes m) the heat 
from your body. That makes you cold. So a soil full of water has been found to lose from its surface by evaporation several times as much water as a soil that contains only the proper amount of moisture. Therefore the wet soil will be much colder than a moist soil.

A very wet soil has sometimes been observed to evalunrate an inch depth of water a week more than a moist soil. The heat required to evaporate this amount of water from an acre of land would melt tion tons of ice. The cold produced by evaporating this quantity of water would convert over 500 tons of well-water into ice. Hence it is that a thermometer stuck into a very wet soil often shows a temperature 10 degrees lower than it does when put into a well-drained soil of the same kind. It need not be wondered at, then, that corn and cotton will fresquently remain small and yellow on undrained soil. ('or'm and cotton will not grow at 50 degrees Fahrenheit, hut they grow well at b0 degrees. A plant may stand with its roots bathed in water and be able to use but little of it. In fact, the large amount of water in the soil, and the evaporation from it, may make the plant so cold that its sap will not flow. To prevent evaporation of moisture in summer and make erops stand drought, land is cultivaterl. The compact condition of the soil is broken so moisture camnot be drawn up to the surface. Cultivating three inches deep saves the moisture better than a less depth.

Least Amount of Water for Good Crops. - It has heen found that about the least amount of water required to make crops is four inches in depth for each ton of dry material in the crop. On the (ireat Plains, where aloout 
1:2 or 15 inches of rain wan generally be counted on during the growing season, the land may be so worked that it will make three or four tons of hay to the acre; and if the rainfall were conserved in the hest manner, probably 5) or 60 bushels of corn conld be made to the acre. To furnish water to plants we want a moist soil but not a wet one.

Drainage is such an important question that it will be discussed in a separate chapter, as will also the subject of cultivation as a means of saving moisture.

Dark-colored Soils Warm. - Of soils of the same composition and equally well drained, those that are dark in color will get warm earlier in the spring. You have noticed that black clothes are much warmer in the sunshine than light-colored clothes. 'The dark-colored clothing allows the sun's heat to penetrate and reach the body, while white clothing reflects the heat. So dark soils absorb the sun's heat more readily than do light-colored soils.

\section{QUESTIONS}

Where is the great storehouse of plant food? Suppose all the nitrosen. phosphoric acid, and potash in the lant conld be used by crops. would the land make very many erops? Why do lands become exhausted? How is water for plants kept over from one rain to another? Ifow long do plants sometimes do withont rain? IIow long can most field erops do without rain and not suffer? How much water will a lig corn stalk use during its lifetime? To produce a pound of dry hay. how much water must the plants use? Which will hold the most water, elay land or sandy land? Why will plenty of humus in the land make it hold water hetter? Which will give up its water to plants most completely, clay land or sandy land? Why will clay land not alway stand dronght hetter than sandy land? Explain what is meant 
by capillary water in the soil. What do you understand by the groumd water of the soil? IIow near the surface does the ground water. have to come to be harmful? How is ground water got rid of"? Explain hygroscopic water. IIow conld you compare the water plants use to the blood in our bodies? What is a succulent plant? How much of watermelons and strawberries is water? How much more heat will it take to warm a pound of water than a pound of soil? What other reason is there for wet soil to be cold? To evaporate an inch of water from an acre would use up how much heat? How much higher temperature can often be found in drained than in undrainerl soil? About how many inches of rain are required to make a ton of dry crop on an acre? Why are dark-colored soils warmer than lightcolored soils?

Experiment. - (irow a stalk of anm or other vigorous plant in a hox of soil at the schoolhouse or at home. Cover the top of the suil with a piece of blanket or some material to see that water cammot eraporate from the surface. Weigh box and contents from day to day, and note losses in weight, which will represent evaporation from the corn leaves. Fill lamp chimneys as shown in Fig. 12 with different kinds of dry soil. Tie cloth over each and immerse ends in pan of water and watch rise of capillary water in each.

Grow corn or other plants in cans with no drainage holes, and in cans with holes in the bottom. Water both liberally and note results.

Weigh potatoes, green grass, fruits, etc. Slice and dry them. Note losses and calculate percentage of water originally contained.

Weigh different kinds of well-dried soil after being put into pots. Wet them and let excess of water drip as long as it will. Then weigh again and note percentage and amomnt of water each kind holds.

Keep one box of soil excessively wet for some days and another box about right for growing plants. Keep them in the sun. Insert a thermometer three inches deep in each soil at midday and at 8 o'clock in the morning and note differences. Allow a crust to form on two boxes or pots of soil. Spread an inch layer of coarse dry sand on one. Weigh each from day to day and see which one loses moisture most rapidly.

All of the above are suitable school exercises. 


\section{CHAPTER · VIII}

\section{BACTERIA, OR GERII LIFE}

Work of Bacteria. - As is well known, little forms of life. plant and animal, too small to be seen except with a powerful microscope, play an important part in nature's processes. The souring of milk is caused by millions of
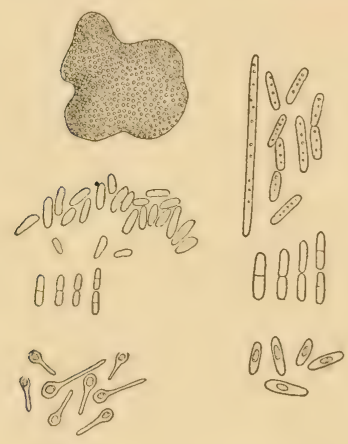

Fig. 14. - Different Bacteria. greatly Maginied

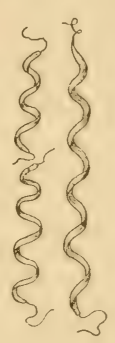

little living beings. The decay of fruit and the spoiling of meat are also caused by minute forms of plant life. Some kinds of bacterial life bring disease, and doubtless other kinds assist us to get well. It is entirely likely that we have more friends than enemies among these little beings, and withont them we could not live long. Only a year (1) two ago the French people tonk a vote on whom they regarded the greatest man that ever lived. A man named Pasteur was voted first, and Napoleon stood seventh. Pasterr's fame comes from his stuly of microscopic life. He learned to prevent and cure by inoculation human and animal plagues. IIe learned to prevent charbon and rinderpest of eattle and to cure hydrophobia of man. 
Influence on Industries. - Putting up fruit and sirup in cans is merely heating and killing the germ life in the material to be camnerl, and then sealing it up so the air cannot enter and bring nore germs into it. Meats, milk, vegetables, fruits, and most of the products likely to spoil may be preserved in this way. In making bread, wine, vinegar, alcohol, cheese, butter, and in many other inclustrial processes of the liousehold, the farm, and the factory, we are directly dependent on our little servants, the bacteria.

Effects on Soils and Manures. - It has long been linown that the bacteria play an important part in making soils productive, and in bringing about changes in animal manures. The organic matter, the remains of plant and animal bodies, in the soil, rots because it is attacked and eaten by myriads of microscopic beings. As this organic matter decays, it furnishes plant food to the growing crop. Nany other chemical changes that take place in the land are helperl or hindered in the same way. Barnyard manure is full of germ life. It has often been noticed that manure loses half its value in six months' time. Certain bacteria attack it, and convert its nitrogen into nitric acid, which washes away in the rain water, or into (arlonate of ammonia, which escapes into the air. The odor coming from stables is often caused by escaping carbonate of ammonia.

The best way to prevent germ life from destroying so much of the value of manure is to keep the manure well packed. An experiment in stall-feeding steers, at the Pennsylvania Experiment Station many years ago, 
showed that when the manure remained in the stable many months and became thoroughly packed, only about five or six per cent of the plant food was lost. When manure

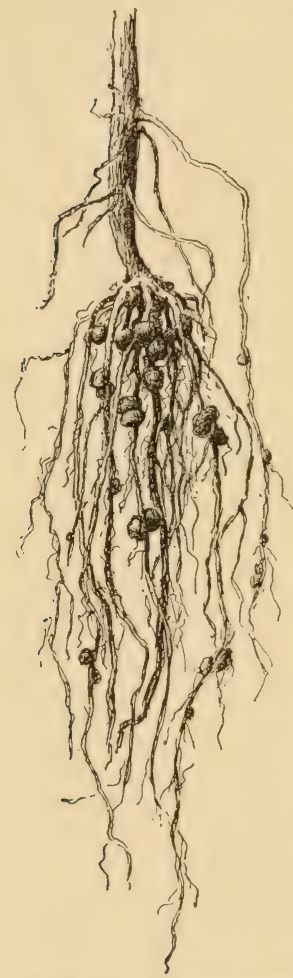

Fig. 15. - TUBERCLes ox RoOTS OF Lagumes can be put out on the land and plowerl under, the soil will catch and hold much plant food that would otherwise be lost.

Bacteria on Legumes. - As far back as the time of the Romans and the Greeks, it was known that clover, beans, and some other crops made the land they grew on better, but it was not known how these plants made the improvement. It was suspected, and even asserted, about half a century ago, that these plants took in nitrogen of the air through the leaves. This was proved to be mtrue. Yet these legumes, or pod plants, were always rich in nitrogen and left the soil rich in it. Some said they sent deep roots into the subsoil and dissolved nitrogenous compounds and other plant food, and brought them up near the surface.

Finally it was proved that plants do get nitrogen from the air, but not through their leaves. They get it through their roots, and by the help, in at remarkable way, of bacteria that live on the roots. If you will dig up a cowpea or a peanut plant, you will finc 
any number of little warts, or tubercles, on the roots. These knots are the homes of bacteria that help the host plant to get nitrogen. Corn, oats, cotton, potatoes, and most crops camnot develop these bacteria on their roots, and hence camnot use the free nitrogen in the air.

A crop of cowpeas, peanuts, or velvet beans grown on a single acre has often been found to contain 200 pounds of nitrogen in its fruit, leares, stems, and roots. A ton of eotton-seed meal does not contain so much nitrogen. Of course, when such a crop is plowed under and rots, the land is greatly emriched. Even when the crop is not plowed under, but saved for hay, the roots, stems, and fallen leaves will enrich the land.

The same kind of bacteria will grow only on closely related kinds of plants. So it is often found that when a legume is planted for the first time in a neighborhood, it is well to sprinkle the land with soil that has already successfully grown this kind of plant or a kind closely related to it. This supplies the new land with germs which inoculate the plant and enable it to produce a better crop.

The effects of restorative crops on the land will be more fully discussed in a chapter on rotation of crops.

Plant Diseases. - These little bacteria and fungi (singular fungus) cause most plant diseases. Cotton rust, grain rust, pear blight, peach curl, tomato blight, and many other diseases are caused by fungi of different kinds. Some of these are very difficult to treat. Many fungous liseases are checked in a great measure by spraying with Borrleaux mixture. Some strains of crops are resistant 
to these diseases. The red oat is much more resistant to rust than other kinds. A strain of sea-island cotton resistant to cotton wilt is said to have been found. In the tropics a small wild tomato grows with perfect freelom from disease, where the finer cultivated kinds usually fail on account of blight. Root rot of cotton is a serious matter in much of Texas and in other sections. The crop dies in patches. Alfalfa, peanuts, peas, different fruit trees, and many weeds are subject to it. The fungus causing it does not live on the roots of sorghum, corn, wheat, oats, etc. Therefore, rotation with these crops is about the only partial remedy known. Melon wilt and cotton wilt are two other fungous diseases that cause great loss in some sections.

Rotation of crops and burning of diseased plants are measures adopted to prevent the spread of all fungous diseases. The treatments for many plant diseases are given in the Appendix.

\section{QUESTIONS}

What do you understand by bacteria? What causes the souring of milk? Is germ life harmful or beneficial to us? What is necessary in order to preserve fruit? Is germ life of much importance in the arts and industries? Is it of any importance in soils and manures? By what means are peas and other erops enabled to enrich the land? How much nitrogen will a big crop of peas or peanuts add to an acre of land? Will all kinds of bacteria grow on all kinds of leguminous crops? What causes grain rust? Are there any grains resistant to rust? What causes potatoes to rot? Why should eut or bruiserl potatoes not be mixed with somnd ones? What about root rot of cotton? What other plants does it attack? What plants are not attacked by this fungus? IIow can one partly get rid of root rot? What other fungous diseases of cotton are mentioned? What disease of melons? 
Experiment. - Dig up peas, peanuts, and other pod-bearing plants, hring them to the schoolhouse, and examine little tubercles on roots. P'rhaps the County Superintendent could acquire a large microscope and let the schools have it by turns. In this case examine germs in milk, water, etc. It will be most interesting. Cut sweet potatoes at home, and inoculate with germs of rotting potatoes and note effects. 


\section{CHAPTER IX}

\section{THE BOTANY OF OUR CROPS}

Plant Families. - Botany, the science which describes plants, divides all plants into great tribes, having certain degrees of relationship or resemblance. Corn, sorghum, sugar cane, vats, wheat, rice, grasses, etc., are put into a large tribe, because they all have leaves somewhat alike, and grow somewhat in the same way. This large tribe is again divided into grains and grasses. Some of the members of this large family are very closely related, as oats, wheat, barley, and rye. Sorghum and Johnson grass are about first eonsins, while milo-maize and kafir eorn are something like double first cousins, or probably as close kin as brothers.

Another large family of plants bears seed in pods. Most of these plants support on their roots bacteria that enable them to feed on nitrogen from the air, as you have already learned. This family includes all the clover's, alfalfa, beans, peas, peanuts, beggar weed, and various other plants. The cowpea is more closely related to the bean than to the garlen or English pea. This family of plants is often called The Legumes.

Cotton and okra belong to another big family, and are rather closely related. Of the fruit trees, peaches and plums are likewise closely akin; also apples and pears. 
Fruit trees closely enough related may be grafted on to each other.

Genus, Species, and Varieties. - While a number of plants somewhat alike are said to belong to a family, or tribe, these tribes are divided into groups still more closely related. Each of these smaller groups is called a genus. The different kinds of clover belong to the genus Trifolium, or three-leaved plants. Each genus is divided into still smaller groups whose members are still more ('losely related to each other. Each of these groups is (ailled a species. Sorghum and Johnson grass are different species of the same genus. Then we have varieties of the same plant. Short-limberl cotton and long-limbed cotton are different varieties. Different varieties of a plant may be said to be as elosely related to each other as hrother's and sisters. (See Appendix for further description of the plant families.)

Length of Life. - Plants that grow on from year to year, like fruit or forest trees, are called perennial plants. So are plants that keep coming up from the same roots, like Johnson grass and Bermuda grass. Plants like cotton and corn, that die, root and branch, each year, and have to come up from seed again, are called anmuals. It is true, cotton is a perennial in the tropics, and lives and grows for many year's, getting as large as plum trees. Certain other plants grow two years and make seed the second year and die. These are biennials. Turnips, beets, and melilotus, or sweet clover, are biemnials.

Storage of Plant Food. - Biennial plants generally store up the first year a supply of rich food in their roots, so 
they grow very rapidly the second year. Perennials store up in their twigs and buds food that causes very rapid growth of young leaves the next spring. So all plants store food in their seed for the use of the young plants until the latter can take root. Irish potatoes may grow a foot high from the food in the seed potato. It has been proved that if large pieces of Irish potatoes are planted, much better yields are secured than when the seed potatoes are eut into small pieces. That is, the young plants, being better fed, get a better start and grow more vigorously if big pieces of seed are planted.

Sugar cane, of course, has a large store of sugar and other food in the stalk planted. The young plant can grow a long time just by feeding on this seed stalk. Sio in the East Indies, where people want time to gather another crop from the land, and yet want the sugar cane early, they start the cane in beds and then transplant the mother stalks bearing the young cane when the other crop has been removed and the land prepared. To lengthen the short growing season in the Gulf States. cane might be sprouted under glass or cloth and transplanted in the same way. Even a mustard seed and a tobacco seed contain some food to start the young plant off.

Plants, if they had intelligence and speech, would tell us they do not store food for us, but for their own offspring. The sap in the sugar maple, sugar cane, and sugar beet, that we take to make sugar, is stored there to support new plants and new growth; so of the starch and other substances in rice, corn, wheat, and barley seerl. 
The rich protein compounds in beans, peanuts, and cotton seed are primarily to support young plants. In one sense we are robbers of the plant kingdom, and must be in order to live.

Roots, Stems, and Leaves. - Plants have roots to hold them upright in the soil and to gather moisture and food from the soil. The stems serve to hold the leaves up to sun and air. The stems, as you have seen, also contain little channels through which plant food and water are carried from the roots upward to the leaves. Then the finished chemical compounds made by the leaves pass back into every part of the plant. The leaves, as we have seen, give off water, and take in carbonic acid gas.

\section{Plants as Chemists. -} By means of the chlorophyll, or green coloring matter, and sunlight, the leaf is able to make starch out of carbon and water. No human chemist can do this. Then the plant readily turns its starch into sugar. Chemists can perform this feat, but they cannot turn sugar back into starch. 'The plant can do this. To the starch or sugar the plant makes, it adds a little sulphur, phosphorus, and nitrogen, which come up in the soil

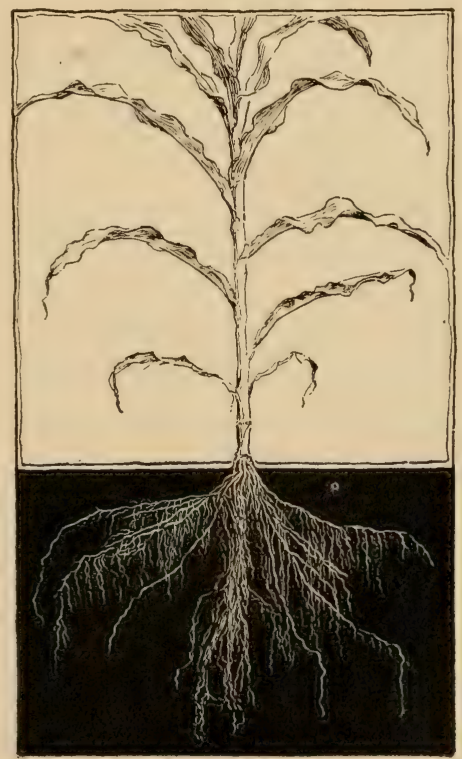

Fig. 16. - Fibrous Ruots of CorN 
water, and a compound called protein is made. Chemists cannot make this, and without it in our food we could not live. Protein will be discussed later under the subject of Feeding Animals.

Kinds of Roots. - Plants are often spoken of as having either fibrous or tap roots. Corn and oats and wheat have fibrous roots. Cotton has a tap root, and of course has many small fibrous roots branching out from this main tap root. The smaller roots of plants are the feeding roots, and even the smallest roots that can be seen with the unaided eye are covered with small hairs that take in moisture and food from the soil.

Length of Roots. - Plant roots grow to a much greater length than one would suppose. Most plants have roots longer than the height of the plant. We often see cotton or corn injured at a distance of forty yards or more from a large green tree. The tree is not shading the crop for any great distance, as some people think. The little roots of the tree are stealing food and moisture from the erop. This injury is greatest in time of drought. It has been estimated that if all the roots of a hill of corn were placed in a straight line, they would reach a mile. Plant roots often go many feet deep, but the majority of the feeding roots of farm and garden erops will nearly always be found in the upper six inches of the soil.

Osmosis of Plants. - If a blardiler containing strong salt water be suspended in a vessel of pure water, the pure water will pass through the bladder rather rapidly, and some of the salt water will pass out into the vessel. 
The most rapid movement will be into the bladder toward the strung solution. The mixing of liquids through a membrame like this is called the principle of osmosis. This is the way in which plant roots take in food and water from the soil. Water containing dissolved salts is inside the plant, and water containing salts is also about the roots in the soil. As the leaves of the plant evaporate water, the liquid inside becomes stronger than that outside. Hence the weaker liquid outside begins to flow through the cell walls of the roots into the plant and the liquid inside passes out less rapidly. As water continues to evaporate from the leaves, the stronger solution will be in the leaves and the weaker one in the roots where the soil water is entering. Hence the weaker solutions move upward from cell to cell. This, at least, partially accounts for the movement of sap in plants.

Beans when soaked swell up until they burst. This is due to the principle of osmosis. The weaker liquid

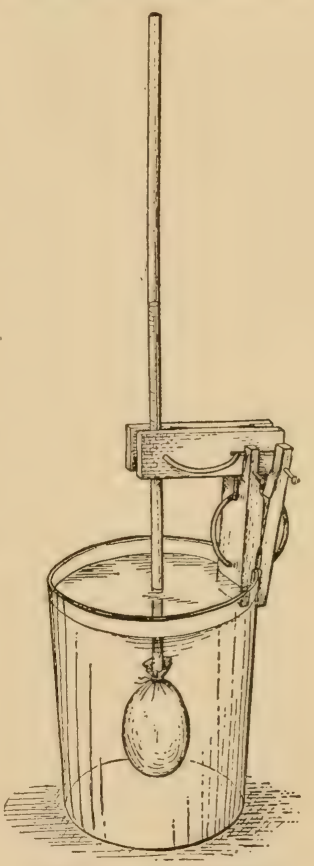

Fig. 17.- SHowINi:

Osmosis flows through the skin of the bean. A shriveled piece of Irish potato will take in water when soaked and become plump. But if soaked in strong salt water, the potato will become still more shriveled, because the juices of the potato flow outward to the strong solution. 
To show the pressure of the flow of sap, cut a small grapevine and fit a rubber tube over it and put a glass

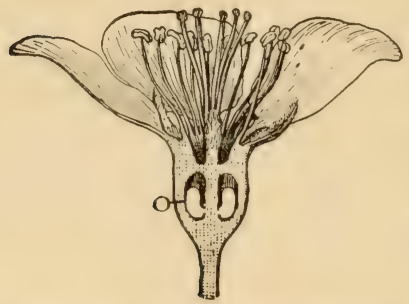

Fig. 18. - Fluwer of the APPLe tube in the other end of the rubber tube. The pressure will raise water in the glass tube many feet high.

Fertilization of Plants. Plants, in order to make seed, have flowers. A perfect flower has stamens producing a little yellow powder called pollen, and a pistil containing the little seed. In order to become fertile and make good seed, some of the pollen must reach the little seed. See Figure 19 for the names of the different parts of the flower. One part of the corn flower is represented by the shoot and silks, the other part by the tassel. As is well known, no grain is made unless the pollen of the tassel falls on the silk of the corn. The ears of corn fill much better in a large field than where there are only a few stalks. In the

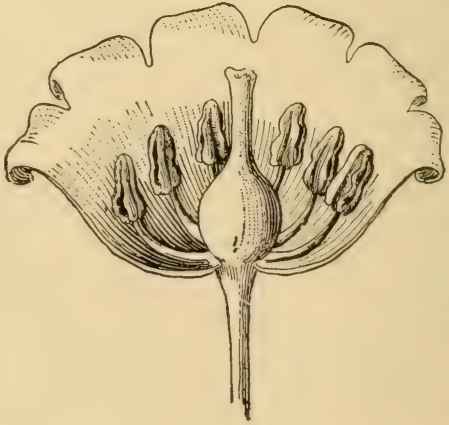

Fig. 19. - Lily of the Valley, SHOWing six Stamens and the Pistil IN THE CENTER

latter case, the pollen is blown off and does not reach the silks. Corn of different varieties will sometimes mix even when the fields are some distance apart; this is 


\section{THE BO'TANY OF OUR CROPS}

due to the fact that the pollen is blown from one field to the other. In order to be sure of effecting the most rapid improvement by selecting seed corn, the shoots of the desirable kind should be covered with paper bags before the silks appear, and then the silks should be dusted artificially with the pollen from the same stalk, or an equally desirable one.

Still other plants have flowers containing pistils on one plant and the flowers containing the stamens on another. Often two varieties of strawberries must be planted close together on this account. Date palms had been growing on the Texas coast for a long time and had borne no fruit. It was supposed they would not bear in this climate. Finally, some one brought flowers from palms growing in Mexico and fertilized those on the Texas trees, and as finc dates as could be desired were produced.

Work of Insects. - Insects aid in carrying pollen and fertilizing flowers. When cucumbers are grown in hothouses in winter, it has been found that fertilization cannot be done so well by hand, and bees have been introduced into the hothouses for the purpose. The bee or other insect gets pollen on its body and carries it to the next Hower visited. The showy colors and the sweet perfume of flowers, it is said, are nature's ways of attracting insect visitor's to the flower's. In the Philippine Islands and Borneo, wherever a few Howers are cultivated, sticks are stuck up with eggshells put on top of them, often giving the appearance of numerous flowers. The people say that the eggshells make the flowers grow better. Whether this is a useless notion, or whether the eggshells may 
help attract the few insects that visit flowers there, the writer has often wondered.

Crossing and Hybridizing. - Plants of different varieties may be crossed by fertilizing the flowers of one variety with the pollen of another. Plants of different species may often be crossed, and the resulting plant is called a hybrid. Crossing and hybridizing sometimes produce stuerior plants, but the chances are that the new plants will be no better than the originals. As a rule the practical farmer and gardener harl best leave crossing and hybriclizing on a large scale to the professional plant breeder's. To every hybrid or eross that is superior to the parent plants, there are hundreds that are inferior.

\section{QUESTIONS}

What is the name of the science that describes plants? IIow are plants classified? Name a near relative of sorghum. Name a distant relative of corn. Name a relative of the cowpea and one of cotton. Can plints not related to each other be grafter together"? Are the plants in a species or in a genus more closely relaterl? What is an annual plant? What is a perennial and what is a liennial plant? What provision is made by all plants in the fall for rapid growth next spring? What is the reason that big pieces of Irish potatoes will yield more when planted than small pieces will? What does the sugar-cane plant feed on when young? In what way do we rob plants? Of what use are roots to plants? Of what use are stems and leaves? Can chemists make sugar out of stareh, and can they make stareh out of sugar? Can plants do these things? What other compound in plants is necessary for animal life? Can human chemists make this compound? What two kinds of roots do plants have? Give examples of plants that have both kinds of roots. How long are the roots of a large tree? Explain the injury a tree will do to a crop in time of 
drought. How deep do plant roots feed? Explain the principle of Osmosis, or the mixing of liquids through a membraue. Explain how the principle of Osmosis enables plants to get food from the soil. What will happen if a shriveled Irish potato is soaked in salt water? What is a flower? What are the principal parts of a flower? Where are the different parts of the Indian corn flower situated? What would happen if all the tassels of corn were cut off? If you wish to be sure that an ear of corn would not mix with other corn, what would you do? Why do people sometines have to plant two kinds of strawb-ries near each other? Why would the date palm not bear fruit in Texas, and what was done to make it fruitful? Of what use are insects to plants? Of what use are the pretty colors of flowers? What do we mean by "crossing" plants?

Experiment. - Plant on the farm at home one row of corn from nubbins and a row from fine ears, and see if there is a great difference in yield. Report next session for the benefit of the school.

Plant at the proper season at home a few single eves of Irish potatoes, cutting each eye off with a very small, thin piece of potato. Then plant pieces as big as walmuts, with all eyes cut out but one on each piece. Note how much better plants the latter will make. Make report next session.

Watch a few stalks of corn growing in garden, and if you wish take out all the tassels when they first appear. Note that few grains or none at all will be.made. 


\section{CHAPTER $\mathrm{X}$}

\section{GRAFTING AND BUDDING}

MANY plants do not produce offspring like themselves when their seed are planted. This is true of peaches, apples, plums, pecans, and other fruit-bearing trees. You may plant a seed from ever so fine a peach, and you are nearly certain to get a tree bearing inferior fruit. If you plant the finest paper-shell pecan, the chances are you will get a small, hard nut. But if a bud or graft be taken from a good kind of tree and marle to live and grow on a stock of any kind, it will always bear fruit like the tree from which it was taken.

Budding. - Figure 20 shows the common method of budding. Budding must be done in summer when the bark slips readily. Peaches, plums, and cherries are generally budded rather than grafted. Young seedling trees are grown in large numbers, and buds of desirable kinds put under the bark of the seedling plant near the ground. In the Sonthern States peaches are often burlded in June and September. When the June bud is found to live, the top of the stock is broken above the bud and allowed to remain attached until the but begins to grow vigorousiy; the broken top is then entirely cut off, and the new bud makes the tree. The tops of the stocks budded in September are not cut 
avay until the following spring. The Japanese persimmon may be budded into seedlings of the common persimmon grown in the same way as peach seedlings.

Figure 21 shows the ring method of budding pecans and oranges commonly practiced in the South. Buds of the finest kinds of pecans may be inserted in pecan seedlings or hickories. If the hickory or pecan trees on which the grafting is to be done are old, the limbs and tops
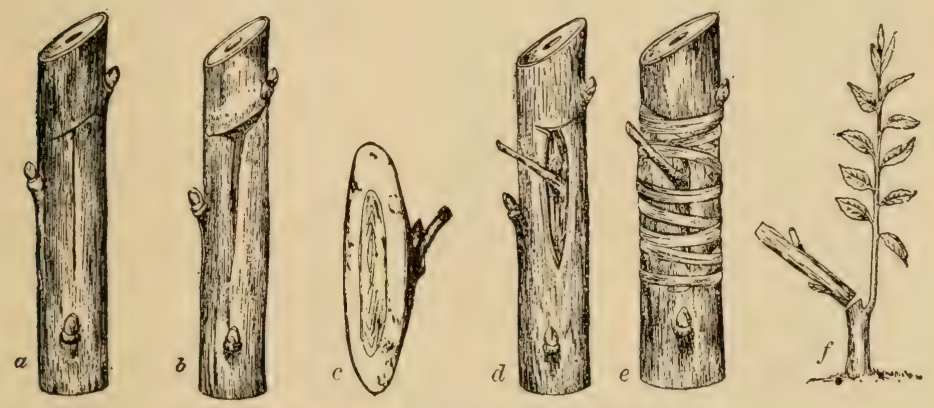

Fig. 20. - Steps in Budding
a. Cuts in Stock
d. Bud Inserted
b. Bark Slipped Away
e. Bark Wrapped
c. Bud
$f$. Bud making New Tree

should be cut off in the winter so that a new growth will be put forth. Several buds are inserted in the new wood the following summer, and then fine kinds of pecans will be produced in two or three years (see Fig. 2t). Satsuma orange buds are grafted into a hardy, worthless orange, called the trifoliata, grown from seed. As the sap ceases to flow vigorously in this trifoliata stock in the fall, the trees become so nearly dormant that they are not much affected by cold. Hence we have a hardy 
and valuable orange for South Texas, Lonisiana, and other Southern states, where the orange industry is one

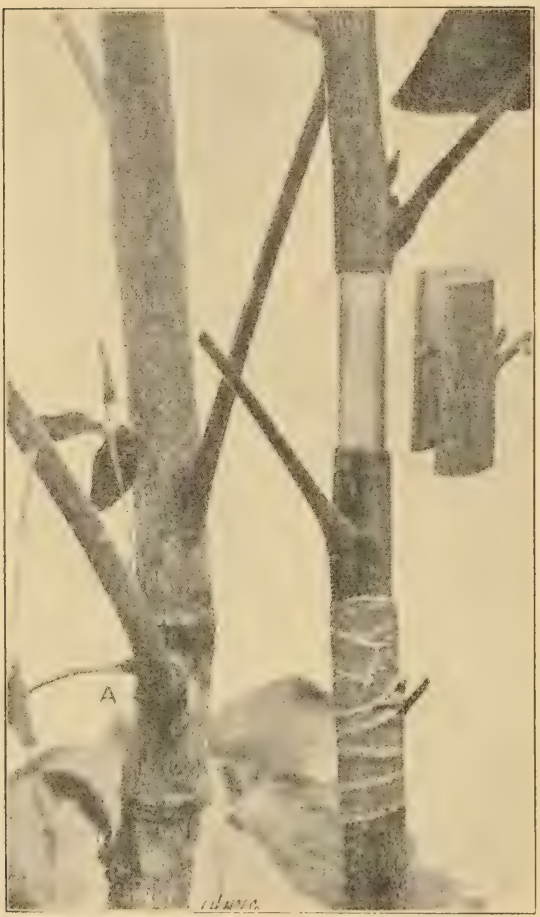

Fig. 21. - Ring BudDing For Oranges and PeCAns of great promise and is already assuming commercial proportions.

Grafting. - Apples and pears are more often grafted than budded. Seeds are planted and many young plants produced. 'These form the stock on which cuttings, or scions of good varieties, are grafted. Figure 22 shows different methods of grafting. Grafting is generally done in winter and very early spring. The main caution to be observed is to see that the inner bark of the stock and scion exactly join for at least a part of the way around, so that the saj) can flow back and forth.

Different species of plants may be grafted or budderl on each other, as apples, pears, and quinces. This is also true of cherries, peaches, and plums, and with pecans and 
hickories. Better results are often secured when the stock and the scion are of the same species.
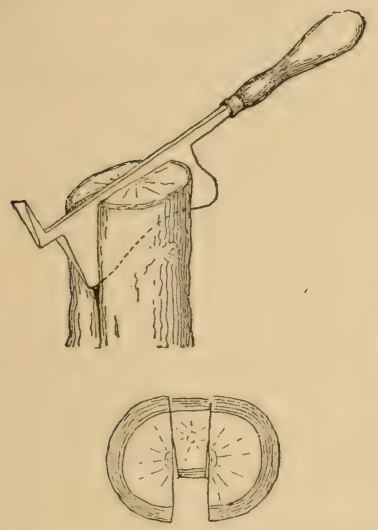

Fiti. 2.2. - (irafintixi

$a$. Scion ; $b$. Stock

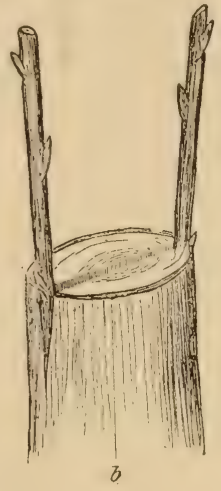

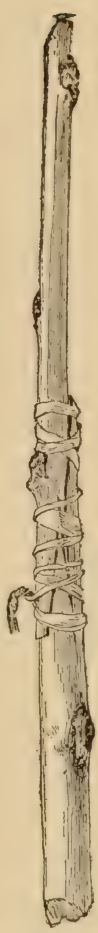

Whip Graft

\section{In almost every neighborhood} there are men who are skilled in budding and grafting. It is suggested that each pupil seek an opportunity to witness the art of budding and grafting, and by a little practice, learn to do it.

Cuttings and Layering. - It is often not

FIG. 23. - THE

PROP ER

DEPTH TO PLANT FIG Cutting necessary to bud or graft in order to propagate and multiply plants. Nany plant cuttings simply stuck down in favorable soil 
will live and grow. Figs are fairly easily multiplied in this way by planting cuttings in winter or early spring.

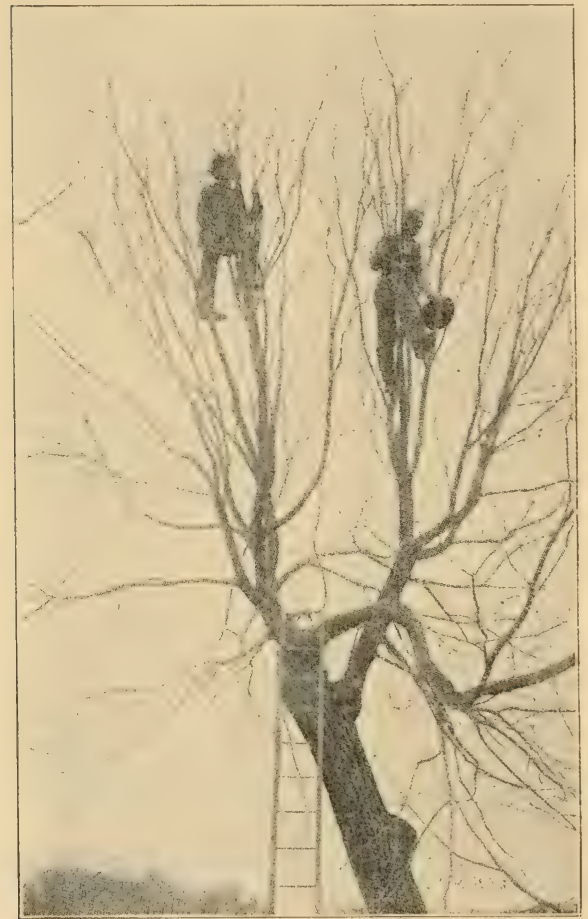

Fig. 24.-Old Pecan Tree growing PaperSHELL Buds
The limbs of other plants may be brought down to the ground and covered, and when they take root, they may be set out as any other plant. This is called layering. Grapes are often propagated in this way.

In the tropics most plants grow from cuttings set in the early part of the wet season. There one may often see a ball of mud tied to a limb which has been cut half in two, or had the bark cut. This is done to encourage rooting at that point. This methorl is about the same as ordinary layering.

Runners. - Many plants are multiplied by root stocks or rumers. The blackberries and rasplerries put up numerous plants from the roots. They are propagated 
by planting pieces of roots. Strawberries send out runner's that root and make new plants. Bermuda grass, in this climate, is propagated from the trailing stems that root at each joint. It may also be produced from seed got from the tropics. Johnson grass, one of our most chraded pests, grows from seerl and from large, fleshy, jointed underground stems, usually called roots.

\section{QUESTIONS}

Sinpose you plant the seed of tine peaches, will they always produce trees having fine fruit? What is necessary, then, in order to reproduce fine peach trees? What other fruits will not come true from siped? What two methods do we have of multiplying such fruits? Describe budding. Describe different methods of grafting. How are oranges propagated in the Crulf States? Do we graft or bud apples and pears? At what time of year is lutdding done? What time of year is grafting done? How are figs propagated? How are grapes propagated? IIow do we propagate strawberries, blackberries. and raspberries?

Experiment. - Practice grafting and hudding and see what success youl have. 


\section{CHAPTER XI}

\section{SEED SELECTION}

PEOPLE appear to believe in selecting the best seed for planting and the best animals for breeding. Yet, as a rule, but a half-hearted effort is made, especially in regard to seed selection. It is true, a great deal of money has been spent for seed which are supposed to represent years of careful selection, and which are claimed to have a producing power two or three times as great as the seed usually planted. These purchases have generally been disappointing; the seed in many cases have proved to be not so good as some of those planted for years in the purchasers' neighborhood.

Do Seed run Out? - It is not true, certainly with most crops, that seed "rum out," and that new seed from a distance must be brought in. In fact, it has been generally found that seed of a certain variety of crop' grown in any locality will be better for that locality than those brought in from a distance. Seed grown in a locality for a number of years go through a process of adaptation and natural selection, better suiting the crop' to its conditions. Of course the farmer can hasten this adaptation by intelligent artificial selection of planting seed. In this way corn has been developed to grow farther north, wheat to suit certain sections and give 
better yields; cotton is being developeed to make far (rops ahead of the boll weevil, ete. ()ther (rops have been adapted to resist disease. In a measure. also, varieties of erops have been procluced to suit different types of soil, to vary in their fertilizer recuirements, resistance to excessive wet or dry weather, etc.

Plants resemble Parents. - In a general sense, a plant is like its parents. It is not true, however, that seed from at nearly perfect ear of corn will, of necessity, produce only stalks having perfect ear's. A fine ear of corn may have been fertilized (pollenized) by one bearing a little nubbin. The nubbin may have been pollenized by the stalk having the fine ear. In that case the nubbin would make as good seed as the fine ear, if the grains are as somnd

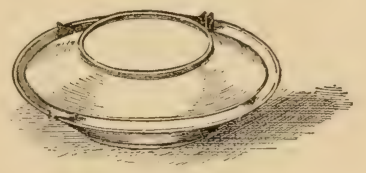
and individually as large. Even if the fine ear is crossed with another stalk having a fine car, and the nubbin with a stalk having a nubbin, it is not at all likely that the seed will be so widely different in productive power when planted as the parent plants were. Lach grain las in it not only the strain of its immerliate parents, but of a hundred generations of parents. ()ne or two generations of nubbins, or even almost barren stalks as ancestors of one parent, caused by poor soil, poor ('ulture, or drought, will not be likely seriously to reduce the yield when planted, if goor conditions are again provided. 
The Farmer his Own Seedsman. - As far as yossible every farmer should select his seed in his own neighborhood or on his own farm. He should select seed with a view of obtaining a size and type of plant that suits the soil and seasons of his locality. It is highly probable that all the desirable qualities cannot be combined in any one type of cotton, for eximple. Wre should like earliness, hardiness, prolificness, high per cent of lint, large bolls, and long staple. It is probable that some of these qualities are antagonistic to each other, and consequently all of them can never be fully attained in one variety. IBut large bolls, earliness, and at least fair prolifieness, can he obtained in short staple cotton. This has been proverl many times.

Sound, Heavy Seed. - The farmer should see to it that only sound, heavy seed are saved. The Department of $\Lambda$ grieulture at Washington has devised a little machine to separate light cotton seed from heavy, plump sexd. The latter, in a planting test, gave a much better yich than unseparated seed. Good stands of all cropss are necessary in order to make good yields. Seed corn in the corn-growing states is often unsound, and the poor stand resulting "uts off the yield several bushels per acre. Of conrse soorl, sound, heavy seed of all kinds should be insisted on when buying. As all seerl lose their vitality with ane, new seed should be demanded. Seed bought should be subjecterl to a germination test. That is, one hundred average seed should be kept under a moist cloth, or in moist sand, at a temperature suitahle to germination, to see how many are good. 
Weed Seeds. - In buying alfalfa, clover, wheat, oats, and many other seeds, one should be on his guard against introducing the seed of noxious weeds. In examining many samples of alfalfa seerl brought into Texas, the Experiment Station has found large percentages of dorlder, Russian thistle, dock, and other exceedingly bad
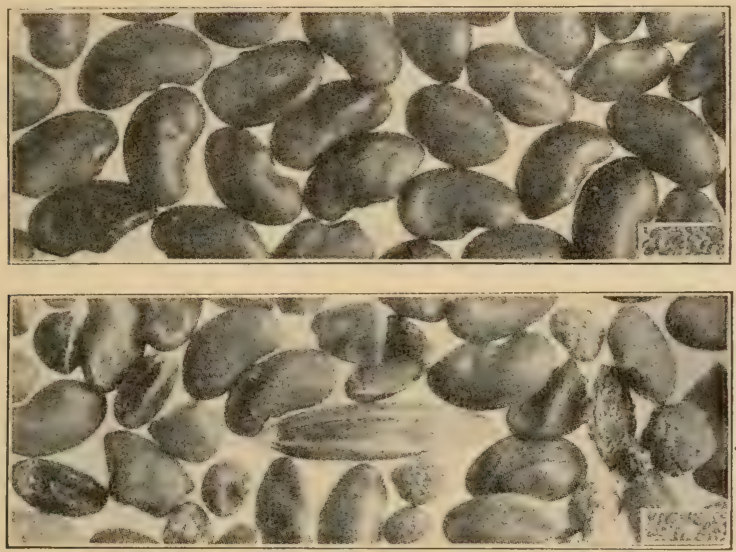

Fig. 26. - Pure and Impure Alfalfa Seed, Magnified

weeds. Oats and wheat are very likely to carry Johnsongrass seed, when grown in sections where that grass exists. It would be advisable to have a microscopic: examination made of all seed that are likely to have mixed with them the seerls of harmful weeds. No doult the experiment stations and agricultural colleges of all the states will do this work free of charge.

Watching for Sports. - The farmer, by careful watehing for just the type of plant wanted, and selecting, keeping pure. and planting, an acemplish much more than by 
artiticially stimulating big yields and depending on these seerl to make bigg yields. I new type of plant is called a sport. Sports do not always breed true, but they often do, and thus produce new varieties. An extraordinary crop secured by high fertilizing, good seasons, etc., will not be likely to afford better seed than a crop which has made a poor yield on account of unfavorable conditions. The large yields of many of the high-priced seed which are sold are due rather to high fertilizing than to special merit in the seed.

Dr. de Vries and I)r. Nillson, quite noted European plant breeder's, pronomeed the plan of the German plant breeders a failure. The German plan is to select a large amount of seed from the whole of a good crop and plant these together. Dr. (le Vries and I)r. Nillson wateh for a single plant differing from the others and of a desired kind, called a sport, then isolate it and multiply from it. In this way they daim to have accomplished certain and excellent results.

All the evidence points to the fact that if there is any variety which is best for a given locality, it will not be the best for all localities growing this crop. With a long season of growth and plenty of rain, a late-maturing kind of corn will outyield an early kind. But for a northern latitude, or the dry western climate, we should hardly recommend the large-stalked, late kinds of corn. It is also evident that the same lind of cotton does not do equally well over any large extent of country.

Limits to Improvement. - It seems reasonable that (rops that have been highly improved alrealy camnot be 
improved so rapilly in future as in the past. That is, a limit ean be reached somewhere beyond which improvement cammot go on. It is said the sugar beet has had its sugar content doublerl since Napoleon began its improvement as a means of raising revenue for his wars. Whether this is true, or part of the improvement actually came from better handling and later ripening of the beets and better methods in the factories, it is immaterial. It is true, however, that the sugar content of the beets grown in Germany, the greatest sugar-making country on earth, has not increased on an average so much as one per cent on the weight of the beets in nearly forty years.

Java, next to Hawaii the most intensive cane-sugal country in the world, was forced to give up its sweetest (ane and grow a vigorous, hardy kind, able to resist certain cane diseases. The same country once grew an immense quantity of as fine coffer as was ever known. Disease came and entirely destroyed the industry, which is now being built up again, with an inferior but hardy kind of tree, able to resist the disease.

Less hardiness and less resistance to disease seem generally to follow improvement in other directions. Whether this evident tendency can be guarled against and disease resistance combined with improvement in yield and quality of product, are questions as yet unknown. Such a combination has not been attained in improverl live stock, and certainly has not in most cases with improved plants. Hopkins, of Illinois, has bred corn to contain some 45 per rent more protein than arerage rorn. In roing so. he 
appears to have reduced the size of car's, and presumably the yield of corn, about 25 per cent.

Potatoes and Cane. - Planting small sweet potatoes and Irish potatoes is a general practice in some sections, and has been for generations, but potatoes show no markerl tendency to become smaller. It is true that planting small Irish potatoes, where they are cut to two eyes, will result in smaller yields than larger potatoes cut to two eyes. You have seen why this is so. When the same sized pieces are cut from small potatoes as are cut from large potatoes, there will be more eyes in the pieces cut from the smaller potatoes, and with some varieties several of these eyes come up, resulting in too many plants, and consequently a larger proportion of small potatoes.

Above the Louisiana sugar belt proper the practice of sirup makers has been for years to save for planting the small, worthless stalks of cane. In the tropics the practice has been for ages to plant the immature, worthless tops. In neither case has any deterioration in the cane occurred. In the tropics much experimental work has been done to find the effects of planting propl stalks and tops, but no change one way or the other has been found.

In the case of sweet potatoes, Irish potatoes, and cane, we plant parts of the old plants just as in budding and grafting. In each of them real seed may be grown, and are grown and planted. When sugar cane grows a year or more in the tropic's, it makes a head of fine feathery seed. These are planterl and at little, weak stalk of cane 
is produced. This stalk is planted and cane is produced in the usual way, but there is never any telling what kind of cane it will be. It is never likely to resemble the parent, and is entirely likely to be different from any other variety of cane ever producerl. You are more likely to get

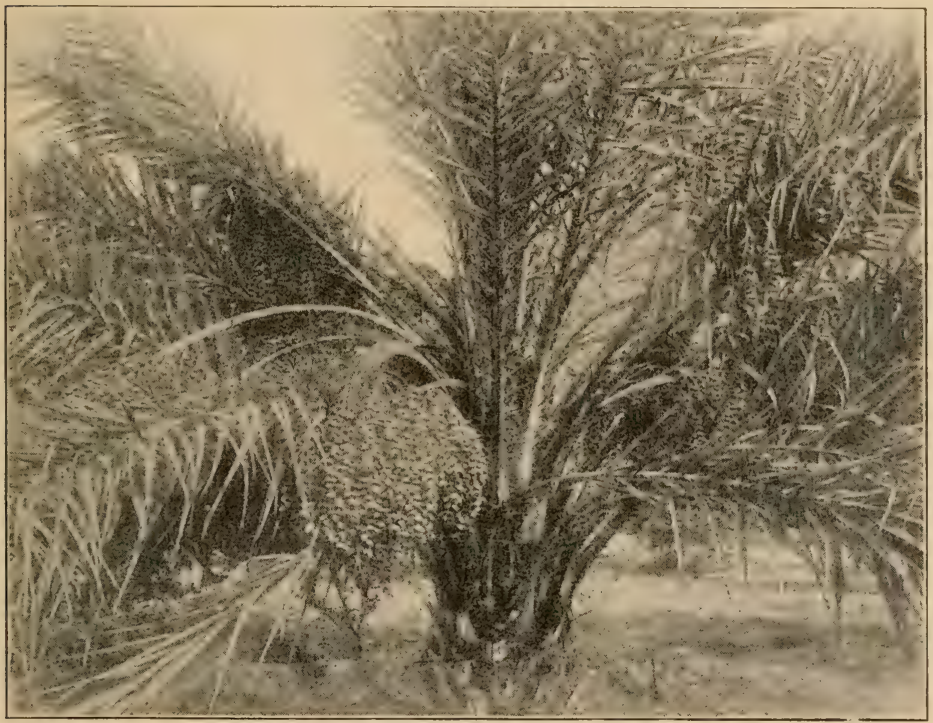

Fig. 27. - New Mexico Date Palm

from the seed of red (ane either white, green, striped, or even black cane, than red cane. Only one in thousands of the kinds produced in this way has been found to have better qualities than well-known kinds. Irish potatoes and sweet potatoes are said to show these same variations when grown from real seed.

Other Seed-producing Plants. - IVith plants that ross 
pollenize, variation is much more likely to occur. Luther Burbank plants a vast number of seeds of each kind, and watches for sports. By growing this sport and fixing the type by preventing aross fertilizing, he obtains the new variety.

Rapidity of Improvement. - Plants are not so rapidly and certainly improverl ly usual methods of selection and hreeding as some people believe. Of the one hundred or more so-called varicties of cotton testerl at several fonthern experiment stations, no one kind has often made the best return two rear's in succession at the same station. No one kind that yielded best for early planting laas often yielded bast for late planting. No one kind has often male best returns the same year at any two stations. Frequently the variety that yields most on one kind of land yields least on another kind. If we take averages, the kinds known to be old have yielded marly as well as those which are claimed to have heen improved in recent years.

\section{QLESTIONS}

What are comparative merits of home grown seed and seed brought from a distance? What about seed "rumning out"? What have "xperiment stations found ont ahout the best variety of cotton? IIow ahout seed from a crop that was poor on account of drought? Can seed be improved by merely fertilizing the crops? Tell about the experience in planting sugar cane and potatoes. What is a "sport"? How are new varieties produced? ('an all desirable qualities be combined in one variety of plint? What sort of com should be seleeted for a dry country? IIow are seed tested? What undesirable plants are likely to be introduced in seed? To what extent do you think we can go on improving our crops? 
Experiment. - Lse a magnifying glass and examine seed of altalia, turnip, and other small seed for weed seed, rotten seed, ete. Makw germination tests at proper season with different seed. You may have heard the old saying that wheat turns to cheat. Suppose you get some cheat seed and some pure wheat seed and plant each separately in boxes. See if each does not make its own kind. You can do these things at school. 


\section{CHAPTER XII}

\section{IMPROVING THE LAND}

THE rapidity with which lands wash and wear has already been mentioned. The humus of Southern soils has been found to decrease much faster than in northern lands. The same open winters and heavy rainfall that cause the waste of humus and soluble plant food also cause the soil of much of the rolling Southern lands to wash off into the valley's and creeks, leaving red gullies and poor subsoil.

Poor Land Unprofitable. - The question of improving the soil is the great question of the farm. If one-fourth of a bale of cotton to the acre pays all expenses of its production, including land rent, labor of man and team, seed, gathering, ginning, marketing, etc., then a half bale to the acre will pay over twelve dollars an acre net profit when lint sells at ten cents a pound and seed at $\$ 20$ a ton. While a quarter of a bale makes no net profit, a half bale to the acre makes a net profit as large as \$120, drawing: ten per cent interest. If fifteen bushels of corn to the acre pays all expenses, then thirty bushels at fifty cents a hushel will pay a net profit of about \$7.50. Poor, worn land producing small crops is very poor property; but good land producing large (rops pays hetter than almost any other kind of investment.

Land Easy to Improve. - The building up of the soil is the surest and quickest way to make large and profitable 
crops. It is not difficult or expensive to improve land which produces a quarter bale so that it will make a half bale or even a bale of cotton to the acre. Nuch of the thin land of the South which now yields only fifteen bushels of corn or less to the acre could be easily made to yield thirty bushels or more. It is a general fact that the thin. poor lands are the easiest lands to improve.

Amount of Plant Food. - If even the poorest land is analyzed and calculations marle of the amount of phosphoric acid, nitrogen, and potash contained in a depth of three or four feet, enough plant food is found to support sereral hundred, or pertiaps a thousand, big crops. But such land ceases to produce well because crops and the leaching and washing of the rains have taken away most of the soluble, or available, plant food. Perhaps almost all the humus has been exhansted and the land is no longer dark in color, porous, and fresh, as it was when it was new. With most of the humus gone, germ life laas little to feed upon, and germs no doubt play an important part in dissolving plant food and making it fit for plant use.

Nature enriches Land. - If this poor land is left uncultivated, grass and weeds and briers and bushes soon take possession of it. These hardy plants thread the soil and subsoil with their roots, which can extract food out of the poorest land. If protected from fire these plants make a shade and a soft covering for the land. When they die they decay and form humus. The roots decay and leave channels for air and water to pass through the soil. The shade and humus encourage germ life, which thrives and 
multiplies. Rotting vegetable matter also feeds and shelters innumerable earthworms and other low forms of animal life that burrow and eat and grind and pulverize the soil. By a few year's of such treatment, nature makes this land just as fresh and productive as it ever was.

With a crop of peas, velvet beans, or peanuts, or a coat of barnyard manure now and then, land should retain its freshness and productiveness. By such management it will remain fresh and open and porous; the air can enter: it will hold moisture hetter; germ life will thrive, and all these things help to dissolve plant food in the soil for the use of crops.

Physical and Chemical Improvement. - Improvement in land may be effected by adding chemical plant food in the form of concentrated fertilizer, or by making some physical change in the soil. Plowing or draining would be al physical improvement. Adding sand to a tight, heary soil, if it could be done protitably, would often help it, and yet the sand may have no plant food. Coarse manure contains plant food, but one of its chief uses is to open II) the land or otherwise put it in better physical condition. It adds vegetable matter, or humus, to the soil, makes it drain better, and lets the air enter. It also makes a coarse, sandy soil less jorous, and causes it to hold water better. A good supply of humus is the cornerstone of soil improvement, particularly for the worn uplands of the humid part of the South.

Terracing. - To prevent rolling lands from washing, a very suceessful plan followed in the South Central and Southeastern States is to lay off with a cheap leveling in- 
strument lines around the hillside on a dead level. A sharp bed is thrown up on these lines with a turn plow

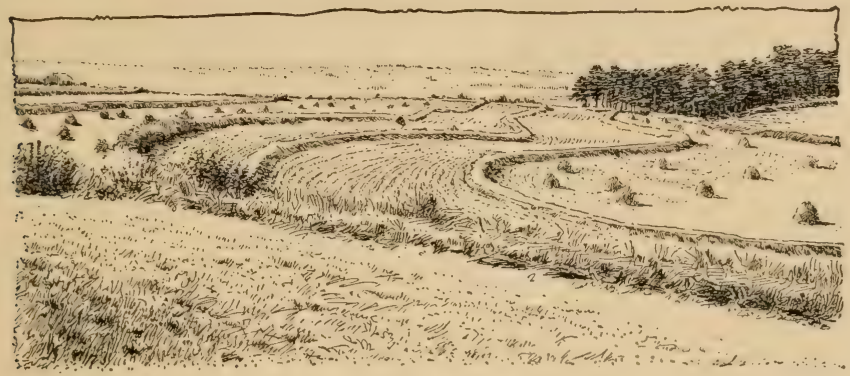

Fig. 28. - TERRACED LAND

and weeds and grass are allowed to grow on them. These lines are generally run so that one will be three perpendicular feet higher than the one next to it down the hill. Of course, the lines will be closer together on steep land than on gently rolling land, and they will be closer together at some points than at other points. Rows are gen. erally laid off parallel to each of two terraces, beginning, say, above one and laying off until

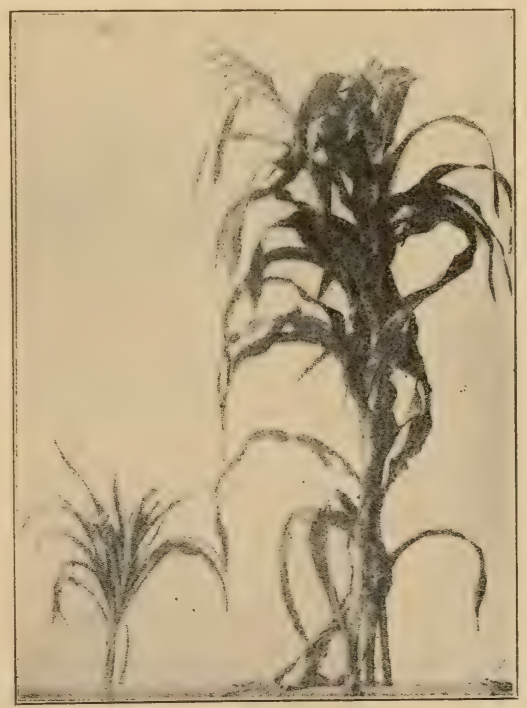

FIg. 29. - CORN GROWN ON WASHED AND ON Terraced LAND 
halfway to the next terrace up the hill at the point where the two terraces are nearest together. Then begin below this next terrace and make rows till this halfway point is reached. Last of all the short rows are filled in. This scheme enables each row as nearly as possible

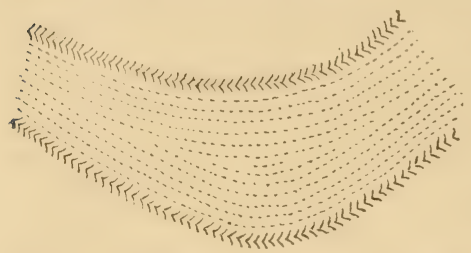

Fig. 30. - Terraced lind and Rows to take care of its own water, while whatever water breaks over the rows soon comes to a terrace line covered with weeds and grass. Here the speed of the water is checked, and whatever sediment it carried is deposited. In a few years the old terrace lines are richer than the other land. These are plowed up and the terraces made along new level lines. Figures 28 and 30 will make clear the description of this plan for preventing washing.

Drainage. - There is a great deal of land in all humid sections that is mproductive because of poor drainage.

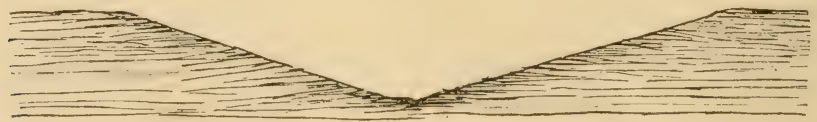

Fig. 31. - Best Shape For AN Open Ditch

We have seen that too much water makes the land cold, shuts out air, prevents the growth of microscopic life, etc. Straightening channels of small creeks, clearing out obstructions, and making a few simple, open ditches will often make much excellent ereek bottom land very productive. Any open ditch or chamnel for water to flow in should 
be made widely $V$-shaped (Fig. 31). Such a channel will always clean itself out much better than a wide-bottomed ditch, and will not be liable to cave and fill up. Often by merely starting such a channel with a plow and replowing after heavy rains, one can make excellent drainage channels at trifling expense.

Draining Marsh and Creek Lands. - Near the seacoast there are immense bodies of marsh land too flat to be drained in such a way. This land needs to be surrounded with low levees with channels cut through them, and to have the water pumped out over the levees. A trifling amount of pumping will permanently drain such lands and make them highly valuable. The drainage canals might be made the very best and cheapest means of transportation. Holland has hundreds of square miles reclaimed even from the sea at a cost of perhaps over one hundred dollars an acre. Even rivers are pumped out over the grear levees, or dikes. This land is below sea level and is cut here and there with drainage canals. The people are said to go to market in boats in summer and on skates in winter.

There are also large bodies of fine creek bottom land that could be drained by dredging out straight channels for some miles. As this is usually too large an undertaking for one man, the land to be reclaimed should be organized into a drainage district and taxed or bonded to get money to make the improvement.

Tile Draining. - A great deal of land in the Northern and Central States is drained with tile, or burned clay pipes. These pipes are laid end to end in ditches dug 
at suitable distances, and covered over. 'This makes an excellent and permanent system of drainage. Tile drains do not draw water from the land any better than open

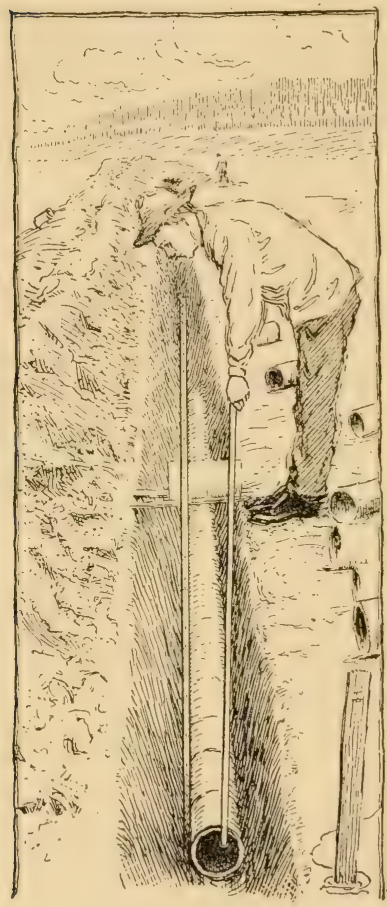

Fig. 32, - Tile Draining ditches of equal depth; but they are never in the way of teams or machinery, they eause no loss of land, and they never fill up when well laid. When tiles are once laid, the expense is over, but open ditches have to be worked on every year.

In the Gulf States there has been almost no tile drainage, because land has been cheap and tiling has been costly. Perhaps the cost of tiling an acre would buy two acres that do not need tile. Moreover, the seasons are long, and we can generally wait for the excess of water to dry off, and yet have time to make a crop. Figure 32 will show the method of draining with tiling.

As our lands increase in value and we come to want to use our whole season in maturing two or more crops, tiling will likely come into favor.

In some places, brush, poles, rocks, etc., have been put into ditches and covered over so as to make cheap underdrains. 


\section{QUESTIONS}

Why do Southern lands wear out more rapidly than Northern lands? Why do Eastern lands exhaust faster than Western lands? Why is good land of such great importance to the farmer? What lands are generally most easily improved? Suppose exhausted land grows up in weeds, grass, and briers, will it become productive again? Should land thus growing up be burned off, or should the growth be allowed to rot? What can we do to improve poor land faster than turuing it out? Besides growing crops on land to improve it, what can we add to it? Give an example of physical improvement and chemical improvement of land. Describe the plan used in the Southerm States to prevent hilly or rolling land from washing into gullies. What can be done to make creek bottoms productive? What shape should an open ditch have to be most serviceable? What can be done to make large areas of flat marsh land productive? What country has reclaimed from the sea a great amount of land? How do people go to market in that country? Describe tile drainage. Why have the Southern people not used much tiling?

Observation. - Observe how much more productive old fencerows and old building sites are than land regularly cultivated. Observe how much better crops are grown this year on land that grew peas last year. Note how much better the crop often is near a ditch where drainage is good than farther away where the land is not so well drained. 


\section{CHAPTER XIII}

\section{ROTATION OF CROPS}

English Rotation. - In England, clover, turnips, beans, and wheat follow each other in regular order, and constitute a five-year rotation. The lands of Great Britain were once so poor that only about three bushels of wheat were raised for each bushel planted. While invading France, the people learned the value of such crops as clover, turnips, and beans. By rotation of crops, bone fertilizers, and stock feeding, they have built up the land till it makes over twice as much wheat to the acre as the land in the United States.

A Southern Rotation. - If an East Texas farmer plants on a field cotton one year, corn and peas the next year, and oats followed by peas the third year, he not only has an excellent three-year rotation, but grows five crops in the three years - two of them restorative crops. Where cotton can be matured and gathered early, it might be a good plan to have the oats follow the cotton. Corn and peas leave the land very dry, and oats come up much better if sown on land that has been well worked in cotton. It might be well to sow oats after one of the pickings and cover them with a cultivator run between the rows.

Different crops do not require different elements of plant food. They all require the same elements, but they 
use them in different proportions. 'Therefore, one kind of crop may temporarily exhaust the soil of one element, and cease to grow well, while another crop can still do well. But the greatest benefit of this, or any other rotation, arises from the restorative crops grown, and the

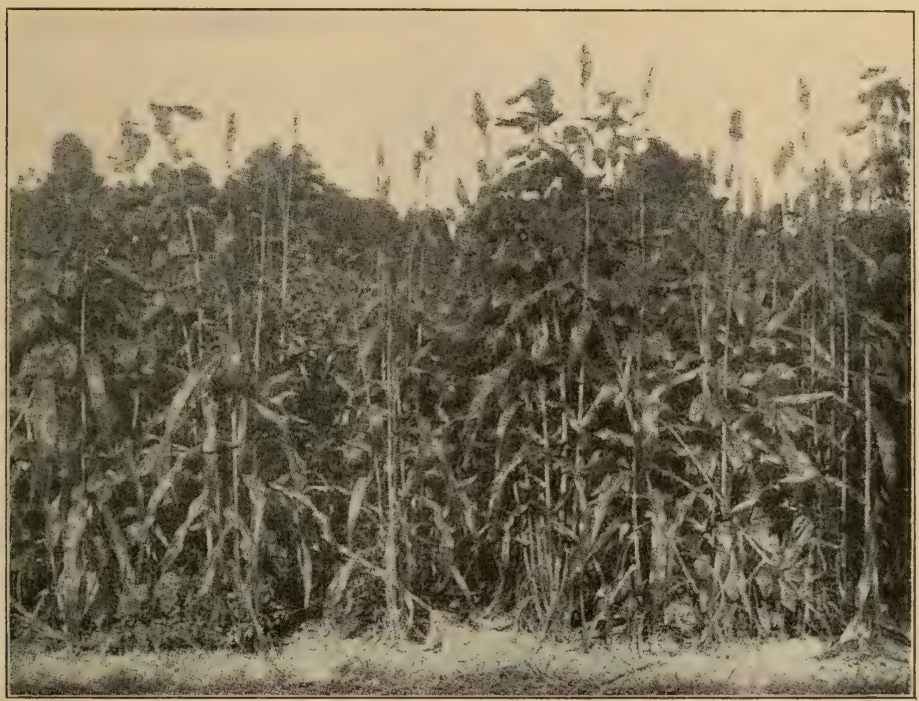

Fig. 33. - Cowpeas And Sweet Sorghum

great amounts of nitrogen the bacteria enable them to get from the air.

Cotton Every Year. - The constant planting of land to cotton rapidly exhausts the humus of the soil, because if cotton is cultivated close and clean, there is little in the way of grass, weeds, and trash left to rot on the land. For the same reason cotton land washes badly. A corn and pea crop, followed by an oat and pea crop, will build up the 
land rapidly; for these crops leave stalks, stubble, and vines, which, when plowed under, rot and make humus, and supply plant food.

A good system of rotation also affords an opportunity to use commercial fertilizers most profitably, if the land is of a kind that responds to fertilizing.

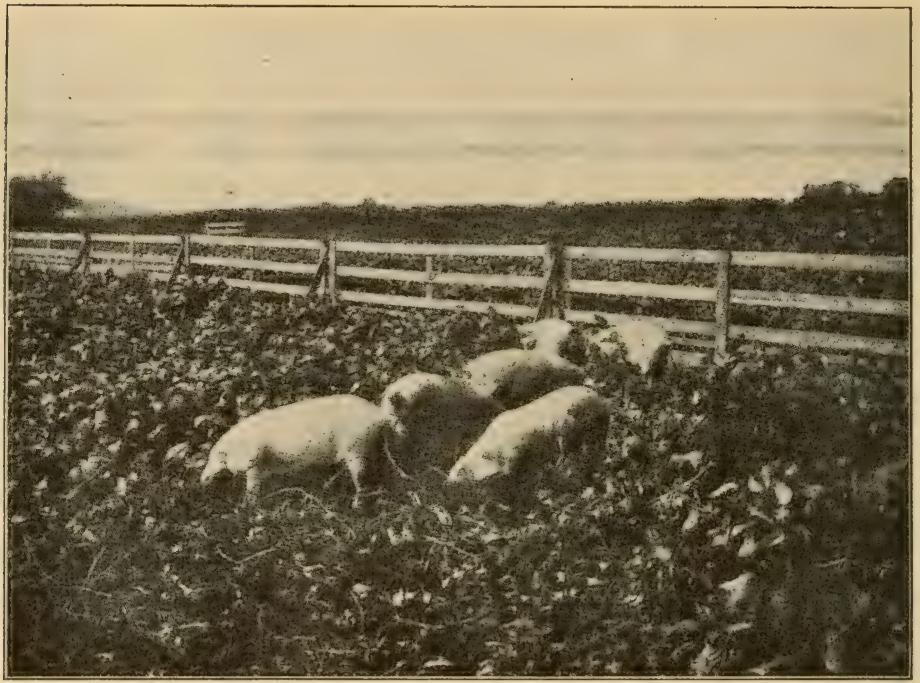

Fig. :3t. -- Hogs arazing Cowphas

Fertilizing Restorative Crops.-Commercial fertilizers have their best effects where there is plenty of humus. A pea crop does not need nitrogen in its fertilizer, as it gets nitrogen from the air. It will seldom need potash. So it can be fertilized cheaply with acid phosphate, which supplies only phosphoric acid. The yield of pea vines will often be doubled by this cheap fertilizing, and conse- 
quently the nitrogen the peas get from the air will be doubled, and the good effects on the land will be greatly increased. Since land once well enriched with pea vines needs only acid phosphate for corn and cotton, all the fertilizing can be cheaply done.

The teacher and the pupil are referred to bulletins of the Louisiana, Mississippi, and Georgia Experiment Stations, which give the results of many years of work with this three-year rotation in connection with commercial fertilizers. In each state very poor land was soon built up so that it produced a bale of cotton to the acre, and other crops in the same proportion.

Dividing the Farm. - To follow such a rotation, a farm should be divided into three parts, having one third in each crop each year. This plan would better distribute the labor of men and teams over the season. It would afford so much corn, peavine hay, oats, etc., to feed on, that more stock could be kept and more manure saved, - both of which would be helpful in further building up the land.

It would make no particular difference if cotton now and then should be grown two years in succession on a field, or if oats should be left out once in a while. Other crops might be substituted for some of those mentioned. One need not follow absolutely any particular plan of rotation. Some lands are not equally well suited to all these crops, but grow one particularly well. Such lands may well be used for one crop and fertilized, if need be, to keep up their fertility. Then certain land for orchards, gardens, and for other special purposes could be set aside, and the rest of the land could be used for crops in rotation. 
Other Rotations. - Rotations may be changed to suit the crops, and to some extent the markets. In the lime lands, alfalfa should be a particularly valuable crop. Once planted, it would be profitable as long as a good stand holds out, maybe five or six years. The land could be used for alfalfa so long, and then planted in cotton and corn five or six years. In some sections wheat may be substituted for oats in the rotation.

Rice land would be greatly benefited if, in off years, when the planter is waiting to get ric of red rice, the land could be drained and grown in cowpeas or other restorative crops. The sugar planter generally rotates his cane land with corn and peas. In West Texas, small grain should be followed with cowpeas the same season, provided cotton, corn, kafir, milo, or sorghum is to grow on the land next season. The land should catch enough rain and snow, especially if plowed and harrower in early winter, to bring up the spring crops. But if fall-sown grain is to follow small grain, then the land should be plowed and kept disked to make it moist enough to bring up seed in fall.

\section{QUESTIONS}

What is a rotation of crops? What crops do the people grow in rotation in England? II as the rotation been very beneficial in that comtry? What is a good rotation of common crops for the southern States? Why is this a good rotation? What effect does it have on land to grow cotton constantly on it? Can fertilizers be used profitably in rotation? Why would you not fertilize peas or peanuts with fertilizers containing nitrogen? With what would you fertilize peas? What Experiment Stations have succeeded well with a threeyear rotation? Would following this rotation require one to put 
all of his farm in one crop each year? What crop may be used to advantage on the lime lands of Texas? What crop might take the place of oats in rotation? Why do rice farmers have to stop growing rice for a year or more now and then? What conld be done with the rice land to advantage when it is lying out?

Experiment. - Get your father to rotate his crops on a small piece of land as an experiment, if he does not do so regularly. 


\section{CHAPTER XIV}

\section{MANURES AND FERTILIZERS}

Value of Bones. - About seventy-five years ago a German chemist named Liebig analyzed plants and found out what they contained. By experimenting, it was learned what ingredients the plants are unable to get in sufficient quantity from poor land, and attempts were begun to compound suitable mixtures of fertilizer ingredients. Liebig was perhaps the first chemist to teach that bones, being rich in phosphoric acid and fairly rich in nitrogen, are good fertilizers. He afterwards wrote, bitterly complaining that, after he had taught the Englishmen the value of bone as a fertilizer, they had robbed the battlefields of Waterloo, Leipsic, and the Crimea of a hundred thousand tons of bones to enrich their fields.

Guano and Composts. - Peruvian guano, a bird manure of certain rainless South American islands, was the first concentrated commercial fertilizer used in this country. It was used in the older cotton states from just after the war between the states until about 1880 , when the supply was mostly exhausted. About 1870, David Dixon, of Georgia, made composts, or mixtures of guano, manure, leafmold, salt, and other things, and let them lie for some time in large moist heaps, and then applied in the cotton row before planting. He raised enormous crops 
of cotton, and accumulated a great fortune. It is probable the salt and some other things were useless. But a compost of commercial fertilizer ingredients with barnyard and stable manures or cotton seed never fails to give good results. It has been found, however, that putting the manure or cotton see in the furrow, sprinkling the commercial fertilizer on it, and then bedding on the mixture, does quite as well as first composting in a heap.

Phosphate Rock. - Rock, rich in lime phosphate, a compound of phosphoric acid and lime, is mined in Florida, Georgia, Tennessee, Arkansas, and in many other parts of the world. This rock is ground up by powerful mills into a fine powder called floats. As the phosphoric acid is not easily soluble in this form, the porder is mixed with sulphuric acid. This sulphuric acid combines with part of the lime, leaving the phosphoric acid in a condition to dissolve in water and to be used by crops. The floats, thus treated with sulphuric acid and dried, are called acid phosphate or superphosphate. This acid phosphate is the largest ingredient in most commercial fertilizers. It. contains usually fourteen to sixteen per cent of pure phosphoric acid. The next prominent ingredient in commercial fertilizers is cotton-seed meal, which contains about seven per cent of nitrogen, three per cent phosphoric acid, and one and a half per cent potash. A little kainit, or other potash salt, found in Germany, is usually put into the mixtures. When containing nitrogen, phosphoric acid, and potash, a fertilizer mixture is called a complete. fertilizer. Nitrate of soda, which is mined in Chile and. 
contains about sixteen per cent of nitrogen, may be used in place of part or all of the cotton-seed meal. The nitrogen in nitrate of soda is more quickly available than that in cotton-seed meal. For early, quick-maturing crops, nitrate of soda should take the place of some of the cotton-seed meal. Dried blood or other slaughterhouse refuse and dried fish are also often used. The nitrogen in these is about as quickly available as that in cotton-seed meal. The dried fish is rich in nitrogen and phosphoric acid.

Where Potash is Needed. - It has been learned from

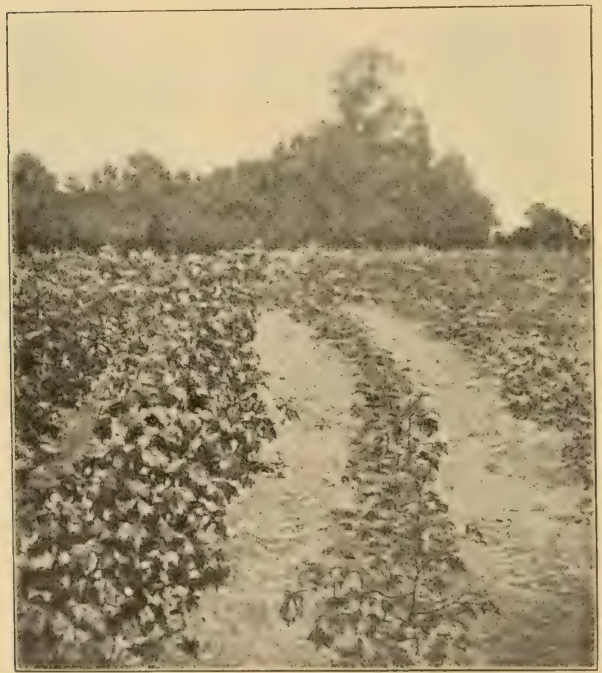

Fig. 35. - Fertilized and Unfertilized CotTon experiments that the soils of Mississippi, Louisiana, and Texas do not generally need potash. So no potash salt should be used in the mixtures for these states. In Georgia, the Carolinas, and Alabama, a little potash is generally found beneficial.

\section{Fertilizer Mix-}

tures. - Equal parts of cottonseed meal and acid phosphate mixed will make an excellent cotton fertilizer for old and worn lands. Such a fertilizer 
will contain about three and a half per cent of nitrogen and nine per cent of phosphoric acid, and about three fourths per cent of potash. For land not so badly worn or land that has been in pasture, or been lying out one or more years, 1300 pounds of acid phosphate and 700 pounds of cotton-seed meal, making a ton, would probably be better than the other meal-acid-phosphate mixture. For land needing potash about two hundred pounds of kainit should enter into each ton of mixture. Trale conditions now seem to warrant us in valuing nitrogen in fertilizer's at seventeen cents a pound, and phosphoric acid and potash at six cents a pound each.

Balancing Manures. - Barnyard and stable manures are not well enough balanced without some additional phosphoric acid to give the most valuable results on most of the thin lands of the cotton states. If every load of manure had a hundred pounds of acid phosphate added to it, the results would be better, and it would go much farther. Manure, as a rule, is much richer in nitrogen and potash than in phosphoric acid. Experience has shown that for most sections a fertilizer should be richer in phosphoric acid than in anything else.

Rich Food makes Rich Manure. - The quality of fresh animal manures largely depends upon the kind of food the animals eat. No food eaten by animals loses much of its fertilizing value by passing through the animals. The manure made from feeding cotton-seed meal will never contain less than seventy-five per cent as much fertilizing value as the meal had, and it may contain as much as ninety per cent. Manure made from feeding cotton seed 
will be richer than that from feeding corn, because cotton seed is richer than corn.

The liquid manure from well-fed cattle will contain half or more of the total fertilizing value of the feerl. From cattle eating mostly coarse food, the liquid will not contain so much of the fertilizing value.

In order to save the liquid manure properly in stables, bedding for the cattle should be provided so as to absorb and hold it.

As has been said before, if animals are allowed to tramp the manure down in the stables, its value will be preserved better than in any other way, unless it be applied to the land and mixed with the soil from day to day.

Value of Manure. - A dairy cow, well fed, will produce ten cents' worth of manure a day, if the plant food is rated at the same price that has to be paid for it in commercial fertilizers. A horse well fed on oats and grass hay will produce nine or ten cents' worth a day, but of course not all of it will be dropped in the stable. If the horse is fed on peavine, peannt, or alfalfa hay, the manure will be worth more. Your past lessons have taught you why this is so. Immense losses occur every year on account of the poor way in which farm manures are handled. In fact, on most farms no attempt is made to save and use them.

A ton of cotton seed has about the same plant food that a thousand pounds of cotton-seed meal has. The meal rots quicker, and is perhaps better for quick-growing crops. As the seed supplies more humus to the land, it. will give results the second and third years after using. 


\section{QUESTIONS}

Who was the first man that analyzed plants? What complaint did he make against the English people? What was the first concentrated fertilizer used in the United States? Tell about David 1)ixon's first experience in using this concentrated fertilizer. Where is the phosphoric acid of fertilizer obtained? How is phosphate rock treated? What is the name of the product made from phosphate rock? What is generally mixed with it? What may take the place of cotton-seed meal in fertilizer mixtures? What is meant by complete fertilizer? What advantage has nitrate of soda over cottonseed meal as a fertilizer? What other materials are rich in nitrogen? What states appear to need no potash added to their soil? What states appear to need some potash in their fertilizer mixtures? Name a suitable mixture of acid phosphate and cotton-seed meal for cotton to be grown on worn land. What may be added to barnyard manure to make it more valuable? What fertilizer ingredient should nearly all fertilizer mixtures be richest in? Is very much fertilizing matter lost from feed stuff by being eaten by animals? Which will produce richer manure when fed to animals, corn or cotton seed? Which will produce richer manure when fed, peavine or Johnson-grass hay? How much cotton seed will equal a ton of cotton-seed meal in fertilizing value? Which will have the most lasting effect when used as a fertilizer, cotton seed or cotton-seed meal? Which will give the quickest results?

Experiment. - Manage to get a few rows of cotton and corn on the farm at home fertilized with cotton-seed meal, a few rows with acid phosphate, and a few rows with kainit, using all fertilizers at almost the rate of one hundred and fifty pounds per acre. Watch growth of crops carefully and if possible weigh and measure yields. Then use a mixture of meal and phosphate, a mixture of meal and kainit, and a mixture of phosphate and kainit in the same way, and also note results. See if the author is correct about the kinds of fertilizers needed.

Try fertilizing peas or peanuts with cotton-seed meal, with phosphate, and with kainit in the same way. Report results to school next year. 


\section{CHAPTER XV}

\section{COMMERCIAL FERTILIZERS}

Large Use of Fertilizers. - The use of commercial fertilizers has grown enormously in a few years. Georgia used in 1907 perhaps $\$ 15,000,000$ worth and used them profitably. Texas used perhaps less than 20,000 tons, yet Texas probably has more land suited for using such fertilizers profitably than Georgia has. Arkansas and Oklahoma also have much of such land. Practically all of the timber belts, most of the coast prairies, and much of the sandy and loamy lands in the red-land sections in Louisiana, Arkansas, Oklahoma, and Texas would probably readily respond to commercial fertilizers. The lime lands and the dry lands of the West are generally too rich for ordinary amounts of commercial fertilizers to be used on them with profit.

Valuing Fertilizers. - A mixture of 1200 pounds of cotton seed and 800 pounds of acid phosphate to the ton makes a good fertilizer.

This mixture contains about 36 pounds nitrogen, worth $\$ 6.12$, about 126 pounds phosphoric acid, worth $\$ 7.56$, and about 20 pounds potash, worth $\$ 1.20$. Total value, $\$ 14.88$ per ton.

Of the meal and acid phosphate mixture first named on page 94, 2000 pounds contain:- 
70 pounds nitrogen@.17

180 pounds phosphoric acid@.06 10.80

15 pounds potash@.06

Total value per ton,

$\frac{.90}{\$ 23.60}$

For Georgia, Alabama and the Carolinas 1200 pounds phosphate, 700 pounds cotton seed meal, and 100 of muriate or sulphate of potash are often recommended; also 1000 pounds phosphate, 700 pounds meal, and 300 pounds kainit. Kainit contains 12\% of potash, and muriate and sulphate about $50 \%$ of potash.

Nitrate of Soda. - The nitrogen in nitrate of soda acts more quickly than that in cotton-seed meal. All plants need fertilizers when young. So a mixture probably better than the last one named would be 1400 pounds acid phosphate, 400 pounds cotton-seed meal, and 200 pounds nitrate of soda to the ton. Or, for badly worn land, 1200 pounds acid phosphate, 600 cotton-seed meal, and 200 nitrate of soda. Where whole seed are used instead of meal, 1000 pounds seed, 850 pounds acid phosphate, and 150 pounds nitrate of soda are recommended. For quick-growing crops like early truck crops a still larger proportion of nitrate is recommenrled.

Richness of Mixtures. - The different fertilizer mixtures which contain cotton-seed meal and cotton-seed meal and nitrate of soda are all richer than the average fertilizer which is sold for cotton. One hundred and fifty pounds to the acre are about equal to 200 pounds of ordinary cotton fertilizer. These mixtures are about as rich as most of the so-called vegetable fertilizers, 
except that the latter usually have a large amount of potash.

Do Fruits need Large Proportions of Potash? - It has been generally supposed that fruits and vegetables need larger proportions of potash than ordinary field crops do; but from what would seem conclusive results in Lonisiana, Mississippi, and Texas, potash is not profitable to use for any crop on any soil yet tried in these states. 'There seems to be no proof anywhere that fruits and vegetables need a larger proportion of potash than corn or cotton. The kind of land more than the kind of crop seems generally to determine the kind of fertilizer. For wellknown reasons this statement does not apply to leguminous crops and their nitrogen supply. Tobaceo needs a larger proportion of potash than most crops, as its ash contains a very large amount of this ingredient.

Proportions of Plant Food in Mixtures. - The Southern manufacturers and users of fertilizers, in mixing their materials so as to contain two per cent of nitrogen, eight per cent of available phosphoric acid, and one and a half to two per cent of potash (or in about those proportions), seem to be much nearer the best practice than Northern manufacturers and mixers follow. Books have been written giving what are supposed to be the fertilizer needs of almost all crops, and the only basis for supposing the crops to need plant food in the proportions recommended seems to have been the analysis of the crops themselves. Analysis shows that nearly all crops contain more potash than phosphoric acid. That is no inclication that fertilizers for such crops should contain more potash than 
phosphoric acid. Almost all lands are richer in potash, generally three to four times as rich. From the bestknown chemical means of determining available plant food, there are many times as much available potash in average soil as there is phosphoric acid.

Many of the largest fertilizer companies in the country are putting more potash than phosphoric acid in their fertilizers. Such practice is, without doubt, causing the loss of millions of dollars annually.

Experiment Necessary. - Only actual field trials with crops will afford proof of what they need on different soils. The experiment stations of the country have made the most reliable literature of agriculture we have, and their results clearly show that, with rare exceptions, crops need much more phosphoric acid than potash in fertilizers, and in much of the country the latter is not needed at all. In nearly all cases, the kind of land instead of the kind of crop should decide which one of these elements is most needed. A slightly worn, muck land in Illinois and the neighboring states needs only potash to make it productive again. Very poor sandy land in Florida needs potash, but still more phosphoric acid and nitrogen. Some land in Mississippi and the states west of the Mississippi River probably need potash - particularly deep sandy land. Farmers should make some tests for themselves.

Stimulating Effects of Fertilizers. - Many people ask if commercial fertilizers do not have a stimulating effect, and if they do not wear out the land.

It is true that 100 pounds of fertilizer will often increase the cotton crop 500 pounds of seed cotton to the acre. 
This cotton, together with the seed, contains more plant food than the fertilizer contained, notwithstanding some of the latter is always washed away. The explanation is that the fertilizer causes a strong growth of root that enables the crop to get more plant food out of the soil than it would get otherwise. To that extent fertilizer wear's the land. But if we can get the plant food in the form of valuable cotton, we shall be more than repaid for the wearing of the land.

Effects Permanent. - By using reasonable amounts of fertilizers with coar'se manures and cotton seed, or with suitable rotation of crops, lands are steadily and permanently enriched. We have abundant evidence that where large quantities, say from 800 to 2000 pounds to the acre, are used for vegetables, such as cabbage or Irish potatoes, and these crops are followed the same season by cotton or sweet potatoes, the land grows better from year to year.

Where Fertilizers Pay. - Fertilizers seem to pay best on land which is sandy enough to drain perfectly, and which, at the same time, has a good percentage of clay in the subsoil. Such are the long-leaf and short-leaf pine, oak, and hickory lands of the Southern States. Also much of the coast prairies and practically all of the postoak timber lands of Texas and Louisiana are of this eharacter. For staple crops, fertilizers seem to pay best on land naturally rather poor in plant food, making at best less than half a bale of cotton to the acre. The author has frequently seen moderate applications fail to show any good effects on land fertile enough to yield two thirds of a bale of cotton. 
For vegetables, large applications of fertilizer on land of almost any character will generally pay. Fertilizers have generally been unprofitable on lime land. These lands have such large stores of plant food that they only need to have their physical condition improved. Rotation of crops, coarse manures, pasturing, etc., will make available enough of their own food to restore their former productiveness. The Alabama Experiment Station, however, did find that large applications of commercial fertilizers, containing an abundance of nitrate of soda, paid well on well-drained, worn lime land. Nitrate of soda used in side furrows during cultivation also gave good results in frequent trials at that station.

Method of applying Fertilizers. - Barnyard manure is generally spread broadcast on the land, while commercial fertilizers are usually applied in the drill before planting. For cotton, the fertilizer is generally sprinkled in a furrow and bedded on.

Experiments have well demonstrated that all manures and fertilizers give better results if they are strewn in the drill, or under the drill, where the crops are to be grown. It used to be thought that it was best to put fertilizers very deep in the ground. The Louisiana Experiment Station and others have proved that probably it is better to use them about the depth of the seed or a little deeper. The Georgia Experiment Station got better results by bedding on fertilizers than by putting them in the furrow with the seed. It has been believed that some of the fertilizers should be used at or before planting, and some in side furrows during the cultivation of the crop. 
Where moderate amounts of fertilizers are used for cotton, all experiments indicate that it is a little more profitable to use the full amount just before or at planting time. It has often paid to use part of corn fertilizer at the second cultivation. Nitrate of soda applied during the cultivation of cotton has proved to be profitable in a number of experiments.

\section{Amount of Fertilizers to Use. - It has been proved by} all experiment stations that small applications of eoncentrated fertilizers, say 100 to 200 pounds to the acre for cotton, pay a larger percentage of profit on the cost of fertilizer than larger applications; but larger applications, 300 to 400 pounds, or even 600 pounds, often pay a bigger profit to the acre. It is always unprofitable to use too large an amount.

It appears to be well established that land badly worn, and having little humus, will give good profits on only small applications of fertilizers. The land seems not to hold water enough to support a large crop. It follows that land in good condition from rotation of crops, pasturing, being allowed to grow up in weeds, or plowing under coarse manure, will supply water for a big crop, such as a large amount of fertilizer ought to produce.

Every farmer should, by careful observation, find out just how much fertilizer it will be profitable to put on his land. From three to ten times as much fertilizer is often used on Irish potatoes, cabbage, onions, and other vegetable crops, as on cotton or corn.

Fertilizers almost always pay better on cotton than on corn. 


\section{QUESTIONS}

Give an example to show how large the trade in commercial fertilizers has become. Should fertilizers be used more largely in Texas than at present? What lands in Texas would probably gire profitable results with commercial fertilizers? What amounts of cotton seed and acid phosphate mixed would make a ton of good fertilizer? What are nitrogen, phosphoric acid, and potash valued at in fertilizers? Would you use a larger proportion of cottonseed meal on badly worn land than on better land? Why would some nitrate of soda be of advantage in every fertilizer mixture? What are the vegetable fertilizers, generally sold, rich in? What was the belief about commercial fertilizers wearing out land? What mistakes are made by some Northern manufacturers in mixing fertilizers? Do commercial fertilizers wear out the land? Do large amounts of fertilizers improve the land rapidly? Do small applications of commercial fertilizer pay better on rich land or poor land? What kind of crops, if any, need the highest percentage of potash in their fertilizers? Tell about fertilizing lime land. What is usually the hest treatment to make lime land productive? Are fertilizers and manures most effective when spread broadcast over the land or when used in the row? How deep has it been found necessary to put fertilizers in the ground? Has it been found profitable to use part of the fertilizer before planting and part while working the crop? Which pays the better, a small application of fertilizer or a large application? Why can large applications not be used profitably if the land is very badly worn? How much more fertilizer is generally used to the acre for cabbage and onions than for cotton and corn? 


\section{CHAPTER XVI}

\section{PLOWING}

Subsoiling. - Plowing is the primary operation of the farm or the garden. Yet people hold very different opinions as to how it should be done. All the older agricultural literature advised that the deeper plowing could be done the better on all classes of land and for all kinds of crops. This same opinion seems to be held by many agricultural writers even now. Subsoiling, particularly following a turn plow with a bull-tongue, running deep in the same furrow, so as to loosen the subsoil twelve to eighteen inches deep, is frequently recommended.

The Georgia Experiment Station tried subsoiling on perhaps hundreds of plots of land for some ten years or more, but the crops were never any better than those that received ordinary plowing. The Mississippi Stations, two of them, thoroughly tested subsoiling on different lands, for different crops, and at different seasons of the year. The crops were never increased over those made on lands plowed in the usual way.

The Kansas Experiment Station tried subsoiling for many years, but the yield of the crops was never increased. The experiment stations of many other states, including Texas, have been similarly disappointed in sub- 
soiling. It is expensive to subsoil land, and if it does no good, it should not be recommended. The truth seems to be that there is very little land where subsoiling pays. Many farmers have reported good results from subsoiling, while others have reported no results, and still others, injury from it.

Depth to Plow. - There is a difference of opinion among people who do not subsoil land as to how deep it should be broken in its preparation. Doubtless different soils and different crops should influence the depth of preparation, if their requirements could be definitely known. The Alabama Experiment Station for a number of years subsoiled some land and broke other pieces to depths varying from three and one half to six and one half inches. The subsoiling did not pay for either cotton or corn, and the different depths for breaking did not seem to give any marked difference in crops. One depth yielded most one year, and another depth yielded most another year. The different depths of breaking averaged about the same yield for both corn and cotton. The Indiana and Oklahoma stations tried eight-inch plowing against four-inch for many years, and generally did not get increase enough in yield to pay for the extra work of breaking deep. Every farmer should make some tests for his own land.

The Texas Experiment Station planted sorghum on one piece of land subsoiled fifteen inches deep, on another plowed five inches deep, and on still another plowed three inches deep. That broken five inches deep yielded much more than either of the others. The subsoiled piece made 
a little more than the piece broken three inches deep. So it would seem that breaking the land or bedding it an ordinary depth is best, and we know it is cheapest.

Deep Plowing for Cane. - In Australia and Hawaii, deep breaking and planting have proved best for sugar cane, but it is probable that the deep planting serves to keep the tall tropical cane from falling down, and that it yields more on this account. Many experiments at several experiment stations in Australia failed to give any good results for especially deep breaking for other crops.

H. W. Campbell, who has won something of national fame on account of the results achieved in farming semiarid land, claims that it is far more important to compact the soil plowed and make it thoroughly fine than to plow it deep. He recommends plowing from three to seven inches deep, according to the conditions, compacting again, and then working up a fine mulch of surface soil about three inches deep. In a conversation with the author, Mr. Campbell said that it would be well-nigh impossible to compact land plowed twelve inches deep so as to get it again in good condition for drawing up moisture from the subsoil.

Purposes of Plowing. - Plowing serves to bury trash and manure, to make a seed bed, to conserve moisture, to kill weeds and grass, to allow air and water to enter the soil better and promote chemical changes, to allow roots of crops to grow better, etc.

All farmers' boys and girls know a plow and its different parts. If not, they should ask their fathers and neighbor's about these things. 
Black-land and Sandy-land Plows. - A plow is a sort of twisting wedge. The more twisting the wedge the more it turns the soil and the more it pulverizes it, but the harder it is to pull, and the poorer it will scour in black or stiff soil. The straighter and more tapering the moldboard, or wedge, the easier it will be to pull, the less it will turn and break and crumble the soil, the

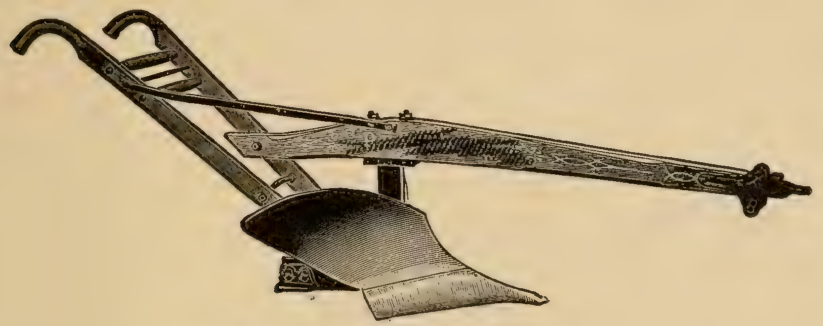

Fig, :36. - SANdy-tand Plow

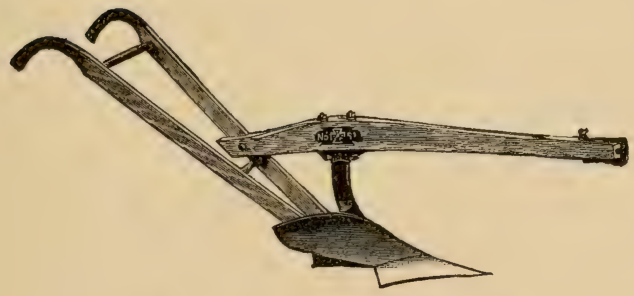

Fig. 37. - Black-Land Plow

brighter it will keep, and the better it will work in stiff and black land. Figure 37 shows a good type of a blackland plow, also suitable for any stiff elay soil. Figure 36 is a good picture of an ordinary, or sandy-land plow.

Sandy-land plows are apt to choke and cake on black land. The black land may be broken up cloddy, but as 
explained before, the lime it contains soon causes the clods to melt down into little shotlike particles. This is also true of much of the bottom land.

Killing Bermuda Grass. - It is often advisable to use a black-land plow in sandy sections. To kill Bermuda grass where it has been pastured, the sod should be broken in the fall or winter about three inches deep with a small black-land plow, going at such speed and held in such a mamner that the furrow slices will be turned on edge. This causes the grass to freeze and die. On pastured land, the underground stems of this grass have to come near the surface for air, and hence shallow plowing at the right season causes them to freeze. The land on which the Bermuda grass has been killed in this way is always rich and productive when brought back into cultivation.

Killing Johnson Grass. - Johnson grass may be pastured two years and killed by careful working of the land in cotton a year or two. The big fleshy runners, which go down so deep in cultivated land, come close to the surface when pastured, and get small and weak. If, after being pastured, the land is broken in the fall and then thoroughly plowed again in the spring and worked well and late in cotton, the grass can be entirely killed. After the turf has been killed and rotted, the land becomes very productive.

\section{QUESTIONS}

What was the old idea with regard to plowing? What is subsoiling? What have the Experiment Stations found out about subsoiling? Is it definitely known how deep land should be plowed? 
What about plowing deep for sugar cane? What is the Camplell system of soil culture? Name some of the different purposes for which plowing is done. How may a plow be compared to a wedge? What sort of plow should be used in black land? Which will pulverize and crumble the soil most, a black-land plow or a sandy-land plow? What would happen to a sandy-land plow if used in sticky black land? How would you kill Bermuda grass? Could you kill Johnson grass in the same way? In what condition is the land after killing Bermuda grass? Explain why this is so. After killing Johnson grass, what condition will the land be in? What effect will the rotting of any grass, weeds, or other vegetable substance have on the land? 


\section{CHAPTER XVII}

\section{PREPARATION FOR PLANTING}

Bedding or Flat-breaking. - As to whether land should be broken flat or thrown into beds is a question which depends on the character of the land, the kind of crop, the season of the year, and the amount of moisture in the soil. On sandy soil in the West it would be undoubtedly a fine plan to plant corn in the bottom of a lister, or "buster," furrow, either with a planter attachment or with a drill to follow after the lister. In case you don't know what a lister is, get some good farmer to show you one and explain it to you. By planting the corn in the bottom of the furrow on hard ground, it will be sure to get enough moisture to come up. Your father will tell you that cotton, wheat, or clover planted in well-settled, firm ground, will come up much better than in freshly made, loose ground. Hard, firm land can draw up moisture from below. A fresh, loose bed, with seed planted far above the firm ground, is something like a lamp wick cut in two between the flame and the oil. The seed camnot get enough moisture to come up. When the young corn is in the bottom of a furrow with ridges of loose dirt in the middle, the dirt can be gradually worked to the corn, and little weeds and grass can be covered at each working. The corn, when deep rooted, 
is better able to endure drought and to stand up in the storms. Cotton in some cases might also be worked in the same way, but when young, it is a more tender plant than corn, and it is more likely to need starting on a small bed or on level ground, even in dry sections.

In Eastern or Southern States, land must be very sandy, or the planting must be late, to justify planting in lister furrows. Generally, on clay or bottom land, early cor'n and cotton are both planted on berls for the sake of getting sufficient drainage to secure good stands. Corn is sometimes planted on beds eight feet wide, two rows being planted on each bed. This gives clrainage on one sicle of each row of corn.

Bedding with Lister. - One of the best and cheapest ways to bed for cotton is to use a lister. The old rows should be broken out in the fall, winter, or early spring. This will make beds in the old middles. Then if, some time before planting, these beds are burst with the lister, the beds for planting will be where they were the previous year. This preparation is much cheaper than bedding and re-bedding with a turn plow, and so far as we know, is quite as good. If fertilizer is used, it should be sprinkled in the middles just ahead of the lister when the land is being re-bedded, so that the beds will be over the fertilizer, or else the fertilizer should be put in the furrow at planting time. In the drier districts the earlier and deeper application of fertilizer is best.

Fall or Spring Breaking. - There has been much experimenting done to determine whether fall or spring breaking of land is best. In a majority of cases in the humid 
sections of the South, land broken in the spring has procluced as good crops as that broken in the fall. Even where pea vines have been grown, plowing the dead vines under the next spring has done quite as well as plowing them uncler green in the fall. Some believe that cropss

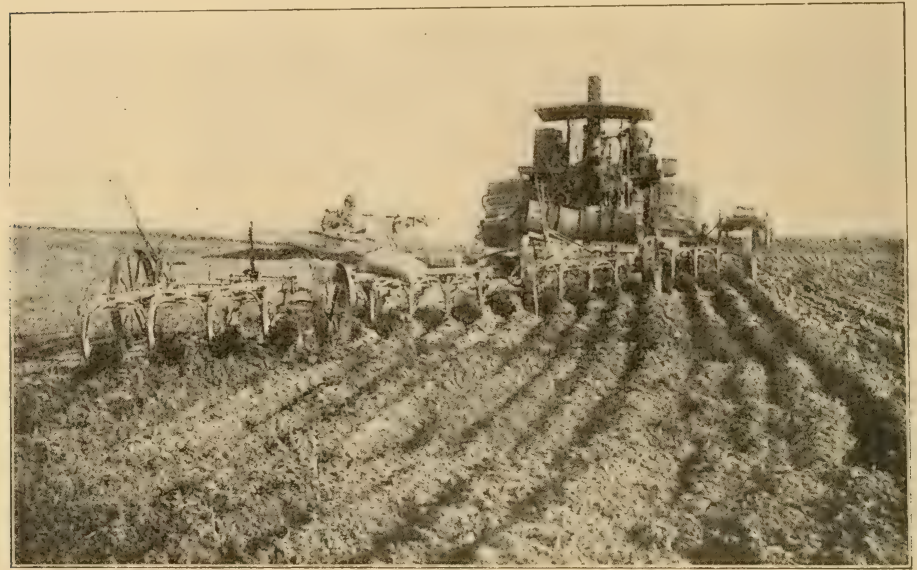

Fig. 38. -- Stean Plow on the Plins

turned under when very green form acids that are hurtful to future crops.

It has been said that tillage is manure; that is, tillage enables the earth, air, and moisture to form soluble plant food. This is true, and hence we should till or plow little in a warm, wet country, unless we have crops growing or soon to he started that will take up and use this plant food, and prevent its being leached and washed away.

Where moisture is scarce, as in the western part of Texas, Oklahoma, and Kimsas, fall plowing would un- 
doubtedly pay. (One of the things to be feared so far west, where it rains little in winter and early spring, is that there will not be moisture enough to bring up early crops. Plowed land in arid or humid climates, summer or winter, always contains more moisture than unplowed land. One of the disadvantages of clay or bottom land in humid climates is that, if plowed in the fall, it holds so much moisture that it cannot be planted early in the spring. Usually land that has not been plowed in the fall can be bedded and planted in the spring before a team can stand on the fall plowed land without bogging. The trouble is still greater if the land is subsoiled in the fall.

Much land is of such a nature that if plowed in fall, it compacts again and requires just as much preparation the following spring. Lime lands, heavy bottoms, grass sods, and lands having large amounts of weeds and trash, are most likely to be benefited by fall or early winter plowing. Fall plowing is often advisable to destroy insects, such as boll worms, cut worms,

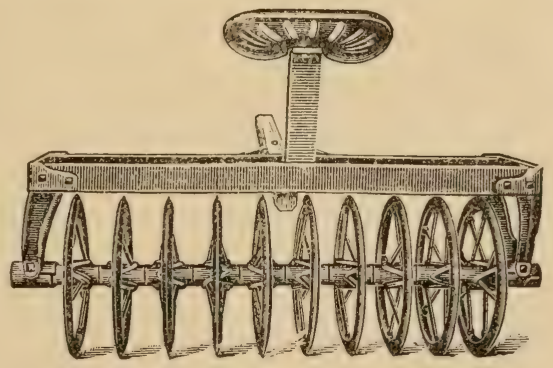

Fig. 39. - Sub-Surface Packer. etc., and to kill cotton stalks, so as to deprive the boll weevil of food.

Plowing Land when Wet. - Ordinary types of land such as clays and loams are very likely to be injured when plowed too wet, especially in late spring. It does 
not hurt light sandy lands, lime lands, and the buckshot lands of the bottoms to plow them wet, because the clods that are formed crumble easily. It probably would not hurt any land to plow it wet, if it were not that in dry weather the clods become very hard. The rice land of China and Japan is all plowed in the water, but owing to the fact that the land is kept wet by irrigation, it continues to make good crops, as it has done for ages.

Plowing for Fall Seeding. - Any kind of land in which small seeds, like alfalfa, turnips, rape, ete, are to be sown in the fall, should be broken early in summer, if possible, and kept clean of weeds by harrowing and disking till planting time. Such land will be much more moist than the land that grew a crop of grass or weeds until late in the season. All kinds of plants, as we have seen, draw heavily on the water of the soil. When two crops of Irish potatoes are to be grown on the same land in one year, the land should be well plowed and kept clean, from the time of digging the early crop until planting time of the second crop. In no other way, without irrigation, can land be kept moist enough in most seasons to bring up and grow a fall crop of potatoes.

Working Crops. - Cultivation of growing crops is given to kill weeds, to form a dirt mulch, to prevent too rapid evaporation of moisture, and to stir up the soil to almit air and cause rapid formation of soluble plant food in the soil. It is often alvised that cultivation should always be shallow - from one to two inches. Hundreds of experiments have been made cultivating all depths to five and six inches. Results have been very conflicting. 
Three inches deep has perhaps averaged better yields than deeper or shallower cultivation. This is about the depth run by single sweeps so largely used for cotton in the South. A safe rule would seem to be tọ cultivate the most convenient depth for destroying weeds and grass.

Cultivation may be given too often as well as too seldom. For staple crops, 'cultivation each twelve to fifteen lays gives about as good results as more frequent working. Where drought is feared, it may pay to work oftener to break a crust formed by hard rains.

\section{QUESTIONS}

Would you plow land in ridges or beds, or plow it level? How may corn be planted to adrantage in dry sections? What is the difficulty sometimes experienced in planting cotton on fresh, loose leds? Why is it better to plant on land that has had time to settle and pack hy rain? If corn is planted in the bottom of a lister furrow, can it be worked cheaper? Why do we plant on beds at all? Explain how a lister is used in bedding land for cotton. Explain how fertilizer is applied. Which has proved better, breaking land in the fall or in the spring? II as it been found best to plow pea vines under when green, or to wait until they are dead? In what part of the country would you always plow land in the fall? Which will always have the more water in it, plowed land or unplowed land? In the humid sections do you have too much or too little water in the early spring? Which can you plant earlier in spring in humid sections, fall-plowed or springplowed land? What classes of land will do best for fall plowing? Is it ever advisable to plow in the fall to kill insects? What kinds of land may be plowed wet and not be injured? Why will it injure clay land to plow it wet? How do the Chinese and Japanese manage to plow land wet without injuring it? If you wanted to get a stand of alfalfa in the fall, how would you treat the land? How would you treat land to grow a fall crop of Irish potatoes?

Experiments. - Get your father to plow a few rows twelve inches deep, and a few rows about three or four inches deep, and plant both 
alike. See if there is any value in subsoiling. If you can't get this done, spade a small piece of ground twelve inches deep and another three or four inches; plant and observe results. Let the whole school know result next year.

Plant at school or at home a few seeds in two boxes of soil. IIave soil rather dry, and plant seeds in quite loose soil in one, and in the other pack the dirt well after planting and then loosen soil abores seed. See what difference in the germination of the seed. This can be done at school.

In the time of drought take off the top soil on well-cultivated lamr on the farm and get a little box of subsoil, closing it up tight. 'Take some subsoil from a hard-packed weed patch near by and close it u' in a can or box. Weigh each one and then see how much water you can dry out of each one.

Observe whether fall plowing enables your father to plant earlier or later in spring, and whether it helps or hinders early growth of plants.

Wet some clay in boxes and stir one while wet, and then let it dry in the sum and note effect. Stir the other when it is moderately dry and note difference. This is a suitable school exercise. 


\section{CHAPTER XVIII}

\section{IRRIGATION}

Watering Rice. - The importance of irrigation camnot be overestimated. It is absolutely essential to make ricegrowing profitable, and to make other kinds of farming possible in many sections. The fact that when arid lands are irrigated, they at once become highly productive and lasting in their qualities, has already been referred to. In the rice-growing districts, large pumping machinery is used, sometimes raising a hundred thousand gallons of water a minute. This water is raised a few feet from the large rivers, creeks, and bayous, and emptied into broaci, shallow canals, some of them a hundred feet wide. The water flows along these canals a little higher than the surface of the flat rice lands that are to be watered. Smaller canals take water out of the big ones, and still smaller ones take it out of these and distribute it to the fields. By the time the big canal flows a few miles, and has had half its water taken out by laterals, or small canals, the water has become too low to flow out, and another pumping station is put in to raise the water a few more feet into a canal made with higher banks.

Storing Water. - In the mountain states, millions of dollars have been spent to build large concrete dams, sometimes a hundred feet high and a mile long, across canyons or stream beds. 'These dams sometimes make lakes many 
miles long and two or three miles wide, and the lakes hold water enough to irrigate one hundred thousand or more acres of land. The United States Government is putting in a large number of these big storage reservoirs in the II est. By wise laws, the money derived from the sale of public lands in the districts to be irrigated, is used for building more dams, catching more water, and reclaiming more rich, semidesert land. It is confidently believed that eventually all the flood waters now flowing down the Missomri, Arkansas, and other rivers, will be stored and held for summer irrigation. When this is done, there will be no more langer of the great levees of the Mississippi River breaking and flooding the rich delta country through which the river flows. These are vast undertakings, but our country is great and rich, and our people are enterprising and daring in developing its natural wealth.

Small Reservoirs. - There are thousands of small streams and canyons that may be dammed by individuals or small companies, where water enough may be stored to irrigate from a few acres to several thousand acres. It may be said that small reservoirs may be made at less expense to the acreage reclaimed than in the case of larger ones.

Irrigation in Humid Sections. - The possibilities for irrigating profitably in the humid sections have been particularly neglected. Nearly every crop in every section suffer's more or less from drought at some time. Much rain falls in Mississippi, yet the author has seen the profits on strawberries increased by irrigation as much as a humcled dollars to the acre. A Louisiana truck raiser, by irrigating during a drought, made two hundred 
and fifty crates of cabbage to the acre, while the best yield made by any neighbor was one hundred and fifty crates. The Wisconsin Experiment Station, situated in a humid climate, pumped water from a depth of twenty-six feet for irrigation, and burned coal costing five dollars a ton to do the work. The increased yields averaged about forty per cent on the different crops irrigated over those that were not irrigated. The net extra profits made to the acre one year, by means of irrigation, after paying for pumping and distributing the water, were as follows:-

$$
\begin{aligned}
& \text { Hay . . . . . } \$ 20.60 \\
& \text { Corn . . . . . } 11.18 \\
& \text { Potatoes . . . } 73.12
\end{aligned}
$$

Water Reservoirs. - Water can be found in abundance in many humid sections, and may be got cheaply on the land itself. Small streams often flow through the land, and these may be dammed up and made to flow over it by gravity, or the water may be raised by pumping. In the clay or lime districts where lasting streams are not plentiful, storage reservoirs can be easily made by damming stream beds, or hollows. In nearly all the large valleys of streams, and on low-lying lands near the seacoasts, overflowing artesian water may be had. Throughout much of the sandy and loamy areas of the country, large shallow wells afford water at depths of from ten to sixty feet, and the supplies may often be sufficient for irrigation.

Crops needing Irrigation. - Among the crops that with irrigation may be marle very profitable in the Southern 
States are sweet potatoes, sugar cane, and fall Irish potatoes. Sweet potatoes and cane do their best growing in September and October, when there is nearly always a deficient moisture supply. In fact, the states east of Texas are drier in these two months than the country

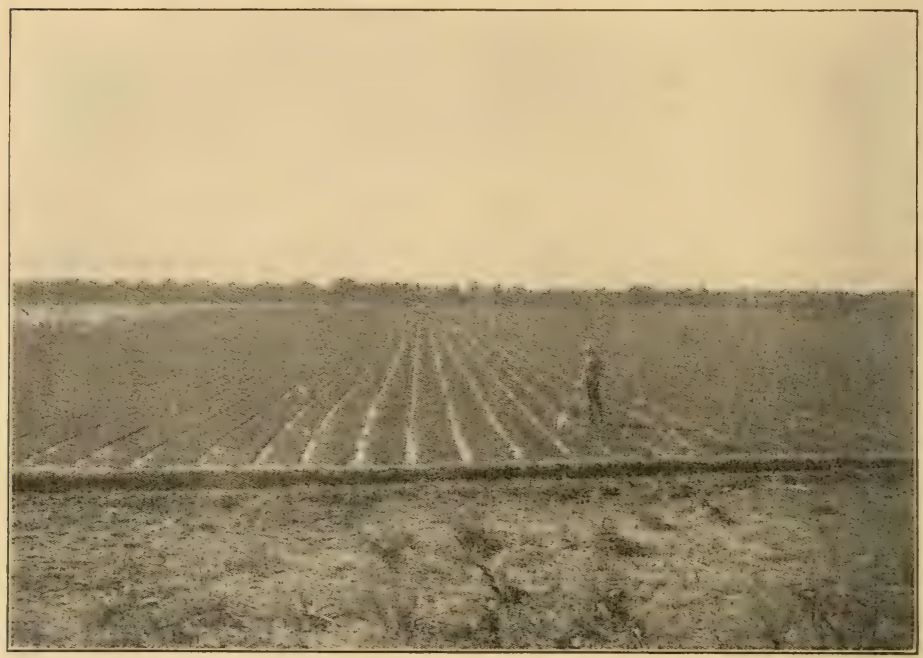

Fig. 40. - IrRigating Betwenn Rows

along the one hundresth meridian. With irrigation there is little doubt that a hundred bushels can be added to the yield of each acre of potatoes and one hundred gallons of sirup for each acre of cane. Cane and potatoes both grow in wide rows and on ridges; water can be easily applied to each crop, by causing it to rum along the middles between the rows. Whenever there is enough rain, the fall crop of Irish potatoes, planted about August in the Fulf States, makes quite as large and profitable a yield as the 
spring crop. On account of drought in April or May the early Irish potatoes scarcely produce a full crop one year in ten. There is no crop more easily injured by deficient moisture supply.

Mistakes in Irrigation. - A great mistake almost certain to be made by a beginner in irrigation is, that he tries to make a little stream of water, say ten to fifty gallons a minute, irrigate a large piece of ground. To make such a stream water even a quarter of an acre, troughs, hosepipes, etc., must be used, and that would make the labor of distributing the water cost too much to be profitable with ordinary crops. If one undertakes to run such a small stream along rows or furrows, it will lose itself perhaps in the first twenty feet. In order to r'm water along ditches and distribute it to the rows and over the land at a reasonable labor cost, at least two hundred gallons a minute should be at command. Such a stream may be let out of the ditch into several rows at a time, and the water will perhaps follow the rows a distance of a hundred yards. With this amount of water, one man can probably irrigate from one to two acres a day. With five hundred gallons' flow a minute, four or five acres a day can be watered. Another mistake where water is abundant is to use too much. Moderate applications of water followed by cultivation as soon as the land will work well will be found most profitable.

Storage Ponds. - Those who have small artesian wells or small pumping plants, should construct reservoirs a little above the level of the land to be watered, and should accumulate water and let it out in large volume when 
it is to be applied. A flow of fifty gallons a minute will accumulate about seventy-five thousand gallons of water in twenty-four hour's. This will afford a little over one and two thirds inches of water for an acre of land, a sufficient watering if it is applied in rows or furrows. In an arid country, when the land is very dry, as much as four inches may often be put on the land at one irrigation.

Distributing Water. - In distributing water over a field, the ditches must, of course, be kept on the highest ground. The rows, or furrows, to carry the water must be run at a suitable angle to the ditches, so as to have fall enough to run the water at a reasonable rate of speed, and at the same time not to wash the land. A little experience will enable one to give the rows the best fall on his particular kind of land. Head ditches should sometimes be one hundred yards apart and sometimes two hundred. Experience and common sense will be the best guides as to this.

In the arid country farmers sometimes flood the land somewhat as the rice farmers do, keeping water on the land just long enough to wet it thoroughly.

\section{QUESTIONS}

Tell about rice irrigation. What is the nation doing in the way of irrigation? What about farming in arid countries under irrigation? What profits from irrigation are possible in humid countries? What crops would probably respond profitably to irrigation? What amounts of water are necessary" What suggestions are made about eatching and storing water?" What mistake is a beginner apt to make at first in irrigation? 


\section{CHAPTER XIX}

\section{INSECT FRIENDS AND ENEMIES}

Losses Caused. - In 1907 the cotton boll weevil no doubt. destroyed, in 'Texas alone, a million bales of cotton, worth not less than sixty millions of dollars. When we consider the great number of harmful insects, we must conclude that the losses occasioned by them for the whole country are enormous.

Not all insects are harmful. IVe have seen how many of them, by carrying pollen and fertilizing flowers, make plants fruitful. Then we have the bee and many other useful kinds of insects. A little insect brought from the Old World made possible the Smyrna fig industry in California.

Insects destroy Other Insects. - Sometimes we can get rid of bad insects only by finding other insects that will destroy them. The great sugar industry of the Hawaiian Islands was threatened some three years ago by a little creature, called a sugar-cane leaf-hopper, that was introduced by means of seed cane brought from Australia. The government of the island territory hired a staff of entomologists and sent part of them to Queensland to find and send over the natural enemies of the hopper, while the others were kept at home to breed these imported insects and place them in the fields. In this way the cane industry was savel. When we camnot cope 
with an enemy of this kind, we try to find some brave little ally that will fight for us. We can keep up, in some cases at least, a sort of balance of power among our insect enemies.

Real insects have six legs and have their bodies in three divisions - the head, the thorax, and the abdomen. Grasshoppers, bees, wasps, ants, etc., are typical insects.

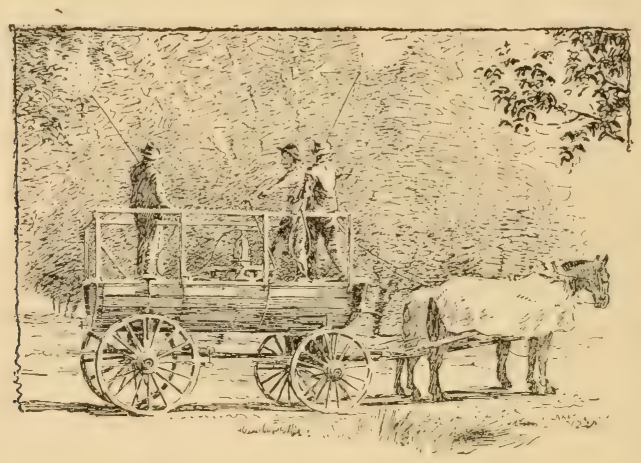

Fig. 41. - Spikaying Fruit Trees

Classes of Insects. - Insects may be divided into two large classes. One class, such as the grasshopper, the leaf worm, and the potato bug, for instance, bite and eat their foorl. These can be killed by sprinkling the plant with a very weak solution of Paris green, say a heaping teaspoonful to a bucket of water. In eating the leaves, the insect will get enough of the poison to cause its death.

The other class of insects are those that have tubes for inserting into the tissues of the plant and sucking the juices. Poisons will not kill these because they get none of them. The only way to destroy the sucking insects is 
to use some kind of spray that will burn their bodies. A worm, called the cotton boll worm, tomato worm, or corn worm, aceording to the kind of plant on which it is found, eats leaves at times and can be killed with poison, but after it has eaten into the ear, the boll, or the fruit, it cannot be easily reached by poisons.

Cabbage growers often use Paris green to kill the cabbage worm, but do not let their customers know it. Such applications are so small, and the poison is so nearly washed off by rain, that no person has ever been known to be hurt by eating cabbage treated in this way.

Killing Grain Weevils. _ Corn and pea weevils that infest our grains after they have been gathered can be easily killerl by placing the grain in barrels, boxes, tight bins, or tight rooms, and placing on top or near the top of the grain a cup or tin can containing a little bisulphicle of carbon, sometimes called "high life." This liquid evaporates and forms a gas heavier than air, and this gas sinks down through the grain and kills the insects. A teaspoonful to each two or three bushels of grain will accomplish the desired result. The gas soon passes off, and does not hurt the seed for planting or for other use. Weevils will get back in the grain later, and a new application will be needed.

Insects carry Disease. - One linul of Southern cattle tick carries the germs of the deally Texas fever from Southern cattle to Northern cattle. This will be discussed later. The dreaderl surra, which kills the horses of India, China, Java, and the Philippines, is carried by biting flies. It is now very well known that malaria, yellow fever, 
and dengue fever are carried from one person to another by different species of mosquitoes. In biting a person having malaria, the mosquito gets the germs of the disease, carries them away, and injects them into the next person bitten. Since the discovery of this great truth, people, by protecting themselves against mosquitoes, have good health even in the great river bottoms of the South. Typhoid fever is carried sometimes by the house fly. An insect called the tsetse fly of Africa carries the dreadful sleeping sickness of that country. It is quite likely that insects play a more important part in the carrying of the germs of human diseases than we yet know.

The Boll Weevil. - This insect pest came into Southwest Texas many years ago from Mexico, and has spread
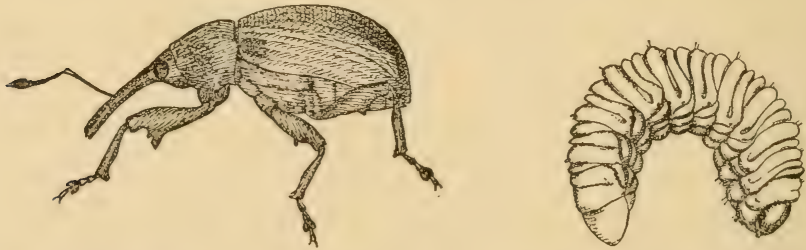

Fig. 42. - Boll Weevil (Mlignified) and Larva (Greatry Magimified)

eastward and northward till it has reached parts of Oklathoma, Arkansas, and Mississippi.

About first frost the grown weevils appear to go into winter quarters in timber, grass, weeds, and in any rubbish that may be convenient. The fact that weevils are always numerous in fields near forests shows that the woods afford them suitable places for hibernating, or living through the winter. 
The weevils begin to come out and hunt for food in

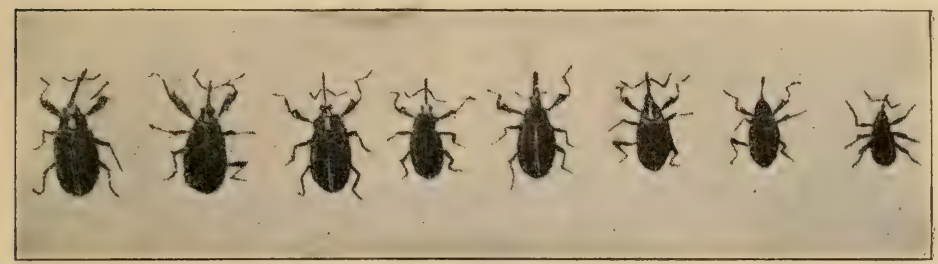

Fig. 43.-Different Life Sizes of Adult Weevils

April, and often continue to come out until late in June. The cotton plant furnishes their only food. Those that emerge early feed on the leaves and buds of the young plant until squares begin to form. After this they live by puncturing the squares with their long bills and sucking the juice. The females also puncture the squares in order to de-

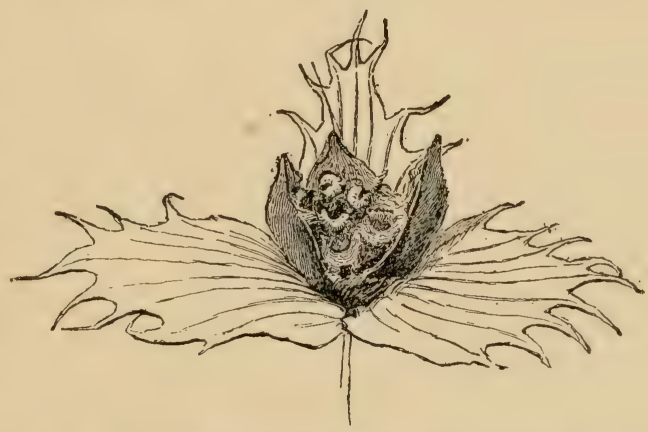

Fifi. 4t. - Puvitured Square containing YOUNG WeEviLS

posit their eggs. The egg soon hatches and produces a little grub (Fig. 44), which eats the inside of the little square and causes it to fall to the ground. In about eighteen or twenty days from the time the egg is laid in the square, the new weevil is old enough to begin laying eggs. This gives a new generation of weevils at least every twenty days. As each female weevil lays 
over a hundred eggs during her life, one pair of weevils will produce a vast number in one season.

Starving the Weevils. - It has been proved by Professor F. W. Malley of the Texas Experiment Station, and Dr. W. D. Hunter and others of the Department of Agriculture at Washington, that if cotton stalks are destroyed early in the fall, the weevils will have to endure a longer fasting period, and fewer of them will live till spring. It may be said that if all the cotton stalks were destroyed, so as to deprive the weevils of their food in October, probably only one per cent would live till cotton came up the following spring. If deprived of food in Novemher, perhaps three per cent would live through the winter, but if deprived of food in December, five or six per cent would live till spring. The cotton should, therefore, be picked as soon as possible, and all the stalks should be cut and burned. Perhaps an easier plan for many would be to turn cattle into the fields. Cattle will soon strip the stalks of all squares, bolls, and leaves, leaving the weevil nothing to feed on. This plan not only furnishes excellent grazing for cattle, but it preserves the fertility of the land much better than the burning of the stalks does. Unfortunately few people will burn their cotton stalks or allow their cattle to graze on them. As weevils are known to go as far as twelve miles from where they grew to maturity, the practice of burning or grazing the cotton stalks would have to be somewhat general in order to accomplish results that would be at all satisfactory.

Selecting early kinds of cotton, planting early, fertilizing liberally on poor lands, and working the crop well are 
the means that are chiefly relied on for raising cotton in spite of the weevil. By means of these methods, a sufficient number of bolls matures to make a fairly good crop before the weevils get numerous enough late in July and early in August to destroy all the squares and young bolls. Sometimes a full crop is made in spite of the weevil and other pests. As the average cotton stalk ordinarily makes six times as many squares as mature into bolls, most of the squares may be destroyed and still a sufficient number may be left to make as many bolls as the stalk can bring to maturity.

Fall Plowing. - Some people recommend deep, fall plowing as a means of planting early, and of getting the young cotton to grow rapidly. This is certainly the correct practice for the dry West Texas country, where the weevil first appeared, but clay and bottom lands farther east have too much water in early spring to permit very early planting and the most rapid growth of the young cotton. If plowed deep in the fall, this difficulty is only increased. If practicable, such lands should be handled in a way to make them get rid of water as rapidly as possible until about planting time. At that time there will be an abundance, if not an excess, and if the land is worked from then on so as to conserve moisture, every requirement of good agricultural practice will be met.

Destroying the Weevils. - Some people believe in dusting cotton with Paris green at the time the weevils are eating the young leaves before the squares appear. Most observers, while agreeing that some weevils are killed, do not agree that this is a pr... Stable practice. In the early 

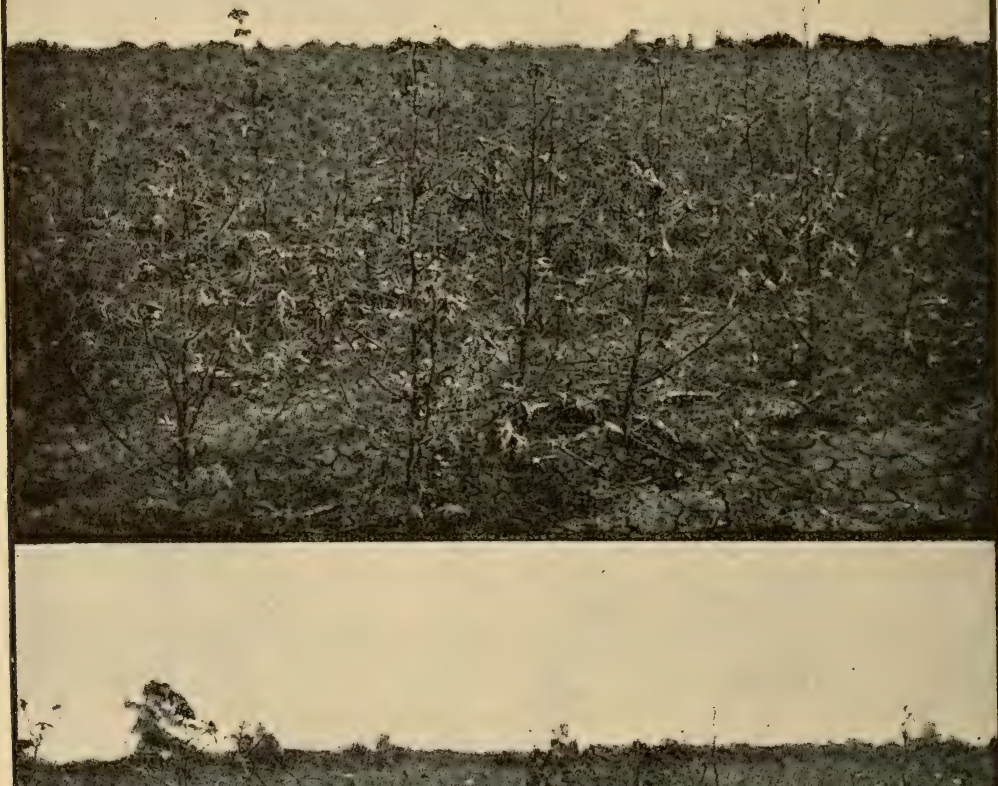

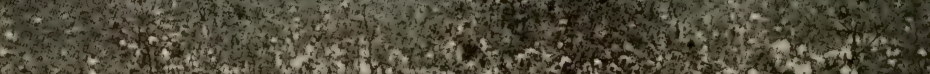

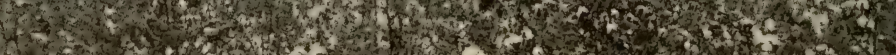

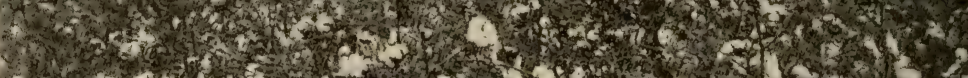

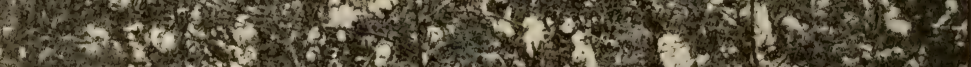

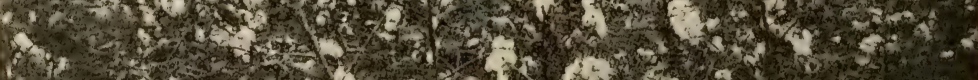
1.t.

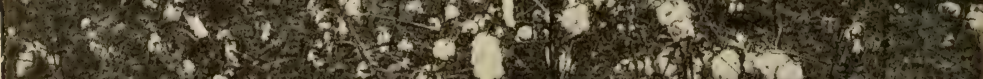

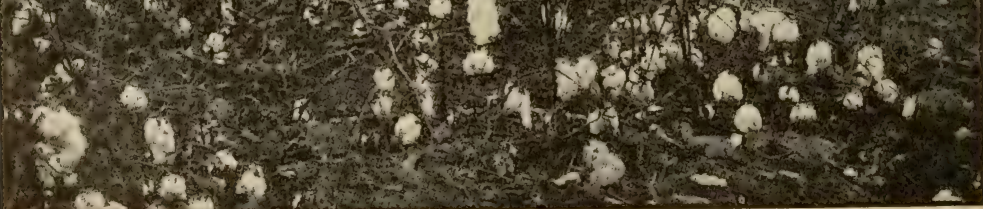

Fig. 45. - Early and Late Cotton in Boll Weevil District 
part of the season, when a few squares fall on account of being punctured by weevils, it is generally agreed that it is profitable to pick these squares up and burn them, since each one contains a young weevil. One weevil destroyed the first of June probably prevents tens of thousands of offspring later in the season. This practice is profitable to each farmer who adopts it, whether his neighbor follows his example or not, because weevils generally stay in the fields where they are hatched until late in the season, when food becomes scarce.

Enemies of the Weevils. - Some farmers are raising turkeys and guinea fowls in large numbers not only for the profit to be derived from the fowls, but for their service in destroying weevils. These birds are said to lessen appreciably the damage done by weevils. Very many species of birds eat weevils, and as a general rule birds should be protected. A little native black ant destroys a great many weevils while they are in the larval stage in the square. These ants are said to be multiplying in the weevil districts, and to be greatly lessening the damage done by weevils in some places. Weevils are also, to some extent, subject to fungous diseases.

This pest is spreading rapidly into the wet districts, but is not moving northwest in 'Texas, where the air is dry and the heat is intense. Hot, dry weather dries out the squares and kills the young. The indications are that this pest will be more destructive as it moves east, on account of abundance of moisture, the shade of the rankgrowing cotton, and the late maturing of the crop. Unless the extra moisture also favors bird, insect, and 
fungous enemies of the weevil, it will be more destructive east of the Mississippi River than it ever was in West Texas.

One especial enemy of insects and friend of man is the toad. He eats an unusual number of cut worms and other pests. It would undoubtedly pay to have pools, or tanks, of water about the farm and garden to encourage toads to multiply. There is little doubt but they would catch a good many boll weevils.

See Appendix for descriptions and means of destroying most insect pests.

\section{QUESTIONS}

What is the estimate of the damage done by the boll weevil in 1907? Are all insects harmful? Name some beneficial insects and tell what great service insects render to plants. IIow can we establish a balance of power among insect enemies? Give an example of such use of insects. Define a real insect. What two classes of insects are there? IIow are the two classes killed? How are cabbage worms killed sometimes? Ilow are corn and pea weevils killed? What cattle diseases are carried by insects? What human diseases are known to be carried by insects and what insects carry the germs in each disease? Show on a map what sections the cotton boll weevil now infests. What food must the weevil have? What goes with them through winter? What do they eat when they first come out in spring? Ilow long does it take for a generation of weevils fully to mature? How many eggs does each female lay and how long will it take one pair to produce a million offspring? Of what advantage is it to cut and burn or graze the cotton field in October as compared with doing the same in December? What methods are chiefly relied on to make a crop where there are weevils? How about fall plowing to help early planting and rapid growth of plants? What kind of cotton should be selected? What disadvantage will the cotton raisers in the more rainy districts have in fighting the weevil? 


\section{CHAPTER XX}

\section{COTTON}

History and Statistics. - The great crop of the Southern States is cotton, and it is one of the great crops of the world. The United States raises something like fourfifths of the world's commercial supply of this staple. The East Indies produce something over 2,000,000 bales of cotton, but it is inferior. Egypt raises a good quantity of fine quality, and China raises a considerable amount, but its quality is inferior. The Chinese often sow their cotton broadcast, and crawl through the patches. and pick out the weeds. Russia raises a few hundred thousand bales in the southern part of her Asiatic possessions. Small patches of cotton may be seen in Japan also, but it seldom grows over a foot in height.

In all tropical countries small quantities of cotton are grown from perennial plants that often grow wild and become almost as large as fruit trees. The tropics were the original home of the cotton plant, but the temperate zones grow it much better.

Our forefathers in America commenced to grow cotton perhaps two hundred and fifty year's ago, but it is not definitely known whether the first seed planted came from Europe and Asia, or from Mexico and South America. It is supposed that seed came from all these countries. 
In round numbers, the United States is now planting $35,000,000$ acres in cotton and producing $13,000,000$ bales weighing 500 pounds each. The crop is worth in all about

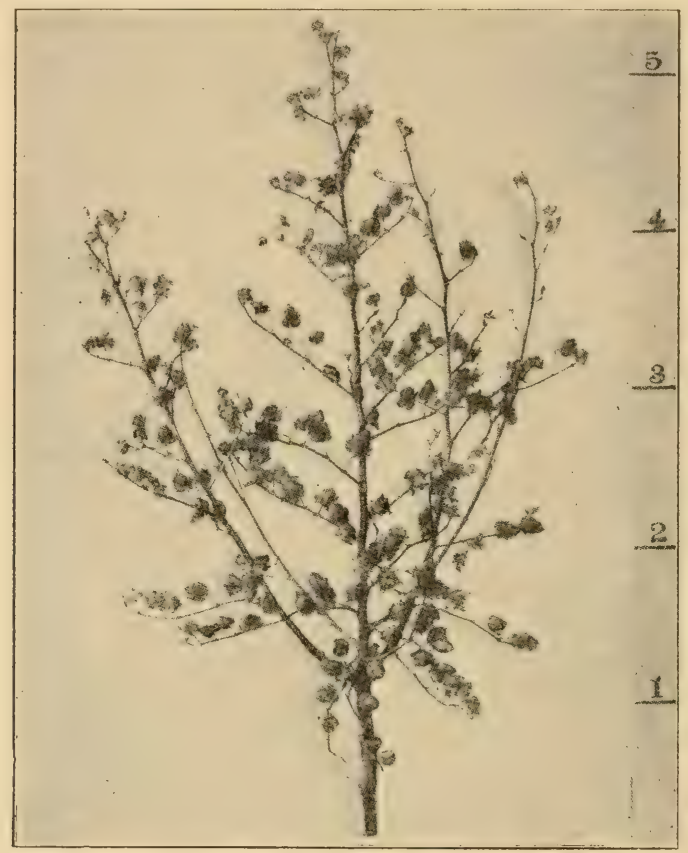

Fig. 46. - Good Type of Cotton Plant

$\$ 700,000,000$, not including the seed, which are worth over $\$ 100,000,000$.

Where Cotton Grows. - Cotton is grown as far north as 37 degrees on our lowlands and 34 degrees on the lands of West Texas having an elevation of three thousand feet. It was at one time believed that cotton needed a 
moist atmosphere, but its successful growth in West Texas proves that it is adapted to a very dry climate also. It is grown in the entire cotton belt on every

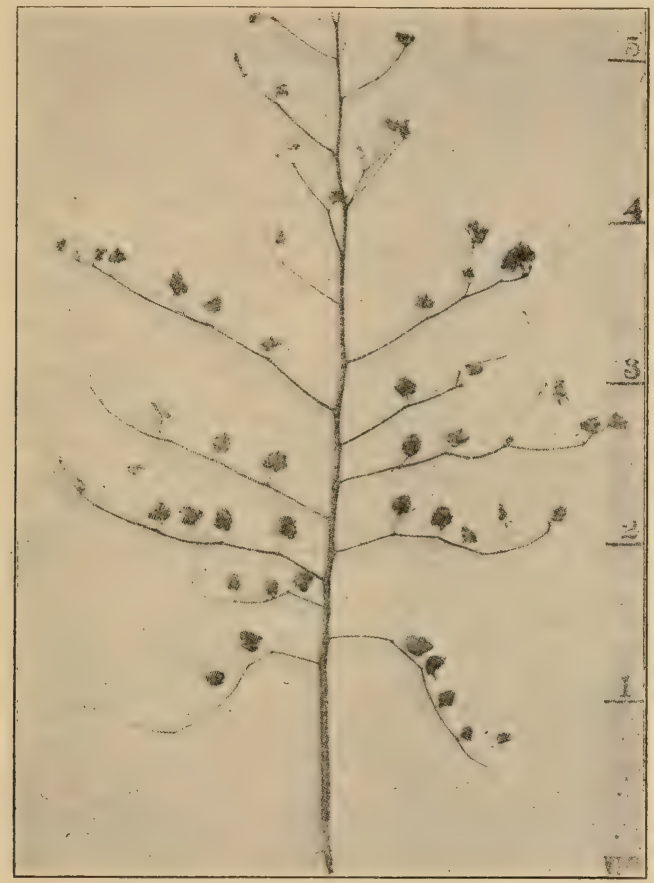

Fig. 47.-- Poor Type of Cotton Plant

kind of land that is even partially well drained and cultivated. There is no other crop that will stand the same abuse in the way of poor preparation, poor culture, poor drainage, weeds, grass, and other unfavorable conditions, and make as good returns. After neglect that would ruin corn or other crops, cotton has often done better 
than when carefully eultivated. Since the coming of the boll weevil, good rapid cultivation has become necessary.

How Planted. - Cotton is generally planted on a ridge, but in the dry areas, and in the sandy lands in the eastern sections, it is sometimes planted on a level. The farmers in each community know when it is safe to plant, and

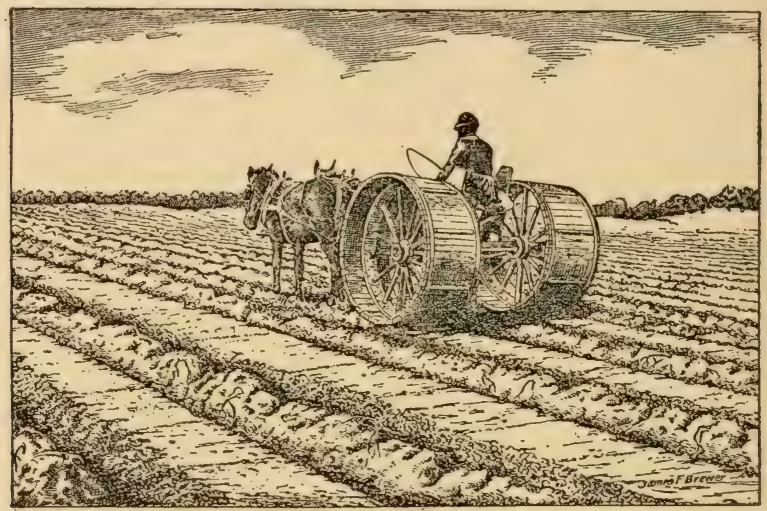

Fig. 48. - Rolling Fresh Cotton Bed to firm the Soil For Planting

whether it is necessary to plant on a ridge. The pupils should learn the details of the cultivation and handling of cotton from their fathers and neighbors. Early planting generally yields better than late planting, but this is not always so. Early planting is very important where there are boll weevils. Late plantings on any rich bottom land are very likely to grow too much stalk and leaf to make a good yield.

Preparation of Land. - In order to be certain of getting a stand of cotton, the land should be prepared some time 
before planting, so that it may settle and become compact. A compact, firm condition enables enough water to be drawn up from the subsoil to sprout the seed even in dry weather. A good plan is to list cotton land in the fall, winter, or early spring, with two furrows of a turn plow. Then, just before planting, the middles should be

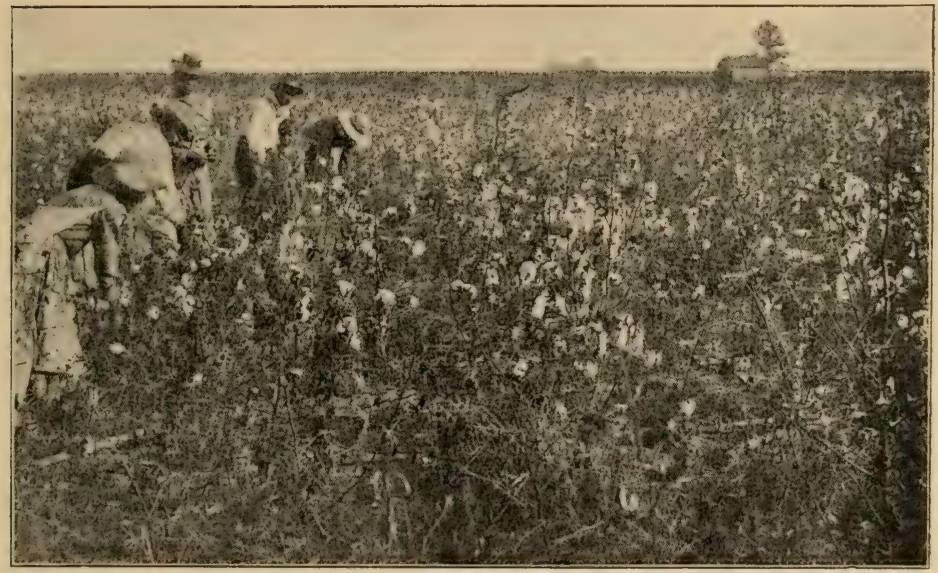

Fig. 49. - Mississippi Cotton Field

broken out. This gives a firm soil to plant in, and a fresh, clean bed for the young plants. Planting time usually marks the beginning of dry weather, when the planter should begin to work to save moisture. The loose, fresh bed will help to save moisture. If prepared just before planting, without previous listing, the land should be rolled, dragged, or harrowed, so as to make it firm. Often when the weather is dry, cotton seed lie in the ground from April to June on account of being 
planted on a loose, fresh bed. Did you ever notice in a very dry season that the cotton or wheat came up well near a turn row where the teams had packed the ground, when it did not come up over the rest of the field?

Depth of Preparation. - As cotton has a long period of growth, it does not need to have the land so thoroughly prepared as some crops do. It is often planted on rough, cloddy land, and if the land is put into good condition during the first working, it will make a good crop. It does not need deep preparation of soil. Some of the best cotton raisers in the country sprinkle the fertilizer in the old cotton or corn middle, and make the bed over an unbroken center. Other successful planter's make beds with a buster, as explained heretofore. These methods are cheap; they allow the work to be pushed along, and make about as good seed beds as the more expensive methods. It is often the case, as explained before, that (clay or bottom land in the rainy belt, when deeply prepared in the fall, winter, or early spring, holds so much water that it cannot be planted early, and when it is planted, remains so cold that the crop does not grow rapidly. Cotton also adapts itself well to different modes of cultivation. Where coco, or nutgrass, is bad in Mississippi and Louisiana, the farmers fight this grass by throwing dirt in the rows with turn plows and covering the grass. When laid by the cotton is often on a riclge two feet high, but it makes just as good a crop apparently as if cultivated on a level.

Different Methods for Different Sections. - It is a great advantage, in many cases, to list the land in the fall or 
winter, with two furrows, as has been explained, and let it remain firm and compact until just before planting time. This will allow the excess of moisture to evaporate, and make the land warm enough for the crop to come up and grow fast. This advice applies especially to land in the eastern part of the cotton belt, where there is almost always too much moisture in the early spring. To secure the best results in the dry parts of the belt, it is imperative that the land be prepared in the fall or early winter, and be kept harrowed and in good tilth right up to planting time in the spring. In fact, where the rainfall is only about twenty inches a year, the land on which crops are planted in rows should never be allowed to get out of tilth. Cultivators or broad sweeps should be run at intervals until corn-gathering or cotton-picking time, and then the same implement should follow the gatherers or pickers in order to save moisture for the next crop.

In the more rainy sections this same thing should be done if crops of any kind are to be planted on the land in fall or early winter, for in the rainy sections of the cotton belt the conditions for fall seeding are about as unfavorable as they are in the semiarid sections. If, however, the land in the humid sections is not to be planted again till the following spring, it needs no such treatment, for it almost always gets too much water before spring.

Professor R. L. Bennet, Cotton Expert of the Department of Agriculture, after studying cotton at the Texas Agricultural College for four years, came to definite conclusions as to the method of securing an early, prolific 
cotton which will make a good crop before the weevils get numerous enough in summer to do serious damage.

He found that certain types of big boll cotton are easy to pick, and make bolls just as early as small boll cotton.

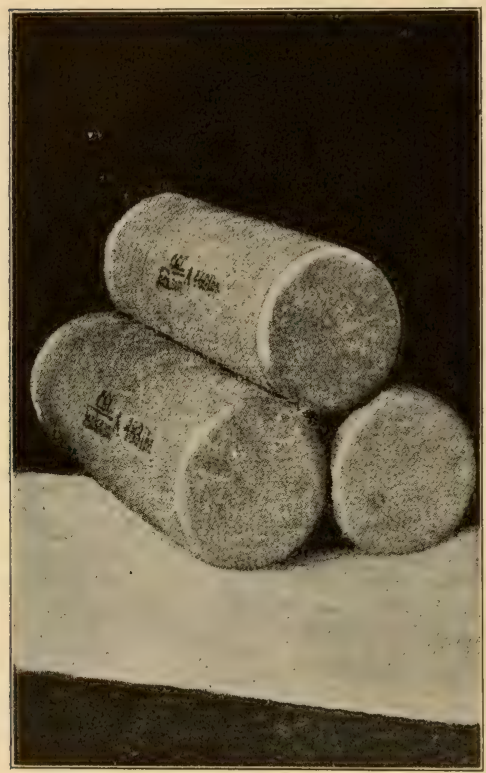

Fig. 50. - Round Cotton Bates
Although the big bolls do not dry and open so quickly as the small bolls, yet they become large enough to be secure from the attack of the weevils just as early in the season as the small bolls do. These types have an additional advantage in that when the cotton opens, it is not so badly blown out by storms.

By selecting certain types of stalks from fields of good kinds of cotton grown in each neighborhood, and growing the seed from the single stalks separately, the farmer can get kinds of cotton far superior to that produced from most seed that are offered for sale at high prices. Usually the seed from a single stalk will yield very true to the parent plant. Efforts to improve the seed grad̦ally by high fertilizing every year have not proved satisfactory. If the right type is selected and this type breeds true, the improvement is 
made all at once. The seed from one stalk can be multiplied fast enough to plant a good-sized field the third year.

Cotton plants have nodes or joints. Short-jointed stalks that grow fast and fruit rapidly should be selected. Mr. Bennett makes the following suggestions :-

1st. The stalks selected should have fruit limbs beginning not higher than the fifth or sixth joint above the lowest, or seed-leaf joint.

2d. The wood limbs, or primary limbs (large branches which themselves put out fruit limbs) should be low, and preferably not over four in number.

3d. Joints on primary and on fruit limbs should be short - from one to three inches in length.

th. Fruit limbs should grow at the successive joints of the main stem and the wood limbs.

5th. All the fruit limbs should continue to grow and fruit until the plant is matured.

6th. The widest leaves should not be over six inches across. Wide leaves keep out the sun, and the weevil thrives in the shade. Figure 46 shows the type of cotton to select. Figure 47 shows the type not to select. After Mr. Bennett gets the right type of seed, he plants early, fertilizes highly, and works the crop rapidly to make it grow and fruit as fast as possible. He believes in picking up the fallen squares in the early part of the season, and in pasturing the fields early in the fall or destroying the stalks, or doing both, as a means of making the weevils less numerous the following year.

Cost of Cultivation. - Cotton is much easier to cultivate in the western part of the belt than in the eastern. In 
the western part, one hoeing or chopping, costing about fifty cents an acre, is required. In the eastern part, from two to three hoeings are required, costing perhaps on an average of $\$ 2.50$ an acre. The cultivators should be run as often in the west to save moisture as they are in the

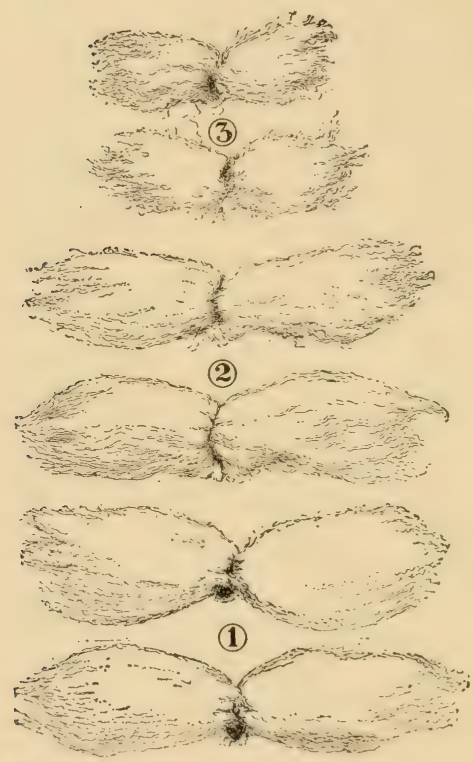

Fig. 51. - Long and Short Staple СоттоN east to kill grass and weeds. Cultivation is always easier and cheaper anywhere if the crop can be worked often and kept from getting foul with weeds.

\section{Thickness of Planting. -} All the experiment stations in the South agree that the yield and earliness of a crop of cotton are increased if the plants are rather thick in the rows - from twelve to twenty-four inches apart when the rows are from three to four feet wide, the widest spaces in each case being on the richest lands.

Length of Staple. - Shortstaple cottons, having a lint about one inch long or less, make up the great bulk of the crop. In some cases, however, on rich bottom lands and highly manurerl uplands, cotton having a staple one and a half inches long or more is raised. These long-staple cottons bring perhaps fifty per cent more than the short-staple cottons. 
The black-seeded sea-island cotton, grown near the coast. and on some islands of South Carolina and Georgia, is the finest cotton grown in the world. It is worth three times as much as short-staple cotton. Short-staple cottons, however, generally yield more and turn out a larger proportion of lint to the seed than the long-staple kinds.

\section{Ginning and Baling. - Cotton} has nearly always been poorly handled. It is often carried to the gin when moist. The gin runs too fast and cuts the lint badly even when the cotton is dry. Each bale carries to Europe or to the domestic mill thirty pounds of bagging and ties that are thrown away, and yet it is poorly wrapped. It is cut and torn in taking numerous large samples from the bales. It lies out in the rain and suffers

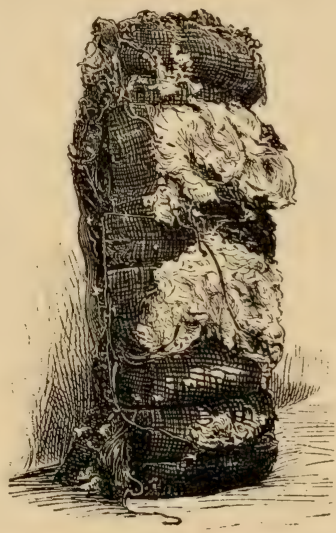

Fifi, 52. - AMERICAX BALE OF COTTON AS IT GETS to Europe

damage. It goes to the compress for repacking, and finally goes to the ship for export so poorly packed that it has to be screw-pressed into the ship at heavy expense. For all these expenses and losses the farmer actually pays in the smaller price he gets for his cotton at home. If all these losses, or nearly all of them, could be avoided, cotton would perhaps bring the farmer a cent a pound more than it does under the present conditions.

Kind of Bale. - If the cotton could be packed densely in a round bale that would save so much sampling and require 
hut a few yards of cheap burlap covering, the saving to the farmer would amount to a great deal. Heretofore this method of baling has been objected to, because the owners of the presses wonld not sell them, and appeared to he seeking to create a monopoly of baling cotton. As som as patents expire and ginners can buy these presses, it would seem to offer a means of effecting great saving to the cotton farmers.

Judging Cotton. - All farmers and farmer boys and wirls should learn how to judge cotton. They should get some samples of known classes and practice judging. While cotton is in the seed, a fairly correct judgment of its quality can be formerl. Pull the seed apart and straighten out the lint, as in Figure 47 , and compare the lengths. You will find the longer staples will make much larger tufts. Then if the cotton is quite free from trash, dirt, and stain, and is gimned carefully, you will know that it should bring a large premium over ordinary kinds. If a farmer sells a steer, he knows whether it is fat; if he sells butter, he knows whether it is of good quality; yet he allows the cotton buyer to be the sole judge of the quality of his cotton.

The Seed. - Cotton seed, until a few years ago, were for the most part wasted. Mississippi has an old law on her statute books prohibiting ginners from throwing seerl into creeks. Seed are now known to be very valuable as a fertilizer and as a feeding stuff. They yield oil that is refined and made into compound lard, butter, and salarl oils; the cake and meal are used for fertilizers and cattle feed; the hulls have proved to be a good rough feed for 
cattle; and the short lint, called linters, got by rumning the seed through the gin before they are liulled, has various uses. A ton of seed yields about 40 gallons of oil, 800 pounds of meal, 800 pounds of hulls, and 40 pounds of linter's. By studying market prices of these products, remembering that the oil mill should have four or five dollars a ton of seed for expenses and profits, one can always form a correct estimate as to what is a fair price for seed.

Large numbers of cattle are fattened on cotton-seed hulls and meal mixed, but the most of the meal is exported to Europe. The oil and linter's are also largely exported.

Feeding Seed and Meal. - People having cattle to feed should not sell seed for less than two-thirds the price of cotton-seed meal. The worth of seed for feed is fully two-thirds that of meal, ton for ton, but somewhat more care may be necessary in order to get the best results from feeding seed whole.

\section{QUESTIONS}

Through what degrees of latitude does cotton flourish in the United States? At what elevation above sea level is it being grown? Is the old idea that cotton needed a moist atmosphere correct? Is cotton a rery hardy crop? Are early or late plantings of cotton most likely to yield good crops? Would you recommend early or late planting where the boll weevil is prevalent? What is likely to happen if cotton is planted late on rich bottom land? Explain how land may be listed in the fall or winter for cotton, so that the berls may be finished just hefore planting time. Give the advantages of this plan. If cotton must be planted on fresh beds, what advantage would it be to roll the beds or drag something heary over them? Why is it that cotton will sometimes come up near a turn row when it does not over the rest of 
the field? Does cotton require as thorough preparation of land as some other crops? Does it need the soil deeply prepared? Will it make a good crop if the bed is made over an unbroken center? In the humid sections, would you plow land to make it hold more water in winter, or would you handle it in a way to make it get rid of some of the water? In the wet districts, about what time in the spring would you commence to work your laud to make it hold its water? Why would you harrow wheat and oats in the semiarid sections while they are growing? Why would it pary to run cultivators through your cotton, kafir corn, and other crops in dry sections until the crops are gathered? Why is not cotton with big bolls as early-opening as smallboll cotton? Why is big-boll cotton to be preferred to small-boll cotton? Describe the kinds of cotton that have proved earliest and that prover to make the best crops where boll weevils are bad. Where is cultivation of cotton cheapest, in the dry or wet section? Will cotton make more growing close together or far apart in the rows? Will cotton make earlier if grown close in the drill? Will it make a larger yield? What is the finest cotton known? Tell some of the ways in which cotton is badly handled. If handled in a better way, would it bring the farmer a better price? Why should all farmers know how to class their cotton? How can you tell something of the value of your cotton before it is gimned? What are some of the uses of cottonseed oil? What products do the oil mills get from a ton of cotton seed? Can you tell from these products about what the farmer ought to get for his seed? What are the relative values of cotton seed and cotton-seed meal for feeding cattle?

Experiment. - Get a cotton buyer to give you samples of middling cotton, low middling, good middling, and middling fair, with the differences in value of them. Practice sampling and judging for yourself. Do this at school. 


\section{CHAPTER XXI}

\section{CORN}

Indian Corn, so called because it was first found among the American Indians, is the greatest single crop grown in any one country on earth. The annual value of the crop grown in the United States is about one and a quarter billion dollar's. Texas stands about fifth or sixth among the states in corn production. Something like a hundred different commercial products are manufacturer from the corn plant, such as oil, rubber substitutes, starch, sirup, alcohol, packing for battleships (the pith of the stalk is used for this purpose), Missouri cob pipes, and many other things.

Origin. - This giant grass had its origin in tropical America, but like many other plants of like origin, it makes its best growth toward the northern limit of the area of its production. It grows all the way from Camada to Cape Horn, and has spread to the warm parts of Europe and the Far East, including Australia and Australasia.

Kinds of Corn. - We lave dent, flint, sweet, and pop corms. The dent corn is of especial interest in most of the corn belt as a field crop. Flint corn matures quickly, and is grown in the extreme northern part of the belt. It does not usually make large yields. Dent corn is 
shriveled at the large end of the grain. Of the yellow and white corns of the dent variety, the white kinds have usually yielded better in all the southern half of the corn belt, and they are somewhat better for making bread.

Soil and Fertilizers. - Corn is grown on all kinds of land, but it does not flourish with as poor soil, drainage, culture, ete., as cotton does. Corn does its very best on rich, well-drained bottom lands, that have plenty of humus. On thin uplands corn needs not only better fertilizing than cotton, but also a somewhat larger proportion of nitrogen in the fertilizer. Therefore all fertilizer mixtures for corn should have a little less acid phosphate and a little more cotton-seed neal, nitrate of soda, or cotton seed than those which are intended for cotton.

Preparation of Land. - It has commonly been supposed that corn land needs deeper preparation than cotton land, but evidence from Southern experiment stations does not indicate this. The land needs thorough, but not necessarily deep, preparation - perhaps five inches deep. Corn can be planted earlier than cotton - perhaps two or three weeks.

Selecting Seed. - The same general principles for selecting seed as have been recommended for cotton apply to corn; but as corn is very likely to cross, the desiral)le shoots had better be covered and pollinated artificially. For sections having plenty of rain a larger stalk and later-maturing type would make a better yield. Farther west, where moisture is less abundant, a smaller stalk and quicker maturity would be better. It matter's little whether corn for seed tends to bear one ear or more 
than one. Corn yields best when planted so thick as to average about one ear to each stalk. 'Testing out the best selections from individual stalks in one's own neighborhood, or on one's own farm, is better than orlering from some distant state seed corn which is said to have a fine pedigree and high yielding record. Farmers should order at most only small quantities of seed from a distance, and carefully test them out for adaptability to their own localities and conditions. Corn generally adapts itself to a locality, and

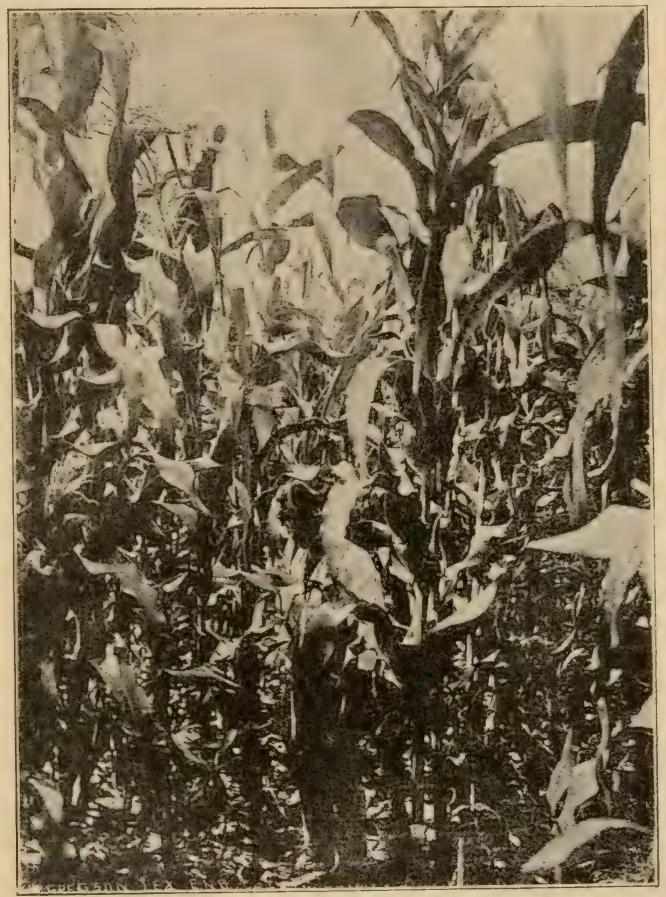

Fic. 53.-Cory and Peas yields better than the same kind brought from a distance.

Yields and Expenses. - In much of the South the average corn yield is low - being from ten to twelve bushels to the acre. In some of the Northern States the average yield runs up to nearly forty bushels. In both North and 
South from seventy-five to eighty bushels to the acre are not uncommon. Suppose you find out how much work is done on each acre of corn on your father's farm, including preparation of land, planting, plowing, hoeing, gathering the crop, etc. ; then by counting a day's work of a man at a dollar and the work of a horse or mule at fifty cents, and estimating the value of land rent, seed, and fertilizer, find out what is the expense of raising an acre of cor'n. Then estimate the yield and give it the value corn has in the neighborhood, and see how much is made or lost. You might do the same with cotton and other crops.

Saving Fodder. - It used to be a very common practice in the South to strip) the leaves from the cor'n when it got nearly dry, and to cure these for fodder. This makes a fine feed, but a man can strip) so little of it in a day that people are abandoning this plan of providing rough feed. The Texas Experiment Station many year's ago tested the plan of saving the forkler by cutting off the tops of the corm. In proportion to the amount of feed saved, this plan proved much cheaper than stripping the blades from the stalks. The plan generally followed in the main part of the corn belt is to cut down the whole stalks and put them up in shocks until they are cured, and then to shuck, or husk out, the ears of corn. What is left is called stover, and is fed to cattle through the winter. 'This stover is often torn up into fine pieces in a shredding machine, and the product is called shredded corn stover. Shredding is expensive, and the feed is not greatly improved by the process, for the shredded stover is very hard to keep. In the South, corn stover is more subject to injury than in 
the North, because the stalks of the corn are larger and hold more moisture. This process is not growing in popularity in the South. Even in the corn states perhaps not one farmer in a hundred shreds his stalks. It is probably better to break the corn from the stalk in the old way, and then allow the stock to graze on the fields. One Northwestern experiment station has found this the more profitable plan.

Another chapter will tell how to keep weevils from injuring corn.

\section{QUESTIONS}

Where was Indian corn first found? How does this crop compare in importance with other crops of the world? Name some of the products manufactured from corn. Where did corn originate, and where does it grow best? What different kinds of corn have we? What is the best kind of corn in the South? Does corn grow well on all sorts of land? Does soil for corn need very deep preparation? Are different varieties of corn likely to cross? What could be done to prevent crossing? For sections having plenty of rain, would you select late corn or early corn? Would it be safe to order a large quantity of seed corn from a great distance? How large a yield of corn can be got under good conditions? IIow could you estimate the profits or losses on an acre of corn? Is pulling fodder a profitable practice? What is corn stover? What is shredded stover? Is it profitable to save and shred corn stover in the South?

Experiment. - If you live in a section where corn is grown for market, get samples of market grades of corn from a buyer and learn to judge these grades and value them. This is a suitable school exercise. 


\section{CHAPTER XXII}

\section{WHEAT AND OATS}

Wheat is one of the oldest grain crops. It is particularly adlapted to northern latitudes and elevated regions. It is a cold-weather plant, though it may grow well in sections where the weather gets very warm about the time it is ripening. Wheat thrives where the weather is too

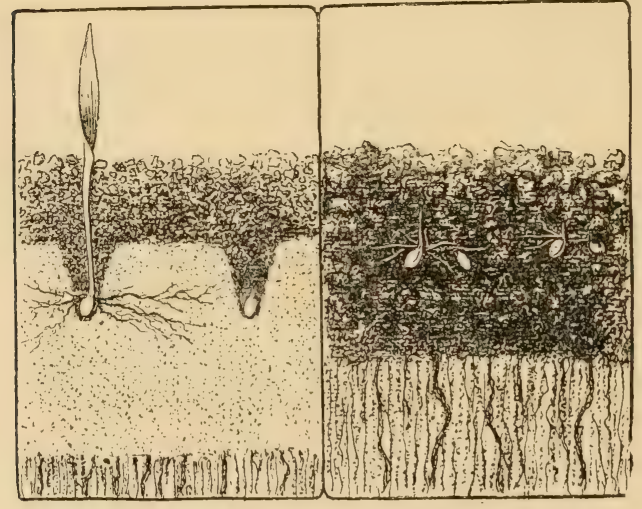

Fig. 54. - Wheat planted in Loose SoIl aNd in SOIL COMPACTED cool or the rainfall is too little for corn. It also does well over most of the corn belt of the United States.

It is hardly advisable to plant wheat in South Texas or in any part of the Gulf States east of 'Texas unless it be on the highest lands of Alabama. It is liable to rust, and the crops will usually not pay.

Wheat has a decided preference for clay soils. It does not do well in a deep, loose seed bed. Preparatory plow- 
ing may be shallow, and the soil should be firm and compact. You perhaps remember the story of the English peasint farmer whose wheat had been run over, and trampled upon by the hounds of a nobleman who was hunting on the peasant's farm. The peasant demanded and received a certain sum of money as damages, but afterwarls returned the money, because he foumd the

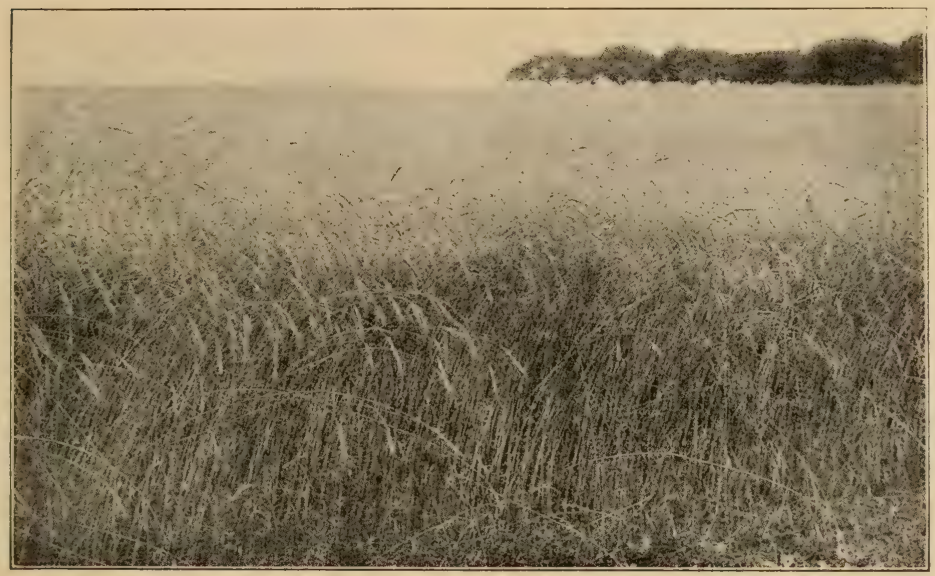

Fig. 55. - Wheat Field on the Plains

wheat most trampled by the hounds was the best. Pasturing wheat moderately in fall and early winter is generally found beneficial, if done when the land is not too wet. Pasturing is also good for oats, barley, and rye.

Fertilizers. - IVheat grown on the same grade of land as corn needs a larger proportion of nitrogen in its fertilizers than does corn, because it grows in spring and ripens in early summer before nitrogen compounds have begun to form rapidly. But since wheat is mostly grown far 
enough north and west to insure soil having a larger supply of nitrogen than the thin Southern corn lands have, a moderate proportion of nitrogen is likely to be sufficient.

Wheat and Cotton. - I' There cotton and wheat grow in the same section, a crop of wheat may very suitably follow a crop of cotton. If the cotton is well worked right up to picking time, wheat may be sown after one of the pickings and covered with a walking cultivator. The cotton stalks may be eut and dragged off after the picking is finished. This dragging will serve as a harrowing and will help the wheat crop. Often the cotton can all be picked in time to sow wheat. In this case a good chopping up) with a disk harrow will put the land in fine shape for the wheat drill. Where wheat is to follow corn, kafir, milo, or sorghum, the same treatment of land is recommended; at suitable intervals the land should be worked with cultivators between the rows right up to wheat-seeding time. This should be done as a means of saving moisture.

Wheat after Small Grain. - If wheat is to follow smallgrain crops, the stubble of the latter should be disked and plowed and re-disked from time to time till seeding time again, in order to save moisture for the new crop in the fall. In the dry sections of the West this would be safer than to risk a pea crop between the two grain crops, because a large pea crop pumps out an immense quantity of water. If the pea crop is tried, it should be planted in rows and kept well cultivated till it is cut. The land should then be well disked and seeded. If the pea hay is 
particularly desirable, it might pay to grow it, even if it caused a failure in the wheat crop.

In the southern part of its territory wheat is nearly always seeded in the fall. Farther west, where the winters and springs are dry, wheat fields should be harrowed from time to time until as late as April, or as long as it can be done without hurting the plants. This treatment saves moisture, and the moisture helps to prepare food in the soil for the crop. H. W. Campbell, in his dry-farming operations, drills his wheat in twenty-inch rows and cultivates between the rows with a cultivator that works several rows at a time.

The Green Bug. - Proper working of the land to save plenty of moisture for starting the wheat off vigorously, and then pasturing in the fall, seems to be the best treatment against the green bug that is sometimes so destructive. This insect starts on the sickly yellow plants on poor spots of land which have not been properly prepared. The cattle and sheep while grazing eat up the bugs, and when the young leaves grow out, dark and green, they are not so well suited to the bugs' tiste as yellow, unthrifty older leaves.

A Barrel of Flour. - It requires about 258 pounds of wheat, or 4.3 bushels, to make a barrel of flour. This. amount of wheat should yield, according to Dr. H. WV. Wiley, Chemist of the United States Department of Agriculture, the following products :-

Patent Flour .

Bakers' Flour .

Low-grade Flour

Total Flour .
149.37 lbs.

$29.13 \mathrm{lbs}$.

$17.50 \mathrm{lbs}$.

$196.00 \mathrm{lbs}$. or one barrel 
Wheat Bran

Shorts

Screenings

Waste or loss .

Total .
$45.56 \mathrm{lbs}$.

$9.80 \mathrm{lbs}$.

4.99 lbs.

2.35 lbs.

258 lbs. or 4.3 bushels

By studying the market values of flour and the byproducts, bran, shorts, etc., farmers can tell pretty well what price to demand of the miller's for wheat, or what amount of wheat to offer in exchange for flom, feed, etc.

Oats can be grown profitably farther south than wheat, provided Texas rerl, rust-proof varieties, or other kinds not so subject to rust, are chosen. The oat is a profitable (rop) clear to the seacoast in all the Gulf States. Under a system of fertilizing and rotation it is a good crop on the smail farms throughout the large area of sandy-loam lands of the (rulf and South Atlantic States. On the lime and clay lands not artificially drained, the soil is often ton wet in winter and early spring for oats to do well. In the South oats do much better when sown in the fall, although fair crops are got from sowings made in February.

Method of Planting. - To make sure that the fall sowings will not be killed by frosts, the seed are often drilled on freshly plowed land, the drill rumning northeast and southwest and sinking well down in the plowed ground and leaving little ridges between the drill row. These ridges serve as wind-breaks, and prevent the little plants from being killed in the winter.

Fertilizers. - Oats need decidedly more nitrogen in their fertilizer than cotton or corn needs, on account of maturing 
before the weather gets warm enough to form nitrates in the soil rapidly. Two or three hundred pounds of the mixture recommended for old lands, drilled with the seed, and a top) dressing of a hundred pounds of nitrate of soda, harrowed in during March or April, can be counted on to make a good crop.

Rotation. - Peas should almost always be grown on the land after the oats are harvested, not only on account of their value for hay, but because of their excellent effects on the lank. In one experiment on thin, sandy land at the Alabama Experiment Station, previous erops of cowpeas and relret beans - part of each having been eut off for hiay and part turned under, vine and all-made increases of the oat yield of about twenty-five bushels to the acre over similar pieces of land, one of which had grown sorghum and the other crab grass and hog weeds. Oats, when not followed by a (rop of peas, are very exhaustive to the land; but when followed by peas, the land is greatly improved.

Oats and Vetch. - Iairy vetch seed are often mixed with oats, and the two thrive together and make a dense growth. The retch is a legume, and improves the land. Sometimes the vetch climbs up on the oat stalks and in stormy weather pulls them down, causing considerable loss. From the seed which it sheds on the ground the vetch comes up rolunteer in the fall. It makes a good winter and early spring pasture, and a fine hay plant when grown alone or with oats.

Winter Growth. - A crol' of oats, or oats mixecl with veteh, followerl by peas, makes a fine preparation of the 
land for cotton or any other erop the next spring. Besides, the oat and vetch seed which are lost at harvest time come up in the fall and clothe the land in green during the winter. This is of great advantage in sections where the winter rains are heavy. 'The green crop talies

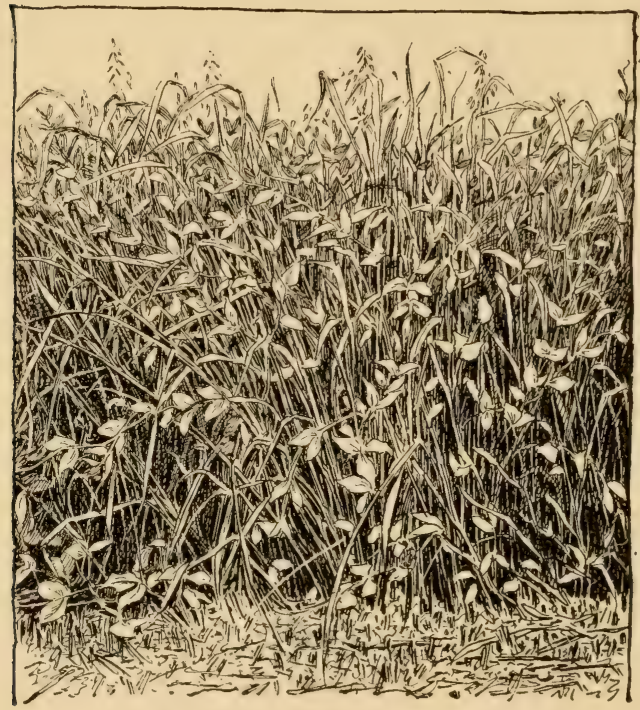

Fig. 56. - OAts and Vetch up the soluble plant food and prevents it from being washed away. It also helps to evaporate some of the excess of water. Then when the land is plowed in spring, the plant food is given to the regular crop as the green stuff rots. Where fall oats or fall oats and vetch are grown in rotation with corn and cotton, each field has a green cover crop two years out of three, and this is of itself of great value.

The same general facts that have been given about wheat and oats will apply to barley and rye. No attempt has been made to give details about any of these crops. Don't fail to learn more from your fathers and friends about these crops, and about the tools, implements, and 
machines that are used for working and handling them.

\section{QUESTIONS}

What kind of country and climate suits wheat? Will corn do well in all wheat countries? Which will grow farther south, wheat or corn? Would you plant wheat in South Texas or Mississippi? How should wheat land be plowed? Does it hurt wheat to graze it in the fall? Does wheat need as much nitrogen as corn? Do wheat and cotton do well in the same section? How could you sow wheat in cotton fields? In dry sections, how late would you work your crops? Why would you harrow growing wheat in diy regions? If you intended to follow small grain with wheat, in dry regions, would you plant a pea crop after the small-grain crop? What time of the year is wheat sown in the Sonth? What treatment is suggested for the green bug? IIow much wheat does it take to make a barrel of flour? What other things are got besides the flour? Which will grow profitably farther south, oats or wheat? Iow are oats planted to keep them from winterkilling? Which needs the more nitrogen in the fertilizer, oats or corn? Why is this so? What should be done with the oat land after the oats are cut? Give an example of an increased yield of oats on account of leguminous crops. What crol is often grown with oats? Is the oat crop alone exhatistive to the land? Is the oat crop, followed by peas, exhaustive to the land? Of what advantage is a green crop to land in winter? In humid sections, what effect will the green crop have on the moisture? Would a winter crop be of advantage in dry sections?

Experiment. - Study market grades of wheat in the way suggested for corn and cotton. Try growing some wheat or oats in drills on the farm at home and cultivating between the rows. See if you can make a much larger crop and at the same time not plant over half as much seed. Try nitrate of soda, one hundred pounds per acre, as a top dressing in March or April on a small piece of oats or wheat. 


\section{CHAPTER XXIII}

\section{RICE}

Use and Varieties. - Rice is used as an article of food by a great many of the earth's inhabitants. An enormous amount of rice is grown and eaten by the hordes of people in China, India, Japan, and Australasia. Rice is of many colors, including black, red, and white. There are very many varieties adapted to different conditions, from the salty marsh lands near the sea, up to the mountain summits many thousand feet high. Some kinds assume a dwarf habit, and come to maturity when two months old in the dry, hot season. Other kinds are planted at the beginning of the flood season in the great river bottoms of the Far East, and grow and grow as the flood rises, till they reach a height of twenty feet, and then mature floating on the water, so that the harvesting has to be done in boats.

Oriental Methods. - The people of Oriental countries almost always plant their rice thick in seed beds. When it is six weeks or two months old, they set it out in the land where it is to grow, planting about 75,000 plants to the acre. The land is first plowed and raked when muddy, and all the grass is killed. The rice plants are set in this mul, and rain water or irrigation water is made to cover the land and keep down weeds and grass. In China, 
Japan, and India, transplanting is necessary in order to give the people time to raise a crop of barley or vegetables, which they must grow in winter and spring, and yet have their rice early enough. In the Philippines, Java, and Borneo, this plan is of advantage, because there are so

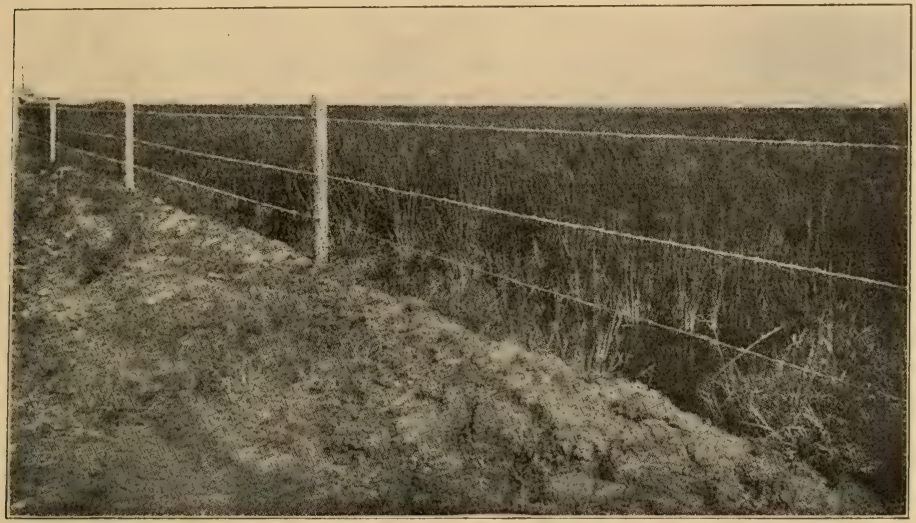

Fig. 57.-Rice Field in Louisiana

many coarse grasses, like Johnson grass or worse kinds, that would grow faster than the young rice and choke it out. By cleaning the land and setting plants when a foot high and putting on water, the fields can be kept clean, and good crops can be made.

In the Philippines, men, women, and children - perhaps a hundred or more - meet at a field that is to be set in rice. They have a string band, and as the band plays, they set rice in the mud, keeping time to the music, as if dancing.

Southern Methods. - Louisiana and Texas are growing the bulk of the rice crop of the United States now; South Carolina, Georgia, and Arkansas grow a comparatively 
small amount. The level, stiff clay prairies of Texas, Louisiana, and Arkansas are ideal for rice. They are level enough for large areas to be surrounded by a small dike, or levee, so as to hold the water over the land at an even depth. Water plays an important part in the cultivation of rice. Enough water is tumed on the field to drown the

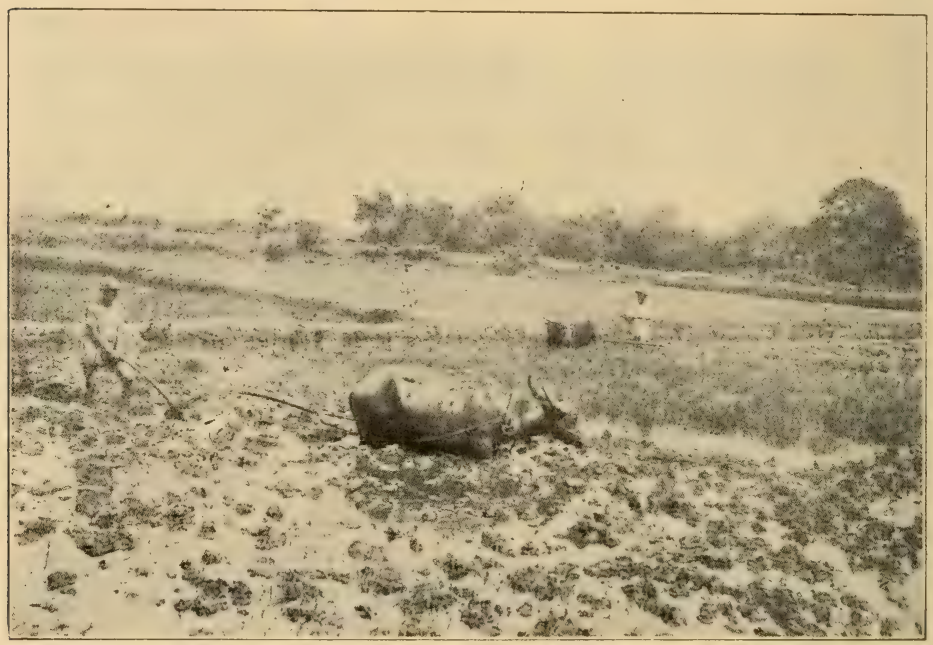

Fig. 58. - Filipinoes Plowing in MUD PREPARING LAND FOR RICE

weeds and grasses, but not enough to cover completely the rice at any place in the field. The numerous streams and bayous in such a flat country afford an abundant supply of water for the rice. Then pumping from a deep well in which the water comes up to or near the surface will supply a good-sized plantation. Hundreds of these wells are in use.

As this land holds water like a jug, no excessive amounts 
have to be supplied. When water is drawn off into the drains about the time the crop is ripening, the land readily dries and gets hard, so that harvesting machinery can work on it as easily as on a wheat field.

Rice does not need rich land in order to produce a good crop, but bigger yields are made on good land.

Preparing and Planting. - The land is plowed and harrowed when moderately moist, as for other crops. The seed are put in with a drill, as wheat and oats are planted. Water is not turned on till the rice is six inches high. Then lines are rum with a leveling instrument, so as to inclose the most land possible that does not vary in level more than six inches, and these level lines are followed by road graders or other implements to make the levees or dikes, which are seldom more than eight inches high. The land is plowed to a depth of about three inches only. This depth of plowing makes just as good a crop as deeper plowing, and it leaves the land harder for the harvesting machinery to run over. Sometimes it is necessary to go over the rice fields and pull out large weeds. In South Carolina and Georgia rice is often planted in wide drills and cultivated somewhat like corn.

Red Rice. - A prolific, early kind of rice, having red grains or red streaks on the grains, has become a sort of weed in the rice fields. The seed ripen early, and some fall on the land and come up with the next crop. In this way the variety multiplies so rapidly that the market value of the whole crop is lessened, for in our markets there is no sale for rice with red grains. In the Orient, however, red rice is esteemed just as highly as white; and the black, 
glutinous rice is thought to be the best of all. To get rid of the red rice seed, the fields are usually allowed to lie idle a year or two, and then fresh, clean seed are again planted.

Yields and Profits. - Rice in Louisiana and Texas averages about 1500 to 1600 pounds of rough, or uncleaned, rice to the acre. This is about 35 bushels, or a little over twice the average wheat yield in the United States. Some plantations frequently produce twice this amount. The Hawaiian Islands average 8000 pounds of rough rice to the acre in two erops grown in one season, or something over 175 bushels to the acre in one year.

As rough rice sells in the United States for about the same price as wheat, it would seem to be a much more profitable crop. It costs more, however, to grow rice. Water must be pumped or paid for, if furnished by a canal company, dikes must be made and kept up, and the water must be distributed regularly to the fields. Then some weeding is required. Otherwise the methods of culture and harvesting of the two crops are much the same. Rice allows a longer period of time for harvesting than wheat, so that one man can save much more. By planting kinds of rice which ripen early and kinds which ripen late, the farmer may prolong his harvest season for nearly three months.

Fertilization. - Rice is not extensively fertilized in this country, but in the old world it is fertilized in the same way as other crops. Some very favorable results have been reached by fertilizing in this country. Certainly pea crops would give good results if planted during the years the land is idle for the purpose of ridding it of red rice. 
Most planter's, however, use their entire energies and resources in growing a big rice crop on other land, leaving themselves no time or means to grow and save a pea crop).

Time of Planting. - Rice may be planted from April to June. Any rice field that can be well drained in winter may be sown in the fall to hairy vetch or bur clover. These crops will mature a good yield of green manure by the last of April. If the land is well chopped up with disks at this time, the rice may be drilled any time in May or June, without other preparation. Some acid phosphate may be used to advantage when the restorative crop is sowed in the fall. Rice yields could no doubt be much increased in this way; and but for the red rice, big crops could be grown every year.

Bur clover will mature seed by the 30th of April in the Louisiana and Texas rice belt, and these seed might stand the flooding and still come up volunteer in the fall, as they do on dry land.

Manufactured Products. - A sack or barrel of rough rice weighing 162 pounds contains approximately the following products:-

Clean rice . 100.00 lbs.

Iulls (generally burned for power) . $\quad 32.10 \mathrm{lbs}$.

Rice bran .

$20.20 \mathrm{lbs}$.

Rice polish

Loss .

Total

Some 60 pounds of the 100 pounds of the clean rice should be best head rice, 30 pounds No. 2 (somewhat 
broken), and 10 pounds badly broken, called brewers' rice.

With the help of these figures and the market value of rice, bran, and polish, farmers ean draw a fair conclusion as to the market value of a sack of rice. Of course, the better the quality of the rough rice, the more cleaned and head rice there will be, and hence the higher the value it will have.

\section{QUESTIONS}

Is rice a very important crop in the world? Where is it grown largely? What different kinds of rice are grown? How do Oriental people plant rice? Why do they plant it this way? What states grow most of the rice in the United States? What advantages do these states have in rice-growing? What is water mostly needed for in growing rice? Why do rice growers not plow land deep? How do the rice planters keep the water covering the ground? What is red rice? What do the planters do to get rid of red rice? IIow much rice is made on an acre in Texas and Louisiana? How alhout the profits of rice as compared with wheat? How late may rice be sown? What plant could be grown on the land to enrich it in winter? Tell what products can be got from a sack of rice.

Experiment. - See if you can arrange to grow on the farm at lome a little piece of rice, planting by the Japanese method. Try some bur clover on a piece of rice land and see how much increase the rice makes next year. 


\section{CHAP'TER XXIV}

\section{SUGAR CANE}

Sugar cane is grown in all of the Gulf and South Atlantic States for sirup-making, and in parts of Louisiana and Texas for sugar-making. About 300,000 tons of sugar are made annually in these two states. This is one of the oldest industries in the United States, having arisen to commercial importance over a hundred year's ago, when people were picking the seed out of cotton with their fingers.

Cane in Tropics. - Sugar cane is a tropical crop, and still does best in the tropics. As it takes twelve months to produce seed and ripen, cane never gets fully ripe in any country that has frost. In two or three tropical countries, where conditions are very good, sugar cane grows for

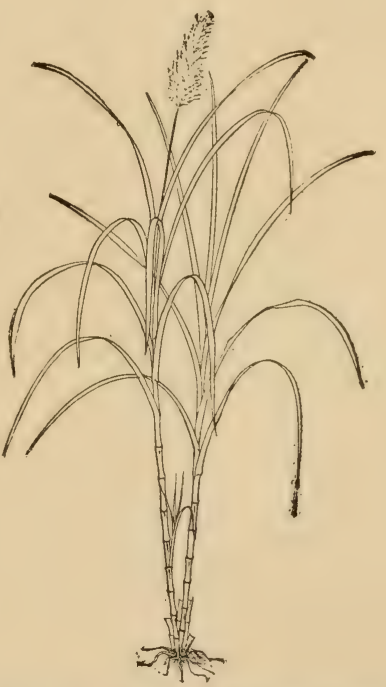

Fig. 5̃9. - Seeded Sugar Cane seventeen or eighteen months before ripening. In most parts of the tropics it ripens and seeds in the dry season when just a year old. People in the tropics do not usually 
plant the seed. They plant a few joints of the tops of the cane. When cane is really ripe, the eyes of the top joints germinate and grow much better than the eyes on the older parts of the stalk.

Saving Seed. - As the top joints of our cane are not mature enough to grow well, we plant the whole stalk. It is much better to dig up the stalks that are to be used for seed, as the roots contain many of the best eyes, or buds. The seed cane is cut or dug about the first frost and piled in long piles and covered with dirt. It keeps better if banked when well wet by rain. It is planted in deep furrows in early spring, sometimes in the fall, a continuous line of cane being put down so that the top of one stalk joins the root of another. In the sugar belt, where cane is cut at the ground, sometimes as many as three continuous lines of cane are put in the furrow.

Fertilizer for cane should contain a larger proportion of nitrogen than fertilizer for cotton. Cane grows large, and needs rich soil. In the IIawaiian Islands, where the largest yields in the world are made, as much as two tons to the acre of high-grade fertilizer are used, and the land is given over 100 inches of water, pumped sometimes to a perpendicular height of 600 feet.

In the United States cane needs a well-drained soil, because poorly drained land is too cold for it. In the tropies it may stand with its roots under water for weeks without being seriously harmed. It needs plenty of rain or irrigation.

Cultivation and Yields. - Cane is not difficult to cultivate. It has existed for ages almost as a wild plant in the 
tropics, where, by doing battle for mastery of the soil with other giants of the land, it grew strong and hardy. After it gets a good start, it is kept clean mostly with turu plows and disks, that heap dirt up to the stalks, and cover the weeds and grass. This is kept up until the cane has. grown tall enough and thick enough, by suckering, to shade the ground and keep down other growth. In the United States, cane when mature yields from 15 to 40 tons to the acre; in the tropies, the yields are usually much larger. In Java, the average yield is 40 tons, and in the dry parts of Hawaii, under irrigation, the average is 60 tons, and on some plantations the yield reaches as high as 120 tons.

Rattoon Crops. - Cane will come up every year from the stubble of the year before, but as the crops get smaller and smaller, it does not often pay to grow more than one or two of these "rattoon" crops. Cane should be cut low, and then the stubble should be cut off with sharp hoes under the surface of the ground. Otherwise, germs will get into the roots and injure the buds that make the stubble, or rattoon crop.

In the United States cane never gets very sweet until frost scorches the leaves and checks the growth. At this season the sirup makers and the sugar makers begin to harvest the crop and manufacture sugar and sirup.

Best Land for Sirup. - The light sandy loam lands produce decidedly the best-flavored and the best-colored table sirup. The pine lands of the Southern States, when fertilized, produce from 300 to 600 gallons of sirup to the acre. This sirup is of such excellent quality that it readily sells 
for 50 cents a gallon. These highly profitable results are reached in spite of the fact that the small horse-power mills which are usually employed for crushing do not often get over two-thirds of the juice that the regular sugarplantation mills would get from the same cane.

Making Sirup. - The apparatus for boiling the juice to sirup consists of a kettle or evaporating pan set on a

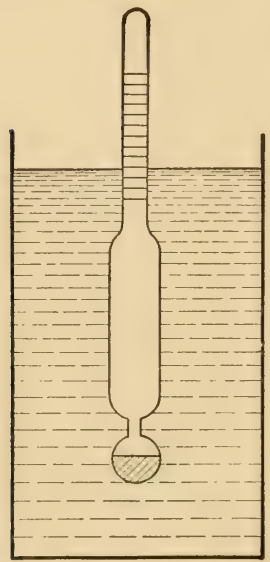

Fig. 60.- WAY TO USE

A SACCHARIMETER rock or brick furnace. It has been decided by the United States Department of Agriculture that no chemical whatever is needed to make first-class sirup from sugar-cane juices. Careful straining of the juice and skimming while it is cooking, and then boiling to a uniform density, is all that is necessary.

Every sirup maker should have a saccharimeter, a little floating instrument that will measure the weight of the sirup. 'The sirup should be boiled down to about 75 degrees, Brix saccharimeter. That is, it should still contain about twenty-five per cent of water. If it is sealed while hot in well-scalded jugs, bottles, or cans, it will keep fresh for years. If the sirup is made rather thin, so that the sugar will all, or nearly all, be held in solution, the quality will be much better. If the sirup is to be kept in barrels, it must be boiled thicker; when this is done, much of its sugar crystallizes and settles in the bottom of the barrels. Sirup not sealed in sterilized vessels will 
ferment when hot weather comes. If barreled sirup is kept in cold storage, it will not grow the germs that cause fermentation, and will keep well.

Making Sugar.-For making sugar, the juices of the cane used to be boiled to a thick sirup over a direct fire, and the sugar allowed to crystallize out. The molasses was then sold as open-kettle or sugar-house molasses. This plan is occasionally followed yet. But the greatest forward step in modern scientific sugar-making was the discovery that, if cane juices can be boiled at a low temperature, more sugar can be made. That

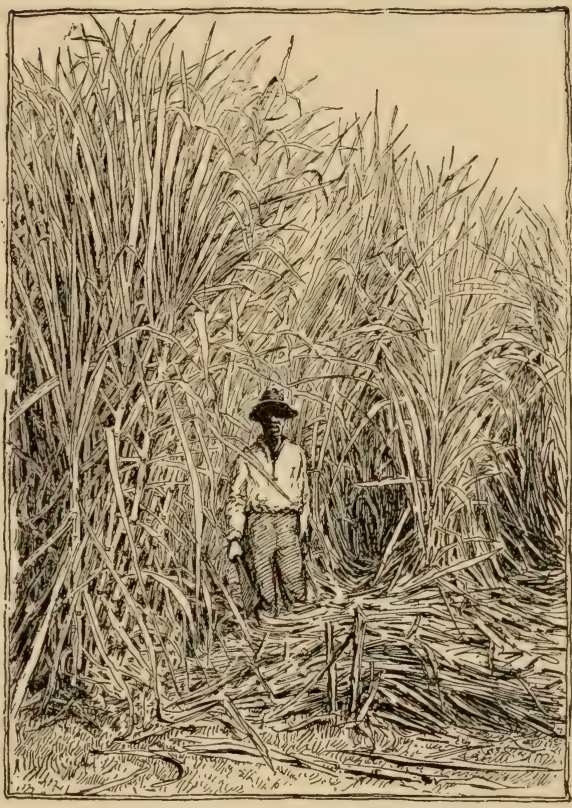

Fig. 61. - Cutting Sugar Cane, Louisiana is, if the juices are cooked over a fire, the high temperature used will invert a large amount of the sugar, or put it in such a condition that it will not crystallize. When the juices, or thin sirups, are put in a large, air-tight vessel and the air pumped out, the sirups will boil at a very low temperature, and less sugar will be inverted. The use of the vacuum-pan gives 
large quantities of sugar and little molasses. The old method gave less sugar and more molasses.

Products from a Ton of Cane. - A ton of Louisiana or Texas cane, worked in a good factory and refinery, will make about 140 pounds of sugar and some two or three gallons of low-grade molasses, called "black strap," which is used for feeding stock. Some centrifugal molasses of hetter grade will also be ohtained. A ton of tropical cane will make from 200 to 250 pounds of sugar and probably three gallons of low-grade molasses.

Impure Juices. - If cane is very green, it contains much invert sugar, or non-crystallizable sugar, called glucose. A pound of glucose keeps more than another pound of real sugar, called sucrose, from crystallizing. If the cane juice has other impurities in it, these keep still more sucrose from forming crystals. Hence a cane juice showing no more than 10 degrees, Brix, would hardly be worth working for sugar, because low density always means high impurity of juice.

Grinding Season. - When frost comes, tremendous efforts are put forth by the sugar planters to grind all the cane before it begins to spoil. The mills usually rum only 75 days. The machinery is so massive and costly that the investment is very large in proportion to work done.

In the tropics, mills run 150 days during the year. In this country the short grinding season and the green condition of the cane make the manufacturing of the cane expensive. Good mills in the tropics have worked at a total manufacturing cost of about 60 cents a ton of cane 
handled, or about a quarter of a cent a pound for the sugar made. But in our sugar belt the cane is greener, the juices contain less sugar and need more boiling, the bayasse, or ground cane stalks, do not furnish sufficient fuel, so that the manufacturing cost of each pound of sugar is perhaps three times as great as it is in the best mills in the tropics. The large mills in Louisiana and Texas buy cane from the small farmers, paying about $\$ 3.50$ a ton for it loaded on the cars. With a thirty-ton yield, it should be a profitable crop to grow.

\section{QUESTIONS}

Where is sugar cane grown in the United States, and for what purposes is it grown? Where is it grown for sugar making? Does sugar cane mature in the Cnited States? What part of the cane do people of the tropies plant? Ilow is the sugar cane kept over winter in the United States? IIow is it planted? What sort of fertilizer does it need? What country grows the most sugar cane and rice per acre? Is sugar cane very hard to cultivate? How much cane does land make in the United States? Where are the yields largest? When does cane get sweet in the United States? How is sirup made from the cane? What kind of land makes the finest quality of sirup? What sort of instrument would enable you to boil your sirup just right? How can sirups be kept fresh? How was sugar formerly made in Louisiana? What is the principle of the vacuum pan, and why does it make more sugar? Why is the manufacture of sugar in the United States more costly than in the tropics?

Experiment. - If your father does not put up sirup in cans or sealed jugs, suppose you get a few clean bottles and new stoppers. Run hot sirup into these and stop up thoroughly while hot and keep till next summer, when barreled sirup is of bad quality. Show samples to your teacher and schoolmates. 


\section{CHAP'TER XXV}

\section{THE SWEET POTATO}

The Sweet Potato has always been an important crop' in the South. Thin, loamy soils produce fine crops of the very best quality. The long-leaf pine soils are ideal for this crop. When grown on heavy lime, clay, or bottom land, the sweet potato has a poor flavor, and does not keep well.

Varieties. - If, indeed, the farmer's of every community have not provided themselves with suitable varieties of other common crops, they certainly have done so with sweet potatoes. Perhaps the bunch, or vineless, yam has not been distributed so widely as its merits would justify. Experiments indicate that this kind makes better yields during seasons of drought than most of the other kincls. Then its bunch habit of growth permits better and late cultivation, and this of itself makes it stand drought better.

Preparation and Fertilizing. - The sweet potato neerls a good high ridge, or bed, to grow in. The soil should be plowed deep enough to prevent the potatoes from making above ground so as to be exposed to frost, fowls, animals, etc.; and at the same time shallow enough to prevent them from forming so deep in the ground that they will be cut by the plow in digging. 
Sweet potatoes do not need rich soil, and they are as easy to fertilize as cotton. Some two or three hundred pounds of good cotton fertilizer to the acre will be ample for this crop. Any thin land that will make a quarter of a bale of cotton to the acre will make fine sweet potatoes without the help of fertilizers, if it is first allowed to grow weeds a year or two.

Planting. - Some farmers plant the small, stringy

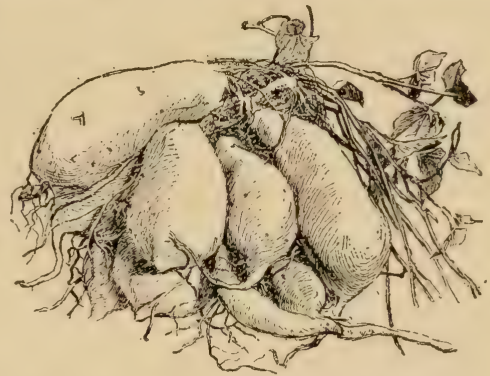

Fig. 62.- Hill of Sweet Potatoes potatoes, which they cut into little pieces and plant as they do Irish potatoes. A more general practice is to bed out the potatoes in early spring, laying them close together in a bed made rich with manure. They will sprout and make slips in April and May. These slips are pulled from the bed and transplanted in the field where they are to grow. More slips come up from the bed, and these are likewise transplanted. As soon as the slips in the field grow vines a foot long, these are cut and transplanted. The crop is thus multiplied from the bed and from the vines in the field, and sometimes plantings are continued into August in the Gulf and South Atlantic States. Potato slips or vines should be planted only in clean beds. Otherwise, the crop will become foul with weeds and grass, and this will greatly diminish the yield.

Labor in Planting. - The time required to set out the vines and slips is the greatest obstacle in the way of large 
1)lantings. The plants should be set two feet apart in four-foot rows. As the great bulk of the erop is planted from vine cuttings, much time can be saved by opening the row, or bed, with a small plow to receive the vines. Lay the butt ends of the vines across the furrow and step on them to press them down, letting the tops extend out over the edge of the furrow all on one side. Then cover by ruming a small plow on the opposite side of the furrow from the tops of the vines and throwing dirt into the furrow, but not far enough to cover the tops. By this plan, very rapid and satisfactory work can be done. Three or four hands and one horse can put out three acres a day.

Harvesting and Keeping. - Cultivation should continue as late in the season as the growth of the vines will permit. Though the vines make fine grazing for cattle, tramping is likely to bruise the potatoes so as to cause fungous diseases that make the potatoes hard to keep. The crop should be dug before a severe frost. If hard frost catches the crop in the ground, the ends of many potatoes will be injured, fungous diseases will enter, and the whole crop will be liable to rot.

If the vines are cut by a sharp rolling colter, or some similar tool run in each middle, they will not be difficult to handle. Whatever plow or digger is used, it should not be run deep enough to cut the potatoes or bruise them. Barring off with a turn plow and splitting the beds open with a big lister is a good plan. No other arrangement which the author has yet seen is better to keep the crop than the small cone-shaped "hill," or 
"bank," so made that the potatoes can be kept dry by layers of bark, straw, or corn stalks, and covered with dirt to keep out the cold.

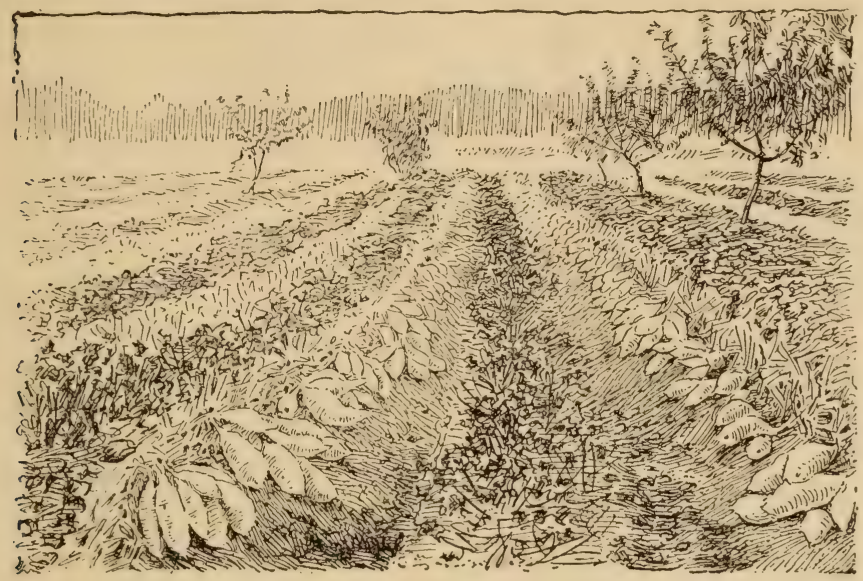

Fig. 63.-Digging Sweet Potatoes

Yield and Profits. - The sweet potato is now being largely shipped and sold at very profitable prices, bringing from 50 cents to $\$ 1$ a bushel at the shipping station. As 200 to 300 bushels are very common yields, it is easy to see that the crop is profitable.

Canned Potatoes. - Of late years, canning factories are buying large quantities at good prices, and putting them up as they put up tomatoes, corn, and other vegetables. No product keeps better in cans, and no canned goods are meeting a better demand. There is much more food value in a can of potatoes than in a can of tomatoes or corn of the same size, and the cost of canning them is comparatively small. Some farmers are buying small 
camning outfits costing from fifty dollars down as low as ten dollars, and putting up their surplus fruits and vegetables of all kinds.

As Stock Food. - As a stock food, the sweet potato is highly esteemed. About three and one-third bushels are equal to a bushel of corn in feeding value. If it were not for the extra trouble and expense of growing and handling a heavy, watery crop of this kind, and the uncertainty of keeping them sound, sweet potatoes might largely displace corn as a farm feed. At present they are often grown for hog feed, and the hogs are allowed to do the harvesting. As the hogs eat both vine and tubers, a reasonable acreage of potatoes can be grown very profitably for this purpose. I peanut crop near enough for the hogs to graze on will increase the good results, because the two foods together balance each other. If the two crops are separated by a fence, the hogs can easily be made to graze partly on each every day by simply shifting them from one field to the other.

\section{QUESTIONS}

How would you grow sweet potatoes? What arrangement is suggested for saving labor in planting out vines? Why not let cattle run over the potato field? How can potatoes be kept best? What is said of canned sweet potatoes? What is a fair yield for an acre of sweet potatoes? What amount of sweet potatoes would he equal to a bushel of corn for feeding? 


\section{CHAP'TER XXVI}

\section{THE COWPEA AND PEANUT}

The Cowpea. - This is one of the most valuable crops grown in any country. The farmers of the South, failing properly to estimate its importance, do not grow it as extensively as they should.

Varieties. - The value of this pea as hay, as a fertilizer, and as a crop in a rotation, has already been mentioned. There are numerous varieties, some ripening in seventy days from planting and others requiring the whole season. The cowpea was originally a tropical plant, and in the tropics varieties may now be seen that run over the tops of large trees, and have pods two feet long. In this country these kinds would be caught by frost before they matured seed.

Curing the Vines. - Pea vines are usually considered difficult to save for hay. If they are not cut until they get old enough for a few pods to ripen, the curing is not so difficult as it is generally supposed to be. One or two, and sometimes four, tons of hay, equal to clover and nearly equal to alfalfa in value, may be saved from an acre of pea vines.

Saving Seed. - The seed of the cowpea is now being saved in some of the states by mowing the vines when the peas are ripe, and running them through a threshing 
machine. This crop yields from eight to twenty-five bushels of seed to the acre. Where the seed can be saved cheaply, they are very profitable, as they sell for from one dollar to three dollars a bushel.

In the southern part of the Gulf States, two crops of some varieties can be raised in one year on the same land. One kind, a white, black-eyed variety, now being generally sold by grocers, is fast displacing the navy bean in the markets. This kind retails at about six cents a pound in the grocery stores. You might grow a crop and make some money from it.

Peas for Hogs. - This crop has for a long time been esteemed as a hog food. Certain experiments in Arkansas, Mississippi, and Alabama indicate that an acre of good peas gathered by logs will produce from 300 to 400 pounds of gain in live weight.

Cultivation. - Peas are often sown broadcast and plowed moler, but they do better if drilled in rows wide enough to permit cultivation. On thin land 150 pounds acid phosphate will make them yield a large crop. 'They need no nitrogenous fertilizer, as they can get nitrogen from the air. In some sections a little potash salt with the acid phosphate will be profitable.

Peanuts: Their Uses. - This crop has been grown rather largely in some of the states for a long time, but the United States has never grown more than enough to supply the demand for nuts for parching. Peanuts have been somewhat largely grown for hog feed, the hogs generally being allowed to gather the crop. Different experiments have usually shown that an acre of good 
nuts will produce about 500 pounds of grouvth in young hogs. Peanuts are also cured, vine, nut, and all, for hay for horses, cattle, and sheep. A good yield of this hay, when well cured, is two tons to the acre.

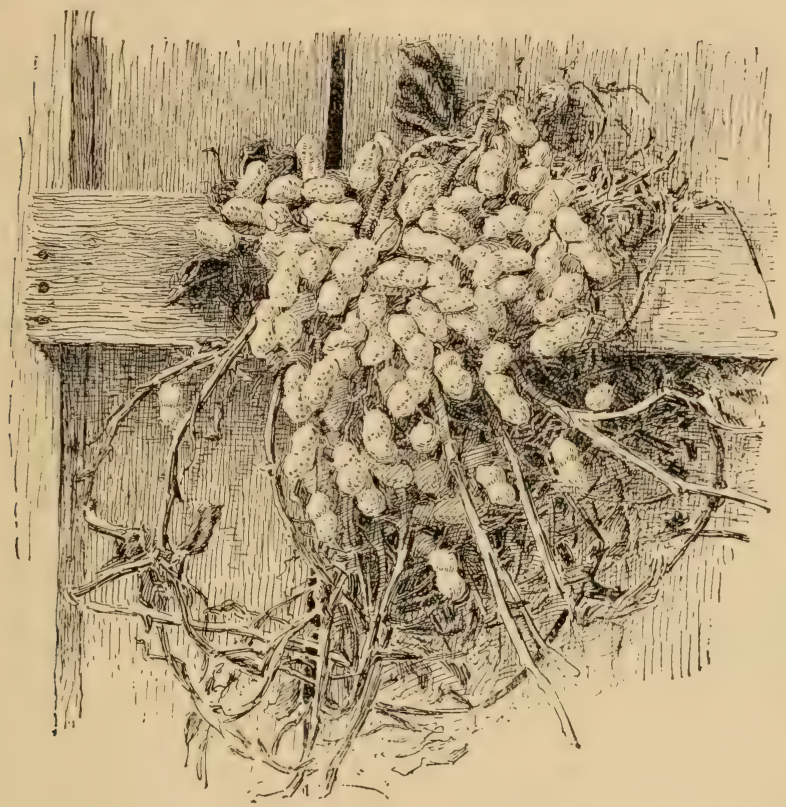

Fig. 64. - Spanish Peanuts

Varieties. - The variety generally grown for hay is a small, quick-maturing kind, called the Spanish peanut. When the vines are pulled up, practically all the nuts adhere to the vines. The nuts of this variety are shelled by machinery, and used in candies and confections, and for parching and selling as salted peanuts. Somewhat larger kinds, one of them being called the Virginia nut, are 
grown more largely for the parching trade, and have been bringing a very high price for some years.

Climate and Soil. - All the uplands of the South and Southwest are well suited to this crop. The light-colored, sandy lands make the smoothest and cleanest nut for the market, but clay and lime lands make larger yields. In the sections infested with the boll weevil there is great interest in this crop as a market crop.

Peanut Oil. - If more nuts are produced than the parching trade will take, the cotton-seed oil mills, with the

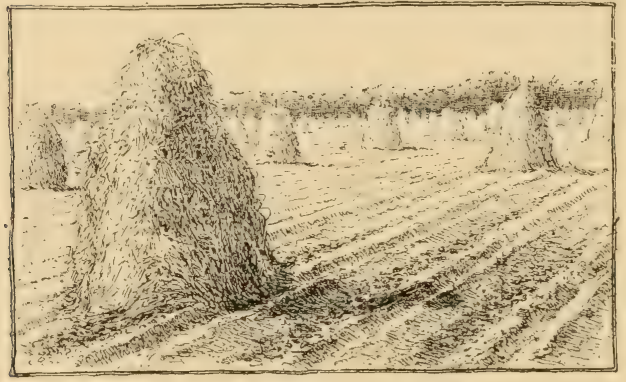

Fig. 65. - Saving Peanuts addition of a little extra machinery, could crush them for oil and cake. A bushel of nuts will produce from one to one and a half gallons of oil and ten to fifteen pounds of cake fully as rich as cotton-seed cake. Peanut oil is a highpriced oil, and the cake is worth more than cotton-seed cake, because it is suitable for feeding horses and hogs. At prices lately prevailing for peanut oil, the mills could afford to pay from sixty to seventy-five cents for a bushel of nuts and still make a very fair profit. At such prices a good profit could be made by the grower, as fifty bushels can easily be made on an acre, and the crop can be threshed cheaply by machinery. An acre of peanuts will 
yield about a ton of good hay or straw, in addition to the nuts.

Cultivation. - Peanuts, like peas, need only acid phosphate or phosphate and a little potash salt as a fertilizer. Occasionally lime may be needed on very sandy land to make the larger kinds fill their pods well.

Peanuts are often grown in corn, or after oats, just as peas are, and sometimes take the place of peas in the rotation of crops. They are more expensive to grow than peas, as they need more hoeing. Good, well-selected, clean peanuts are selling in Southern cities for eight cents a pound. Suppose you grow an acre, making fifty bushels, how much money could you make?

\section{QUESTIONS}

What are the many uses of the cowpea? What suggestion is made for saving the hay? What sort of machinery is being used to save the seed? Where can two crops of cowpeas be grown on the same land in the, same season? What article of food is being displaced by the cowpea? How much pork will an acre of cowpeas produce? What fertilizer would you use for peas? What are the uses of the peanut? How are they handled as stock food? What kind are generally grown for stock food? IIow are peanuts shelled? What kind is grown largely for parching? What sort of land makes the best market nut? What kind of land will make largest yields? How could oil mills handle peanuts? How much oil and cake would a bushel make? What value ought this to give the peanut for crushing in the mills? How much vines or hay will an acre make? 


\section{CHAPTER XXVII}

\section{TOBACCO}

Tobacco is one of the big crops of the United States. A very large amount of tobacco is sold for domestic use and for export; also cigar tobaceos of such qualities as are not grown in this country in sufficient quantity are imported in large quantities.

Tobaceo was being grown and used by the Indians of both North and South America when Europeans discovered the Western World.

When Magellan discovered the Philippine Islands in 1521, his ships first anchored in the Bay of Cebu, where the king of the Philippines lived. 'The king sent his most trusted minister out to see what mamner of visitors had come. The minister in his little boat circled around the ships nearly all night, and observed closely all that took place. Before day he went back to shore and reported to the king that the new-comers were great, white giants with hooked noses and red eyes, who ate stones, drank fire, and blew smoke out of their nostrils. On receiving this report, the king killed a large number of carabao (water buffalo) and pigs, prepared a great feast, inviter the Spaniards ashore, and gave them the country.

As Magellan's expedition had tarried some weeks in Brazil, where the sailors could have learned to smoke, they 
probably were smoking, and this gave rise to the wonderful story about their drinking fire and blowing smoke out of their nostrils.

Influence of Soil. - Very few plants are so much influenced by the kind of land they grow on as is tobacco. If the seed of Havana cigar tobacco, which is grown on sandy land, is planted on the stiff clay and limy land that grows the heavy chewing tobaceo well, it will make a tobacco more like chewing tobacco than cigar tobacco. The slightest change in soil materially changes the grade of tobacco.

The great bulk of the chewing tobaccos are grown in Kientucky, Virginia, Maryland, Missouri, Tennessee, and North Carolina. The states of Pennsylvania, Connecticut, Ohio, Wisconsin, and New York grow large quantities of cigar tobacco.

Shade-grown T o b a c c o. Some very fine cigar tobacco is

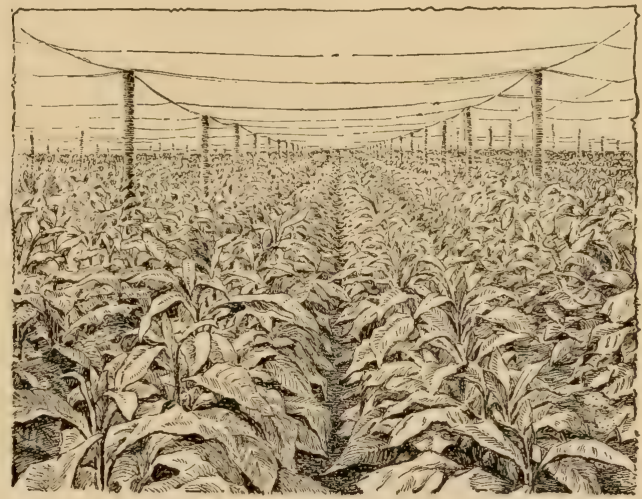

Fig. 66. - Tobacco growing under CheEse-cloth SHADE

being grown under partial shade in Georgia, Florida, Alabama, and Texas. These tobaccos are grown on welldrained loamy or sandy types of land. 'The field is entirely covered with a thin cheese cloth supported on suit- 
able framework. Sometimes the frames are partially covered with narrow slats that shut out part of the sunlight. This partial shade makes the leaf thin and of most desirable quality. The covering protects the crop from being whipped by winds, and to some extent from insects. Often the expense of covering the land and producing the (rop amounts to several hundred dollars an acre. This investment is, however, profitable, as it sometimes assures the prorluction of a crop of 1,500 pounds of tobacco, worth from twenty-five cents to one dollar a pound.

Sumatra Tobacco. - Good Sumatra wrapper leaves for cigars cost the manufacturer, after paying duty, about $\$ 3.00$ a pound. But the leaves are so fine and thin that a pound will wrap from 500 to 1000 cigars. The planters of Simatra use Chinese labor under a system of peonage that assures extreme care in handling the tobacco at every stage, and hence they make the finest leaf in the world. ()rdinary American-grown wrappers require six to eight pounds to wrap a thousand cigars.

The shade-growing method enables Southern growers to make leaf approaching the Sumatra leaf in value. Havana tobacco is also eoming to be largely grown on the light lands of the South. It makes a filler tobacco nearly as good as the Cuban product. Grown under partial shade, the Havana tobacco turns out a good proportion of desirable wrapper leaves.

Fertilizing. - Tobaceo needs liberal fertilizing, and is generally supposed to need a good percentage of potash in its fertilizer. It contains an unusually large percentage of potash, as well as nitrogen, but the analysis of a crop is 
not always a safe guide as to its fertilizer needs. This potash should never be in the form of potassium chloride, or the tobaceo will not burn well. Potassium sulphate is the form in which the potash should be applied. Tobaceo grown within five or ten miles of the sea contains too much chlorine to burn well.

Tobacco growing and handling must be specially studierl in order to be well understood. Students should send for bulletins of the Department of Agriculture and of the Experiment Stations of the states that grow large quantities of tobacco.

\section{QUESTIONS}

Where was tobacco originally found? What story is told of Magellan's discovery of the Philippines? What kind of land grows heavy chewing tobacco? What kind of land grows the cigar tobacco? What states grow most of the chewing tobacco? Tell where shadegrown tobacco is made. Give an idea of the expense and returns on shade-grown tobacco. Where and under what conditions is the best cigar tobacco in the world grown? What precautions must be taken in fertilizing tobacco? 


\section{CHAPTER XXVIII}

SORGHUM, KAFIR, AND MILO-MAIZE

Origin, Uses, and Adaptability. - These three, together with chicken-corn, broom-corn, doura-corn, etc., have been grown for ages in the East Indies and in Africa. The sorghums have been cultivated largely in the United States only during the last twenty year's. At first the sweet sorghum was grown mostly for sirup-making, but is now more largely used for hay. The non-saccharine kinds are very largely cultivated for grain in the semiarid parts of the IV est, where Indian corn is uncertain. Although tropical plants, these sorghums have made themselves perfectly at home in the northern part of the United States, and will flourish where the climate is too cool for Indian corn. Their great feature is their ability to stand drought. They appear to become almost dormant in a dry time and to wait for weeks, and even months, for rain; and, after being watered, they grow remarkably, and make good crops. These plants can also stand wet conditions better than most plants; they will grow on poorer land and with poorer culture than most crops, and will stand considerable alkali. They are great, hardy, vigorous, giant grasses that thrive under most all conditions. The tremendous growth in the cultivation of these sorghums in late years has been one of the marvelous things about American agriculture. 
For Hay. - The sweet sorghum is largely sown broadcast or drilled like wheat, at the rate of about a bushel of seed per acre, to make hay. It generally produces two ('rops of hay in the season, if planted early. In the Gulf States it is often planted about April. In the states farther north, May and June plantings will be safer. This plant makes large crops of coarse but nutritious hay. For

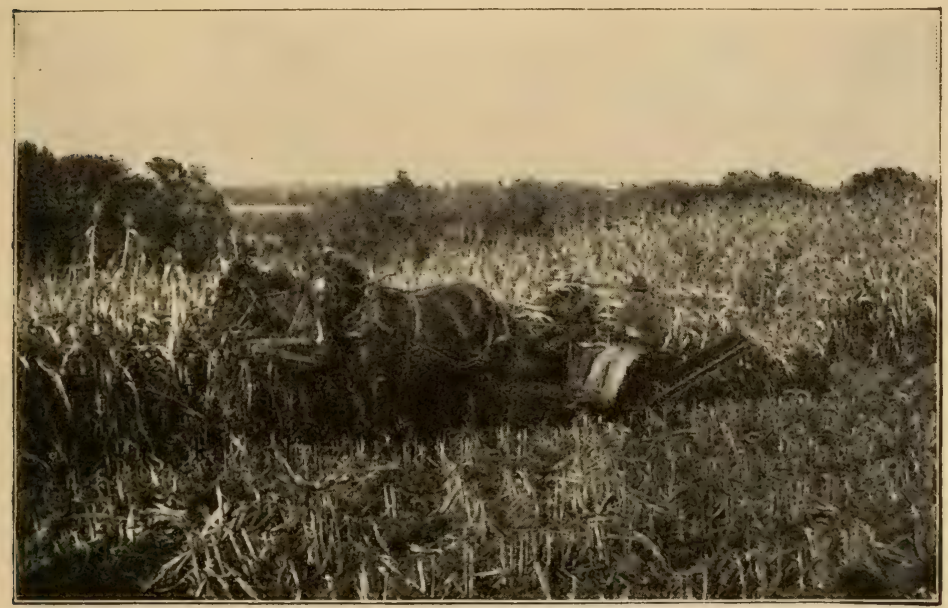

Fig. 67. - Harvesting Sorghum

early plantings it is necessary to sow it thick so the stalks will be small. Otherwise the stalks will be too coarse and woody to be eaten well when they get dry. Where sorghum can be matured just before frost, large stalks may be cut and stacked, and it will keep well all winter with the juice in the stalks, and is greatly relished by stock. In the dry belt sorghum ought to be planted in drills wide enough to be workerl a little, if possible, in order to save moisture. 
Planting and Culture. - The non-saccharine sorghums are usually planted in drills. A favorite plan in the dry country is to run a lister with a planter attachment so as to drill the seed in the bottom of the lister furrow. This plan assures a stand, and the gradual working of dirt to the crop makes it stand drought well. On the plains these crops are often put in by sowing seed in every third or fourth furrow made by a turn plow while breaking the raw sod. The next furrow covers the seed with two or three inches of turf, and not another stroke of work is done until time to gather the crop. 'The hard, unbroken soil at the bottom of the shallow plow furrow appears to be suitable feeding ground for the roots of these hardy plants, and the coating of unrotted grass sod appears to let in the rain water and to serve as a mulch to keep the water from evaporating. Excellent crops are made in this way. As land becomes older and weeds begin to appear, regular cultivation becomes necessary.

Kafir and Milo Maize. - These crops always make more grain per acre than Indian corn, and when seasons are unfavorable may make twice or three times as much. They are often cut near the ground with corn harvesters and shocked in the field. From the shocks the grain and the stover are fed; sometimes the cattle are turned in to help themselves and sometimes it is hauled to them. When the grain is fed whole to cattle or horses, a great deal of it is undigested; but if fed in winter there need be nothing lost. The undigested corn keeps perfectly in the dry, cold winters of the plains until found and eaten by hogs and fowls. The planting of these crops is done late 
enough so they will ripen just before frost. Then if any grain is knocked down, it keeps. If labor is scarce, horses and cattle are turned on the field to do the harvesting. What they trample down keeps perfectly for the hogs.

Grinding. - These erops are made about as digestible as

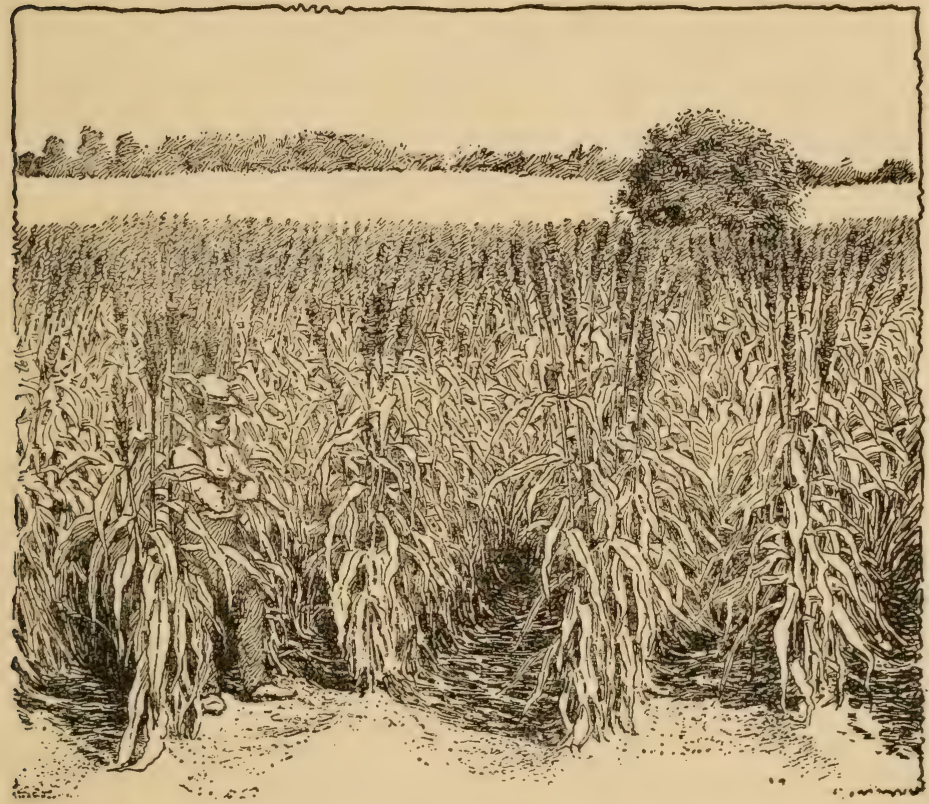

Fig. 68. - Field of Kafir Corx

Indian corn by grinding. In fact, all experiments indicate that ground kafir or milo is about nine-tenths as valuable, pound for pound, as corn meal for feeding animals. Some people, therefore, thresh and grind these crops. To save the expense of handling too much stover, some have little attachments fastened on to a wagon bed for cutting the 
liearls and loading them on the wagons. In this shape the grain is easy to handle and thresh and grind.

Diseases. - In the humid sections of the South, where only the sweet sorghum is grown to any extent, the seeds lave been blighting of late years, so that the people cannot save their own seed. These are bought, usually from western Kansas and Oklahoma.

Grazing. - Occasionally sorghums are planted thick for grazing, and, if not grazed too closely, stand this treatment well. It is used more for grazing hogs than for the other stock. Hogs are turned on it when the crop is knee high, and continue to graze it until it ripens, when they chew it and eat the seed.

Poisons in Sorghum. - Green sorghum has often killed cattle. This seems to be caused by the poison called "prussic acid" that is occasionally found in green sorghum, especially at the end of a long drought. The East Intlian farmers knew of this poisonous property of sorghum ages ago, and learned to cut and partially dry the feed before giving it to their oxen and buffalo. By partial drying, the poison disappears in large measure.

Sorghum Alcohol. - Sweet sorghum is seriously considered for making alcohol for cooking, heating, lighting, and power on the Plains, where fuel is scarce and expensive. An acre of good sorghum would easily produce two hundred gallons of pure alcohol, and the expense of manufacture is not great. Where other fuel is so costly, alcohol may easily be worth thirty to fifty cents a gallon for many uses. Broom Corn is now being largely grown in West Texas, Oklahoma, and Kiansas. Being a sorghum, it 
stands drought well, and cures beautifully in the dry climate of the West. No sheds are needed to cure the brush into the best quality of product. A fair yield is 700 pounds an acre, worth three or four cents a pound.

\section{QUESTIONS}

What two classes of sorghum are there? Give the origin of these crops. Where are they largely grown? For what four purposes are they grown? Under what extremes of climate and soil can sorghums thrive? In what ways are these crops planted? How are they gathered? Why is there little loss of these grain crops on the Plains? How do the people harvest and handle the grain? What of the comparative yield of Indian corn and kafir? What of the comparative feeding values of Indian corn and kafir? Tell something of broom coru. 


\section{CIIAPTER XXIX}

\section{THE VELVET AND SOY BEANS, ALFALFA, HAIRY VETCH}

Velvet Bean. - This is a large tropical bean that makes vines as large as a plow line, and often fifty feet long, bearing seed in pods covered with a fuzz resembling velvet.

This bean needs the whole season to grow in, and even then does not mature seed farther north than Florida and South Texas. It neerls a little cultivation till it begins to cover the ground, after which it makes a dense mass of tangled vines and leaves, some three or four feet deep. No other crop grows better on poor sandy land, makes such a dense shade, or accumulates so much nitrogen from the air. As before stated, an acre will contain two humdred pounds of nitrogen, worth at commercial fertilizer prices, thirty-six dollars.

The vines are seldom cut for hay, but are pastured by cattle. The enrichment of the land is usually the main object. In Florida, large crops of the seed are gathered and ground into meal, which makes a rich food for stock.

The few seed necessary to plant an acre are not expensive, even where they must be purchased every year.

The Soy Bean. - This is a Japanese bunch bean. It is extensively cuitivated in Japan and China for the oil that is pressed from it. In some parts of this country it is 
ground into meal and mixed with corn meal for hogs and other live stock. A little soy-bean meal added to the feed of live stock never fails to give an increase or gain in weight. This is due to the large amount of protein and oil in the bean. The soybean vines, or straw, do not make as good feed as cowpea or peanut vines. The crop has not become very popular south and east of Kansas ancl ()klahoma.

\section{Alfalfa : Culti-} vation.- No erop has attracted

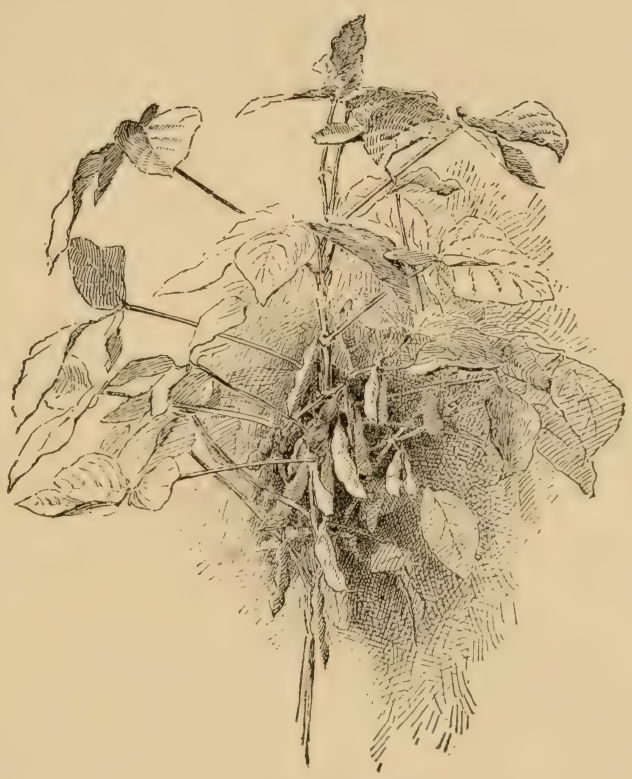

Fig. 69. - SoY BeAx more attention, and no crop has been tried oftener and has failed more frequently, than alfalfa. As it needs very rich land, it does remarkably well under irrigation, on the arid and the semiarid land in the West. In the East it is probable that the only lands rich enough for it are the lime prairies and the buckshot bottoms. There are some indications that it is a plant which requires large amounts of lime in the soil. When young, it is extremely tender, and easily 
killed by grass and weeds. The crab grass of the sandy lands of the South will soon choke it out.

Alfalfa does best when seerled in the fall. In the Gulf States, if the land is kept clean of weeds and grass in the spring and summer, and plowed and harrowed until planting time in September or October, the best success may be expected. It is a mistake to recommend the

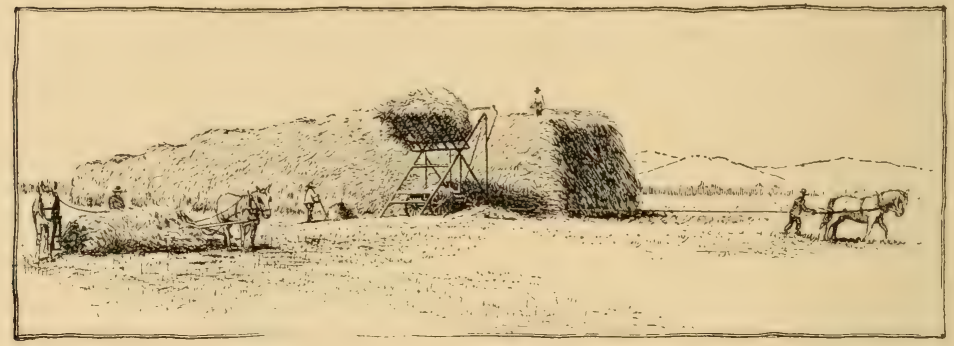

Fig. 70. - Stacking Alfalfa Hay

planting of alfalfa on ordinary sandy, loamy, or clay land outside of the arid and semiarid sections.

In some of the arid sections alfalfa is known to have lived and grown thirty or more years from one planting. In dry, porous soils its roots have been known to grow forty feet deep. In the humid sections thirty pounds of seed per acre are recommended; in arid sections half this, as all crops stool and sucker more on rich arid lands. Seed should be planted as carefully as turnips are planterl.

Uses; Curing and Saving Hay. - Where it does thrive it is a crop of great value, giving each year four or five cuttings of the finest hay known. It also greatly improves the fertility of the land. In the humid sections considerable 
trouble is experienced in saving alfalfa hay. The heaviest crops are in the spring, when conditions are not good for curing hay. One plan practiced with success is to throw it into cocks, or tall piles, of two or three hundred pounds each when it is partially cured and cover each pile with a cheap (ap) of cloth or paper and let the hay remain ten days or two weeks, when it is put in barn or stack. No certain rules that will fit everybody's case can be given for saving hay. All hay in humid climates should be stacked a month before baling.

Hairy Vetch; Habits and Uses. - In order that this urop, which has already been mentioned, may not be confused with other vetches, its scientific name, Vicia villosa, is given. The seed should be sown in the fall at the rate of from a half-bushel to a bushel to the acre, about as oats are sown. It makes only a small growth in winter, but in early spring it grows with remarkable rapidity. By May, in the Gulf States, it is ready to cut for hay. It dies in June, shedding its crop of seed on the ground; these seed come up in the fall again, and thus the vetch becomes a wild plant, but it is never hard to get rid of. If it is eut for hay before it makes seed, or if it is grazed closely by stock, it disappears. Plowing it under as a green manure before it seeds also kills it.

Close grazing in winter and early spring does not hurt it. If stock are taken off it before it gets ready to make seed, it recovers with remarkable rapidity.

The best way to start the vetch is to mix about fifteen pounds of seed to two bushels of oats and sow to each acre. After the first sowing the vetch will come up each fall. 
Sorghum may be grown between the crops of vetch. The vetch is a more vigorous grower than the bur elover, and enriches the land faster. It flourishes on all classes of fairly well-drained land.

\section{QUESTIONS}

Tell something about the relret heatn. What is it particularly raluable for? Where is the bean made into meal? Where does the soy bean come from? What is its special value in producing a mixed feed? What ingredients of feer stuff is the soy bean rich in? Where in the United states has alfalfa proved a certain crop? Where has it proved uncertain? Does it need rich land? What lands in the Southern States have grown it well? ('an it stand weeds very well when Foung? At what season should it be seeded? How should the land he treated during the summer before seeding? Is alfalfa likely to suceed on ordinary sandy and loamy lands? Does it improve the land, and if so, why? Is it very difticult to save for hay? What sort of plant is the hairy vetch? When does it make its growth? Will it sow its own seed and come every year after once being seeded? Is it very hard to get rid of? What crop is it easily started with? What rop may be grown on the land after the vetch dies in the spring? 


\section{CHAPTER XXX}

\section{THE CLOVERS AND MINOR CROPS}

Red Clover. - This plant thrives in the northern and eastern parts of the Uniterl States, and does well as far south as Temnessee and as far west as Kansas and Oklahoma. The crop is not a reliable one for the Gulf States, and is not grown largely in the West, where alfalfa thrives best.

This plant requires fertile soil and careful preparation of land. Much of the soil of our Southern States is said not to be good enough to grow it.

Red clover is a biennial ; that is, one planting makes crops for two years and dies. It makes big crops of hay and a large growth of root

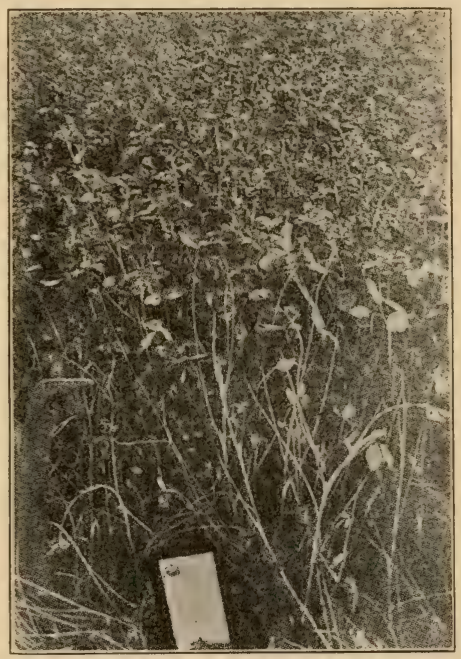

Hig. 71. - RED Clover and stubble. As it secures nitrogen from the air, its roots and stubble greatly enrich the land and make it open and porous. Corn grown on clover sod always makes a large yield. 
In some parts of the North red clover is used in the following rotation: two years clover, one or two years corn, one year wheat or oats, and perhaps one year of Irish potatoes. The fall is much the best time to start red clover in the southern part of its territory. Fifteen pounds of seed to an acre sown on land well enough prepared for turnips should bring success, if the land is of suitable kind.

Bur clover is an annual; that is, it comes uy in the fall, grows all winter and early spring, and dies, root and top, after making seerl that are shed off on the ground. Cattle do not appear to relish this plant as they do some others, but they have been known to winter on it and be in good condition in the spring. It is seldom or never cut for hay. Bur clover grows on almost any kind of soil. The author has seen it grow well on strong lime lands and on the poorer sands of the longleaf pine region. Wherever in the South there is rain enough to bring it up in the fall it will grow to advantage.

Bermuda sod is an ideal place for bur clover, bechuse the clover dies about the time the Bermuda is ready to grow in the spring. The Bermuda turf prevents the cattle from logging when they are grazing the clover in the winter or spring.

Bur clover may be grown in rotation with sorghum or other crops which bear late plinting. The sorghum may be planted in May after the clover is dead. The clover seed shed in the spring will come up in the sorghum stubble when the fall rains come, and enrich the land for the next year's crop of sorghum. 
Crimson Clover. - This is an annual clover that is often planted in the fall in Maryland, Virginia, and other states. It is frequently sown in corn during the last working in August, and used as a winter cover crop to protect the land and enrich it. It is lighly recommended for sowing in orchards, as it completes its growth and dies in early spring before the orchard begins to need moisture. Crimson clover is sometimes saved for hay, but is more often used for grazing.

It has not generally succeeded in the central and western Gulf States, where the bur clover appears to be a much hardier and more desirable plant.

\section{Mammoth Clover. -} This giant red clover is

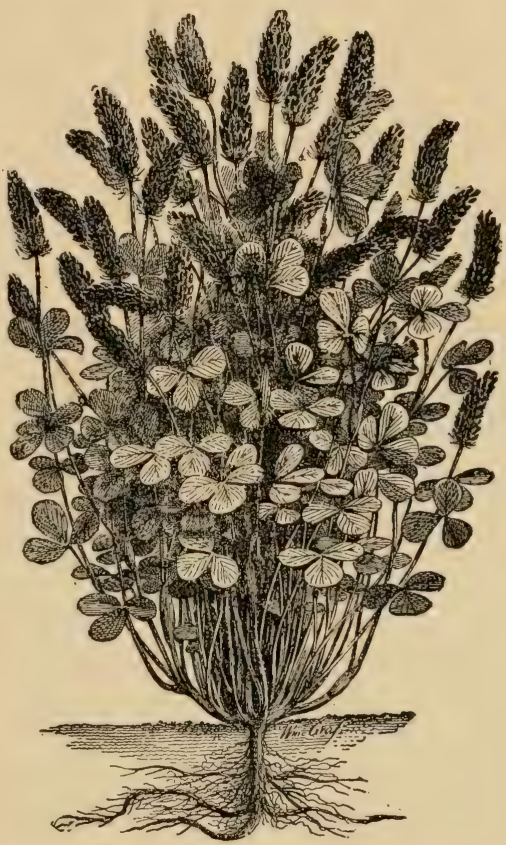

Ficx. 72. Crimsoy Chover

a much larger, coarser plant than ordinary red clover. The stems are so coarse that it does not make so good a quality of hay as the smaller kind. It is grown largely for green forage and for enriching the land.

Melilotus or Sweet Clover. - This plant is regarded as a weed in the North. In the South it grows only on 
rotten lime-rock land, or other land rich in lime. It will grow on bare lime-rock, if it ean send its roots into a crack of the rock: As it makes an enormous growth, and gets nitrogen from the air, it helps to restore fertility to poor land. It is a biennial, and makes the largest growth in its second year.

While it is not relished by stock, as some plants are, it is very nutritious. It is used both for grazing and for hay. When

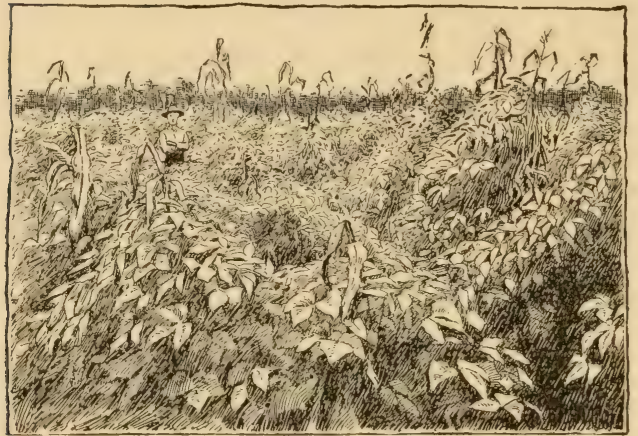

Fig. 73. - Florida BegGiar WeED once started on poor, washed lime land, the plant keeps growing as a weed until killed out by grazing or by cultivation. Seed may be thrown on land without preparation at the rate of fifteen pounds per acre. Better results are secured if land is plowed or disked.

Mexican Clover. - This plant, which is not a true clover at all, flourishes in the sandy, cultivated lands of South Georgia, Florida, and the southern part of the other Gulf States. It is an anmual that comes up in the cornfields after the corn is laid hr, and in oatfields after the oats are cut. It makes excellent hay, which is generally cut and saved late in the fall.

Florida Beggar Weed. - This plant also flourishes in 
sandy lands, coming up volunteer late in the season on cultivated fields. It is found mostly in Florida, South Georgia, and Alabama. It is a true legume, and hence enriches the land it grows on. It makes good hay and grazing.

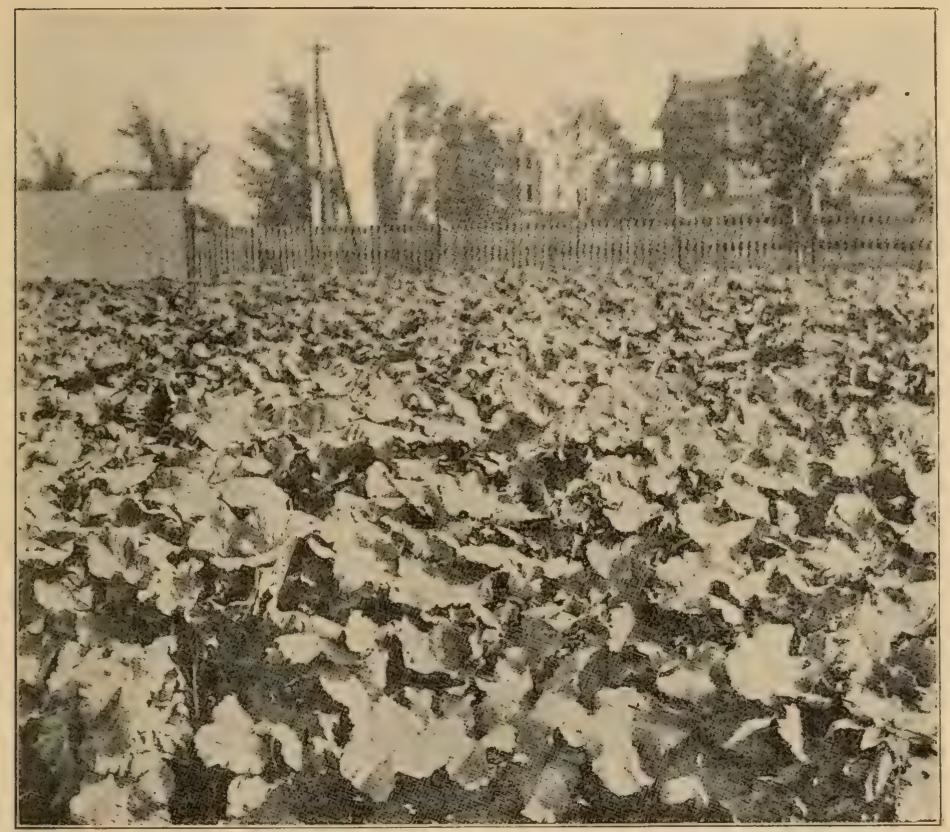

Fig. 7t.-RApe Field

Rape. - Belonging to the same family as the collard, cabbage, and turnip, rape is a fine forage plant for hogs, and especially for sheep. It makes its best growth when sown in the fall on rich and well-prepared land. When it is large enough for good grazing, hogs and sheep are turned on it and allowed to eat it down somewhat closely. 
It sprouts out again and continues to grow. It has often been found to afford food equal in value to peanuts and cowpeas, although in order to fatten hogs it needs supple-

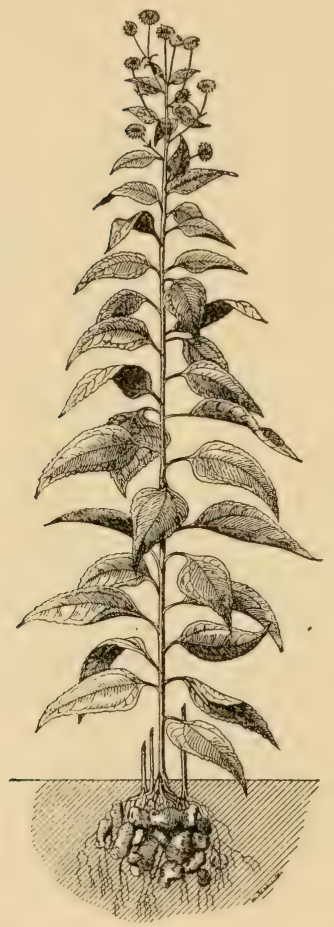

Fig. 75. - JERUSALEM ARTICHOKE menting with grain feed. It is sown in the same way as turnips.

Chufas, or Grass Nuts. - This is a crop often grown for hogs on the thin, sandy lands of the South. It is greatly relished by hogs, and they root up the crop of sweet, juicy nuts. The chufa is not quite so valuable for pork-making as peanuts, and it is exhaustive to the land. 'The crop keeps well in the ground all winter, however, and this affords good feed for hogs after the Spanish peanut has rotted.

The chufa, being very sweet and agreeable to the taste, is cultivated and sold in Spain for human food. It is planted very much as peanuts are.

Jerusalem artichokes are planted and cultivated somewhat like the Irish potato. They make large crops of fleshy, starchy tubers, fully as nutritious as Irish potatoes. They are grown to afford grazing for hogs, but are not relished well enough to make a fattening food like sweet potatoes. They keep well in the ground all winter. The artichoke and chufas 
are good late winter pasture erops. 'They may be grazed by hogs after peanuts and sweet potatoes are gone.

\section{QUESTIONS}

Where is red clover largely grown? Does it need good soil? Is red clover an annual, a biemnial, or a perennial? Does the red clover improve the land? Tell something of the bur clover. When is it planted? When does it grow and die? Is it suitable to all kinds of land? IIow does it do growing on Bermuda sod? What other crops can be grown on the land after the bur clover dies in the spring? Will it come up volunteer in the fall when once seeded? What is the habit and growth of the crimson clover? Has it proved as successful as the bur clover? What sort of land does melilotus, or sweet clover, grow on? Is it a good crop for some land? Where is the Mexican clover grown? Where is the Florida beggar weed grown, and of what use is it? Describe the rape, and tell what it is grown for. Of what use are chufas, or grass nuts? On what kind of land do they grow especially well? What is the Jerusalem artichoke? 


\section{CHAP'TER XXXI}

\section{OTHER HAY AND PASTURE GRASSES}

The Bermuda grass is one of the best pasture grasses, if not the best, for the (xulf and South Atlantic States and for parts of Tennessee, Arkansas, and Oklahoma. In the higher and colder parts of the Plains, it cannot compete with the native buffalo grass. Although a great droughtresisting grass, it probably does not equal the buffalo and mesquite grasses in this respect. Where Bermuda grass thrives, it is the very backbone of the entire pasture system. It will pasture more stock to the acre without being injured, stand more drought, and afford more months of grazing in the year than any other one grass or plant.

Value for Pasture and Hay. - People of the Mississippi Delta in Arkansas, Mississippi, and Louisiana have frequently reported that their Bermula pastures afford grazing for five head of cattle or horses to the acre from April to Christmas. Good land makes large crops of Bermuda grass hay, which is easily saved and fully equal in value to timothy hay. 'The yield is often from two to four tons an acre. As Bermuda grass does not mature good seed in the United States, there is no danger of its spreading like Johnson grass, when used for hay.

Bermuda grass used to be dreaded as Johnson grass is now; but people have learned to work with it, and to kill it when it has served their purposes. Besides the plan 
already given, it may be destroyed by heavy crops of peas, velvet beans, or sweet potatoes, that shade the land well all summer.

On the clay, lime, and bottom lands white clover should always be grown on Bermuda pasture. The clover grows when the grass is dormant, and lengthens the season of good grazing about two months. This gain of two months' grazing in early spring means much to the Southern farmer. It means he can have his cattle almost fat before heat, flies, and ticks appear, and that he will be saved two months' expensive feeding. 'The white clover, once established, will last forever. 'This gives a natural rotation of crops; the clover, growing in winter and spring, enriches the land for the grass which grows in summer and fall. Toward the northern limit of the Bermuda area the blue grass begins to thrive, and may often grow on the Bermuda sod.

On the sandier and poorer lands bur clover will thrive better than white clover, and should always have a place on Bermuda pasture.

Carpet Grass. - In the sandier districts, particularly in the southern part of the Gulf States and the pine belt of the South Atlantic States, carpet grass disputes very successfully the possession of the soil with Bermuda. It occupies the little bottoms, hollows, and firmer uplands, wherever grazing is done. When the land is cultivated or allowed to grow up in weeds, the carpet grass risappears. Is soon as cultivation ceases and stock begins to graze and tramp down the tall weeds and brush, it comes again from seed that are scattered over the comn- 
try. Carpet grass stands the heaviest grazing and tramping, and affords a longer period of grazing than Bermuda.

Japan Clover, or Lespedeza. - Beginning with East Texas and extending all over the rainy sections of the South, this little legume flourishes on the roadsides and in almost all pastures. On good land it sometimes grows high enough to make fine hay. It often grows with carpet grass and sometimes with Bermuda. It is a summergrowing annual that is late in getting large enough for grazing in spring, and is killed by the first frost in fall. It makes fine summer grazing, and comes up and thrives without sowing.

Johnson Grass. - This grass generally comes without being wanted. It is not often used for pasture, except as a means of killing it. It does not stand close grazing, and is easily killed out in two or three years by this treatment. However, a few people who want to graze it and preserve it, divide the pasture, grazing part at a time. In this way it lasts indefinitely and affords fine grazing.

Johnson Grass Hay. - This grass is generally used for hay, yielding each year three or four cuttings of hay that is rather better than timothy. The hay is very likely to carry some ripe seed, and the grass is often spread in this way. For this reason many people will not buy the hay or allow it to be brought into the community. This gives it a lower price than its feeding value would justify.

Killing Johnson Grass. - After Johnson grass has been closely mowed for hay two or three years, it becomes so weakened that it can be easily killed. It gives most trouble when it appears in patches on cultivated 
land. The bunches should be torn up with plows and the hoe hands should cut them considerably below the surface of the ground. By frequent careful working until late in the summer, the grass can be killed even without grazing or mowing. Farmers in Mississippi and Alabama are killing it in this way every year. If any plant can be kept cut off under the ground often enough to prevent any top growth, the roots will die.

Another way of getting rid of this grass is to grow no

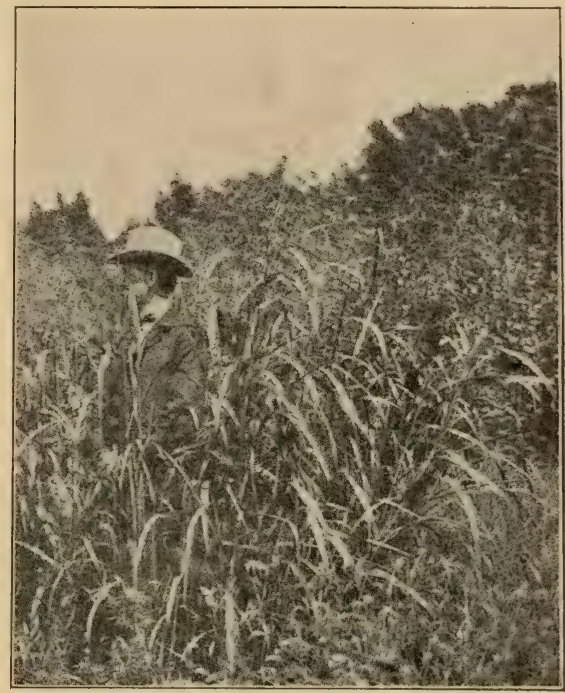

Fig. 76. - JoHnson Grass crop on the land and plow it several times in the summer. This treatment is expensive, but it puts the land in the best possible condition for a fall crop. Again, Johnson grass land may be reclaimed by sowing fall oats or wheat and plowing soon after harvest in June, and then keeping it clean of the grass by frequent plowings, say once every three weeks, till October. Sharp, heavy disk harrows, set to run at the greatest angle, will probably cut off the grass at each operation after the first plowing. In summer Johnson grass roots (rather, underground stems) rot 
rapidly. Unless there is a green growth of leaf to gather food and produce more roots, the grass must die. This is true of any plant.

Chemicals. - All chemical treatments for this, or any other deep-rooted pest, are entirely too expensive. It is

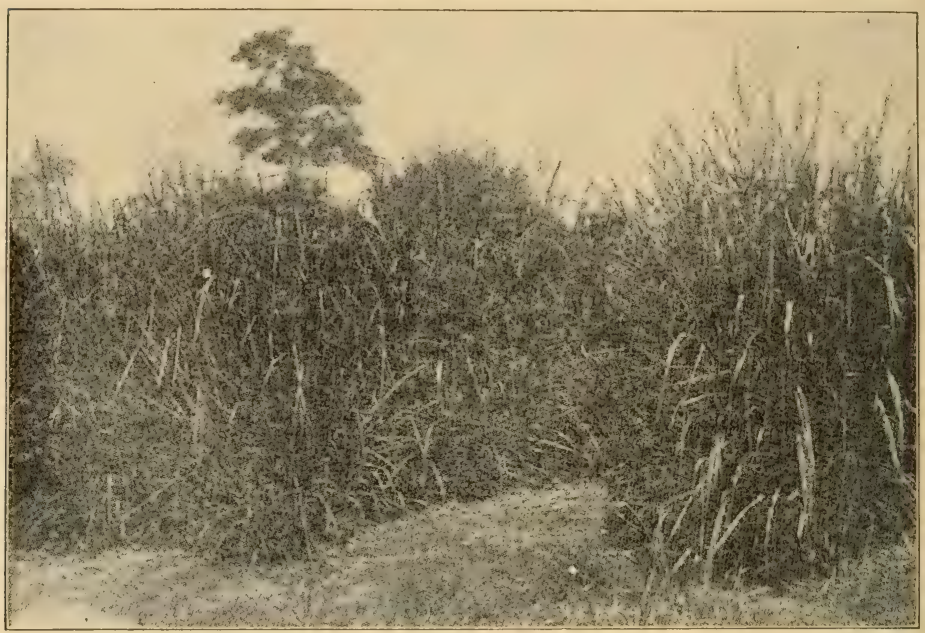

Fig. 77. - Guinea Grass, Biloxi, Mississippi

probable that a thousand dollar's' worth of the cheapest chemical obtainable would not kill the grass on an acre. If it did, it would kill the land for two or three years.

The people who have had this grass longest in the United States have learned to utilize it and to kill it, and its presence in those sections does not reduce the value of the lands on which it is found.

Guinea and Para Grass. - Guinea and Para grass, both large tropical grasses growing as high as a man's head, and densely thick on the ground, are becoming well 
known and appreciated in the Gulf States. Neither of these grasses propagates in the same way as Johnson crrass, and neither is likely to become a pest. The Guinea grass spreads from seed, and the plants sucker enormously; several hundred plants come from one stalk. The Para grows from large trailing stems in the same way that Bermuda does, but much faster. Its stems will often grow thirty feet in a season, and make a new plant at each joint. Both of these grasses remain remarkably suceulent and tender for grasses of such size.

They are very useful for hay and for soiling, and cutting and feeding green to stock. They are also fine for grazing. The Guinea grass is the main grazing grass of Cuba, and the Para of South America. Both of these plants will become of great value in the southern part of the cotton belt.

Crab Grass. - Crab grass is found everywhere on cultivaterl land in the sandy, loany, and clay sections of the Sonth, east of the semiarid belt. It does not flourish on lime lands or on buekshot bottoms. It is often eut for hay, particularly when it grows with peavines. It gets into cultivated lands the second year after they are cleared. W'hen cultivated land is converted into pasture, crah grass makes good grazing for one year, when it gives way to other growths.

Expense of Cultivating. - ('ral) grass adcls more to the expense of cultivating the (rol' than any other pest, except coco (nut grass) and Johnson grass. It seems to exhaust the land and hurt the crop) much worse than Bermula, coco. or even Johnson grass. ('mal) grass will 
always kill alfalfa, but on suitable land the latter grows well with Johnson grass. Crops often grow well in the midst of coco and Bermuda, but never with crab grass. Any considerable growth of it will turn any crop yellow and make it weak and sickly.

Late, clean cultivation of land in cotton, so as to prevent crab grass from making seed, will, in a measure, eradicate it and make cultivation easy the next year. But it soon appears on the land again.

Coce, or Nut Grass. - We have already told how crops are made in spite of this pest. It is never saved for hay, and amounts to little for pasture. It is widespread in parts of Lonisiana, Mississippi, and other states, and is the hardest of all pests to kill. As hogs root after the nuts on the deep roots, small patches may he killed by pasturing it heavily with hogs. Dense sharle with pea vines, velvet beans, etc., weaken it.

Given extra working, as good cotton is grown where this grass grows as where the land is clear of it.

\section{QUESTIONS}

Describe Bermuda grasis. Will it carry much stock on an acre? Is it erer used for hay? Was it ever considered a pest on the farm? Can it be easily killed? What clover should he grown on Bermudia pasture, on clay, and loamy land? What elover would be better on sandy land? Where does carpet grass thrive? Where does Japan clover grow? What are its uses? IIow does Johnson grass generally get into the farms? Is it a good hay grass and is the quality of the hay good? What objection do people have to the hay? IIow can Tohnson grass be killed? Tell something of (ininea grass and Para grass. Are they likely to become valuable in the Lnited States? Would you consider crab grass a pest? What is nut grass? Is it easily killed? 


\section{CHAPTER XXXII}

\section{ORCHARD CROPS}

Intensive and Extensive Farming. - ( )rehards and truck farms require more capital, more skill, higher fertilizing,

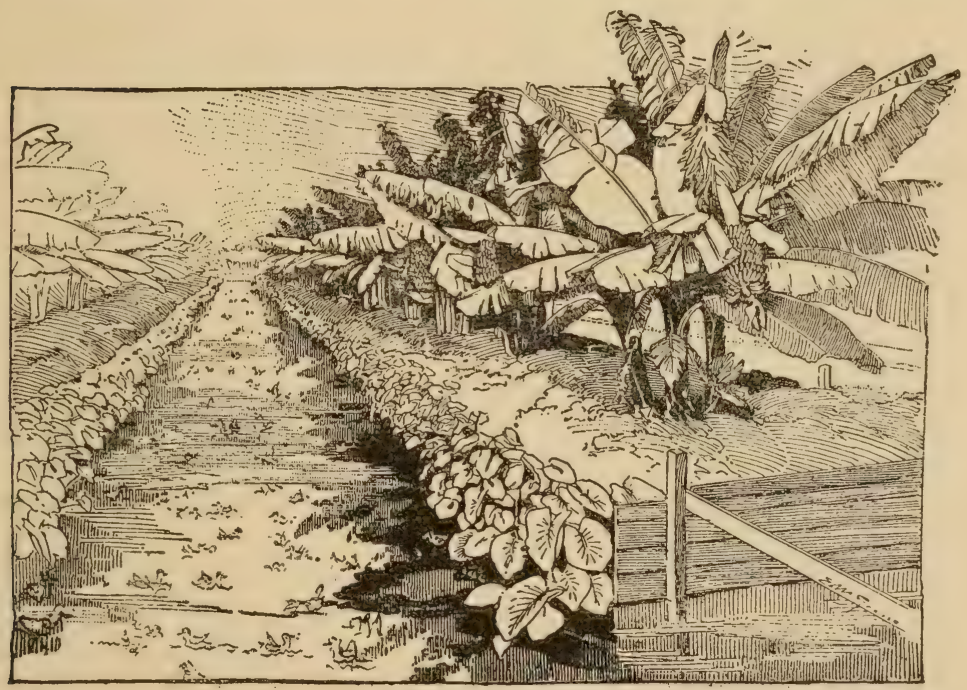

Fig. 78. - Intensive Farming

(Chinese in Hawaii grow hananas and taro on ridges, ducks and fish in canals between ridges.)

and more intensive culture than other lines of agriculture. Sometimes as much as $\$ 1000$ is spent in producing a crop on a single acre, and maybe $\$ 2000$ is expected in returns 
(on the crop. (One such crop is celery. ('abbage and onions may require an expenditure of $\$ 7 ;$ ) to $\$ 100$ an acre, and may bring returns of $\$ 150$ to $\$ 300$ an acre. Among the crops grown on the extensive system may be mentioned wheat, whose average money returns to the acre in the United States are about $\$ 10$, but the average expenditures in making and marketing may be only $\$ 8$ or $\$ 9$. The same business ability and effort neces-

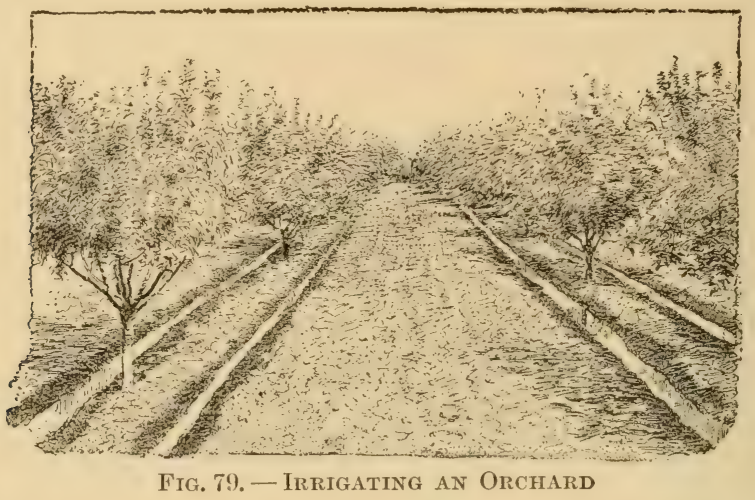

sary to handle 500 acres of wheat would probalbly not be sufficient for two acres of celery or 10 acres of cabbage or onions. In extreme case of extensive farming is pasturing beef cattle on a range where one man can look after thousands of heads of eattle on tens of thousands of acres, each acre bringing small returns-sometimes not more than 10 cents.

Early Truck and Fruit.__ Growing fruits and early vegetalhles in the South for shipment to Northerm markets has grome into a very large husiness. Solir train loads of 
early truck crops are often made up at a single shipping point. The cars are iced and the train is run on a special schedule to get the perishable freight to the market in good conclition. When there is a large amount of such produce to move, the railroads handle it better and get it to the market more quickly than they do small amounts. At

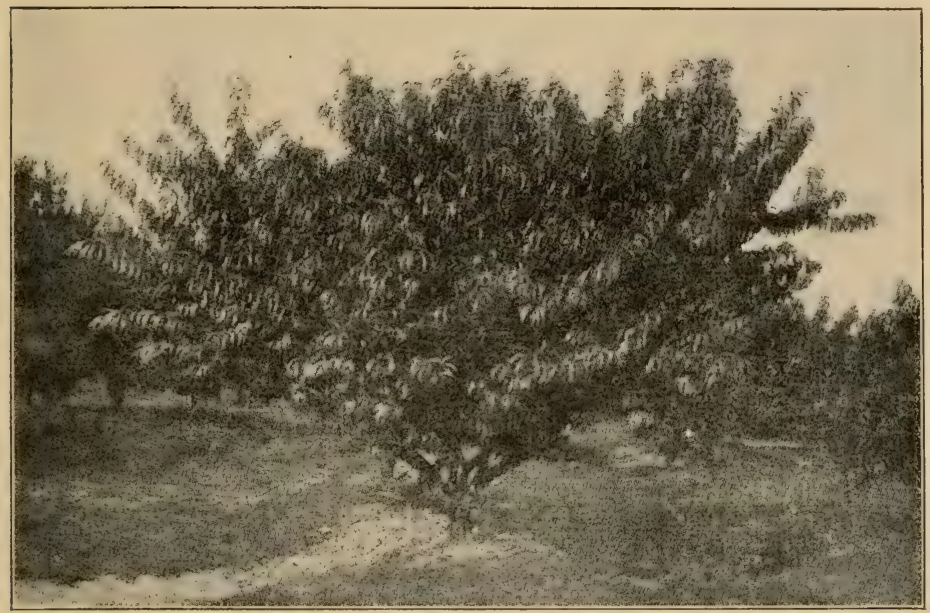

Fig. 80. - Well-trmamed Texas Peach Tree

the same time buyers are attracted to the places of large production, and better prices are offered. As truck farmers have become more and more experienced in making, packing, and shipping produce, ferver losses occur, and the business is becoming more certain of fair profits.

Peaches. - Among the tree fruits grown on a commercial scale in the South, the peach stands at the head of the list. Peaches are not a certain erop; they fail 
to produce fruit perhaps half of the seasons because the fruit buds are killed by cold. The orchards are not expensive to bring into bearing, however, and when a good crop is made, it is generally very profitable. Peaches do not require rich lands.

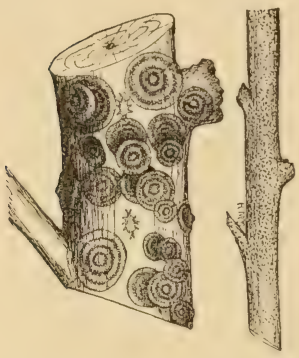
Fig. 81. - S.lN José
SCALE oN PEACH Trees The largest and best orchards in the South are found on well-drained sandy loams that require commercial fertilizer to produce good cotton crops. The land intended for peaches should be well plowed and harrowed. Good budded trees should be planted, preferably in checks eighteen by eighteen feet or even widler apart. The young plant should be trimmed for setting.

Expenses of Orchard. - Good one-year-old budded trees can often be bought in large numbers for five cents each. So a sufficient number of trees for an acre - 108 - would only cost $\$ 5.40$; and preparing the land, fertilizing, and setting the trees should not cost over $\$ 10$ more.

Growing Crops in Orchard. - For the first two or three years the young orchard may grow cotton or Irish potatoes between the rows of trees. Any crop that is well fertilized and cultivated will not hurt the trees. The cultivation of the crop also cultivates the trees. Ileavy crops of peas grown in the orchard may draw too heavily on the moisture supply in late summer. P'eas also breed certain root diseases that in some cases are very destructive to the peach. The bur clover, or crimson clover, makes a fine winter cover-crop for the orchard. These 
crops gather nitrogen and prevent leaching in the winter. and die in the spring before the moisture supply begins to run low.

Cultivation in Dry Sections. - Good clean cultivation at all seasons is best for orchards in dry sections of country.

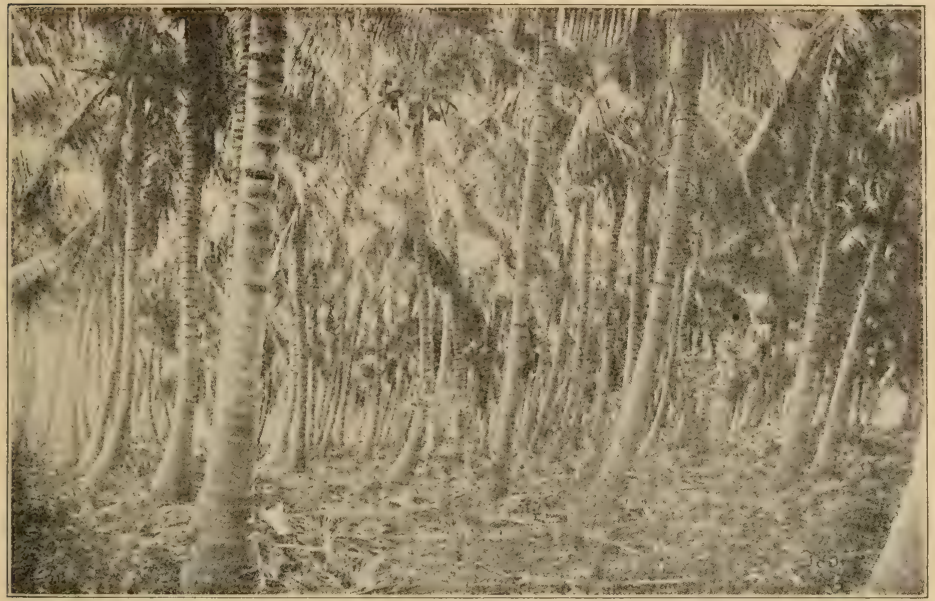

Fig. 82. - Coconnut Plantation, as seen in lilorida, Porto Rico, Hawait, and the Philippines

It is impossible to grow any two crops together without their dividing moisture with each other.

Pruning. - Trees should be so prumed as to force the branches to grow out within from twelve to twenty inches of the ground, and these branches should be pruned each year so as to prevent the tree from growing too tall and to give it a symmetrical shape. Observation and experience will be the best guides in learning how to prune trees. 
Thinning Fruit. - Thimning the fruit on the tree is very imprortant. If a large number of peaches remains on a tree, they will be small and inferior. If some are cut off when small, leaving one every six or eight inches on the limbs, perhaps as many total pounds or bushels of fruit will be made, and the quality will be much better. Pro-

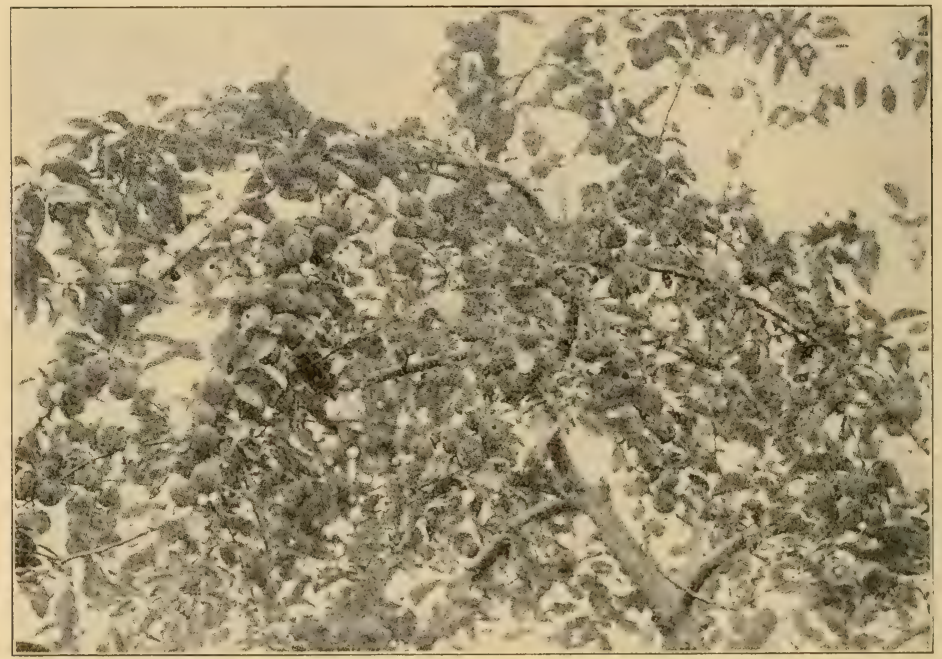

Fig. 83. - Ax APPLE BrANCH

ducing seed is the most exhansting part of any plant's work. If a great many small peaches are maturesl, the strain on the vital energies of the tree will be greater than if fewer large peaches are allowed to come to maturity.

Apples. - Apples are not commercially important in the (rulf and Sonth Atlantic States, except in the highlands of parts of Georgia and the Carolinas, and perhaps on a 
little elevated land ị Alabama. 'The elevated sections of Northern Arkansas grow immense quantities of fine apples. Texas people grow a few fine winter-keeping apples on the lands having an elevation of 2000 feet and above in the western part of the state. The apples grown on the lowlands of the South mature in summer, when the weather is too warm for them to keep. In the higher, more northerly, and cooler sections apples ripen in the

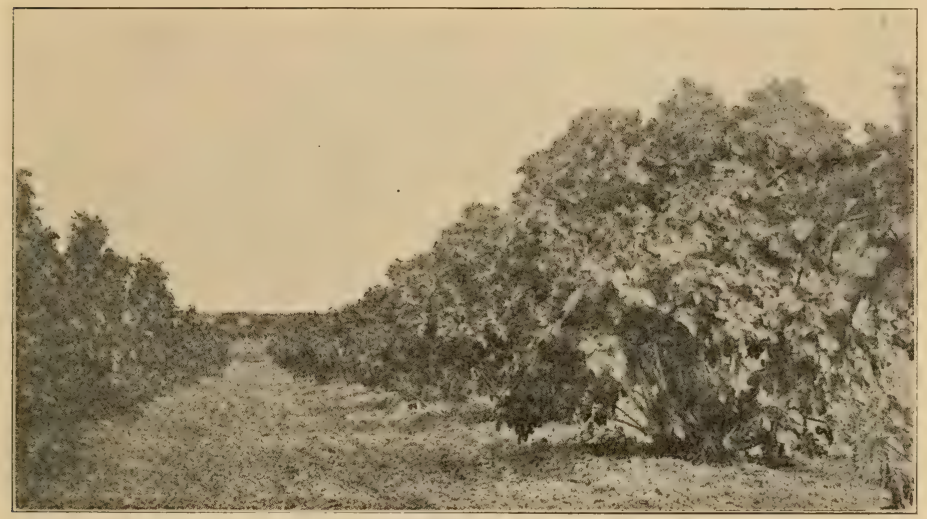

Fig. 84. - Figs at the Thxas Experiment Station

fall, when the weather is cool enough for them to keep over winter. Where apples do well, they are more certain to yield well than peaches, and the trees live longer. Virginia, 'Tennessee, Kentucky, Arkansas, Oklahoma, Missouri, and Kansas all have great possibilities in the way of apple growing.

Figs. - In the United States the fig is one of the best and surest fruits that are grown, for latitudes south of thirtyone and one-half and for a considerable distance north 
of this on the Atlantic coast. They do fairly well as far north as 33 degrees. 'The fig never fails to produce fruit in abundance if it has any wood growth at all. Sometimes in higher latitudes the trees are killed to the ground by a severe frost, but they sprout up from the roots in the spring and make a small crop on the new wood.

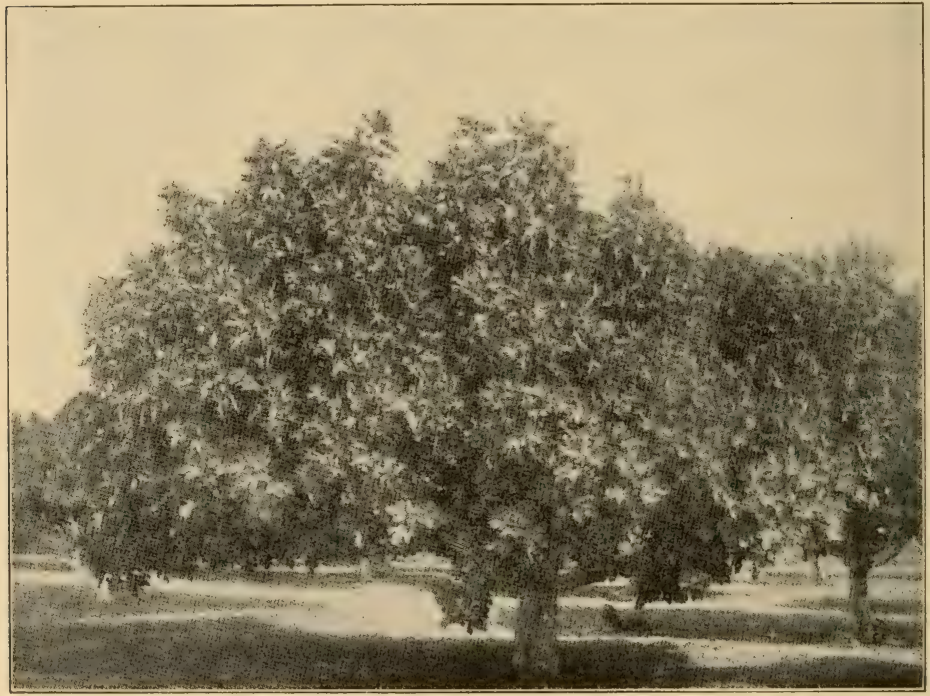

Fig. 85. - Shiyrna Fig Trees, California

The next year they yield abundantly. Along the Gulf Coast, from West Texas to Florida, they are seldom killed by the cold, and the crops are large and very profitable. Some trees along the coast are known to be eighty years old. No fruit tree is easier to start, the fig being propagated either by layering or simple cuttings. hise Figure $23 \mathrm{for}$ proper depth to plant fig cuttings. 
The fig needs rich soil, or soil made rich by fertilizing. ()ften in sections where figs are liable to be killed by a hard freeze, some protection like a house, a fence, or other trees will save their lives. To protect oranges in South Texas or Louisiana, dirt is often piled up around the trunks of the trees. If the cold kills the wood above the bank of dirt, the buds protected sprout out vigorously and make a profitable tree again. Figs might be treated in the same way, and thus more live wood be saved.

About three hundred fig trees are planted to the acre. These commence bearing by the second year, and by the third or fourth year often yield a dollar's worth of fruit to a tree. The fruit is so desirable for preserves that it brings a very high price as compared with most fruits. In South Texas contracts are being made by preserving establishments to take the output of orchards being planted, at three to five cents a pound for the fresh figs.

Pecans. - All fine varieties of pecans now propagated by grafting came originally from sports found in the forests, and many more are surely yet to be discovered in the same way.

The best statistics available place the yield of pecans in Texas at 700 carloads, worth about $\$ 1,500,000$.

The importance of planting only budded trees of good kinds has been referred to. It is recommended that from 25 to 50 trees be planted to the acre. The land should be worked in some erop requiring clean cultivation, like cotton. Pecans come into profitable bearing in from 7 to 10 years, and the crops increase as the trees grow older. An orchard of a fine variety of pecan is very 
profitable, and it will probably last 100 years ol more.

Citrus Fruits. - It is freely maintained that Southwest Texas has soil and climate suitable for growing oranges, lemons, and grape-fruit in quantities to rival the productions of Califor-

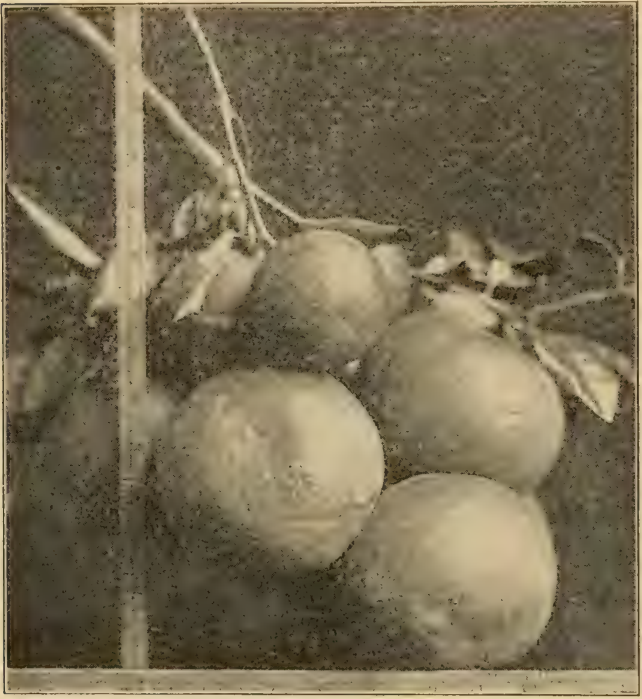

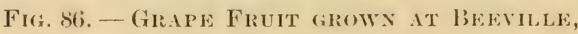
Texas, Branch Experiment Station (Ten pounds on one short limb.) nia and Florida. Fine large trees, loaded with $m$ a $g$ if i c ent fruit, are to be found at various places in South Texas and Louisiana. Many of these trees are so old as to prove that the climate is not too cold for them. Many large orchards are being set in oranges and other eitrus fruits, and there is little doulst but that this will become one of the big industries of the southwest as it is $110 \mathrm{w}$ in the Southeast in Florida.

Satsuma Oranges. - The variety of oranges especially planted in our coast country is the Satsuma, a heary bearer of medium-sized, delicious fruit without seed. It 
is dwarfed by being budded upon a small, hardy tree, or shrub of the orange family, called Citrus trifoliata. This trifoliata can withstand the winter as far north as New York; but its fruit is worthless, and the plant, when not used as orange stock, makes an excellent hedge plant.

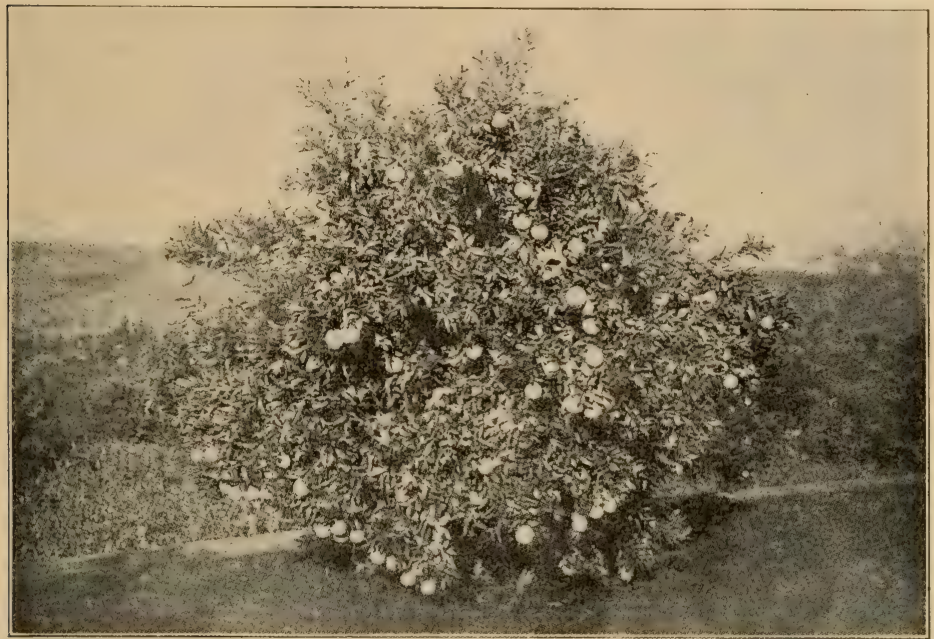

Fig. 87. - Texas Orange Tree

Remember this book can discuss but a few important fruits. Procure a good book on horticulture suited to your section, and get your station bulletins and Department publications.

\section{(QUESTIONS}

Explain the main difference between extonsive and intensive farming. Give an example of very intensive culture. Of extensive culture. Which is more intensive, cotton or corn? Why? Which is more intensive, sweet potatoes or sugar cane? What of the growth 
of fruit and truck raising in the South? What arlvantage does the truck farmer who lives in a community of truck farmers have over one being in the business alone? What fruit is more largely grown than any other in the south? IIow would you start a peach orehard? Ilow expensive is it to start an acre of peaches? Ilow often do jreaches make good (ropss? Are they profitable? What can be done with an orchard when trees are young? Why are peas objected to for growing in orchards? Why would bur clover or vetch be better? Why should you not grow anything in an orchard in a semiarid country? Inow should trees be prumed? What reason is there for thinning fruit on the trees? Why are apples not commercially important in the (iulf states? What are the conditions necessary to grow winter-keeping aplles? What conthern states possess these advantages? Why is apple-growing a good business where conditions are favorable? Tell what you know of the fig. IIow profitahle may fig-raising become? What advantages have figs orer all other orchard crops? What suggestion is made to save figs from winter-killing to some extent?

Where in the United States are most of the oranges, lemons, and citrus fruits grown? Where are the citrus fruits beginning to be planted? Tell about the Satsuma orange and how it is propagated. What part of the southwest is destined to becone a great citrusgrowing country? T'ell something of pecan growing.

Suggestion. - Practice budling pecans, oranges, etc. Cut off hickory limbs and top's in winter. Send for careful directions for budling peans in these next summer. It would be a great accomplishment if you conld make nearly worthless hickories hear fine paper-shell pecans.

Plant ont a good number of fig cuttings. Start a small orchard, freferably on the sonth side of buldings, fences, or other trees. Manure trees highly, protect them from cold if necessary hy temporary wind-hreaks. and you will som see what a profitable crop it is. 


\section{CHAP'TER XXXII}

\section{TRUCK CROPS}

Irish Potatoes. - Irish potatoes are largely grown for Northern markets. They need a good rich, warm soil, as well as rapid working and artificial water supply where it

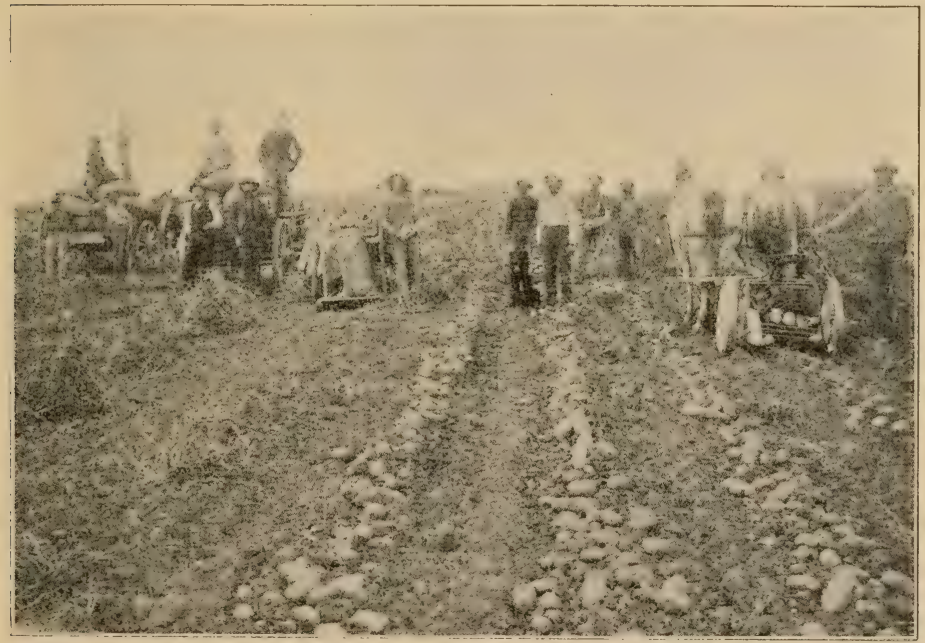

Fig. 88. - Harvesting Irish Potatofs

is feasible to provide it. On a good sandy loam soil, potatoes should make their largest yields of good smooth tulners. Seed should be eut in rather large pieces, as has 
already been explainerl, so as to plant about twelve bushels of seed to an acre.

Fertilizers. - About 800 pounds of fertilizer, containing 200 pounds cotton-seed meal, 500 acid phosphate, and 100 pounds nitrate of soda will generally assure a good (crop). This fertilizer should be put out and the land to he planted bedded on it, or it should be sprinkled in the furrow with the seed potatoes. Very few soils are dry and warm enough in the humid part of the South to justify planting on a level.

Enemies. - The Colorado potato beetle is sure to attack the crop. Weak solutions of P'aris green will easily kill this pest. When blight attacks the leaves, spraying with Bordeaux mixture is desirable. To prevent scabby potatoes from being produced, the seed is often soaked in a solution of formalin, one part of formalin to 300 to 400 of water, to kill any seab spores, or seeds of fungi, that may be on the seed.

Yield and Profit. - A fairly good yield of potatoes is 100 to 150 bushels to the acre. When they bring 75 cents to $\$ 1$ a bushel at the shipping station, good profits are usually marle. Sometimes the markets are too low to ship at a profit. In that case, if the potatoes could be put in cold storage and kept a month or more, a good demand could be harl at home. By midsummer all Sonthern potatoes are out of the market. and Northern potatoes are being shipped South.

Second Crop. - Crood erops of sweet potatoes, corm, cottom, ete., ian be grown on the Irish potato land after the jotatoes are dug, saly in June. In growing a fall erop of 
potatoes, saving moisture enough and preserving the seed are the greatest difficulties. 'The small potatoes of the first crop are spread out in a good shade and partially covered with straw or leaves. 'They are allowed to lie till splouts appear, and are generally planted whole. Cutting will make them come up quicker, but they are liable to rot when cut. The fall-grown ('lol) makes gool seed the following spring.

Hotbeds. - A hotbed is made by mixing stable manure, cottun seod, etc., and surrounding this with a suitable

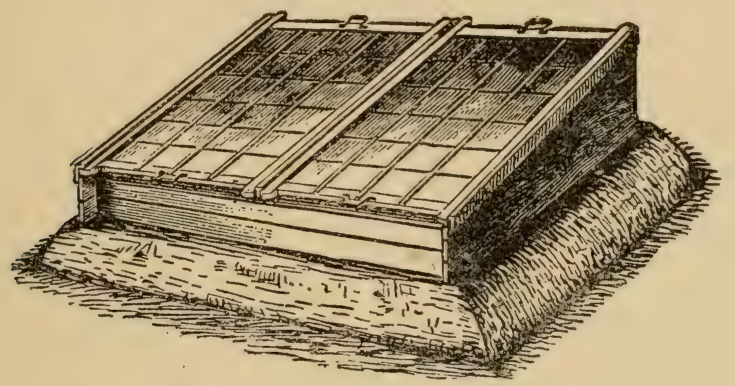

Fig. 89. - Sirale Нotbed

frame and covering with glass as shown in Figure 89. The rotting manure produces heat, and the sum's rays enter through the glass, which at the same time prevents the escape of heat from the hed. Some hotberls have flues underneath and are heated by fires. By cither plan, plenty of warmth can be controlled to grow any plant.

Tomatoes. - Tomatoes, eggplant, peppers, etc., are started in January in the (xulf States. The tomato plants are taken out of the hotbed about February and trans- 
planted into a cold-frame. A cold-frame has no heating manure, and it is covered with chotis. The object is to harden the plant as much as possible and at the sanne time protect it and keep it growing. When all dangerer of frost is over, the plants are taken from the cold-frames

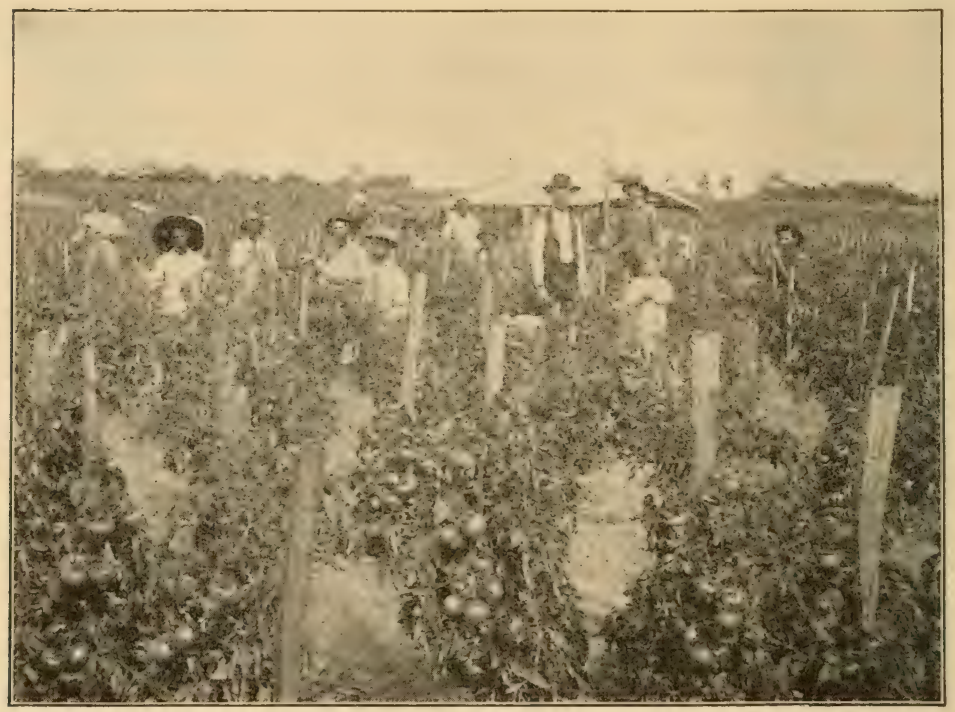

Fig. 90. - Gathering 'Tomators

and transplanted to a field in checks about three by four feet. The plants are kept tied up to stakes, as shown in Figure 90. All the suckers are kept pinched off the plants, and when they have grown about three feet high, and have set a good erop of fruit, they are topped. 'The' object is to force them to produce a gool crop of fruit early. If one wishes tomatoes for home use or for "all- 
ning, it would be better to let the plants grow longer and branch out and continue to bear.

Enemies. - The cotton boll worm is hard on the tomato, but generally a good early crop can be gathered before the worm gets very abundant. Tomato blight is a muchdreaded disease. The crop should be planted on a fresh piece of ground each year.

Yield. - Tomatoes often produce 500 bushels to the acre, and the crop is usually profitable. It does not re-

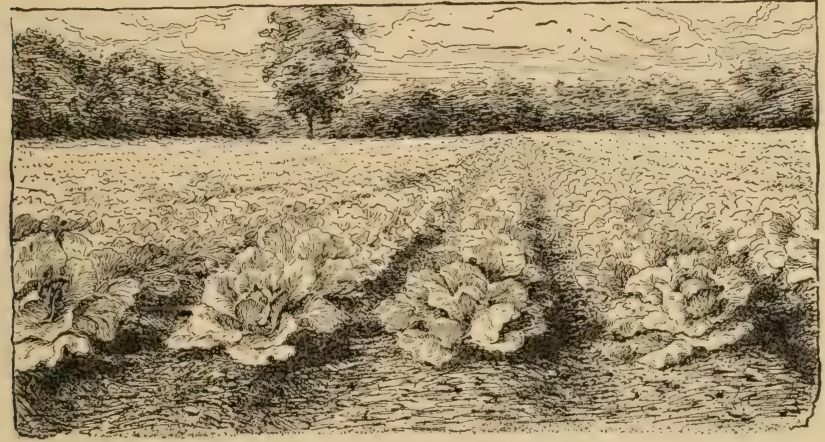

Fig. 91. - Cabbage Field

quire such high fertilizing as cabbage and potatoes. Three or four hundred pounds of fertilizer to the acre is ample on ordinary sandy loam soil.

The largest tomato-growing places in the South are Jacksonville, Texas, and Crystal Springs, Mississippi.

Cabbage. - Early cabbage are sometimes started like tomatoes in hotheds and cold-frames. They are set out in the field earlier than tomatoes, being set in three-foot rows, at the rate of 8000 plants to the acre. Farther 
sonth they are often planted in open ground in September or October and transplanted from November to February in the fields where they are to grow. Cabbages need rich land or plenty of fertilizer or both combined. A ton of fertilizer is often used to the acre. They need good cultivation. In the different sections of the Gulf States, cutting and shipping take place from March until June. I fairly good crop is 100 crates, weighing about 120 pounds each, but often twice this amount is producerl. One dollar a hundred pounds at shipping station is a profitable price. The crop often brings much more. When prices are too low for profit, cabbage can be liept in cold storage as recommended for Irish potatoes.

Every ice factory should have a cold room to store crops like this. A large and profitable business conld easily be built up in most localities in storing perishable vegetables of this kind.

Onions. - Onion growing is a large and lucrative business, especially in Southwest Texas. Fields are frequently as high as 500 to 800 bushels to the arre on rich, well-fertilized and irrigated lands. Probably 300 bushels is nearer the average. The onion seed are planted on beds in September and October in little rows about three inches apart. From I ecember to February they are transplinted to the fields. The plants are placed in rows about 15 to 18 inches apart, and set as close as four inches in the rows. It has been estimated to cost $\$ 30$ an acre to set onions in this way.

The crop is generally realy to harvest in May, and is shipped in sacks to the Northern markets. The onion 
crop seldom nets the grower less than 7 i) cents a bushel and frequently over a dollar.

There are many other profitable market crops, but they camnot be discussed in this book without making it too long. Peas, beans, canliflower, lettuce, radish, pepper's, asparagus, celery, melons, and numerous other crops are s'rown for the Northern market profitahly. Throughout the Plains comntry partienlarly, as fine cantaloupes and watermelons as ever grew can be raiser in wreatest abundince. Melons have heen considered for sugar production on the Plains, but the sugar beet also thrives there. Iour experiment station will refer you to good books and bullelins that will give you the details of the culture and hantling of all of them.

\section{QUESTIONS}

What sort of land is best for raising Irish potatoes? Do they med much fertilizer? What fertilizer mixture is suggested? Why are potatoes not often planted on a level in the South? What insect and what disease attack potatoes? What are the remedies for these troubles? IIow can scabby potatoes be prevented? Tell what the rield and value of potatoes should be. What suggestion is made when the Northern markets are low? What crops can be made on the Irish potato land after the potatoes are gathererl? II ow are fall Irish potatoes grown? IIow are tomatoes planted? I)escribe a hotberl. What is a cold-frame? IIow are tomatoes worked, staked, and trimmed? Do they neerl heary fertilizing? What insect troulles the tomato? What fungous disease does the tomato suffer from? What is a fair vield of tomatoes? Where are the largest shipping points in the Sunthern States for tomatoes? Iow are cabloages started in different sections? When are they cut and shipped? I) they need heary fertilizing? What is a good yield of cabbage and what is a lrofitable price? What can be done with cabbage if Northern markets set low? Tell something of onion growing. What is a good yield? What prices are received? Do they need high fertilizing? 


\section{('HAPTER XXXIY}

\section{THE FEEDING OF ANIMALS}

Animals made of Plants. - You learnerl in the first part of this book that animals must be comprosed of the same chemical elements as plants, becanse they are built up by eating plants. If all the blood, lean meat, hain, tendons, membranes, skin, hair, hoofs, and horns of animals conld be separated from the rest of the borly and dried, they would contain sixteen per cent of nitrogen. The cheese, or curd of milk, when dry, also contains sixteen per 'ent of nitrogen. To animal can live unless the substances in its food furnish nitrogen. Fortumately, most natural foods contain this element in small or large amounts. The substances in food that contain nitrogen we call protein, and, like the nitrogenous pruts of the animal body, protein contains sixteen per cent of nitrogen.

Protein Feeds. - The white of an egg is pure protein. Peas, beans, peavine hay, alfalfa hay, etc., are rich in protein, because, as you remember, these plants feed on the nitrogen of the air, and they make this nitrogen into the compound alled protein. ('otton seed and cottonseed meal are very rich in protein. No animal can give a good supply of milk withont plenty of protein in its food.

Fat-making Feeds. - Animals must also have material to make fat in their borlies, and to make the butter fat of 
milk. Fat, or oil, in foorl, such as cotton-seed oil, wam do this, because all fats are made of three things-carbon, hydrogen, and oxygen - whether they are vegetable fats or animal fats. Protein can build fat, because it contains carbon, hyllogen, and oxygen along with its nitrogen, lout it is too expensive to feerl so much of it. The sugar, starch, gums, and woody parts of plants are also made of cartonn, hydrogen, and oxygen, and can build fat in the body. Com is about tro-thirels starch, and you know how it puts fat on hogs.

Heat and Force-making Feeds. - But most of the foor eaten by animals is nsed to keep their hodies warm and to produce force and work. It is hurned up to keep the machine hot and to keep it rumning. Sugar, stareh, grums, fiber, or wooly matter in the foods are used for this purpose. These substances taken together are caller carbo-hydrates. Fats in food can also be hurned to keep' up heat and produce energy or work. You have heard of the Esquimaux (linking fish oil to keep) warm. Protein can also be bumerl to make heat and force, but it is usually too expensive to be fed for this purpose. So we see protein can do its own special work, and can also take the place of fats and carbo-hydrates if necessary.

Ash and Water. - The ash of plants contains the materials for making hones. But as almost all feeds contain plenty of ash, we need not further consider it. All feeds also contain some water, but this is not necessary, since animals can get plenty of water from the creek. So can animals get plenty of water in feerls sometimes. In the Hawaiian Islands thousands of cattle never drink any 
water. They graze on high mountain land where there is mulh rain, but the rain sinks so fast in the volcanic soil that none accumulates on the surface. The grass is quite green and affords plenty of water.

Digestibility. - Of comse, feed stuff, in order to murish animals, must be digested. Only from one-half to twothirds of hay is generally digested, and from three-fomths to seven-eighths of grains and meals. An animal of a given size needs a certain amount of digestible protein, arbo-hydrates, and fiets to aceomplish a particular result. These are called nutrients.

Amounts of Digestible Nutrients Needed.-A milk cow, a fattening steer, or a hard-worked horse may be said to need each day about two pounds of digestible protein, about twelve or thirteen pounds of digestible carbohyclrates, and about a half pound of digestible fats. More protein, say up to three pounds a day, certainly would do no harm, if not too expensive. Of course, large animals or those giving large quantities of milk, need more, while small animals, or those giving less milk, require less. Animals not expected to work, gain in weight, or give milk can get along on one-fonth this amount of protein, and much less of the other nutrients.

Proportions of Coarse Feed. - Cattle will generally utilize food most economically, if given about two-thirds, by dry weight, of coarse. bulky foods, such as hay and forlder, and one-third concentrated feed, or concentrutes. such as cotton seed, corn meal, cotton-seed meal, bran, cte. (attle on full feer will need about twenty-five to thirty pounds of dry feed a dity. IIorses, when heavily worked, 
should have at least half their food by dry weight of concentrates, and the other half of roughage, or roughuess, and should have about twenty to twenty-five pounds of dry feed a day. All animals will eat larger proportions of concentrated feed, if allowed to have it. Sheep, in fattening, seem to do best on about lialf concentrated

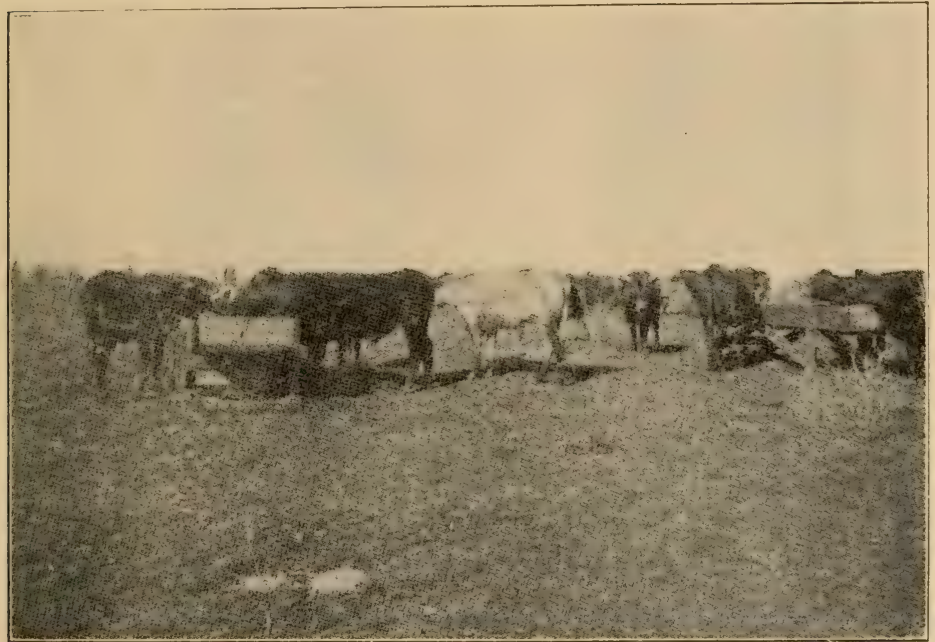

Fig. 92. - Southwest Texas Stefers being fattened un Cactus AND CotTon-seed MeAL

and the other half rough feerl. IIogs, when fattening rapidly, eat still more concentraterl feed than sheep and horses. Young animals need more protein than older ones, because they must build nip lean meat and tissue. They also eat more in proportion to live weight than older animals.

Calculating Nutrients. - Chemists analyze all the fom stuffs and find out how much protein, carbo-hydrates, and 
fats each contains. Ictual trials have been made of all of them to see how digestible they are when eaten by different animals. If a certain feed, for instance, has 14 per cent of protein, and 75 per cent of this is digestible, then we have .75 ) of .14 , equals .105 (1t per cent multiplied by 75 per cent, decimally, gives 10.5 per cent of digestible protein in the feed). If you want to feed your milk cow 5 pounds of this feed a day, then you will give her 5 times .105, or .525, pound of digestible protein. This will be about $\frac{1}{4}$ of what protein she needs, but if she has a good pasture to rum in, she may there get the rest of what she needs. But if the pasture is not good, suppose you give her $t$ pounds of cotton-seed meal. It will contain about 40 per cent protein, and about 8j per cent of this will be digestible. Eighty-five per cent of 40 per (ent will be $3 t$ per cent. Then $t$ prounds times 34 per' cent $(.3+$ pound) will make 1.36 pounds. This added to what the other feed contained would be nearly 2 pounds. The pasture would have to be very poor, if this much feed did not give the cow more than enough digestible protein. l'oor pastures, dry stalk fields, rough woods, ranges, etc., may easily supply the carbo-hydrates necessary.

Nitrogen-free Extract and Crude Fiber.-In analyzing feeds for carbo-hydrates, the chemist divides these into two groups, because one group is usually more digestible than the other. The sugar, starch, grmms. ete, he puts into one group, which he calls nitrogen fire ritract. The tibrous, wooly part of the feed he puts into another group, which he calls crute fiber. A feed like hay or cotton- 
seer hulls or straw contains much crude fiber and is always bulky, and is not very digestible. A feed containing much starch, like corn and sweet potatoes, or sugar, like sugar heets, is very digestible, and hence more valuable in proportion to dry weight than hay, hulls, and straw. Nearly all feeds that have not gone through some manufacturing process contain nitrogen-free extract and crude fiber, as well as protein, fat, and ash.

Calculations. - If a grass hay contains to per cent nitrogen-free extract, and 65 per cent of this is ligestible, then the hay contains 26 per cent digestible nitrogen-free extract. If the same batch of hay contains 25 per cent crucle fiber, and 40 per cent of this is digestible, then it will contain 10 yer cent digestible crucle fiber. After crude fiber and nitrogen-free extract are both digested, they are counted as having equal value. 'Therefore, we arld the two digestible amounts together, 20 per cent nitrogen-free extract and 10 per cent crude fiber, and call them carbo-hydrates, and we have 36 per cent digestible rmbo-hydrates in this hay. If you fel a cow 20 pounds of such hay a day, you would give her 20 times . 36 pound of digestible carbo-hychates, or 7.20 pounds in this feed alone. If you have never had money enough to take any interest in percentage and decimals, you have now found that knowledge of this kind is needed in order to calculate rations for farm animals.

If certain seed has 19 per cent of fat (oil), and 75 per cent of this oil is digestible, then this seed contains 14.25 ler cent digestible fats. If you feed 5 pounds a day to a (๓) you give her in the seed alone about .71 of a pound 
of digestible fat. If you have reviewed your decimals and pereentage, you now have all the mathematics you need to calculate suitable rations for live stock from the following tables, which contain the digestible nutrienti in 100 pounds of rach of our different common feed stuffs. In the table the caleulations for digestible nutrients are made for us. By means of the last column in the table you can always calculate the fertilizing value of the foor fed animals, and can rosely estimate the value of manme madte. Wheat hran, cotton-seed meal, and other rich feeds produce enough manure to go far toward paying for the feeds.

\section{TABLE No, 1}

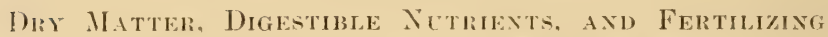
VALIE IN 100 pounds of FreD STUFFs

\begin{tabular}{|c|c|c|c|c|c|c|}
\hline NAME OF FEED & & $\begin{array}{c}\text { DRY } \\
\text { MATTER }\end{array}$ & Proteix & $\begin{array}{l}\text { CARBO- } \\
\text { HORATES }\end{array}$ & $\mathrm{FAT}$ & $\begin{array}{l}\text { FERTILIZIN } \\
\text { VALUE IN } \\
100 \text { LBS. OE } \\
\text { FEED }\end{array}$ \\
\hline GREEN FORAGE- & - & & & & & Cents \\
\hline Pasture grass. & .. & 20.0 & 2.50 & 10.20 & 0.50 & 10 \\
\hline Corn fodder . & .. & 20.7 & 1.10 & 12.08 & 0.37 & $S_{1}^{3}$ \\
\hline Bermuda grass & . & 33.0 & 2.60 & 14.80 & 0.30 & 10 \\
\hline Johnson grass & - & 34.0 & 2.40 & 16.50 & 0.50 & 10 \\
\hline Japan clover. & . . & 30.0 & 2.70 & 14.40 & 0.60 & 13 \\
\hline Craio grass . . & .. & 33.0 & 1.90 & $1+.00$ & 0.60 & 9 \\
\hline Sorghrm . & . $\quad$. & 20.6 & 0.60 & 12.20 & 0.40 & 5 \\
\hline Alfalfa. & .. & 28.2 & 3.90 & 12.70 & 1.00 & 16 \\
\hline Cowpea. . & . . & 20.7 & 1.80 & 8.70 & 0.20 & 1:) \\
\hline Soy bean . & .. & 24.9 & 3.20 & 2.2 .00 & 1.00 & 16 \\
\hline Oat fodrter. & . $\quad$. & 37.8 & 2.69 & 22.66 & 1.04 & 13 \\
\hline Rye forder . & .. & 23.4 & 2.05 & 14.11 & 0.44 & 10 \\
\hline Barley fodder. & .. & 21.0 & 1.90 & 10.20 & 0.40 & 12 \\
\hline
\end{tabular}


Dry Matter, Digestible Nutrients, and Fertilizing; Value in 100 Pounds of Feed Stufrs - Continued

\begin{tabular}{|c|c|c|c|c|c|}
\hline NaMe of FEed & $\begin{array}{c}\text { DRy } \\
\text { Matter }\end{array}$ & Protein & $\begin{array}{l}\text { Caribo- } \\
\text { HYDR.ATES }\end{array}$ & $F_{\Lambda T}$ & $\begin{array}{l}\text { FERTILIZING; } \\
\text { VALUE IN } \\
\text { 100 LBS, OF } \\
\text { FEED }\end{array}$ \\
\hline \multicolumn{6}{|l|}{$\begin{array}{l}\text { GreEN ForAGE- } \\
\text { (C'ont.) }\end{array}$} \\
\hline Wheat fodder & 36.0 & 2.80 & 18.00 & 0.90 & 11 \\
\hline Orchard grass & 27.0 & 1.91 & 15.91 & 0.58 & 11 \\
\hline $\begin{array}{l}\text { Red-top grass. } \\
\text { Kentucky blue }\end{array}$ & 34.7 & 2.06 & 21.24 & 0.58 & 11 \\
\hline grass . . . & 34.9 & 3.01 & 19.83 & 0.83 & \\
\hline Teosinte. . & 25.0 & 2.40 & 13.50 & 0.20 & 11 \\
\hline Red clover. . & 29.2 & 3.07 & 14.82 & 0.69 & 14 \\
\hline Bur clover. . & 25.0 & 2.60 & 17.00 & 0.50 & 12 \\
\hline Crimson clover . & 19.1 & 2.40 & 9.10 & 0.50 & 11 \\
\hline \multicolumn{6}{|l|}{ SILAgE FROM - } \\
\hline Sorghum . . & 20.9 & 0.60 & 14.90 & 0.20 & \\
\hline Corn . . . . & 20.9 & 0.56 & 11.79 & 0.65 & 9 \\
\hline \multicolumn{6}{|l|}{ HAY FROM -- } \\
\hline Bermuda grass. & 86.0 & 6.90 & 39.00 & 0.80 & 30 \\
\hline Jchnson grass & 85.7 & 6.00 & 41.40 & 1.20 & 30 \\
\hline Alfalfa . . . & 91.6 & 10.58 & 37.33 & 1.38 & 66 \\
\hline Cowpea . . . & 89.3 & 10.80 & 38.60 & 1.10 & 60 \\
\hline Hairy vetch . & 83.3 & 14.60 & 30.60 & 2.30 & 70 \\
\hline Red clover. . & 90.3 & 6.58 & 35.35 & 1.66 & 58 \\
\hline Peanut . . . & 92.4 & 6.70 & 42.10 & 3.40 & 60 \\
\hline Bur clover . . & 83.3 & 8.80 & 36.50 & 0.50 & 48 \\
\hline Crimson clover . & 91.4 & 10.49 & 38.13 & 1.29 & 60 \\
\hline Crab grass. . & 86.0 & 4.30 & 36.40 & 1.50 & 25 \\
\hline Red-top grass . . & 91.1 & 4.82 & 46.83 & 0.95 & 30 \\
\hline Hungarian grass & 92.3 & 4.50 & 51.67 & 1.34 & 33 \\
\hline
\end{tabular}


Dry Matter, Digestible Nutrients, and Fertilizixg Value in 100 Pounds of Feed Stuffs - Continued

\begin{tabular}{|c|c|c|c|c|c|}
\hline NAME of Fenu & $\begin{array}{c}\text { Dr:Y } \\
\text { Matter }\end{array}$ & Próreix & $\begin{array}{l}\text { C'ARBO- } \\
\text { HYDRATES }\end{array}$ & FAx & $\begin{array}{l}\text { FERTHLZINGi } \\
\text { VALCE IN } \\
\text { 100 LHS, OF } \\
\text { FEED }\end{array}$ \\
\hline HAY FROM (Cont.) - & & & & & Cents \\
\hline Orchard grass & 90.1 & 4.78 & 41.99 & 1.40 & 30 \\
\hline Tinnothy grass . . & 86.8 & 2.89 & 43.72 & 1.43 & 25 \\
\hline Kentucky blue grass & 78.8 & 4.76 & 37.33 & 1.95 & 26 \\
\hline Japan clover . . . & 86.0 & 7.80 & 41.40 & 1.80 & 50 \\
\hline Shredded corn stover & 80.0 & 2.30 & 43.20 & 0.90 & 20 \\
\hline Corn blades (fodder) & 80.0 & 4.00 & 40.80 & 0.60 & 35 \\
\hline Corn shucks . . . & S0.0 & 1.30 & 49.90 & 0.30 & 20 \\
\hline Cotton-seed hulls & 88.9 & 0.30 & 33.10 & 1.70 & 20 \\
\hline Wheat straw . . . & 90.4 & 0.40 & 36.30 & 0.40 & 14 \\
\hline Oat straw . . . & 90.8 & 1.20 & 38.60 & 0.80 & 21 \\
\hline Rye straw : . . & 92.9 & 0.60 & 40.60 & 0.40 & 16 \\
\hline Barley straw . . . & 85.8 & 0.70 & 41.20 & 0.60 & 29 \\
\hline \multicolumn{6}{|l|}{ Roots And Tubers - } \\
\hline Sweet Potato . . & 28.9 & 1.00 & 22.50 & - & \\
\hline Irish Potato . . . & 21.7 & 0.90 & 16.30 & 0.10 & - \\
\hline Beets . . . . . & 13.0 & 1.21 & 8.84 & - & . \\
\hline Turnips. . . . . & 9.5 & 0.81 & 6.46 & 0.11 & \\
\hline Rutabagas . . . & 11.4 & $0.8 S$ & 7.74 & 0.11 & 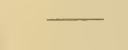 \\
\hline $\begin{array}{l}\text { Artichoke (Jerusa- } \\
\text { lem) } \cdot \text {. . . }\end{array}$ & 20.0 & 2.00 & 16.80 & 0.20 & \\
\hline \multicolumn{6}{|l|}{$\begin{array}{l}\text { GRAINS AND UTHER } \\
\text { SEEDS- }\end{array}$} \\
\hline Cotton seed . . . & 89.7 & 12.5 & 30.0 & 17.3 & 75 \\
\hline Cotton-seed meal & 91.8 & 37.2 & 16.9 & 12.2 & 150 \\
\hline Cotton-seed hulls . & 88.9 & 0.5 & 33.1 & 1.71 & 25 \\
\hline Corn, field . . . . & 89.1 & 7.9 & 86.7 & 4.3 & 33 \\
\hline Corn and cob meal. & 84.9 & 4.4 & 60.0 & 2.9 & 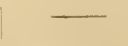 \\
\hline
\end{tabular}


Dry Mlatter, Digiestible Nuthients, and Ferthlizing Value in 100 Pounds of Feed Stuffs - Continued

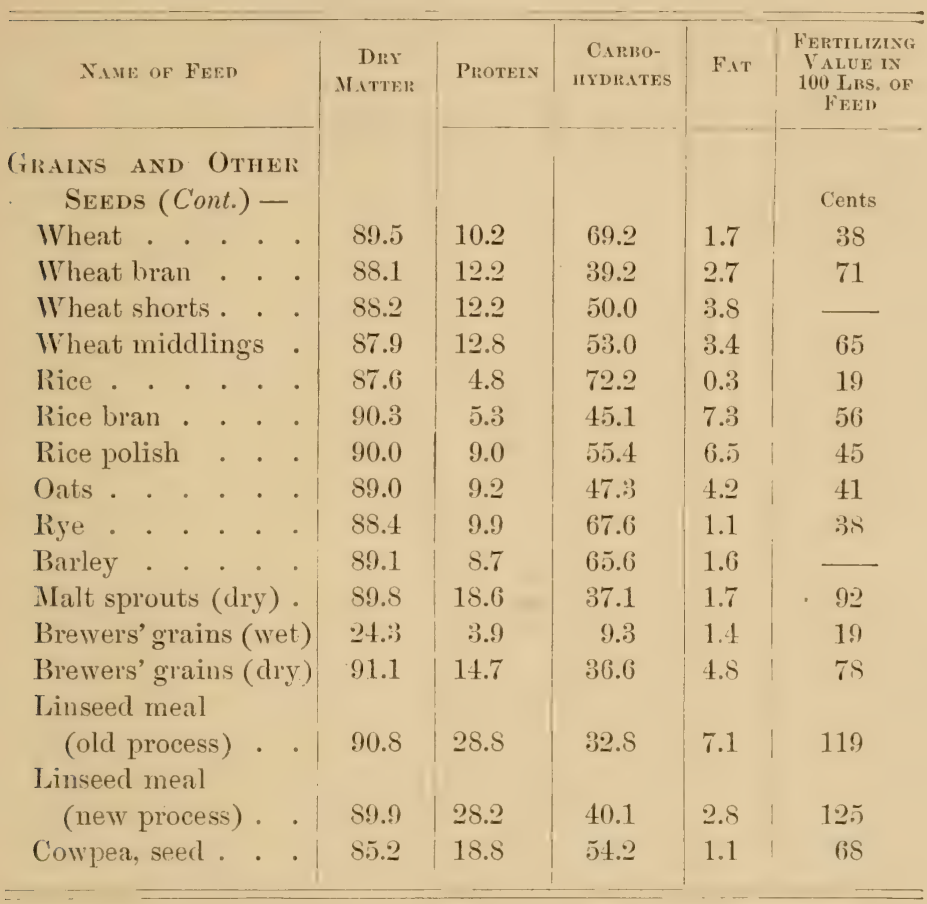




\section{CHAPTER XXXV}

\section{THE MAKING OF A RATION}

Making up Rations. - Suppose you wish a day's feed for a horse of good size that is doing heavy work, and you have oats, peavine hay, and Bermuda hay. Ten pounds of grain and 7 pounds each of the two hays would give $2 t$ pounds of dry, or nearly dry, feerl, and not far from half of it will be grain. Let us make the alculation and fincl out if this food will afford the right amounts of nutrients. You see from Table No. 1 what amounts of digestible protein, carbo-hydrates, and fats 100 pomds of oats contain. You are to use 10 pounds of oats. Hence 10 pounds will contain 10 per cent of all that 100 pounds contain. Make a little table like Table No. 2 below. Find 10 per' cent of the protein in the 100 pounds of oats, and put down in the column headed "Protein." Do the same for" the carbo-hydrates and fats. You are to feed 7 per cent of 100 pounds of each of the hays. Perform the same operations for these. Then add each column.

By this method you get the total of each nutrient. This is perhaps near enough the right amounts of nutrients for all practical purposes. If, instead of ten pounds of oats, six pounds of oats and four pounds of corn were given, we should have almost exactly the standard amounts of nutrients first named for a heavily worked 
horse, a milk cow, and a fattening steer. You should not forget that a small horse, especially if doing light work, will not need so much feed.

Fats Strong Feeds. - You have learned that fat performs the same work in the animal body that is clone by carbohydrates. But the fat is stronger. I pound of digested fat will produce as much fat in the body and make as much heat and energy as two and a quarter pounds of digested carbo-hycliates.

\section{TABLE No. 2}

\begin{tabular}{|c|c|c|c|}
\hline & Protein & C.ABB-HYMRATES & $\mathrm{F}_{\Lambda \mathrm{T}}$ \\
\hline 'Teu pounds of oats contain & .92 & $4.7: 3$ & .42 \\
\hline $\begin{array}{l}\text { Seven pounds cowpea hay } \\
\text { contain }\end{array}$ & .756 & 2.70 & .077 \\
\hline $\begin{array}{l}\text { Seven pounds Bermuda hay } \\
\text { contain }\end{array}$ & .48 .3 & $2.7: 3$ & .056 \\
\hline Total & 2.159 & 10.16 & .553 \\
\hline
\end{tabular}

Nutritive Ratio. - We hear a good deal of the mutritive ratio of feeds. That means the proportion of digestible protein in a feed stuff or in a ration to the digestible carbo-hydrates and fats combined. Multiply the total fat, .55:3 pounds, in the ration above, as shown in Table No. 2, hy 2.25; add the product to the total carbo-hydrates, 10.16, and this gives the carbo-hydrates and fats combined. Then we have 2.159 pounds protein to $11.40 t$ pounds of carbo-hydrates and fats. Divide both amounts by the amount of protein, and we have 1 to 5.2, approximately. 
Balanced Ration. - A balanced ration is one in which the proportion of protein to carbo-hydrates and fats is about right for best results. One to five and two-tenthis is generally considered well balanced. Take the single feed, corn, in Table No. 1. It has 66.7 pounds digestible carbo-hydrates in 100 pounds; also 4.3 pounds fat, which, multiplied by 2.25, gives 9.675. Add this to 67.7, and we have 77.375. Divide by the protein, 7.9, and we have a ratio of 1 to 9.8. This is too wide for most purposes. That means that corn would not give best results as the entire feed of an animal.

Make the same sort of calculation for cotton-seed meal, and it will show about 1 to 1.2 , which is very narrow. Cotton-seed meal would never do as the entire feed for cattle. If cattle run on dry pastures or stalk fields and gather coarse food enough to make the necessary roughage and furnish needer carbo-hydrates somewhat to balance the cotton-seed meal, then it may be fed alone with good results by properly limiting the quantity. If cottonseed meal and corn meal are fed together, they balance each other, but all concentrater feerls must be limited in the quantity fed. A mixture of these two feeds and some hay or cotton-seed hulls for hulky feed may be fed with good results.

\section{Hogs and Sheep eat much Concentrated Food. - IIog's} eat from two to three times as much digestible food in proportion to live weight as cattle. The food for hogs must be more concentrated, but the proportion, or balance, should be about the same. Sheep eat more digestible food in proportion to live weight than cattle, and their 
food should have a larger proportion of concentrates. The balance, or proportions, should be about the same as for other animals.

Suitable Rations. - As suitable daily rations for a milk cow the following are suggested to be divided and given in two feeds :- -

No. 1. $\left\{\begin{array}{r}8 \text { lbs. (or qts.) cotton seed. } \\ 10 \text { lbs. prairie hay. } \\ 8 \text { lbs. cotton-seed hulls. } \\ 2 \text { lbs. }(3 \text { pts.) rice bran. }\end{array}\right.$
No. 2. $\left\{\begin{array}{r}4 \text { lbs. }(4 \text { pts. }) \text { cotton-seed meal. } \\ 5 \text { lbs. }(7 \text { pts. }) \text { rice bran. } \\ 20 \text { lbs. cotton-seed hulls, or sorghum hay. }\end{array}\right.$
No. 3. $\left\{\begin{array}{r}2 \text { lbs. cotton-seed meal. } \\ 5 \text { lbs. cotton seed. } \\ 3 \text { lbs. wheat bran. } \\ 16 \text { lbs. Johnson grass, sorghum, crab-grass, or } \\ \text { Bermuda hay. }\end{array}\right.$

Cows giving large amounts of milk should have more, especially of concentrated feeds, and cows giving small amounts less, than the above rations call for. The student can make up many rations, and make necessary calculations to see if they will be suitable.

Variety of Food. - A general truth in animal feeding appears to be that two or more foods fed in combination with each other, or both fed during the same day, are more digestible than either fed alone. It seems generally 
to pay to add extra feeds to a mixture for variety, even when not necessary to balance the ration.

Additions to Fattening Rations. - It has been found in all experiments in fattening steers on cotton-seed hulls and meal that a little corn meal or rice polish or cheap molasses added to the ration makes the steers fatten faster and finish better. In fattening cattle on corn or kafir corn with stover or hay for roughage, it has been found that a little cotton-seed meal or cotton seed may be very profitably added to the ration. These additions always make the gains more rapid and raise the value of the steers when sold.

Feeding Cactus. - The prickly pear of Southwest Texas, which contains about nine-tenths water, and whose dry matter has a ratio of probably one to fifteen, has been profitably used to fatten beef cattle by adding cotton-seed meal. Dairy cattle also give good results from eating the prickly pear combined with cotton-seed meal and wheat bran. These concentrates balance the pear feed, and the latter makes up the roughage.

Mixed Feeds. - Cirinding and mixing feeds is a very large business. About a half million tons of such feeds are sold in Texas annually. Such feerls are usually worth the money paid for them. Most states now have laws requiring inspection and analysis of all ground and mixed feeds offered for sale. 'These laws protect the buyer's against dishonest mixtures, and protect the honest manufacturers and mixer's of feeds against unfair competition. The laws requiring inspection of feeds and fertilizers are of great value to the people. 
Condition Powders. - The so-called condition powder's and foods, claimed to have high value on account of some medicine contained, and sold at high prices, have been found to have no more value than so much corn meal, wheat bran, and oil meal. It has been established that healthy animals or poultry need no medicine, and that they will be harmed rather than helped by it. It has been found that cooking feeds has generally been harmful rather than beneficial. Soaking, and especially souring, feeds has been also unprofitable.

\section{QUESTIONS}

What do you understand by nutritive ratio" Go to the blackboard and select any feed-stuff in Table 1 and calculate its mutritive ratio. What is a wide ratio and what is a narrow ratio? What is a balanced ration? C'an you pick out kinds and amounts of feeds in Table 1 that will constitute a balanced ration for a certain animal? IIow would Table 1 enable you to estimate the value of animal manures? ()f what adrantage is it to give a number of feeds to animals? What feeds make profitable additions to cotton-seed meal and hulls for feeding cattle? What feeds are profitable to add to corn or kafir corn and hay or stover in fattening cattle? What curious product is fed in Southwest Texas? What does this feed need to balance it? Tell about the mixed feeds so largely sold. What laws are needed to control this business? Are condition powders and medicated foods of any value? Is cooking feeds usually profitable?

Experiment. - Suppose you try feeding a milk cow for a few days in winter on corn meal and grass hay or hulls. This will be quite a narrow ratio. Then try cotton-seed meal and the same hay and note the difference in milk yield.

('alculate the fertilizing value of each ration proposerl on page 2.7 . 


\section{CHAPTER XXXVI}

\section{ANIMAL DISEASES}

Prevention of Sickness. - Every farmer should know something of veterinary science, or how to prevent his animals from getting disease, and how to cure disease, but remembering "an ounce of prevention is worth a pound of cure." Careful feeding and watering a horse, and not driving him too fast after a full feed, will usually keep him sound and well. If he is made sick by overfeeding, followed by overwork, perhaps no amount of medicine will cure him. If fed when thirsty, he is likely to drink too much water after eating and make himself sick.

Contagious Diseases. - Often the carcasses of horses that have died of diseases like glander's and charbon serve to spread these diseases. Vultures and dogs carry the germs from the dead animals to where they infect healthy ones. The bodies of animals dying of contagious diseases should be burned. 'Thousands of dollars' worth of fine, fat cattle often die of a clisease called black-ley because the owners neglect to get a vaccine virus and inoculate the cattle. If horses and cattle are properly inoculated, they become immune for about a year to charbon, a deatly disease often ravaging the large river delta sections of the Gulf States. Many years ago cattle brought from the North, or from the elevated West, to the lowlands of the South, almost always died of what people call arrli- 
mation fever. The cattle that had never had ticks got ticks on them and took the disease we now know as Texas fever, or tick fever, and died. The Southern cattle driven North or West left a deadly trail that killed all Northern cattle crossing it. It is now known that the Southern cattle dropped ticks from their bodies, and these ticks got. on the native cattle, and gave them the deadly fever.

It has been found that even in South Texas, Louisiana, or Georgia, cattle raised by being tied out on cultivated land never have any ticks, and if ticks get on them, they die as readily as Northern cattle. It has also been founct that young calves may get the ticks on them without being harmed, and they become immune. That is, they are free from taking the disease, just as you are free from the danger of measles after having had it once.

Inoculating against Tick Fever. - It has been more recently found that if Northern cattle are inoculated when brought South, they have only a mild case of Texas fever, and usually recover. The inoculation consists of simply injecting into their veins a little of the blood of native cattle that have had ticks. Many thousands of Northern cattle brought into South Texas for breeding have been immunized in this way during the last ten years. The Veterinary Department of the Texas Agricultural and Mechanical College has taken a leading part in the interesting scientific investigations that have been so helpful in controlling the Texas fever.

Quarantine Line. - The Department of Agriculture at Washington indicates the northern limit of the cattle tick by a crooked line rumning across the country from 
the Atlantic coast in North Carolina to the Mexican border of West Texas. This line turns south as it begins to approach the elevated plains in Texas. The last ('ongress made an appropriation to be used in destroying the tick. Active efforts are in progress in almost all the couthern States to kill out the tick in the more northerly sections of the infesterl district. The tick's only means of living is the blood which it sucks from cattle. Therefore, if all cattle are removed from a pasture for two or three months in summer, all the ticks in that pasture will die of starvation. So, by merely dividing the pastures and changing the attle from one to the other, the tick can be killed out.

The people have stock laws in all sections adjacent to the quarantine line, so that no cattle are allowed to run at large. Whenever the Department at Washington finds that a county is rid of ticks, the quarantine line is moved that much farther south. In this way the free zone is from time to time being enlarged.

Advantage of living above Quarantine Line. - To be above the quarantine line is a matter of great advantage to the cattle raiser. Ile can ship breeding stock to or from any part of the North. But his greatest alvantage is that he can ship cattle to any part of the North or West for grazing and feeding. The best grazing is found and most of the feeding is done north of the quarantine line. This makes a remand for cattle that enables the farmer ahove the line to get good prices. The man south of the line camnot ship his cattle north of it, except for immediate slanghter. This, of course, compels him to sell at a lower 
price. Therefore all counties and districts joining the line should coöperate in an effort to kill out the tick and move the quarantine line south of them.

Hog Cholera. - Iog cholera is often carried by a creek or stream from an infected farm to another farm below. Hogs dying of disease should be burned to prevent dogs and vultures from carrying the germs of the disease to other lots or other farms. If an outbreak cannot be prevented by quarantine and sanitary precautions, the best thing for the farmer to do is to divide up his herd into several lots, putting them on high ground, if possible, and carefully removing all sick animals. Medical treatment is of little avail in case of hog cholera. Inoculation as a preventive or cure has not yet been successful.

People used to have very many absurd ideas about animal diseases and their treatment. It used to be very common to see cows and oxen with a number of little holes bored in their horns. This was done to eure a supposed disease called hollow-horn. There is really no such disease, and the cattle got well in spite of the boring. Another supposed disease was hollow-tail, and many cattle had their tails split open and salt and pepper and other remedies put in under the skin. This, too, was worse than useless. Then cows were supposed to lose their "cud," and salt dish-rags were crammed down their throats as a substitute for the "cud." Horses had "hooks" cut out of their eyes, had their mouths burned for lampers, and received other kinds of brutal treatment for real or imaginary diseases.

These notions about animal diseases are only a little 
less foolish than those held by the old negro woman who rubbed fresh milk on a cow's back to get the devil out of her. See Appendix for treatment of animal diseases.

\section{QUESTIONS}

What precautions should be taken to prevent sickness of horses? What should be done to prevent spread of contagious or infectious animal diseases? What diseases can he prevented by inoculation? What causes acelimation fever? What is Texas fever and how is it spreal? What causes death of Northern cattle grazing on land that Southern cattle pass orer? What can be done to save Northern cattle when brought Sonth? What is the quarantine line? Is this line moved from time to time? Is it more profitable to have cattle north of this line or south of this line? (iive reasons. How is hog cholera spread? What are some of the foolish notions people have about animal diseases? 


\section{CHAPTER XXXVII}

\section{ANIMAL HUSBANDRY}

Growing Live Stock and Live-stock Products. - Probably very much more than half of the products of the farms of the country is converted into animal products before final consumption. People cannot eat grass and hay and cotton seed as such, but when these products are converted into juicy beefsteak, tencler mutton-chop, or golden butter, who could wish anything better? All the produce of pasture and meadow lands, virtually all the corn and oats produced, the by-products of wheat, barley, rice, sugar-cane, sugar-beet, cotton-seerl, etc., pass into animal products before they are used by human beings. Even some animal products, like dried blood, tankage, meat-scraps, bones, skim-milk, etc., are ferl to poultry, hogs, or other animals, and re-converted into animal products.

Animal Machines. - In one sense, raising live stock may be considered as a manufacturing process by which bulky, nearly worthless farm products may be converted into valuable concentrated or refined products. A ton of gold-bearing ore having $\$ 5$ worth of gold in it could not he easily handled or shipped; but put the ore through the great crushers and smelter's and get the $\$ 5$ in gold out, and it will not cost one per cent of its value to send it to St. Petersburg or Tokyo. We might have a ton of hay 
on a farm ten miles from a railroad, and it would not bring enough to justify baling and hauling, but we run it through our condensing machine, the steer, and it turns us out 100 pounds of beef and a good lot of manure to emrich the land. 'The by-product, the manure, is of comse too heavy and too low in value to market, but the main product is valuable enough to ship to ('hicago or London. Our condensing machine carries it to the railroar and loads it on the cars.

Another good thing about these living machines is that they-are self-oiling and gather so much of their own raw material. They gather grass and weerls and brush that we could not afford to cut and save, and make them into goods of high value.

Improved Machine. - But we have another highly inproved condensing machine that deserves to be patenter. By consuming a ton of hay, or its equivalent, in suitable mixtures with other food, this machine will turn out for us fifty pounds of fine butter, worth seven or eight times as much a pound as the heef. IVe can afford to ship this product anywhere by express, but for fancy prices we need not ship it farther than our Southern cities.

Other Machines. - The sheep and angora goat convert food into wool and mohair, valuable products that will keep indefinitely.

'The most rapid-working four-leggerl machine we have is the hog. It will make probably as much meat out of ten pounds of feerl as the steer will make out of thirty pounds, but the hog cannot use as coarse raw material as is used by the other animals mentioned. W W would not 
like to eat grasshopper's, bugs, worms, and sliails, as poor (hinese and Japanese children do. But we have a small, cheap farm-machine that does not have to be rum even by hand, which converts all of these things into little packages of rich, palatable human food, sealed up into little air-tight aases, or cans. Can you name this machine?

Machines for Work. - Somewhat as we feed coal and wood into a traction engine and get work, we feed hay and oats and corn into our horses and mules and get work. As the best corn, oat, and hay lands have increased in value to $\$ 5$ and $\$ 150$ per acre, and as horses and feerl stuffs have risen in value, as a necessary (onseduence of ligh land values, people are casting alout to see if they cannot plow with traction engines more rheaply than with horses. But the horse has risen in value in spite of trolleycars, automobiles, and bicycles, and we shall continue to find use or sale for all goor horses and mules we can raise.

\section{QUESTIONS}

Is much of the produce of the land converted into animal products? What substances unfit for human ford may be converted into excellent human food hy feeding to animals? Are any animal products converted into other animal products? What comparison is made of a steer to a machine? What does the cow use ats raw materials and what products does she turn out? What do sheep and angora goats consume and what products are given? What machine works most rapidly in proportion to size? What machine turns out canned food? What product does the horse return? Do high land values make high-pricerl feerl stuff? ('an people plow ecomomically with steanpower?

Experiment. - Ise score carts in Aplendix and practice judging horses and cattle. 


\section{CHAPTER XXXVIII}

\section{RAISING HORSES AND MULES}

Horses on the Plains. - IJorses thrive remarkably well on the Plains and in the dry elevated sections of the great Irest. They seem to winter on the ranges eren better than cattle, and horses raised in that section certainly have muscle, bone, and endurance equal to any horse ilrabia or the Barbary States ever bred. But the land on these plains is rapidly getting too high-priced for exclusive grazing purposes. The five to ten acres of land necessary for keeping a grown animal a year does not yield a net income of more than fifty cents an acre, or about enough to pay a reasonable interest when the land is worth five dollar's an acre. But since these lands for a good distance west of the 100th meridian of longitude have passed the five-dollar valuation mark, ranches are being rapidly cut 11) and sold for farms. So the horse of the future and the cow of the future must be raised more and more under farm conditions and less and less under range conditions.

On the Farms. - To raise horses with the most profit on the farm, plenty of good home-grown feeds and good rich pastures must be provided, and the mares must be matle to earn their living by doing farm work. Mares, in order properly to nourish their young, should have rich milk-producing foorls, like clover, alfalfa, peanut, or pea- 
vine hay, oats, and wheat hann. I colt pushed along with luper nomishment will not only make a larger horse. lut will reach a marketable size a year sooner.

Pure-bred Horses. - It is not desirable that most men should molertake to raise pure-hred horses. While pure-

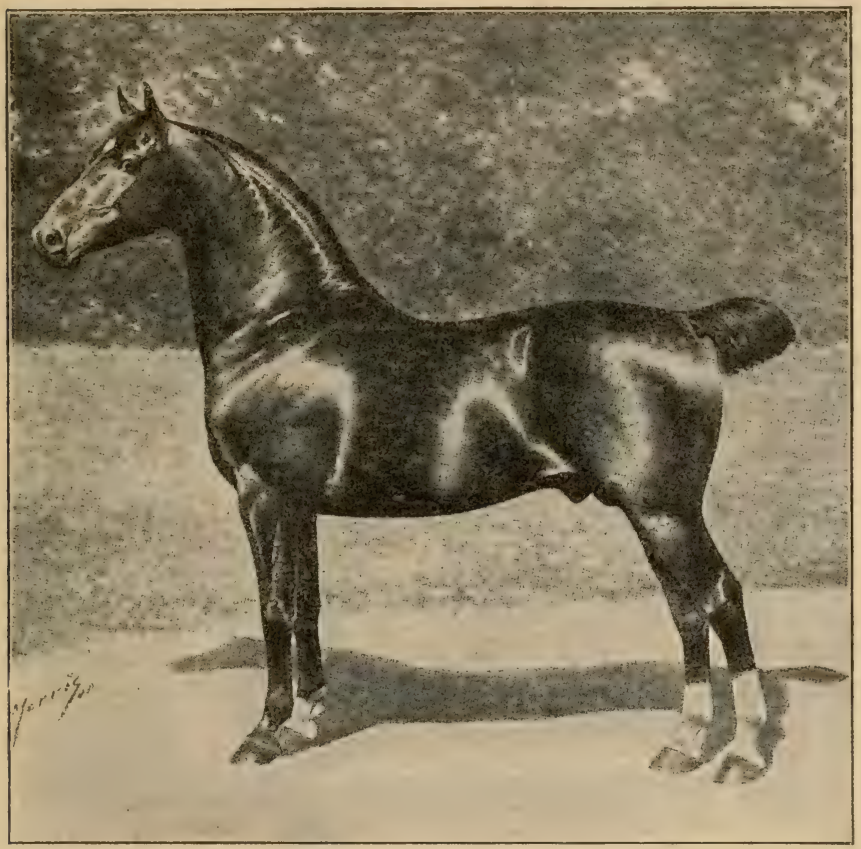

Fic. 93.- - СоАсн ТYPE

hrerl horses, or mixed-blooded horses of special types for special purposes, will find buyers at extra good prices, the majority of farmers are not ready for sperial-purpose horses. Most farmers are not so specialized in their husiness as to want a heary draft horse for hauling. a carriage 
horse, and a fancy saddle horse. They must, for the most part, use horses of general-purpose qualicies, or mules, which are hard to surpass as general-purpose animals.

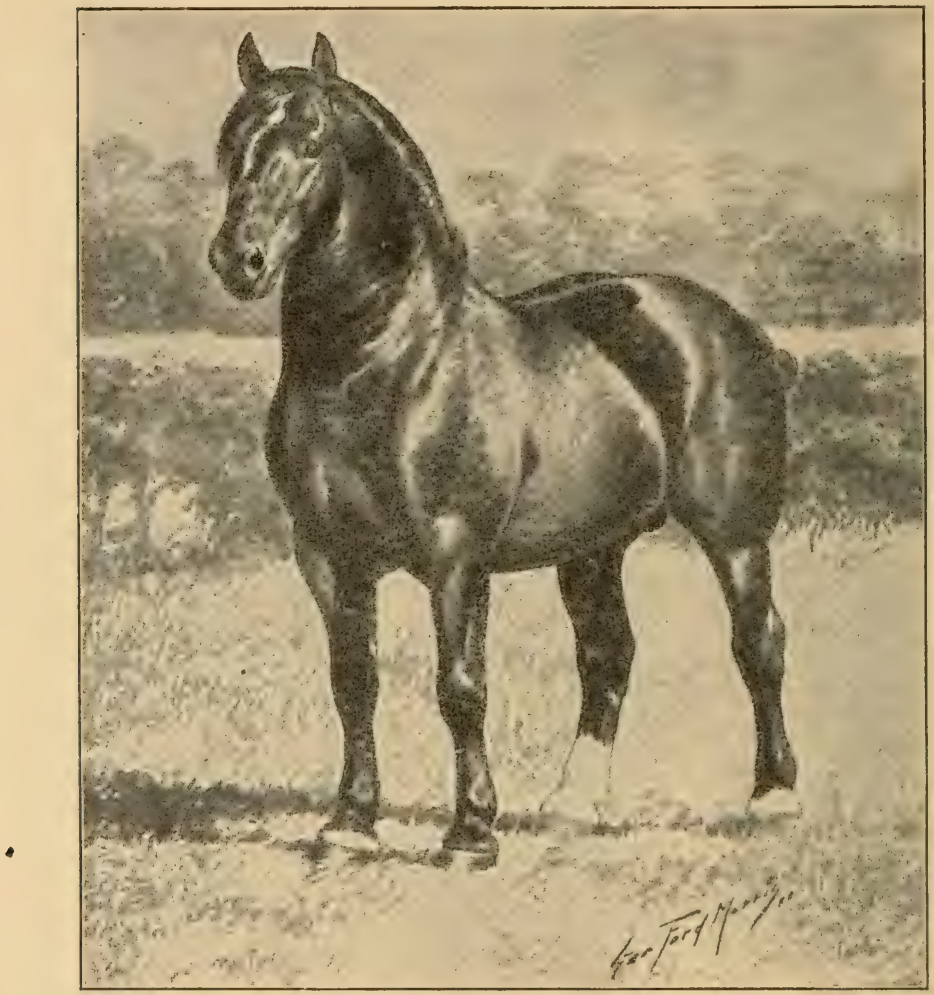

Fig. 94. - Draft Type: Percherox

Under present conditions raising good horses and mules ought to be very protitable. We raise a thousand-pound steer, fatten him, and sell him for five rents a pound, if 
Le is an especially good one. A good mule of the same weight would easily bring fifteen cents a pound; and if the mother earns her feed on the farm, the cost of raising the mule could hardly exceed the cost of raising the steer by more than two or three cents a pound. We have seen that horses eat no more each day than cattle, that their fond is not very much more expensive, and we know horses and mules grow about as fast as cattle.

Classes and Breeds. - The classes of horses are the draft breeds composerl of heary, large-boned, slow-moving types, weighing from 1500 to 2200 pounds; the coach, or carriage, types of st ylish-looking horses, weighing from 1200 to 1f00 pounds, that hold their heads high, pick up their feet well, and combine strength with good speed and style; the light types, including the English race-horse, the American trotter, the near relative of the racer, and the American saddle horse, rather closely related to the last two. Then there are the ponies, such as broncoes, or mustangs, Indian ponies, ete., and the Shetlands.

There are many hreeds of draft horses, including the I'ercheron, Clylestale, Belgian I)'aft, French Draft, English Shire, and others. The coach breets are the C'leveland Bay, French Coach, German Coach, and others. There is much interest in the United States just now in dereloping new breerls of horses in America that will meet the needs of the country better than existing breeds, nurly all of Enropean revelopment. The Department of Igriculture at Washington is undertaking this work. Interest is reviving also in the Morgan horse, certainly one of the best general-purpose horses ever known. 
Siee the Appendix for diseases of the horse and the remedies for these diseases.

\section{QUESTIONS}

Where do horses thrive under range conditions? What is the rasom homses and cattle must he raised still more largely on the farms? What sort of feeds must mares have propery to nomrish their colts? ('an farm mares work and raise good colts? I)o most prople neest pure-lored horses of some type? What kind of horse? suits most men, a special-purpose or a gemeral-purpose horse? What comparison is marle of the costs and selling prices of steers and mulese? What types of horses are named? What hreeds belonging to each tyle? What efforts are being made to derelop new breeds? 


\section{CHAPTER XXXIX}

\section{CATTLE}

CATTLE are now kept for two main purposes, for producing beef and for producing dairy products. The time lias been that cattle, like the buffalo of the plains, Wrere slaughtered for their hicles and tallow. In early times, cattle were kept for work, and this is still to some extent true.

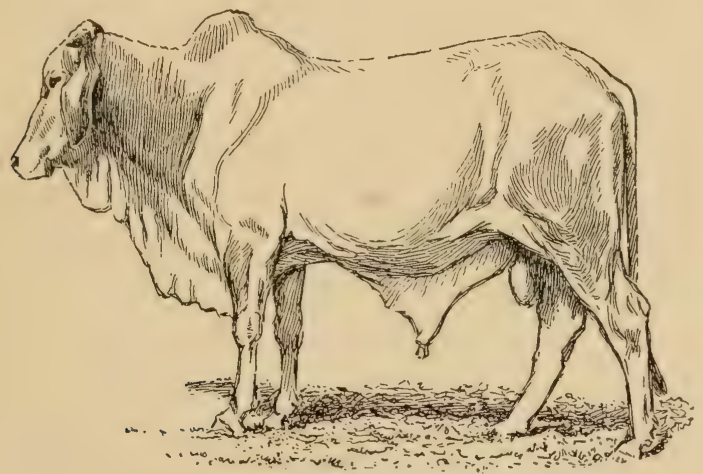

Fig. 95.-Zebu, or Sacred Bull of India

Sacred Cattle. - A different species of cattle is found in India, Java, Borneo, and the South Sea Islands. Some of these are said to be taller than our largest horses, anr some, the little trotting bulls of (eylon, to be not over three feet high. A vast number of cattle is raised in the Chinese Empire, and, so far as the author has seen them, 
they appear to be a cross between the zebu cattle and the European cattle. Some East Indian cattle have been bromght to Texas, Louisiana, and Mississippi. They are very hardy, free from disease, are bitten but little by ticks, and they make fine work cattle and good beef.

Classes and Breeds of Cartle. - () I1 Emopean races of (attle have been bred into more or less distinct types for different uses, and these types into different breeds, each with its own sperial characteristies. Whe have beef "attle, seneral-purpose, or dual-purpose, cattle, and dairy cattle. The principal breeds of beef cattle are the shorthorns, Herefords, Aberdeen Angus, and Galloways. The duallurpose cattle are natives, Devons, Red l'olls, and some strains of Shorthorns, or Durhams as they are sometimes called. Dairy cattle include Jerseys, (ruernseys, IIolsteins, and Ayrshires. The Jerseys and (ruernseys give rich milk, while the Holsteins and Ayrshires give larger quantities of poorer milk.

Dual-purpose Cartle. - I large number of American firmers do not wish cattle that are highly specialized or useful mainly for one purpose. They wish what some term dusl-purpose rettle; that is, cattle that are fairly good for dairying and fairly good for beef. It is probably not true, as some have contenderl, that such eattle are necessarily less profitable than special-purpose cattle. Neither is it true that pure-hreer cattle are necessarily more profitable for all people than native cattle or grades. It is selfom that any good quality is secured and fixed in a race of live stock without the loss of some other desirable quality. 
Value of Breeding in Beef Animals. - First. The beef breeds of cattle grow larger than native cattle, particularly the native eattle found in the South.

recond. Beef-hred cattle always dress out a higher pereentage of beef for a given live weight than native or
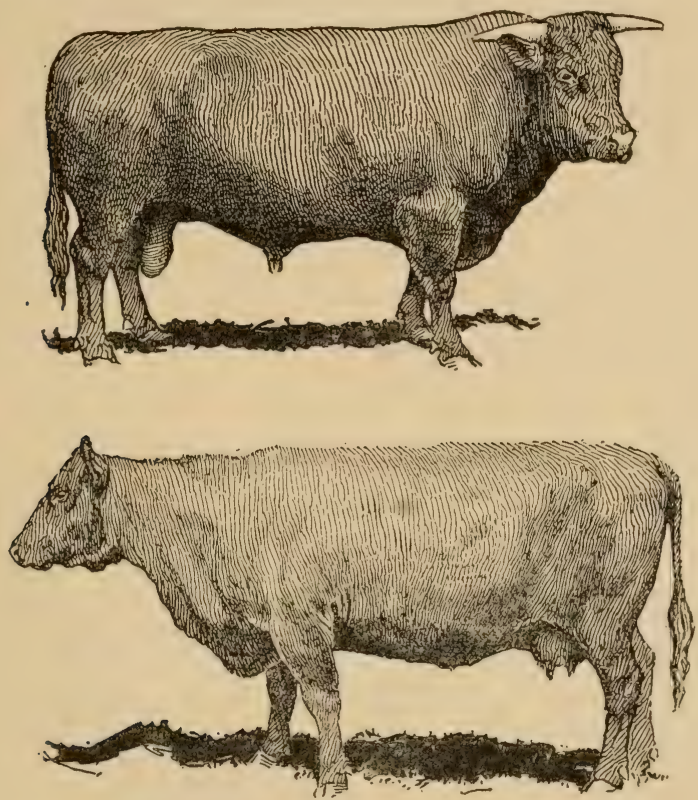

Fig. 96. - Dual Purpose Cattle

Devon Bull above

Red Polled Cow below

dairy-bred cattie equally fat, - in a large number of experiments as much as two to ten per cent.

Third. The dressed carcass of a heef-hred steer contains less tallow, which is a low-pricerl product, than the carcass of a dairy-bred steer. 
Fourth. In a number of tests mate by the experiment stations, the loin steak and rib roast of the beef-bred steer's have been judged to have a higher value than the same colts from steer's from dairy or sorub cattle. In othere tests no difference in value of these cuts was made.

Fifth. It is generally held hy hutchers and parkers that beef-bred cattle produce meat with the fat and lean hetter mixed than is the case with other cattle. There is. therefore, probably a difference in value in favor of the carcass of the beef-brexl steer, which has not always been taken into account by experimenters.

Sixth. The highest grades of all prorlucts come nearel' bringing full values than common grades. All slaughter tests made by the stations indicate that meat packer's make more profit out of dairy-bred and common cattle than they do out of the better grades. The uniform colors and better appearance of the latter doubtless help them to bring fuller values.

Fine Stock not Rustlers. - The short-horn and Holstein cattle have been fed and bred to produce large frames and great weights. Yet they are the poorest rustlers of our breeds of cattle. Many farmers, not knowing this peculiarity, have expected their short-horn cattle to rustle like native cattle, and have been disappointed to see their fancy cattle die or become the porrest cattle in the neighborhood.

The average farmer of the South, who is generally not a stockman, often buys broad-backed, pure-bred hogs, and turns them into the wood-lot to "root, hog, or die." If the hogs survive, they soon degenerate into thin, ugly 

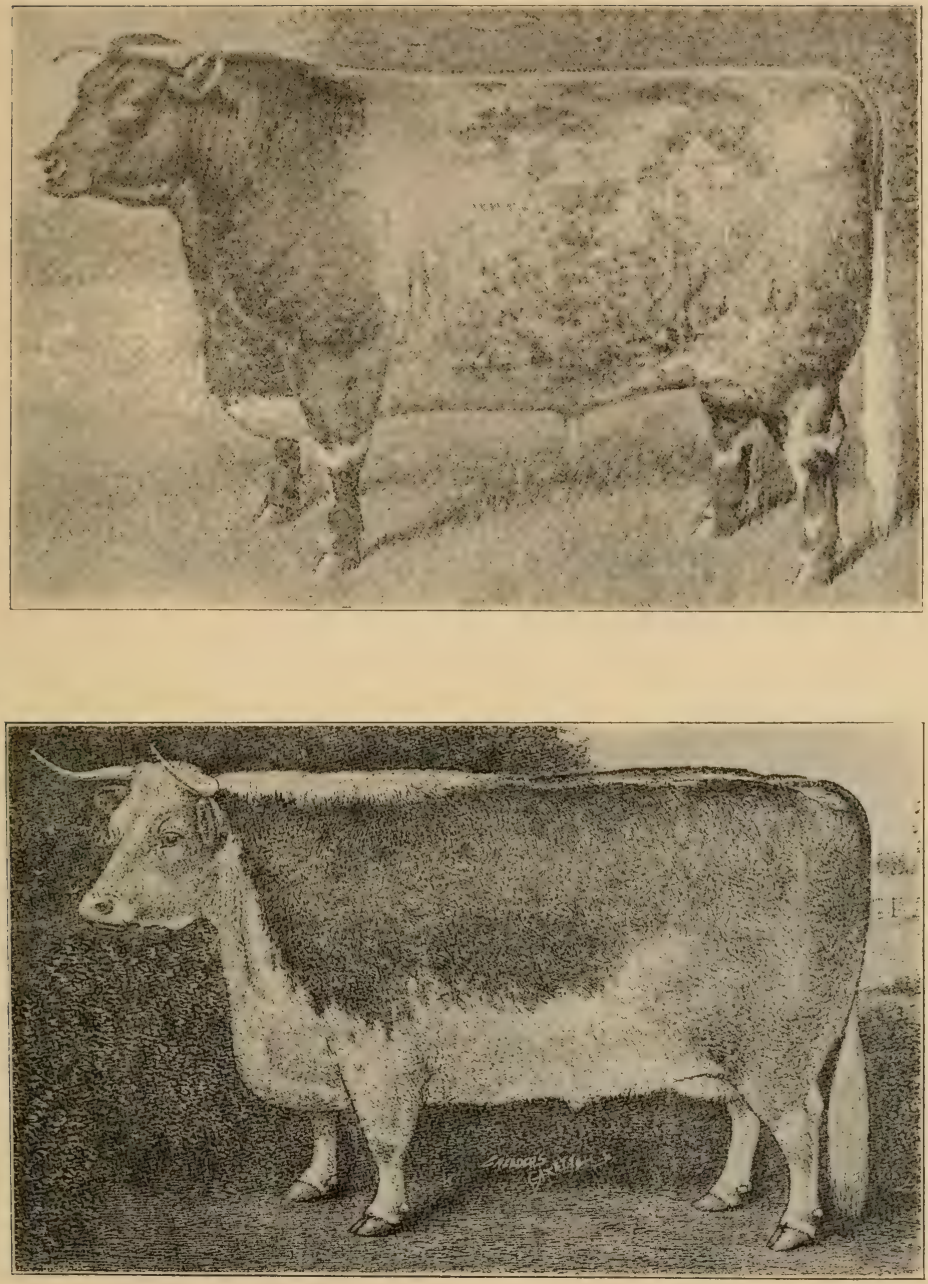

Fig. 97.-BefF Cattre:

Grade Shorthom Steer above Grade Hereford Steer below 
razor-backs. Every farmer should be impressed with the fact that fine stock requires extra care, and that feed counts for far more than breed.

\section{Pure Animals gain no More for Feed eaten than Scrubs.}

- There is at present a very prevalent but erroneous impression that a bushel of corn will produce more growth when fed to a pure-bred beef animal than when fed to a dairy-bred animal or native. Surely, if breeding has improved the alpertite and digestion of beef animals, the salme sort of breeding must have been pursued with dairy animals, because milk cows eat and digest large amounts of food.

It has been demonstrated again and again that an animal of no one breed or type eats any more, digests any hetter, or gains any faster than an animal of any other hreed or type, when both are of the same size and condition at the time the test is made. It has also been proved that animals of no fixed breed or type-natives - eat as much, digest as well, and gain as fast as animals of fixed types or breeds, if all are of the sime age. size, and condition when the feeding test is made. To verify these assertions, reatlers atre referred to Ilenry's "Feed and Feeding," page :37t: Iowa Bulletins, 20 and 81; Kansas Inulletin, 111; Minnesota, No. 73: Wiseonsin, No. 104: ancl Mississilpi, No. T6, all of which bear on the subject.

Early Maturity. - It is commonly claimed that purehred, meat-producing animals mature earlier than the other animals. If maturing earlier means to get grown quicker, it is an erroneons claim. The truth seems to be that a Jersey calf, heing smaller when burn than a short- 
horn calf, does not eat quite so much or grow quite so fast as a shorthorn. If, then, both calves are fed all they can eat, the Jersey would probably grow larger than is usual with that breerl, hut, being all the time a little smallere than the shorthorn, eats a little less, gains a little more slowly, and reaches maturity at about the same time.

If early maturity is mulerstood to mean a tendency to get fat at an early age, it is certain a beef-bred steer will not fatten at an earlier age than a. Serser, if both are fed equally well. If early maturity is molerstood to mean that the flesh of the beef-bred steer will be of better (quality, or riper, at an early age, than the flesh of the dairy-bred or mative steers, it is generally believed that this is true.

Cattle in Texas. - The state of 'Texas has more cattle than any other state in the Union, sonething orer eight million head, or about one to every twenty acres. In certain rich districts of IIolland, I)enmark, and Belgium one cow to the acre may be found, but food must be imported to help feed these cattle.

Cattle enrich Land. - If 'Texas depended on feeding cattle to enrich the land, as some countries do, the ome cow to twenty acres would hardly manure the garlens and truck patches. It is said that the present dairy districts of $\mathrm{W}$ isconsin were formerly grown in wheat until the land became so exhausted that the people, being no longer able to make a living by raising wheat, turned their attention to dairying. They are again unable to raise wheat profitably. but it is becanse the soil has be- 
come so excessively rich as to cause the straw to grow too tall, so that it falls down, or "lodges."

Cattle and Rotation. - In many sections where cattle and other live stock are regularly kept on farms, pasturing has been generally introduced as a part of the rotation. But in the South the lands are so often irregular in quality that those which are not suited for cultivation are usmally selecterl for pasture. By keeping cattle in

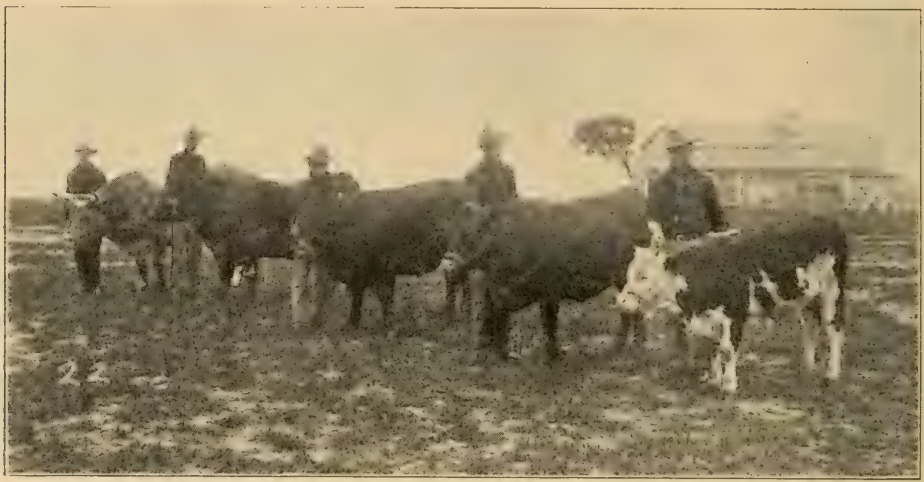

Fig. 98. - Showing: Befe Cattle at Texas Agricultural and Mechinical College

barns only a very small part of the year, and allowing them to rum in pastures not belonging to the farm proper, conthern farmers get far less value from the manure than the Northern farmer, who stables and feeds his c:attle for six months in winter, and pastures them on a part of the farm land in summer.

Poor Stock due to Poor Land. - The poorest cattle in the Enited States, perhaps, are those raised on the pine mordows of Florida. West of this, along the pine flats 
of Georgia, Alabama, Mississippi, and along the coast lrairies of Louisiana and East Texas, the cattle are still small and inferior, and grow slowly. And the hogs in these sections, when left to gret their living from the woods and forests, are thin, ugly little razor-backs. This gencral inferiority of the live stock is not entirely, or mainly, due to poor breeding, as most people say. The grasses that grow on poor land in wet, warm countries are coarse and innutritious. The santy, poor food for hogs is so scattered and difficult to find, and requires so much traveling and rooting, that no other type of hog would find enough to live on.

As we go west along the coast prairies and reach the rich river deposits, we find much better cattle. Still farther west, we reach drier, richer land and better cattle. North and northwest, we have still better cattle, regardless of breeding, although the cattle are generally better bred.

When the small cattle of the coast marshes of Louisiana and Texas are given a year or two of grazing on the nutritious grasses of the Panhandle, they approach the well-bred Hereford grades in flesh, shape, and quality.

Rich Land, Rich Food. - It has been suggested that the Texas ferer tick produces in the blood of Southern cattle a slow, constant poison that keeps them from growing and gaining fast like Northern cattle. While this is probable, the difference is due more to difference in the richness of land, and consequently in the nutritive qualities of the feed. It is well known that grass grown on land rich in nitrogen will be generally richer in protein 
than grass grown on poor land; also that grass grown ()n land rich in lime is much richer in hone-making material than that grown on poor, sandy land. It is well known. that the richer any grass is the more rligestible it is. Cattle living on coarse marsh grass must wat a large bulk of it to get even scanty nourishment, and they grow bigbellied and appear to have small quarters. With two years of grazing rich Northern and IV estern grasses, these cattle become round-bodied, respectable-looking animals.

Again, when cattle far south are well fed on cottonseed meal and hulls, corn-meal, rice-loran and polish, blackstrap molasses, and other rich forol, they gain weight rapidly and become in shape and quality not greatly inferior to Northern cattle, equally well fattenerl.

Dairy Cows. - Very few direct tests for milk and but ter liave been made of herds of dairy-bred cattle as compared with scrub cattle. Individual cows of all breeds vary so much in the amomnt of milk and butter they gire that it would be axceedingly difficult to seroue very definite results as to the relative producing capacity of the different hreeds. The tests of the dairy-hreeds against each other have been very unsatisfactory. These tests have not proved one breed more valuable than another.

The truth is, one breed is best for one man in one location, and another breed is hest for another man in another location, and so on, and the differences are probably not great in any case. Still other men would do hest with a general-purpose, or dual-prippose, cow, whether of a distinct breed or not.

One station in testing the hest types of coms, as shomm 
on page 288, against beefy types of cows, found, in extreme cases, that the butter made from the latter costs fifty per cent more in food eaten than the butter made from the former. It must be borne in mind that some natives, dual-purpose cors. Shorthorns, and even Herefords, will be better dairy cows than some Jerseys and Holsteins, but as a rule better dairy cows will be found in the dairy breeds.

There will be found good cows and poor cows in all breeds. Average cows of all breeds are perhaps hardly profitable as dairy animals; yet by rigid selections profitable cows can be obtained from all breeds. Pure-bresl animals do not make up one per cent of all animals in the South. Therefore, in selecting a dairy herd, one has so many native and grade animals to choose from, that he may easily gather from among these an excellent herd. Grading up native and grade herds by the use of pure bulls of dairy breeds is the plan followed by most successful dairymen.

See Appendix for diseases of cattle and their treatment.

\section{QUESTIONS}

What purposes are cattle kept for? Do all farmers want specialpurpose cattle? What are dual-purpose cattle? Do all farmers need pure-breed cattle? What disadvantage do the larger breeds of cattle have? What mistakes are made with fine hogs sometimes? What sort of treatment must improved stock have? What sort of animal will gain most for a given amount of foorl eaten? What are the real advantages of beef-bred cattle? Are these advantages as large as many believe? Which does the buyer make more profit on, the beefbrerl or the scrub steer? What other reason is given for better prices paid for beef-bred steers? Does there appear to be any truth in the 
common claim that pure animals mature earlier than grade animals when both are fed alike? What comparison is made of a Jersey and a Short-horn calf? Do heef-steers fatten at an earlier age than other steers, if fed alike? What have tests of dairy cows proved? Is there any best breed? Which is more important, feeding or breeding? What state has most cattle? Why do cattle not serve to enrich land as much in the South as in the North? Where are small, sorry cattle found in the United States? Is this inferiority owing to poor breeding'? Where are better cattle foumd? What makes the poor cattle on the marshes and pine meadows? What change takes place when these small cattle are grazed on rich land farther north? Why is the range hog a razor-back? Are grasses richer and more digestible if grown on rich land? Cin we make good eattle ont of sorry Sonthern rattle by feeding them well? What are some good feeds for this purpose? 


\section{CHAPTER XI}

\section{HOGS, SHEEP, GOATS, POULTRY, AND BEES}

Different Types of Hogs. - There are several $t_{y j}$ pes of hogrs. The Poland-China is generally spoken of as a lard and side-meat hog. I3ut the proportion of lard and fat meat to other parts in these hogs does not differ widely from that in other hogs if they are fed and handled in the same way. The kind and amounts of food eaten change the products more than differences of breed. The Tamworth, which is prized as a bacon hog, is supposed to produce strips of bacon with lean and fat nicely mixed. 'This tendency, however, is seriously interfered with when the Tamworth is highly fed on fattening food. But when pastured and fed skimmed milk, shorts, bran, etc., it produces the nice lean bacon desired, and so does the Berkshire or Yorkshire. Here, again, the feed has more influence than breed. The finest hog-meat product of the world is the Smithfield ham, cured in Virginia from razor-back hogs that run half wild most of their lives in the woods. When they get nearly two years old, their owners let them run on peanut and sweet potato patches, and then feed them awhile on corn before killing them. A hog so raised and handled will have a larger proportion of lean meat, and the meat will be better flavored than that of rapidly grown and fattened hogs. 
Feeding Test. - Bulletin 104 of the Wisconsin Experiment Station gives a most interesting account of feeding a large number of pigs from birth to maturity. Some of these pigs were pure Texas razor-backs, some Poland-

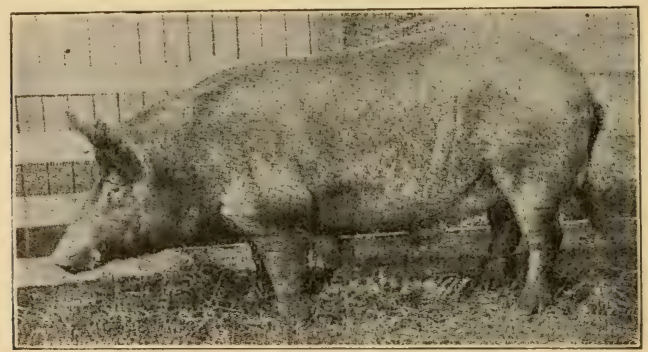

Tamworth

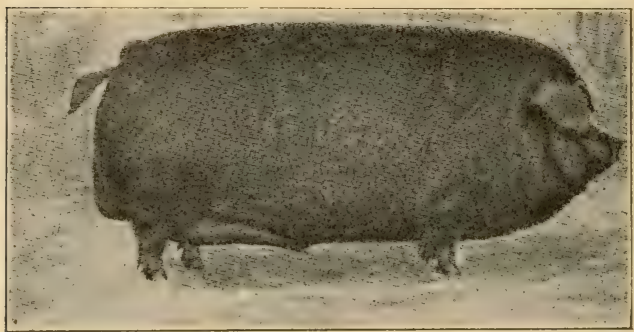

Duroc ·ersey

Fig. 99. - BreEdos of SWINE

C'hinas, and some Berlishires; and others were crosses between razor-backs and the pure breeds. The genuine razor-backs did not make as good gains as the pure-bred hogs, but they dressed ont nearly as well, and actually made each hundred pounds of gain on a little less foor than the others. This and numerous other experiments 
IOCG, SHEEP, GOATS, POULTRY, ANI) BEES $27 T$

prove that feed amounts to more than "breeding" in making a meat animal.

It is true with hogs, as with all live stock, that when the animals are small and young, a given amount of gain

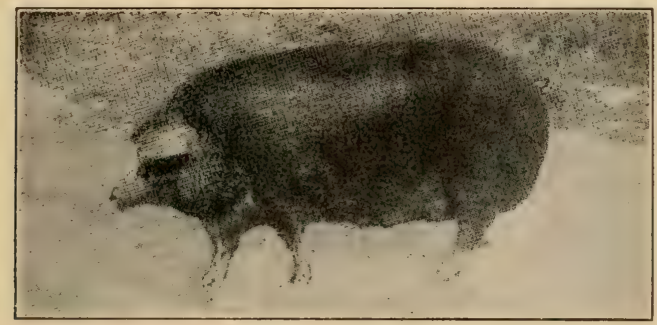

Poland-China

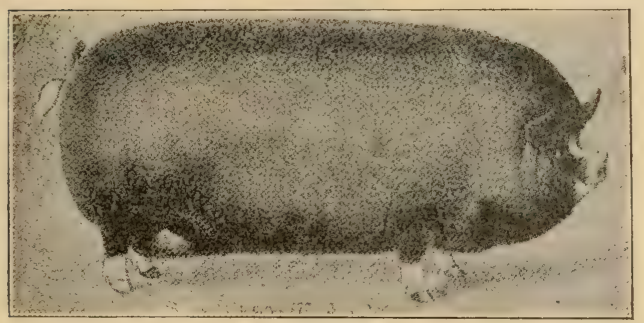

Berkshire

Fig. 100. - Brenes of Swive

in weight can be made with much less food. For instance, with suckling pigs, one and a half pounds of dry digestil)le food in milk or other food material will produce a pound of growth. In growing from thirty to one hundred pounds in weight, about two and a half pounds of digestible food will be needed for each pound gained. In growing from one hundred to two hundred weight, about 
four pounds of digestible food to each pound gained will be needed; and in growing from two hundred to three hundred weight, probably five or six pounds will be required. So it can readily be semn that hogs should not be grown very large, if we wish to make most profit.

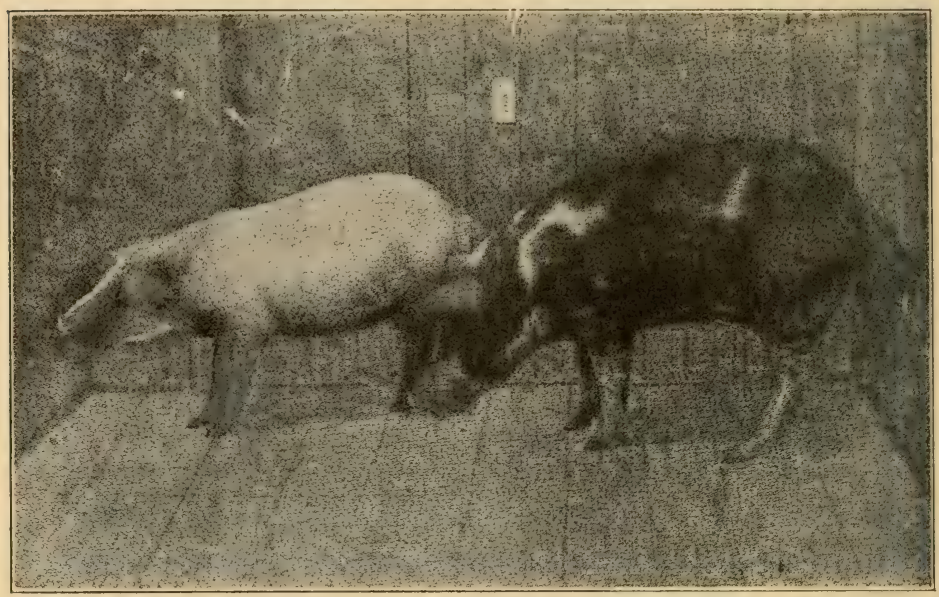

Fig. 101. - RAZor-backs for WANT OF FeED

Pasture for Hogs. -- Pasture is very necessary in order to raise hogs cheaply. Many people keep hogs in a dry lot and fatten them on corn. Corn has not enough protein, or muscle-making material, to cause young hogs to grow economically or rapidly.

Pork raised on lrigh-priced corn, fed in a dry lot, certainly costs over ten cents a pound. One or two pounds of corn will usually make, when fed to young hogs running on good green pasture like vetch, clover, alfalfa, or rape, a pound of growth. 
HOGS, SHEEP, GOATS, POULTRY, ANI BEES 27!)

With oats, vetch, bur clover, rape, and other crops for winter grazing; and with sorghum, peas, and green corn

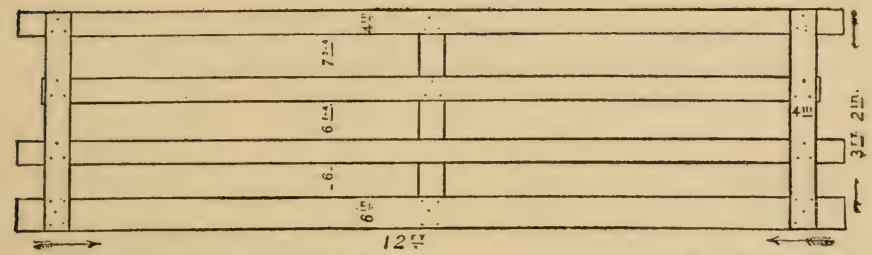

Fig. 102. - Movable Fence

for summer ; and peas, peanuts, sweet potatoes, chufas, corn, kafir, ete., to fatten off the hogs in winter, pork can be raised very cheaply in the South and IVest. With a variety of crops

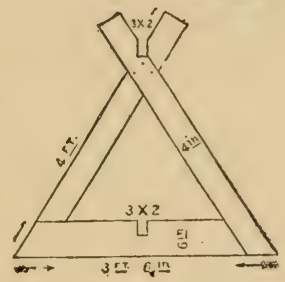
like the ones mentioned, and small amounts of corn, these sections could raise bacon hogs enough to supply the world. Fed in this way, almost any kind or breed would make good bacon hogs.

To handle hogs in this way would require a good deal of fence. A suitable amount of movable fencing built in panels, as shown in Figure 102, would go far to meet this difficulty.

Sheep and Goats: where grown. - Most of the sheep and goats of the country are now raised on the dry lands of the West, and on lands that are too dry and rough for cattle to thrive well. The sheep of the West are almost entirely of the Spanish Merino type, or finewooled sheep, but they also bring about as high prices for mutton as the mutton breeds. On the farms of the 
country many sheep are raised, mostly of larger types, known as mutton breeds. 'Their wool is generally coarse, and some of it is so long that it can be combed out straight like hair. There is no doubt that they grow heavier fleeces in the North and on the elevated, cold

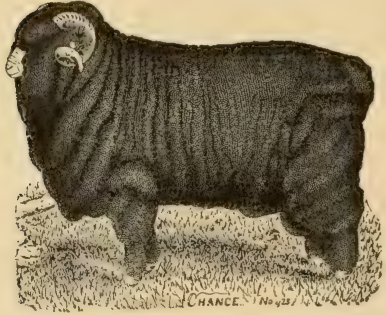

(l

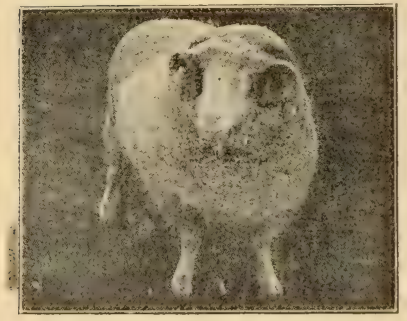

b)

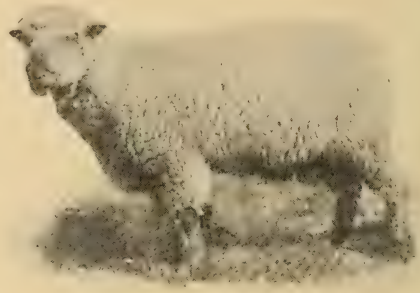

(.

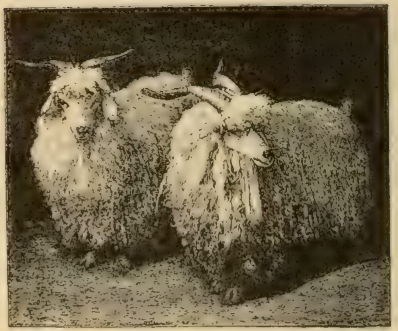

(1)

FIG. 103. - SHEEP AND GOATS

$a$. Merino; $b$. Horned Dorset; $c$. Southdown; $d$. Angoras

limds of the Rocky Mountain States than they do on the lowlands of the South. Sheep, like all other animals, grow heavier coats in cold countries. In the pine woods of the Gulf States, a good yield of wool is three pounds a head for range sheep. North and West, eight pounds 
are more often got, and individual sheep have frequently produced fifty pounds in a season.

Food and Manure. - Sheep eat almost any kind of weeds or grasses, and are useful on the farm for cleaning pastures of weeds. They eat a larger proportion of concentrated feed than cattle, and produce richer manure. There is an old saying that "the sheepis

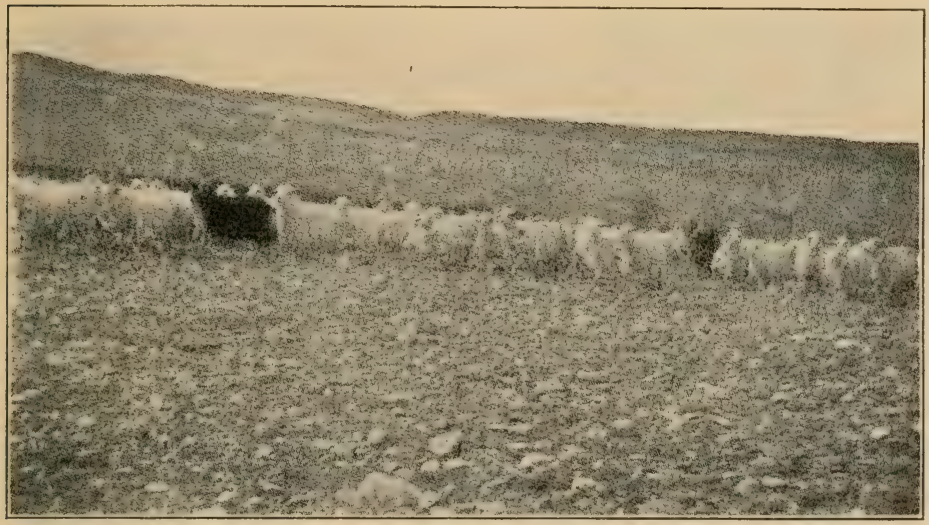

Fig. 10t.-FLock of ANGORAS

foot is golden," which probably means that the sheep makes money for its owner by enriching the land. It: was once thought in England that cattle and sheep' enriched land by blowing their breath on it when eating grass. The people no doubt saw greater improvement in pasture land than the manure seemed to account for. Who knows but that the manure contains colonies of bacteria of highest value to land, which the cattle and sheep, in tramping over the pastures, spread from 
place to place? Would not that be almost as curious and interesting as enriching the land with the breath?

Profits in Sheep. - Sheep make about as much growth for a given amount of food eaten as do cattle, and for some years have sold rather higher than good cattle and much higher than average cattle. They give their wool product extra, which is an item of considerable importance. Sheep, then, are much more profitable than beef cattle, if they can be grown without too much trouble in fencing, protecting from dogs, wolves, etc.

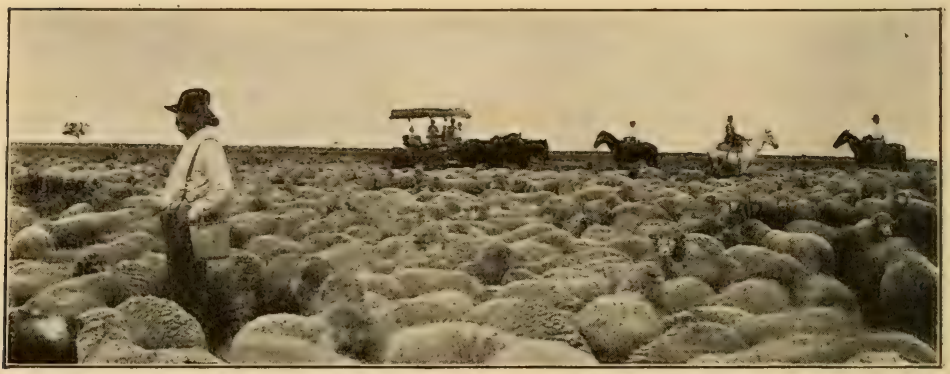

Fig. 105. - Sheep Ranching IN The West

Angora Goats. - A great deal of interest is now being taken in Angora goats, not only in the semiarid regions, but in the rainy sections east, where they are prized for cleaning up briers, bushes, and rubbish, and making the land easy to clear. The mohair trade of West Texas, New Mexico, Kansas, and other states is becoming important, and prices received are profitable, but so far no product has been got equal to the mohair of Turkey and Persia. Whether this is due to the fact that the 
HOGS, SHEEP, GOATS, POULTRY, AND BEES 28:)

goats in this country are not pure, or to some deficiency in the climate, we do not know. The Angora makes good mutton, and the skins sell for a good price.

Poultry. - Poultry$\mathrm{raising}$ is perhaps about as large in total returns in the United States as wheat grow-

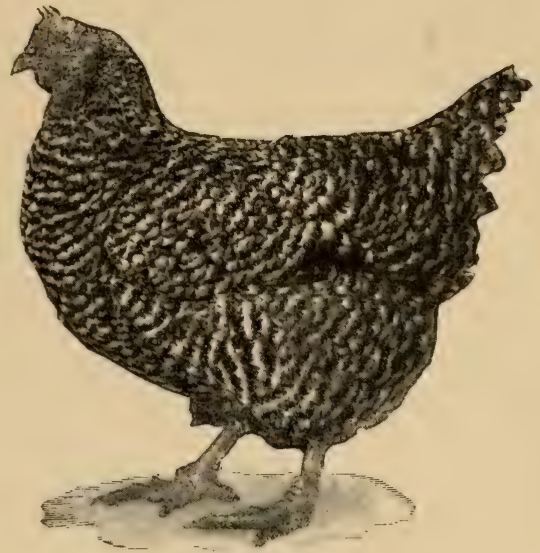

Fig. 106. - Plymouth Rock ing, but it is carried on generally in a small way by nearly everybody, everywhere. The Chinaman makes as much

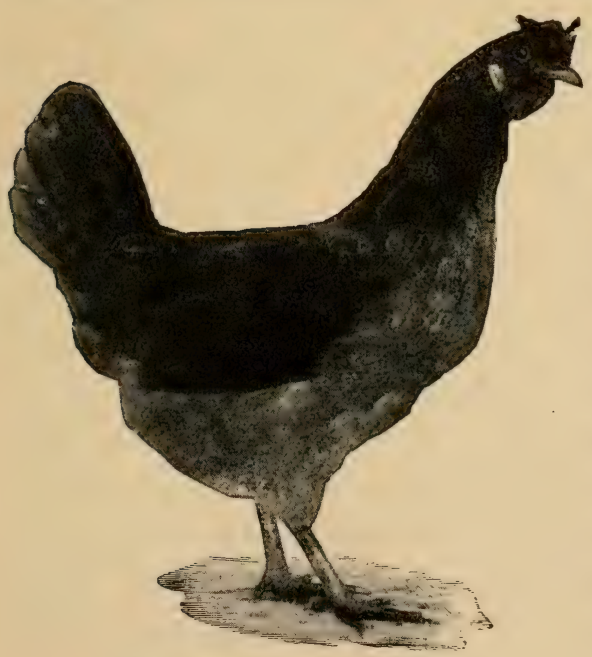

Fik. 107. - Brown LeghorN food on a given area. of land covered with water in the form of fish ponds as he can make on the best garden. A certain range for poultry will perhaps furnish bugs, worms, insects, seeds, etc., enough to produce meat and eggs to a high value as compared with the crops that might be grown on that range. 
('hickens are kept on a comparatively small area near the house. Turkeys and guinea fowls go long distances in search of their food. They may be made of very great value in destroying looll weevils. They are both very

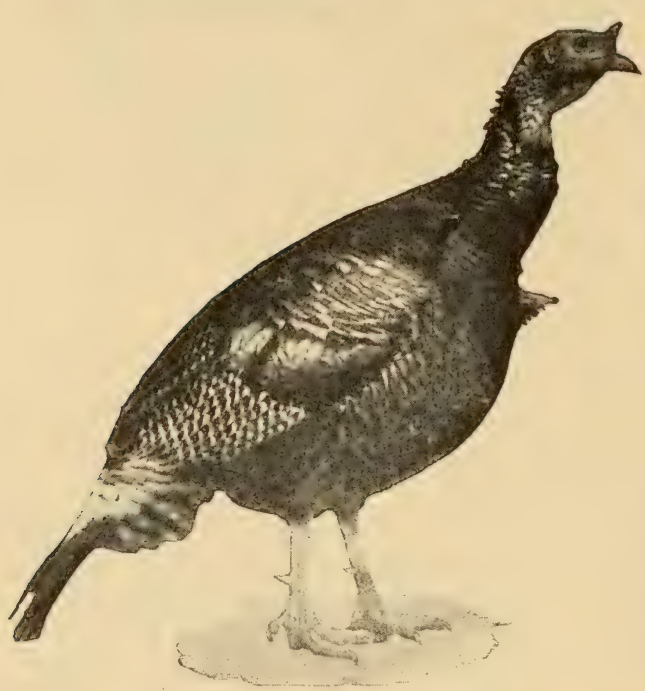

Fig. 10S. - BRONZE GOBBLER profitable fowls to grow, the guinea fowl being the best eggproducer on the farm. Geese are not only valuable for their feathers and for their meat, but may be made of great assistance to cotton farmers. In the districts where hoeing is expensive (nl areount of erath grass, it is not too much to say that a surose to each acre of cotton will save half the expense of hoeing.

Three types of fowls are shown in figures above.

Bees, like fowls, convert something that would be lost without them into money. Sometimes an acre of land, devoted to certain crops, will afford several dollars' worth of honey. Certain large areas of country, partly forest, have been estimated to furnish over a dollar's worth of honey to every acre. 
Nothing is more pleasant, instructive, and profitable to boys and girls than a few colonies of bees. They often make $\$ 5.00$ a colony a year. If you procure a little book or bulletin on bees, you will learn to handle them easily and can make money on them.

\section{QUESTIONS}

What is usually understood as the lard and side-meat hog? Why is the Tamworth called a hacon hog? Does feeding or breeding most influence the proportions of fat and lean meat? Are other breeds good bacon hogs? Could the Tamworth be fed into a lard hog'? Will the native hogs make good hacon hogs? IIas any experiment indicated that native hogs are good feeders? Why should hogs not be grown large? (xive different amounts of dry feed needed to make a pound of gain on different-sized hogs. Can hogs be raised profitably on corn alone? What must be chiefly provided to grow hogs? What are some different pasture crops for hogs suitable for different seasons"? Where are most of the sheep of the country raised? What sort of sheep are raised on the ranges? Do merino sheep sell well for muttmin? What kinds of sheep are grown more on the farms? Where will sheep produce most wool, and why? What sort of food do sheep eat? Do they enrich the land? What did people once think cansed stock to enrich land? How about foor eaten, growth made, and prices: received for sheep as compared with beef eattle? What extra product do sheep give? Where are angora goats found mostly? What special use is made of them in the last? Is the mohair as fine as that of Turkey? Tell the advantages of raising poultry. Tell something of bees.

Experiment. - Suppose you put a razor-lack shoat in one pen at home and a pure-lyed shoat of about the same size in another. Feed them all they will eat and see if one eats more than the other. Weigh them when you first put them up, and weigh them at the end of a month or two of good feeding. See if their increase in size and weight is the same. 


\section{CHAPTER XLI}

\section{DAIRYING}

Different Products. - Successful dairying, combining as it does farming and manufacturing, requires a high degree of skill and plenty of industry. Producing milk to be sold as such, cream for city trade, making butter, cheese, and condensed milk, all afford means of marketing milk. Milk is now being shipped by train loads as far as a hundreel miles to large cities. Cream is shipped in car loads from Chicago to New Orleans. Butter and cheese, of course, can be shipped almost any distance, while condensed, eanned milk is largely exported to South Americat and Oriental countries.

Silage, or ensilage (green corn cut in short lengths and kept green in a big air-tight room, or silo), is coming to be a standard dairy feed for winter.

Milking machines are now coming into use and promise great saving in labor. So far the machines have not been able to milk quite so thoroughly as the hand milker, but this will doubtless soon be accomplished.

Elements of Success. - Goorl cows, good, rich pastures, and plenty of feed of suitable kind and variets, and good dairymen, are the conditions most necessary for suceess. Pure-bred enws are by no means necessary. Most of the good, profitable herds of dairy cows in this country 
are grades: that is, crosses between native cattle and jure-bred cattle of dairy breeds. Some grade cattle have been rossed with pure-bresls for so many generations that they are practically pure. Very much of the dairy product of the country is made from well-selected and wellcared-for native colvs.

The records of such herds are often excellent as compared with grade and pure herds. In this business

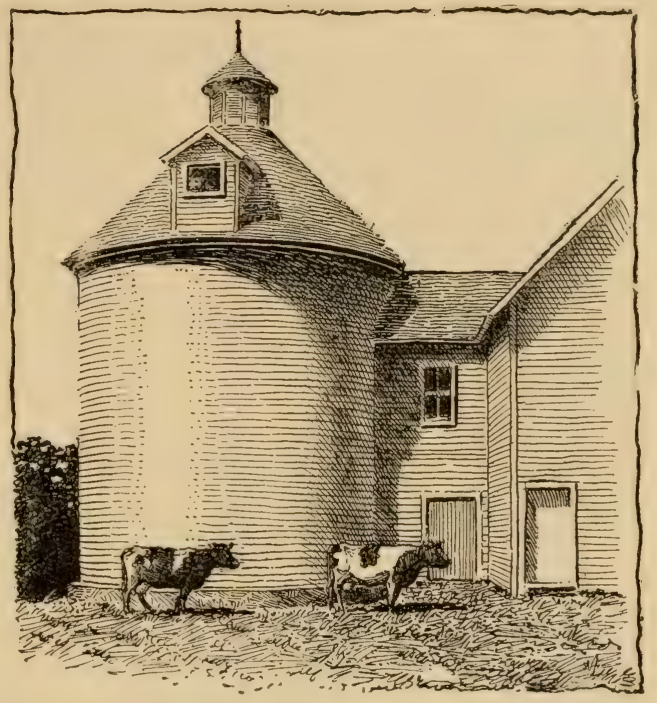

Fig. 109. - Round Silo

good feeding and proper handling of the cows count for more than breeding.

Dairying South and West. - People in the Southern States and the far IV estern States have not engaged extensively in dairying. The Southern people have been busy with cotton, tobacco, cane, and rice; and it is said the ranchman of the plains will not milk a cow because he cannot do it on horseback.

Milk for Home Use. - When only two or three cows are kept simply to get milk and butter for home use, perhaps 
the plan of taking part of the milk and letting the calf have the rest is not bad. Milking in a small way is apt
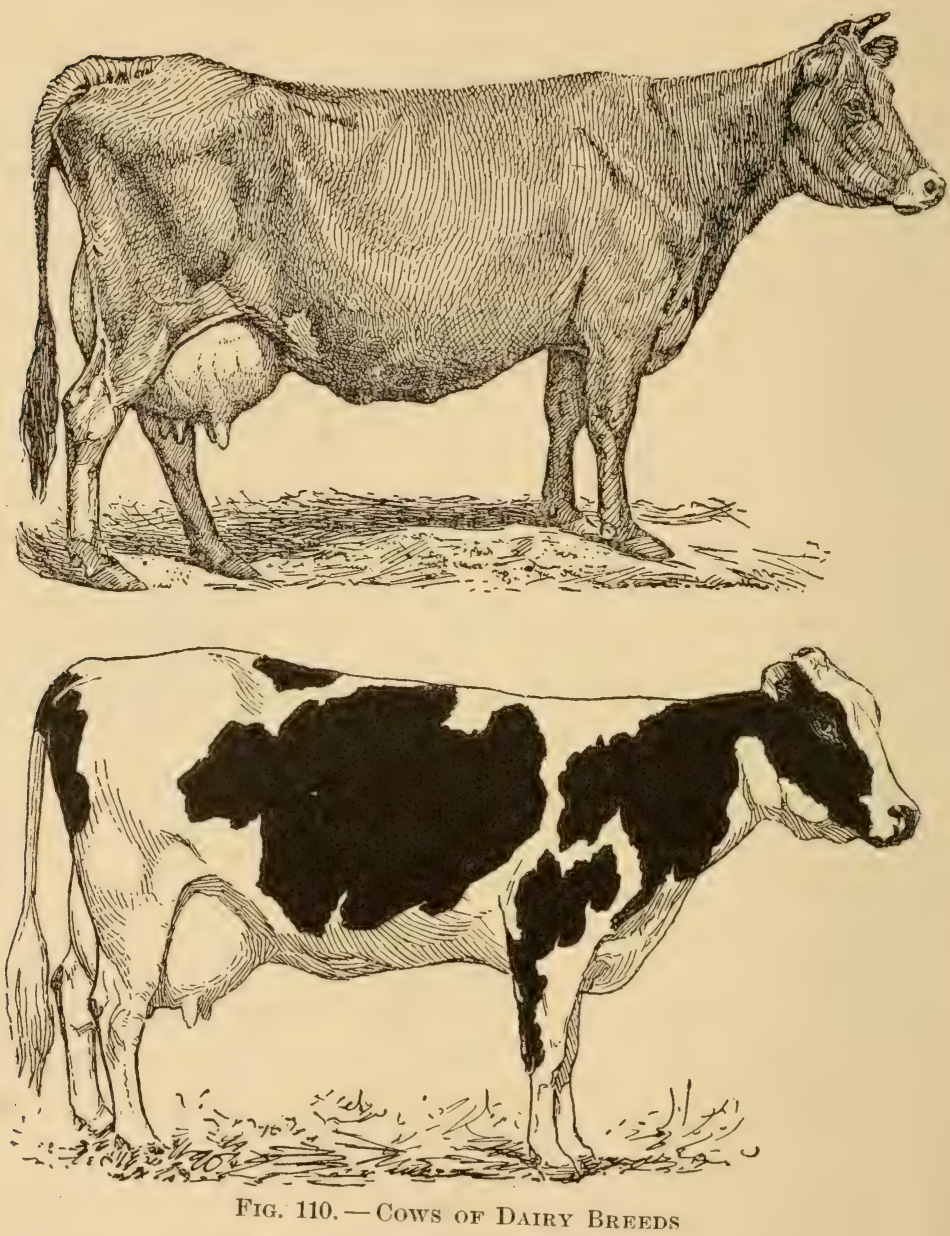

Jersey, above; Holstein Dehorned, below 
to be irregularly and more or less carelessly done. The calf does good, thorough milking, and that keeps the cow giving milk longer than if she were not properly milked. If the cow runs in the woods or in a large pasture, she will come home regularly to see her calf.

Commercial Dairying. - People who produce dairy prorlucts in a commercial way cannot afford the time necessary to rope off calves and to wait for them to "bring the milk down." Neither can the dairyman afford to give the calf the richest milk, the "strippings," which is three times as rich as the first milk drawn. A commercial dairyman must wean his calves when they are a day or two old, and teach them to drink skimmed milk from a bucket. He must also teach them to eat corn meal worth one cent a pound instead of butter fat worth thirty cents a pound. He must drive up his cows regularly, feed them well, and milk them thoroughly. Many people in the South think their native cows would not give milk without suckling calves. If the calves are taken away young, nearly all the cows will give their milk, just as Jerseys do.

Crude Methods. - People making butter for their own use only often have very crude ways of handling milk and making butter. The milk is set in pans, and the cream continues to rise till the milk clabbers. In summer it clabbers perhaps before two-thirds of the cream rises. In fall, winter, and spring it can stand longer, and somewhat better results are obtained. If an attempt is made to churn all the milk, the necessary work is great; the temperature of milk will have to be so high that the butter will be beaten into a sort of soup, and 
it will be white and so mixed with buttermilk that it will not keep long. There is much of the butter' fat left in the buttermilk under these circumstances. When cream is churned at a high temperature in summer, or when heated too much in winter, the same sort of hutter is made, and the losses are also great. With

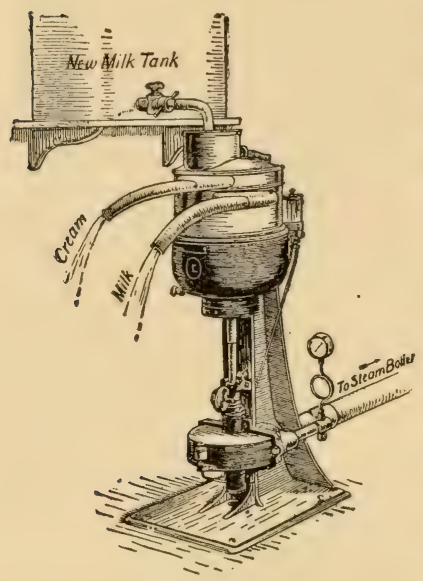

Fig. 111. - Cream Separator people who like fresh butter made in this way, and make all they need, this plan is not bad, especially if they use the skimmed milk and buttermilk for cooking and for drinking.

Making Good Butter. - Good butter such as will keep well can be made with any kind of churn, if only the cream is kept at 60 to 70 degrees, Fahrenheit, during the operation; that is, at about the temperature of fresh well water in the Gulf States. Churning must cease as soon as the butter appears in little particles the size of sorghum seed. These should be strained out, or separated from the milk in some way, and washed and worked enough to get rid of the excess of water and to mix the salt evenly through the product. Of course, in making butter in any thing like a large way, a box or barrel churn becomes necessary, instead of the old dasher churn.

Cream Separator. - The farmer who has four or five good cows and expects to sell butter will find that a hand- 
power cream separator is essential to the best profits. The separator gets practically all the cream from fresh, sweet milk. This cream can be kept at a suitable temperature much easier than can milk when set for cream, and it will generally produce better butter.

A dairyman can well afford to buy ice in summer when he handles only the cream. The fresh skimmed milk is much better than clabber to feed to calves. If a good cow produces $\$ 60.00$ worth of butter a year when the milk is run through a separator, she would not likely make over $\$ 45.00$ worth when the milk is set in the old way. 'Then the saving in labor, in value of skimmed milk, etc., may easily make a saving in profit for each cow of $\$ 20$ a year. The saving on two or three cows, then, may easily pay for a small separator. The same rules alrearly given for churning apply to churning on a large scale. Dairymen who make butter for sale easily learn suitable ways of packing and presenting it to the trade in attractive form.

Breed, not Feed, makes Rich Milk. - It is not true, as many people believe, that rich feed given a cow will produce richer milk than poor food does. Rich feed and plenty of it will produce more milk, but it will be no richer than that given by the same cow when she is eating the poorest feed. Different types or breeds of cattle give milk differing in richness, and different individuals of the same breed give milk differing in quality. Generally Jerseys and Guernseys give milk rich enough to make half a pound of butter from each gallon. Shorthorns, IIolsteins, and Ayrshires give milk requiring about 
three gallons or more to the pound of butter. C'ows give poorest milk soon after bringing calves, a time when they are giving most milk. As their calves grow older, they give less, but richer milk. Milk rich in butter fat is generally rich in casein, or cheesy matter, but not always so. Milk will make twice as much cheese as it will butter. Milk has about the same amount of casein as it has fat, and good cheese contains the casein and the fat. Cheesemaking is more diffienlt in the Sonth than butter-making.

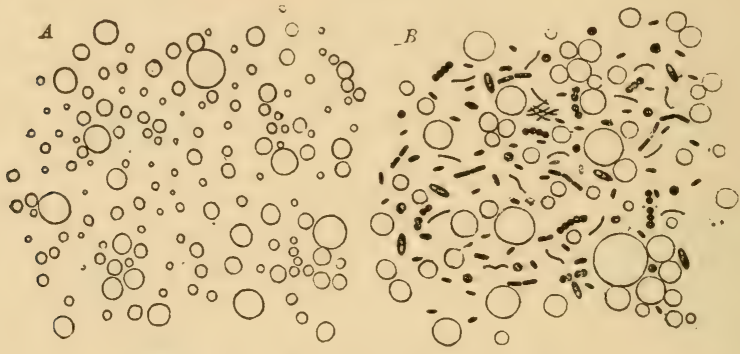

Fig. 112. - Pure and Iipure Milk

A. Fat globules

$B$. Fat globules mixed with germs

Milk also has about as much sugar as it has fat, hut the sugar is not found in either butter or cheese. It remains in the whey, or watery part of the milk. New milk is about eighty-five to eighty-eight per cent water.

Bacteria in Milk. - Milk sours and clabbers because bacteria get into it, and turn the milk sugar into an acid, called lactic acid. Vinegar is acetic acid. Try pouring some vinegar in sweet milk. If sweet milk is heated to about 160 degrees, most of the bacteria will be killed, and the milk will remain sweet longer. This much heat will 
not affect the taste of the milk. However, more bacteria soon get into it, multiply, and cause it to sour later. All vessels that milk is kept in should be scalded, and allowed to sun on the inside. Heat and sunlight kill germs. I)irty, poorly scalded milk vessels cause milk to sour quickly, because the germs are not killed, and a big crop of them starts to multiplying in the milk at once.

\section{Creameries or Factories.}

- In some communities men put up butter, cheese, or condensing factories,

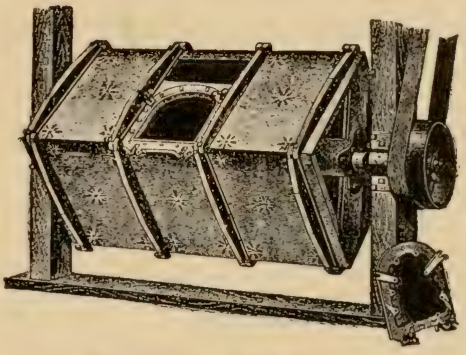

Fig. 113. - Box Chure and buy milk. In other communities farmers unite in putting up creameries. All of them take their milk to the creamery, and after it is manufactured and the expenses are paid, each one gets his share of the profits. Most communities in the South have thus far not produced milk enough for large creameries. With a hand separator and some other simple apparatus, any farmer can make good butter and be independent of creameries.

Visit a Good Dairy. - Suppose you visit some neighbor who is in the dairy business and get him to tell you and show you more about the business. Then if you will feed the cows better, and learn to make good butter and more of it than formerly, you can sell some and make a nice little sum of money. And if you will feed the skimmed milk not needed for other purposes to your pigs, with other foods, they will make money for you. 
Write your Experiment Station for bulletins on dairying. It would require several books the size of this one to tell you all the useful things known about the subject.

\section{QUESTIONS}

What two lines of business are combined in dairying? What are the elements of success in dairying? What are the different products made from milk? Are pure cattle necessary for success? What are grade cattle? Are native cattle used successfully? In what sections are the people backward about this line of business? How are cows and calves managed where only two or three cows are milked? What changes must be made where more cows are kept? IIow must dairy calves be raised? How do most people handle milk and make butter for their own use? Would butter made in this way keep and sell well? Give the advantages of a cream separator. What extra profits can be made on each cow by means of a separator? Does rich feed make rich milk? What influences richness of milk? What breeds of cattle produce richest milk? Will a cow give richer milk when her calf is young or when it is old? How much butter will a gallon of milk make? How much cheese will a gallon of milk make? What causes milk to sour? What effect has vinegar on sweet milk? What sort of factories do people have for handling large amounts of milk? Are creameries necessary for good results?

Experiment. - Put some fresh milk in poorly cleaned pans, some more in thoroughly cleaned pans, and heat some more milk to 160 degrees Fahrenheit, and observe how long each lot will keep before clabbering. Get a dairy thermometer and practice making some good butter at home. 


\title{
APPENDIX
}

IMIPORTANT ECONOMIC FAMILIES OF PLANTS

\author{
By H. Ness, of Texas A. \& M. College
}

THE whole vegetable kingdom is divided into numerous groups and sub-groups, and these are so related that they can be arranged in a continuous series from the lowest to the highest. Indeed, the relationship, as revealed by their structure, is so close that in a great number of cases the neigh boring groups pass imperceptibly into each other, their limiting characters being, so to speak, blended.

The first and main division of the vegetable kingdom is divided into sub-kingdoms. The lower one, or the spore-bearer's, reproduce themselves by spores, small one-celled particles, having no embryo, as, for example, the ferns, mosses, ank numerous much lower plants. The second and higher are the seed-bearers, which reproduce themselves by a seed that contains an embryo, or an infant plant, with enough food inclosed with it to nourish it until it is strong enough to procure its own nourishment.

The seed-bearers are again divided into two groups: 1st, the naked seeded, or those which bear their seed inclosed between scales which spread apart to drop the seeds when they are ripe, as in the pines; $2 d$, those which have their seed inclosed in a pod (cotton, peas, etc.), or fleshy coat (tomatoes, grapes), or two coats, an outer fleshy, and an inner stony (peach, plum, etc.), or a close-fitting, fibrous coat (corn, wheat, oats, and other grasses). This second group is again divided 
into two groups according to the nature of the embryo: namely, those with the embryo having one leaf, or seed-leaf, as onion, srasses, grains, banana, etc. ; and those having two seed-leares, as all the trees, cabbage, tomato, and most garden vegetables.

The following scheme shows the relationship of these principal groups of plants, beginning with the lowest: -

I. Spore-bearers. One-celled living particle having no embryo.

II. Seed-bearers. $\quad\left\{\begin{array}{l}1 . \text { Naked seeded, seed inclosed between scales. } \\ 2 . \text { Vessel seeded, seed inclosed in a vessel. }\end{array}\right.$

$\left\{\begin{array}{c}\int^{a}\left\{\begin{array}{l}\text { One-leaved seeded, with wood and bast in united } \\ \text { strings, surrounded by pith, parallel-veined } \\ \text { leaves, and numerous roots of equal size from } \\ \text { the lower joints of the stem; as in the stems } \\ \text { of corn, sorghum, and numerous grasses. }\end{array}\right. \\ b\left\{\begin{array}{c}\text { Two-leaved seeded, with true bark surrounding } \\ \text { the wood, and with the pith in the center, net- } \\ \text { ted-veined leaves, and true taproot bearing } \\ \text { lateral roots. Examples, cotton, oak trees, etc. }\end{array}\right.\end{array}\right.$

From the two last groups, a, called the Monocotyledons, and b, called the Dicotyledors, come practically all the plants that furnish us with grains, vegetables, and fruits for our living, and fibers for our clothing. 'These groups are again subdivided into orders and families. We will now proceed to name a few of the most useful families and the most useful plants under each, beginning with the Monocotyledons, or the one-leaved seeded.

The Grass Family. - To this belong, as the name indicates, all the true grasses, which also include Indian corn, wheat, rye, oats, barley, and rice, as well as sorghum and sugar cane. This is by far the most important of all families of plants, since it furnishes not only all breadstuffs for our own sustenance, but also grazing and fodder for our domestic animals. From this family the Japanese and Chinese obtain the bamboo, which grows in their countries to be 80 to 100 feet 
high, and furnishes timber for most of their houses. Indian corm is thought to be a native of Mexico, (entral, and South America, where its nearest relatives now grow wild, but the Indian corn, in the highly developed form in which we to-day possess it, has never been found wild by white man. Since the discovery of America, its cultivation has spread among all people living in the warmer parts of the temperate and tropical zones, even among the savages in the interior of Africa.

Palm Family. - This family belongs to the tropics and warm, very often dry, countries of the temperate zones, as North Africa and Arabia, whence we get the date fruit, which we have now commenced to cultivate in the southwestern portion of Texas, near the Gulf and the Mexican borders. From this family we also obtain the cocoanut, which grows throughout the Pacific islands, including the Philippines.

Lily Family. - From this family we get our onions and garlics. which are natives of the Mediterranean countries, and have been cultivated from the earliest antiquity.

The Asparagus Family gives us asparagus, a perennial with numerous horizontal root stocks, which, when on highly fertilized soil, send up early in the spring numerous fast-growing, fleshy shoots that are cut when about six inches high, and much prized as a vegetable diet. The plant, being a native of seacoasts, requires in addition to other fertilizers a bountiful supply of salt.

Banana Family. - The banana is a native of the moist regions of the tropics, but can also be grown in sheltered positions on the Gulf coast. It includes the abaca, or Manila hemp plant, which furnishes the best rope fiber in the world.

\section{DICOTYLEDONS}

Walnut Family.-The pecan, hickory, and English walnut come from this family. The English walnut is a native of Middle and Southern Europe, is suceessfully cultivated in 
California, and will grow well in Texas. It is a nut of the greatest commercial importance. The pecan is native of a large part of the United States, but produces the finest nuts in 'Texas, west of the meridian of Austin. Many cultivated varieties with thin-shelled, very large fruit are now coming into cultivation.

Mulberry Family. - This family gives us a great number of useful trees. From our cultivated fig we have the well-known fruit, which is a hollow head bearing its numerous small flowers in the cavity. Other wild tropical figs give us rubber from the juice of their trunks.

Goosefoot Family gives us the spinach which is grown in our gardens for greens and salad, the common beet, the sugar beet from which much of our sugar is made, and the huge mangel wurzel, raised for cattle food.

Mustard Family. - To this family belong the greater number of our most important vegetables, such as mustard, radish, turnip, cress, and cabbage. As all of them are natives of cool, damp climates, they are grown by us as early spring or late fall crops. The cabbage is a native of the coast of France and other neighboring coasts, where it is yet found in a wild state, having the appearance of our kale. The original wild plant is called Brassica oleracea by the botanists, and has by "sporting" in cultivation given rise to the following forms which come true from seed: the common cabbage in all its forms, in which the stem and the leaves have been converted into an immense bud; the cauliflower, in which the stem has been converted into a cockscomb-like body, called the "flower"; the Brussels sprout, that produces several heads the size of a man's fist as buds in the axils of the leaves along the stem; ruta baga, in which the root has become turnip-like; the kollrabi, in which the short stem has become fleshy and is the edible part; and finally, the kale and collard.

Mallow Family. - From this we get the cotton and the okra. 
Orange Family gives us the oranges and the lemons. Fardy varieties of these fruits are now being cultivated in our coast country on a commercial scale, and still hardier ones are being developed by crossing the tender orange with the hardy trifoliata lemon. The resulting hybrid is called the Citrange, which produces a valuable fruit, and can be grown three to four hundred miles north of the present orange belt.

Grape Family gives us all the grapes, which run into numerous forms both wild and in cultivation. The future grape region of Texas is the arid region west of the Pecos, where these plants will be much freer from diseases than in the moister regions.

Rose Family. - This family used to include most of the orchard and garden fruits. It is now divided into: Pome Family, including the apple, pear, and quince; Rose Family, including blackberry, dewberry, raspberry, and strawberry; Prune Fumily, including peach, plum, cherry, and almond.

Pea Family includes the peas, beans, and numerous forage plants having the pea-like flower, such as clovers and alfalfa.

Cucumber Family includes cueumber and the melons, all constituting valuable commercial crops in our State.

Parsley Family. - From this we obtain several vegetables more useful because of their flavor than the amount of nourishment that they furnish. The principal ones are carrot, parsnip, parsley, earaway, and celery. The last is imported in large quantities from the North, but can be raised with ease in our own State on rich, well-eultivated land. As young plants are slow in coming up and are at first delicate, they have to be started in seed beds. To insure good flavor and crispness, the stems of the leaves are covered by filling up the dirt around them as they grow.

Nightshade Family. - This family gives us the Irish potuto, the eggplant, tomato, the sweet pepper, Cayenne pepper, and tobacco: all American plants and unknown before the discovery by Columbus. The Irish potato is the most widely used vege- 
table in the world. This and the tomato form the most important exportation of garden-truck crops from our State.

Morning Glory Family gives us the sweet potato, which is a native of India, and was cultivated in very ancient tines.

Olive Family gives us the olive, famous for the oil, which is pressed from the plum-like fruit. The olive is native of the Ierditerranean countries, but is now being cultivated in Southwestern 'Texas, Arizona, and California.

\section{TREATMENT OE PLANT DISEASES}

\section{By H. Ness}

Remedies against plant diseases are among the things that belong to our own generation; perhaps because it is within recent times that such immense plantings have been made as to furnish abode for the parasites that produce the diseases on the higher plants.

$\Delta$ fter trials with numerous materials for the purpose of discovering something that would act as poison to the parasitie fungi but be harmless to the host plant, there was at last formd in the salts of copper, especially bluestoue or copper sulphate, a substance that would kill all the fung with which it came in contact without injury to the host. The method of applying this was first started in France, in the district of Bordeanx, as a remedy against downy mildew on grapes. But since most of the fungi live inside in the tissues of their hosts, rery few diseases can be cured. The action of the bluestone is, therefore, rather that of a preventive than a cure. As a preventive it is used in the well-known mixture called Bordeaux mixture, consisting of four pounds of lime mixed with six pounds of bluestone, or copper sulphate, and dissolved in forty-five gallons of water.

This mixture is applied to the plant with a spray pump, throwing the liquid into a steam-like spray and covering the 
entire plant, so that the spores of the fungi find no uncoverert spot for lodging and germinating. It is claimed that the (o)pper salt, instead of injuring the plant, actually stimulates its growth. Spraying must be clone as often as the rain washes the coating off the plants.

To Bordeaux mixture may be alded small quantities of I,ondon purple or Paris green. These substances contain arsenice, which will kill any insect that may eat the leaves or bark of the plant. Only small amounts of these materials can ix+ added, as they are also poisonous to the plant itself and easily cause scorching of the leaves. Lime is used with bluestone? to make the mixture stick to the plant.

Another formula, not so much used, but recommended bescause it sticks well to the plant, consists of a compound (of (o) (1)per and vinegar, called copper acetate, two to four ounces of this being dissolved in twenty-five gallons of water and applied as above.

Numerous other salts of copper are used in these spray solntions; as, for example, copper earbonate, of which three ounces are used in connection with one pound of ammonium carbonate in forty to forty-five gallons of water. To all of these formulas: very small quantities of arsenious salts may be added to kill any insects that may chance to feed on the plants. But in all cases it is the copper salt that kills the fungi or prevents their spores from getting a foothold.

All these spray solutions containing copper salts are used for all contagious diseases affecting the parts of plants above the ground, because they are all due to fungi, which propagate themselves by similar spores carried by air or insects and lodge and germinate on the surface of the host plant before making their entrance into its tissues. 


\section{FIGHTING INSECT ENEMIES - INSECT POISONS}

\section{OR INSECTICIDES}

By C. E. Sanbori, Texas Experiment Station

Below are given formula for making seventeen of the most effective insect poisons known at this time:-

\section{Arsenate of Lead}

Acetate of lead

Arsenate of soda Water

\section{Paris Green Liquid Spray}

Paris green

Lime (fresh unslacked) Water

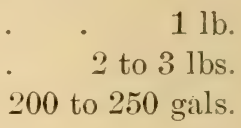

$1 \mathrm{lb}$.

$11 \mathrm{oz}$. $4 \mathrm{oz}$. 50 gals.

\section{Paris Green Dry}

Mix with 25 parts air slacked lime; used pure to kill insects crossing weed patches or feeding on other plants of no value.

\section{Lime Sulphur Wash}

Lime (fresh unslacked) Sulphur IVater

\section{Kerosene Emulsion}

Hard soap .

Water

Kerosene
$20 \mathrm{lbs}$. 16 lbs. 50 gals.

๙. For a $5 \%$ solution, dilute with 37 gals. water.

b. For a $15 \%$ solution, dilute with $10 \frac{1}{3}$ gals. water.

c. For a $20 \%$ solution, dilute with 7 gals. water. 


\section{Whale Oil Soap}

1 lb. to 2 gals. water.

\section{For a Wixter Spray for Evergreens}

Resin, pulverized

Caustic soda, granulated, $98 \%$

Fish oil

Water for final bulk .
20 lbs. $4 \frac{1}{4}$ lbs.

3 pts. . 150 gals.

\section{For a Summer Spray}

1 qt. flowers of sulphur dissolved by boiling with 10 lbs. potash soap in 15 gals. of water. To use, dilute with 35 gals. of water.

\section{Bordeaux Mixture}

If this spray is being used where biting insects are injurions, its purpose may be doubled by adding the arsenical as given :Copper sulphate Lime (fresh unslackerl) Water Acetate of lead . Arsenate of soda

\section{Carbon Bisulphide}

2 to $4 \mathrm{lbs}$. to $1000 \mathrm{cu}$. $\mathrm{ft}$. of space. Set in vessels and allow to evaporate. Gas will sink through grain and smother weevils.

\section{Before Insects appear in the Spring}

Trees should be bandaged from a few inches below surface of soil to two feet above with newspapers or other convenient material. Remove and burn bandages after hibernation of insects. 
XII. Inject kerosene into the tumnels.

XII. Kill larve in tumnel with a wire or in some calses ent the larvæ out.

XIV. a. After harvest destroy its food plants and allow no hibermating places to exist except as traps for burning.

b. ('ontrol by infecting with parasites or contagious diseases.

c. Destroy infested fruit.

d. Cultivate the soil two or three inches in depth.

\section{Sulphur as a Dry Spray}

Apply with a dust sprayer or shake it through a canvas hag.

\section{XTI. POISOXEN BatT}

Paris green or white arsenic . . . . . $40 z$. Bran

Molasses or thick sugar-water . . . . . 1 pint Water, enoughi to make a soft dough.

XVII. Spray premises or dip animal in two per cent solntion of zenolium.

\section{LAST OF HARHFUL INSECTS AND REMEDIEN}

Following is a list of the worst insect pests, and the best means now known of fighting them. The insecticides are referred to by numbers from I up to XVII, given above.

Angular winged katydid (Microcentimm retineris, Burm.). I, II, III, or IX.

Angumois grain moth (Sitotionfa rereclella, L.). X.

Ants (different speries). X (pour in their nests).

Apple curculio (Anthonomus gradrigiblus, Sar). I or II.

Apple tree aphis (different green species). T, l, immediately before leaves fall.

Army worms (Spring) = Lenceniue mipuncte, Haw.; (Fall) $=$ Laphygma fingiperda, A. \& S. III. 
Bag worm (Thyridopteryx spp.?). Hand pick bags.

Boll worm (Heliothis obsoleta, Fab.). Fall and winter plowing. Bean and pea weevils. X.

- Red bug (Klinophilos lectuluriu, L.). Spray with gasoline.

Blister beetles (different species). III, or spray colonies with gasoline.

Blister beetles of plum (Pemphoprea Texana, Lee.). Destroy mechanically.

Cabbage aphis (Aphis bressice, T.). V, a or b, VI.

Cabbage maggot (Pegomyia lnoussiru, Bonché). Apply tobacco dust as a preventive.

Cabbage worm (Pontia rape, L.). I, II, or III.

Chicken lice and mites. Spray premises with zenolium and apply kerosene to roosts; provide dust baths for fowls.

Chinch bug (Blissus leucopterus, Say). XIV, a or h).

Citrus white fly (Aleyrodes citri, Riley \& Howard). TII or VIII.

Codling moth (Carpocapsa pomonella, L.). II.

Colorado potato beetle (Lepinotursa decem-lineuta. Aay.). I or III.

Corn ear-worm (IIeliothus obsoletr, Fab.). Fall or winter plowing.

Cut worms (many species). XVI.

False chinch bug (Nysirs angustutus, Uhl.). T, $a$ or $b$.

Flat headed apple tree borer (Chrysobothris femoruta, Fab.). XIII.

Fleas (different species). Remove all dust and rubbish; clean floors and sprinkle with kerosene: keep out dogs and cats: scatter pyrethrum powder under carpets and in kemnels.

Glover's scale (Lepidosaphes gloverii, Pack.). V'II or VIII.

Grain beetles (different species). X.

Grasshoppers (different species). I, II, or III.

Green bug (Toxoptera graminum, Rond.). See page 155.

Harlequin cabbage bug (Murgantia histrionica, Hahn). VI or $\mathrm{V}, b$. 
Hemispherical scale (Lecunimm hemisphericum, Targ.). TII or VIII.

Hessian fly (Mayetiola destructor, Say.). XV, ", and late sowing of wheat.

May beetles (Lachustemu, sereral species). I, also pasture infested grass land with hogs.

Melon aphis (Aphis gossynii, (ilor.). X $\mathrm{T}^{2}$ and $\mathrm{V}$,

Mexican cotton boll weeril (.1. grumlis, Boh.). See page 132.

Mosquitoes (different species). Destroy larva by pouring kerosene on water where eggs or larve are. Cover cisterns, empty troughs, cans, and useless vessels of all kinds. Wratch for stagnant pools of water and drain them. Put fish in permanent pools and tanks.

Oyster shell bark louse of the apple (Lepridosaphes pomorm, Bonché). IV.

Peach scale (Aulacaspis pentagona, Targ.). IV.

Peach tree borers (Suminoirlen exitiosu, Say, and Synanthedon pictipes, Say). XII, XIV.

Plum curculio (Comotrachelus nempliar, Hbst.). Jar trees in early morning, collect and destroy beetles.

Purple scale (Lepidosaphes citricola, Pack.). VII, VIII, winter spray on deciduous trees, IV.

Red spirlers or mites (different species). XVI, XVII.

Round headed apple tree borer (Soprerdu candida, Fab.). XIII, XIV, XII.

S'an José scale (Aspidiotus perniriosus, Comst.). IV.

Scurfy scale (Chisonaspis furfura, F.). IV.

Soft scale (Lecanium hesperidum, L.).

Southern plum aphis (Aphis setarice, Thos.). T, b, immediately before leaves fall or before buds open and after eggs hatch.

Striperl cucumber beetle (Dialnotica vittata, Fab.).

Sweet potato weevil (Cylas formicums, Fab.). X.

Tent aterpillar, The American (Ifulucosoma Americana, 
Fab.). When tents first appear cut off branches to which they are attached and burn.

Tomato worm (Pllegethontins sexta, L.). Hand pick and destroy.

Twig girdler (Oncideres sp.?). Burn amputated twigs.

Woolly aphis (Schizonemralenigera, Hausm.). V', l.

Footsote. Following are the names, with their abbreviations, as used after the technical names of insects herein treated: A. \& S., Abbott ¿. Sulthith; Boh., Boheman; Bouché, Bouché; Burm., Burneister; Comst., Comstock; F., Fitch ; Fab., Fabricius; Glor., Glover; Harr., Harris; Hausm., Hausmann; Hahn, Hahn; Haw., Haworth ; Hbst., Herbst ; Howard, Howard ; Lee.. Leennte; L., Linneus ; Pack., Packard ; Riley, Riley; Ront., Rondani; Say, Say ; Targ., Targoni; Thos., Thomas; Uhl., Uhler; Walsh, Walsh. 


\section{JUDGING STOCK - TEXAS A. \& M. COLLEGE}

Draft Iorse - Scale of Points - For Gelding.

\section{1. $\mathrm{AGE}$}

\section{General Appearance :}

2. HeIGHT .

3. Weight, over $1500 \mathrm{lbs}$. . . score according to age

4. Form, broad, massive, low set, proportioned

5. Qualitr, bone clean, yet indicating sufficient substance'; tendons distinct, skin and hair fine

6. Temperament, energetic, good disposition

\section{Head and Neck:}

7. Head, lean, medium size

8. Muzzle, fine; nostrils large ; lips thin, even .

9. Eyes, full, bright, clear, large

10. Forenead, broad, full

11. EARs, medium size, well carried

12. Neck, muscled; crest high ; throatlatch fine; windpipe large

\section{Forequarters :}

13. Shovtones, sloping, smooth, suug, extending into back

14. Aru, short, thrown forward

15. Foreary, heavily muscled, long, wide .

16. Kxws, ivide, clean eut, straight, deep, strongly supported .

17. Cansoss, short, lean, wide; sinews large, set back

18. Fетцоскs, wide, straight, strong

19. Pasterns, sloping, lengthy, strong .

20. FeEr, large, even size, straight; horn dense, dark color ; sole concave ; bars strong; frog large, elastic ; heel wide, high, one-half length of toe

21. Legs, viewed in front, a perpendicular line from the point of the shoulder should fall upon the center of the knee, cannon, pastern, and foot. From the side, a perpendicular line dropping from the center of the elbow joint should fall upon the center of the knee and pastern joints and back of hoof 


\section{JUDGING S'TOCK - Continued}

\begin{tabular}{l} 
Draft Horge-Scale of Polxts-For Gelding \\
\hline
\end{tabular}

Perfect

SCORE

Brovgit Forwari

\section{Body :}

22. Cirest, deep, wide, low, large girth

2:3. R.ris, long, close, sprung

24. BACK, straight, short, broad

25. Lors, wide, short, thick, straight

26. UNDERLINE, flank low

\section{Hindquarters :}

27. Hips, smooth, wide

28. Crovp, long, wide, muscular .

29. TAlL, attached high, well carried .

30. Thigns, muscular

31. Quarters, deep, heavily muscled

32. Gaskins or Lower THugns, wide, muscled

33. Носкs, clean cut, wide, straight

34. Cinnoxs, short, wide ; sinews large, set back

35. Fetrocks, wide, straight, strong

36. Pasterss, sloping, strong, lengthy

37. FeEt, large, even size, straight; horn dense, dark color ; sole concave; bars strong; frog large, elastic; heel wicle, high, one-half length of toe

:S. Legs, viewed from behind, a perpendicular line from the point of the buttock should fall upon the center of the hock, cannon, pastern, and foot. From the side, a perpendicular line from the hip joint should fall upon the center of the foot and divide the gaskin in the middle; and a perpendicular line from the point of the buttock should rum parallel with the line of the camnon Action : 39. W A LK, smooth, quick, loug, balanced . . . . . 6 40. Твот, rapid, straight, regular . 
1. AGE

General Appearance :

2. Weight .

3. Heigin .

4. Form, symmetrical, smooth, stylish

5. Quality, bone clean, fine, yet indicating sufficient substance; tendons defined; hair and skin fine

6. Temperanent, active, good disposition .

4

Head and Neck:

7. HeAD, lean, straight

8. Muzzle, fine; nostrils large ; lips thin, even .

9. Eres, full, bright, elear, large

10. Foreitead, broad, full

11. EArs, medium size, pointed, well carried, and not far apart

12. Nеск, muscled ; crest high ; throatlatch fine; windpipe large

\section{Forequarters :}

13. Snouners, long, smooth with muscle, oblique, extending into back and muscled at withers

14. ArM, short, thrown forward

15. Forearm, muscled, long, wide

16. Kxwes, clean, wide, straight, deep, strongly supported

17. Cannows, short, wide; sinews large, set back

18. Fetrocks, wide, straight

19. Pasterns, strong; angle with ground, 45 degrees

20. Feet medium, even size, straight; horn dense; frog large, elastic ; bars strong ; sole concave ; heel wide, high

21. LEgs, viewed in front, a perpendicular line from the point of the shoulder should fall upon the center of the knee, cannon, pastern, and foot. From the side, a perpendicular line dropping from the center of the elbow joint should fall upon the center of the knee and pastern joints and back of hoof 
JUDGING STOCK-Continued

\section{Lignt Horse - SeAle of Poists - For Gelding}

PERFECT

SCOIT:

BrovgitT Forward

Body :

22. Cnest, deep, low, large girth

23. RiBs, long, sprung, close

24. BAск, straight, short, broad, muscled

25. Lors, wide, short, thick .

26. UNDERIINE, long, flank let down .

\section{Hindquarters :}

27. Hips, smooth, wide, level

28. Croup, long, wide, muscular.

29. TArt, attached high, well carried

30. 'Thighs, long, muscular, spread, open angled .

31. Quarters, heavily muscled, deep .

32. Gaskins or Lower 'Turus, long, wide, muscular .

33. Hocks, clearly defined, wide, straight

34. CAnnoxs, short, wide; sinews large, set back

35. Fetrocks, wide, straight

36. Pasterns, strong, sloping

37. Feet, mediun, even size, straight; lourn dense; frog large ; elastic ; bars strong; sole concave; heel wide, high

38. Legs, viewed from behind, a perpendicular line from the point of the buttock should fall upon the center of the hock, cannon, pastern, and foot. From the side, a perpendicular line from the hip joint should fall upon the center of the foot and divide the gaskin in the middle; and a perpendicular line from the point of the buttock should run parallel with the line of the cannon

\section{Action :}

39. WALK, elastic, quick, balanced

40. 'Тroт, rapid, straight, regular, high

'Total.
42 


\section{JUDGING STOCK-Continued}

Beff Steer - Scale of Points

P'ERFECT

SCORE

\section{General Appearance :}

1. Weignt, score according to age

2. Fonm, straight top line and underline; deep, broad, low set, stylish

3. Qua ritr, hair fine; skin pliable; dense, clean bone; body covering to be uniform, of a mellow touch, yet sufficiently firm to indicate a large proportion of muscle

4. Conmition, development of flesh and fat; fat indicated by spinal covering, rib covering, fullness of flank, purse and tongue root

Head and Neck:

5. Muzzle, broad; mouth large ; jaw wide; nostrils large .

6. Eres, large, clear, placid

7. FACE, short, quiet expression

8. Forehean, broad, full

9. Ears, medium size, fine texture .

10. Horss, fine texture, oval, medium size

11. NECK, thick, short, throat clean

Forequarters :

12. Siloulder Vein, full .

13. Shotiden, covered with flesh, compact on top, smooth

14. Briske'r, advanced, breast wide

15. DewLAP, skin not too loose, and drooping

16. LEGs, straight, short; arm full; shank fine, smooth.

\section{Body :}

17. Cnest, full, deep, wide; girth large ; crops full

18. RuBs, long, arched, thickly fleshed

19. BACk, broad, straight, smooth, even

20. Lorn, thick, broad

21. Flask, full, even with underline

\section{Hindquarters :}

22. IIIPs, smoothly covered, distance apart in proportion with other parts 


\section{JUDGING STOCK - Continued}

BEFF STEER - SCAJF OF POINTS

Perfect

ScORE

Brought Forward

Hindquarters - Cont. :

2:3. Rumr, long. wide. even, tail head smooth, not patchy

24. Pix Boxls, not prominent, far apart .

25. 'Thisns, full, deep, wide

26. 'I'wist, deep, plump

27. Purse, full, indicating fleshiness

28. Less, straight, short; shank fine, smooth .

'Totil.

\section{General Appearance :}

1. WEIGHT

2. Form, inclined to be wedge-shaperl

$\therefore$ Qralry, hair fine, soft; skin, mellow, loose, medium thickness, secretion yellow; bone, clean, fine

4. Coxmriox, lean, though vigorous appearance when in milk

\section{Head and Neck:}

5. Muzzce, clean cut; mouth large ; nostrils large

6. Eres, large, bright, full, mild

7. FACE, lean, long, quiet expression

8. ForeHE.ID, broad

9. Ears, medium size, yellow inside, fine texture

10. Horss, fine, texture waxy .

11. Nвк , fine, medium length; throat clean. light dewlap

Forequarters :

12. Wrthers, lean, thin

13. Shoutders, light, oblique .

14. LEGS, straight, short; shank fine 


\section{JUDGING STOCK-Continued}

SCALE OF POINTS-For DAIRY COW

P'ERFECT

Scon:

BrougitT Fol:WAli)

\section{Body :}

15. Chest, deep, low ; girth large with full fore flank . . 10

16. Barres, ribs broad, long, wide apart, larga stomach . 10

17. ВАск, lean, straight, open jointed . . . . . 2

18. Lorn, broad . . . . . . . . . . 2

19. Navel, large . . . . . . . . . . . . . 2

\section{Hindquarters :}

20. Hips, far apart, level .

21. Rump, long, wide

22. Pin Bones on Thure, high, wide apart . . . . . 1

23. TAIL, long, slim, fine hair in switch . . . . . . 1

24. THugns, thin, long

25. Eactorneon, sprearling orer thighs, extending high and wide; large thigh ovals .

26. UnnEs, long, attached high and full behind, extending far in front and full, flexible; quarters even and free from fleshiness

27. Teats, large, evenly placed

28. Mamary Verss, large, long, tortuons, branched with double extension; large and numerous milk wells .

29. Legs, straight, short ; shank fine 


\section{STOCK DISEASES AND REMEDIES \\ By Dr. R. P. Marstellar, Texas A. \& M. College}

\section{THE HORSE}

Chronic Indigestion. - The three most common causes of chronic indigestion are improper food and water, had teeth, and the presence of worms in the intestines.

Food and Water. - Animals when given faulty food or water do not "do well," have an unthrifty hair coat, sweat easily, and cannot stand hard work. In such cases it is well to change the feed supply.

Bad Teeth. - Horses have bal teeth. Many of the common defects of teeth can be detected by the ordinary observer, if he will take the trouble to open the animal's mouth and investigate. Common defects are irregular teeth, decayed teeth, teeth with sharp edges. Very often a few dollars spent in having the teeth attended to will prolong the animal's iffe and usefulness.

Worms. - Young horses often have worms in the intestines that sap their vitality. The symptoms are the same as those of poor food and water. A very safe and efficient remedy for this trouble is a drench made of two ounces of turpentine and one pint of linseed oil.

Acute Indigestion: Colic. - If any of the canses of rhronic indigestion are severe and continued, they lead to colic, the symptoms of which are those of chronic indigestion angmenterl. Horses with colic show pain by being restless, getting up and down, looking around at side and pawing and stamping. An ounce of chloral hydrate in one pint of water often gives relief without causing any of the deleterious effects of many other remedies. 
Bad Eyes. - The most common disease of the eyes of horses is " moon blindness." The first attack is mistaken very often for a slight injury. But the animal has from time to time, at more or less regular periods, subsequent attacks, each being more severe and leaving more permanent effects. This is an incurable trouble and results in blindness.

Beards of grains and chaff get in the eyes of animals and will cause serious injuries if not removed. A fairly satisfactory examination can be made by turning the lids outward one at a time. This will in many cases bring to view the foreign body.

Feet. - The old saying, "no foot, no horse," is as true as ever. Bad feet are often due to neglect of the hoofs when the animal was young. If the owner would take the trouble to trim the hoofs this conld be avoided. If this is not done they grow out of shape, forcing the animal to throw too much of his weight on some one joint, tenclon, or ligament, with the result that it becomes inflamed and is permanently injured.

Nail Prick. - Lameness due to this common trouble is often not discovered at all by the layman. The most prominent symptoms besides lameness are swelling of the leg, extending from below upwards, loss of appetite, and fever. A careful examination of the foot will bring to view the foreign body that is causing the trouble. In any care of lameness, it is well to examine the foot thoroughly.

Treatment. - Remove cause of trouble, enlarge opening and fill with carbolic acid or hydrogen peroxide. Keep animal in clean, dry place until it goes sound.

Lung Fever. - Lung fever is characterized by hurried respiration, high temperature $\left(105^{\circ}-107^{\circ} \mathrm{F}\right.$.), nasal discharge of rusty color, "stary" eyes, and loss of appetite. The death rate in this disease is high. Death results in about six or seven days.

Treatment. - There are no specific remedies, and treatment should not be undertaken by laymen. 
Tetanus (Lockjaw). - This is a disease from which all domestic animals may suffer, and most commonly seen in the horse. It is due to a germ which cannot live in the presence? of oxygen. It gains entrance to the animal body throngh punctured wounds or through those in which dirt is gromel into the flesh. The symptoms are a protrusion of the haw from the inner angle of the eye over the ball ; straddling gait, marked muscular rigidity; the tail is carried out, ears are pricked, and nostrils are distended. All of these symptoms become more marked if the animal is irritated in any way.

Treatment. - Keep animal quiet and give soft feed. As a preventive in suspicious wounds, Tetanus antitoxin should be given. This has only a preventive and not a curative power.

Blind Staggers. - Many theories are prevalent in regard to the cause of the epizootic form of this disease. One of the most popular is that it is due to some mold or fungus. Experiments carried out at the Texas Experiment Station tend to disprove this idea. To the careful observer, from all data available at present, it seems to be due to labor diet while resting, for when work stock are used regularly in the spring it disappears.

Symptoms. - The animal will not lead, and refuses to come out of stable. When eating it will stop suddenly with some food protruding from the mouth, remain this way for some time and then start to eat again. Many do not walk straight, and stand with their feet crossed. Some are so badly affected that they do not show any regard for obstacles, and will walk, or try to walk, through fences, stall partitions, etc. A large per cent of animals that have this disease die; some make a partial recovery, and are termed "dummies."

Prevention. - Reduce feed when animal is not working. Give plenty of roughage and exercise.

Glanders. - This is an insidions disease quite hard to diagnose in chronic eases without the use of mallein, a diagnostic 
agent. Loute cases have blook-stained nasal discharge, stallshaped scars in nose, enlargement of glands in the hollow hetween the jaw bones, and an unthrifty condition. In the 'rutaneous form, or farcy, chronic ulcers are formed on the skin.

Treatment. - Incurable. It is unlawful to keep animals affected in this way.

Wounds. - In none of the ailments of animals is cleanliness so essential as in wound treatments. If the best results are to be obtained, wounds must be kept clean and unirritaked. If these conditions are provided, most wounds will heal in a reasonable time, but it is often impossible to prevent the entrance of dirt or pus. To remove these first wash with a two per cent solution of baking soda, then a two to five per cent of carbolic acid, kresol, or chloro-naphtholem, and then sift over the wounds a powder consisting of one part camplior, one part alum, and four parts boracic acid.

\section{CATtLE}

I)iseases of the digestive organs of cattle are very common, due to the fact that these organs are taxed to their limit in both nilk and beef production. The organs often are only overworked and will soon return to their normal conditions if given a rest for a few days. Some of the most common forms of indigestion are :-

Bloat, or hoven, due to a tistension of the paunch with gas, which is caused by fermentation of food.

Treatment. - Ordinarily, baking powder given in doses of four spoonfuls will often relieve the comlition. In some cases it is necessary to puncture the hollow of the Hank on the left sicle, but this had best be done only by those who have had experience.

Scours. - In the South, dairymen have considerable trouble with calf scours. This is caused by feeding milk which has been acted upon by certain bacteria, which are very common 
and active in a warm c:imate. Br putting formalin in the milk (one part formalin to 5000 parts milk) this trouble can be overcome with no serious injury to the stock. Older cattle sometimes have diarrhea, but this cam generally be overcome by regulating the diet.

Constipation. - When cattle run on dry pastures for some time they often become constipated, and if they are not relieved, inflammation and even death will be the result. This can be relieved by giving one pound of epsom salts and one ounce of ginger in one quart of rain water.

Texas Fever. - The symptoms of this clisease are a yellow color of white of eye, red urine, rapicl emaciation, and the presence of many ticks.

As cattle that are very poor camnot withstand this disease, it is well, if practicable, to feed them. Reduce ticks by dipping and rotation of pasture.

Black Leg. - Symptoms. Lameness in one leg, more often hind leg; accompanied by swelling which will crackle when the land is rubbed over it, high temperature, rapid respiration. muscular tremors in later stage.

This is an inculable disease when once developerl. It can be preventerl by vaccination.

Anthrax (Charbon). - While this disease has been reported more often in cattle and sheep, all domestic animals and even man may contract it.

The sudden appearance, the short duration of the disease, the number of animals affected, cause one to detect the disease early in the outbreak. Death is so sullen that in many cases the clinical symptoms are not very pronounced. However, if the disease rums for several days, swellings appear on the various parts of the body, neck, brisket, and abdomen. These swellings are painful, hot, and hard. If incised, they appear to consist of a gelatin-like material.

Trertment. - Incurable; outbreaks are, however, said to be controlled by vaccination. 
Actinomycosis (Lumpy Jaw). - This disease is characterizer? generally by enlargement in the region of the lower jaw. Swelling at first is hard and painful and gradually inerease's in size. Later it breaks in several different places, discharging pus with yellow grain-like particles. The disease often attacks the bone itself, loosening the teeth and making it impossible for the animal to eat.

Seventy per cent of the cases can be cured if treatment is begun early.

Treatment. - Give two drachms of potassium iodide daily for ten days; discontinue and repeat in ten days. If necessary, treat a third time. Human beings may contract this disease by eating meat of infected animals.

Milk Fever. - This disease is associated with ralving, and is characterized by unconscionsness, manifesting itself first hy unsteady gait and crooked neck. Then the animal falls down and may lie stretched out or with head curled around to one side. Pulse and respiration are normal.

This disease is very successfully treated by inflating the udder with carbolized air or oxygen. Unless the person thint treats the animal has some knowledge of antisejsis he will infect the udder and the cow will develop garget.

Garget. - The most common disease of the udder is garget, which is an infection of one or more quarters of the udder. It is caused by the entrance of germs. Pus forms and the milk becomes stringy.

This is a very unsatisfactory disease to treat; even when relieved, it shows a tendency to return. The quarters affected may be irrigated with a solution consisting of one part permanganate of potash to four or five hundred parts water.

Swelling or Inflammation of Udder. - When the cow is fresh, swelling can be controlled by. giving her a pound of salts (epsom) followed by one drachm of fluid extract of bellarlona morning and evening until relieved. 
Bathe the cow's udder with a liniment consisting of four parts lead water and one part laudanum.

\section{DOGS}

Rabies (Madness). - Perhalps there is no disease of domestic: animals that is so much dreaded and feared by people as rabies, or "mad dog." This is largely due to ignorance and the fact that there are many misleading and ungrounded ideas in regrard to it, especially the length of time it takes the disease? to develop. All data and experiments show that the period of: incubation varies from ten to sixty days. Some of the most prominent symptoms are change of voice, change of disposition. abnormal appetite (in post mortem, sticks, old leather, dirt, pte. are often found in the stomach), rapid emaciation, paralysis, ancl leath. In the furious form the animal shows tendency to bite, while in the dumb form, which is the most common, the animal soon becomes paralyzed and shows no tendency to bite.

The conservative thing to do is to quarantine suspicious cases securely. This will give opportunity to observe the animal. If it has rabies it usually dies in the course of ten days. If the animal does not die within this time, it is probably not affected with rabies, and the knowledge of this fact will always give persons that may have been bitten a great content of mincl. As one man remarked who had had some practical experience with rabies, "I would not take one thousand dollars for a dog" that had bitten me. I would keep him and see for myself if he developed the disease."

Persons that have been bitten by a rabid animal should take Pasteur treatment immediately. 



\section{GLOSSARY}

A

Abdomen. The belly of an animal or hindmost part of an insect.

Acid. A sour chemical compound.

Acid phosphate. A fertilizing material made by mixing sulphuric acid with ground bone or ground phosphate rock.

Alkali land. Land having salts hurtful to crops.

Aluminum. A white metal in clay, often separated and used in the arts.

Ammonia. A compound of nitrogen and hydrogen.

Ammonium Carbonate. A compound of ammonia and carbonic acid gas.

Analyze. To separate into elements and find the composition of.

Annual Plant. A plant that dies root and top the first year of its life. Antagonistic. Opposed.

Anthrax. An animal disease, also called charbon.

Available. Capable of being used.

B

Biennial Plant. A plant living two years and making seed the second year.

Bisulphide of Carbon. A compound of carbon and sulphur called "high-life," used to kill weevils in grain.

Blight. A withering and drying up of plant leaves.

Bluestone. A compound of copper and sulphuric acid.

Bordeaux Mixture. A mixture of bluestone, lime, and water for spraying.

Botany. A science describing plants.

\section{C}

Calcareous. Composed largely of calcium, or lime.

Calcium. The metal which, united with oxygen, makes lime.

Cannon. The bone of the lower leg of the horse.

Capillary. Composed of little tubes or pores.

Carabao. Filipino name for the water buffalo.

Carbon. The main constituent of coal, charcoal, diamonds, and wood.

Carcass. The dead body of an animal.

Casein. The part of the solids of milk containing nitrogen, and the main part of cheese.

Caterpillar. A young insect. 
Chemical Change. A very complete change caused by elements uniting or separating from each other.

Chlorine. A gas not found pure in nature, but which when united with the metal sodium forms salt.

Citrus Fruits. Acid fruits like oranges, lemons, and grape fruits. Commercial Fertilizer. A fertilizer bought and sold and shipper.

Complete Fertilizer. A fertilizer containing nitrogen, phosphoric acid, and potash.

Compound. A substance made up of two or more elements.

Concentrated. Strong or condensed.

Concentrates. Rich feeds like meal, oil cakes, or grains.

Contagious. Liable to spread.

Copper Acetate. A compound of copper and vinegar.

Cretaceous. Consisting of chalk, or lime rock.

Crossing. Mixing two varieties of plants or two breeds of animal:

Croup. Top of a horse's hips.

Crystallize. To form crystals, or grains, like sugar.

\section{D}

Dicotyledons. Plants having two seed leaves.

Disseminated. Scattered ah ut.

Dodder. A parasite, growing on alfalfa and other plant..

Dormant. Sleeping.

Dual-purpose. For two purposes.

\section{$\mathrm{E}$}

Element. The simplest form of matter, as iron or gold.

Ensilage. Green feed kept in a silo, or air-tight room or pit.

Escutcheon. The back part of udder and thighs of milk cows, where the hair turns up instead of down.

Evaporate. To pass off in the air.

Expand. To grow larger.

\section{F}

Ferment. To sour, or change on account of ferments, or bacteria. Fertility. Being fertile or fruitful.

Fertilizing Elements. Phosphoric acid, nitrogen, and potash.

Floats. Ground phosphate rock.

Formalin. A substance used to kill spores or fungi.

Formula. A preseription or direction for making mixtures.

Fungi. Little plants that can be seen only with a microseope.

Fungicide. Something to kill fungi.

Fungous Diseases. Diseases caused by fungi.

G

Geology. The science which describes the rocks of the earth and the changes they have gone through.

Germinate. To sprout.

Germs. Small living beings that can be seen only with a microscope. 
Glacier. A moving body of ice.

Glucose. A kind of sugar that will not form grains, or crystals.

Gypsum. Lind-plaster, a compound of lime and sulphuric acid.

$\mathrm{H}$

Hibernate. To live over winter.

Hock. Part of the hind leg of a horse.

Host. Plant another plant or insect feeds on.

Humid. Having natural supply of water.

Humus. The partly rotted leaves, roots, and stems of plants existing in the soil.

Hybridizing. The mixing or crossing of plants or animals of different species.

Hydrogen. The lightest gas known, and one of the elements of water.

Hygroscopic. A term used to describe the water existing in substances supposed to be dry.

\section{I}

Infected. A plant or animal is infected when germs or spores of disease enter it.

Inoculation. The act of inoculating or vaccinating with germs.

Insect. An animal having six legs and having its body divided into three parts.

Insecticide. Insect poisons.

Inverted. Changed, as from crystal sugar to sticky, gummy sugar.

Irrigation. Artificially supplying water to land.

Isolate. To separate from others.

\section{K}

Kerosene Emulsion. A spraying mixture of soap, water, and kerosene oil.

$\mathbf{L}$

Lactic Acid. Acid formed from milk sugar.

Larva. The grub of insects.

Layering. Making limbs of plants take root, and then transplanting.

Legumes. Plants bearing pods.

Lespedeza. Japan clover.

Lichens. Low moss-like plants growing on rocks or wood.

Lister. A plow having a double moldboard and throwing dirt both ways.

Loam. A mixture of sand and clay.

\section{M}

Magnesium. A chemical element existing in all soils in combination with other elements.

Magnify. To make large in appearance by means of a microscope. 
Mammary Veins. Milk veins of a cow just forward from the udder. Manganese. A metal somewhat like iron - an element.

Mechanical Change. Any change in a substance not as complete as a chemical change.

Membranes. Thin walls or divisions.

Microscope. An instrument for making things look large.

Monocotyledons. Plants having one seed leaf.

Mulch. A cover of leaves, straw, or fine earth for the land.

Muriate of Potash. A compound of potash and chlorine containing 50 per cent of potash, and used as a fertilizer.

\section{$\mathrm{N}$}

Nitrate of Soda. A readily soluble compound containing nitrogen.

Nitrogen. A chemical clement composing about four-fifths of the air.

Nodule. See Tubercle.

Nutrients. The parts of feed stuff that may nourish the animal.

\section{O}

Organic Matter. Any material that was formed from living beings, such as plants and animals.

Osmosis. The mixing of liquids of different strengths through membranes, or cell walls.

Oxygen. The gas composing about one-fifth of the air and neessiry for breathing.

$\mathrm{P}$

Parasite. A plant or animal living on another plant or animal.

Pasterns. Part of a horse's fore leg between the hoof and the joint above.

Perennial Plant. A plant living more than two years.

Phosphorus. The metal which forms phosphoric acid when combined with oxygen.

Physical Change. Se Mechanical Change.

Pistil. The part of the flower making the secd.

Pollen. The dust on the stamens of a flower that fertilimes the seed.

Pollenized. Fertilized with pollen.

Porous. Having pores; being open.

Potassium. The metal which, combined with oxygen, makes potash.

Prolificness. Bearing abundantly.

Propagate. To multiply by planting, transplanting, etc.

Protein. The constituent of food containing nitrogen.

Pruning. Cutting trees back, or trimming.

Pulverize. To crumble and make fine.

Quarantine. To keep within certain limits. 
$\mathrm{R}$

Rabies. Madness, as in dogs.

Reservoir. A storage pond for water.

Rotation. A certain round, or order, for instance of crops.

Roughage. Coarse feed such as hay, straw, or cotton-seed hulls; also called "roughness."

\section{S}

Sanitary. Cleanly; conducive to health.

Scion. The part of a plant inserted in a stock in grafting.

Sedentary. Remaining in place.

Shredding. Tearing into fine particles.

Silicon. The metal largely composing sand.

Silo. A pit or building for preserving green feed.

Sodium. The metal forming soda when combined with oxygen.

Soiling. Growing green crops and cutting and feeding to animals.

Soluble. Dissolving in water.

Special-purpose. For one purpose.

Species. A group of plants or animals rather closely related.

Spores. Seeds of fungi.

Sport. A plant or animal quite different from its ancestors.

Spraying. Sprinkling or forcing liquids in a fine spray over plints.

Stamens. The parts of flowers furnishing pollen to fertilize the pistils.

Sterilize. To kill germs, generally by heat.

Stock. Plant into which another plant is grafted or budded.

Stomata. Pores or holes in plant leares that take in air and give off water.

Stover. Dried eorn stalks after the grain has been removed.

Subsoil. Part of soil under the top soil.

Succulent. Green; containing much water.

Sucrose. Grain or crystal sugar.

Sulphate of Potash. A compound of potash and sulphuric acid containing 50 per cent of potash.

Superphosphate. Acid phosphate.

Terracing. Leveling land in a way to prevent washing.

Tetanus. A disease called lockjaw.

Thermometer. Instrument for measuring temperature.

Thorax. That part between the head and abdomen.

Tillage. Working the land.

Transplanting. Taking up and setting out plants again.

Transported. Moved from original place.

Trifolium. Having three little leares on one stem.

Tubercle. A wart or knot or nodule on roots of leguminous plants.

Udder. The milk organs to which the teats are attached. 
Veterinary Science. The science teaching the prevention and cure of diseases of animals.

Vitality. Strength to germinate and grow.

Vulture. A buzzard, or carrion crow.

\section{W}

Water Table. The level of standing water in the soil.

Withers. The high point above the shoulders of a horse.

\section{Z}

Zebu. The sacred cattle of India. 


\section{INDEX}

Acclimation fever, 250, 251.

Acid phosphate, 88, 89, 93, 94, 95, 97,98 .

Actinomycosis, or lumpy jaw of eattle, 320.

Alabama Experiment Station,

Depth of plowing, 107.

Experience with fertilizers, 103.

Restorative crops for oats, 159.

Alfalfa, 197, 198.

Alkali land, 17.

Angora goats, 279, 280, 282, 283.

Animal diseases, 250-254; Appendix.

Animal husbandry, 255-257.

Animal manures, 3, 95.

Annual plants, 53.

Anthrax or charbon of stock, 319 .

Arkansas fruit land, 221.

Arkansas rice land, 163, 164.

Arsenate of lead, 302.

Artichoke, Jerusalem, 206.

Ash, 235.

Asparagus, Appendix, 295.

Bacteria, 46-51.

Effects on soils and manures, 47 .

On legumes, 48.

Bad teeth of horse, 315 .

Bagasse, 175.

Balanced ration, 246.

Banana family, 297.

Barley, 155.

Barnyard manure, 95.

Beans, velvet, soy, 196, 197 .

Bees, 284, 285.

Beets, 298.

Beggar weed, 204, 205.

Bennett, Professor R. L., experiments in raising early cotton, 141, $142,143$.

Bermuda grass, 208, 209.

Biennial plants, 53 .
Birds, 133.

Blackberry, 66, 299.

Blackleg, 250, 319.

Black prairie, 20, 21.

Blight, 49.

Blind staggers of horse, 317 .

Boll weevil, 128-134.

Bordeaux mixture, 303.

Borer, Peach, 306.

Budding, 62, 63.

Bur clover, 202.

Burbank, Luther, 76.

Butter making, 289-293.

Cabbage, 229, 230, 231, 299.

Cactus, feeding, 248.

Campbell, H. W., 108, 157.

Capillary attraction, 39.

Carbo-hydrates, 235.

Carbonic acid gas, 2, 6.

Carpet grass, 209.

Cattle, 263-273.

Celery, 216, 233, 299.

Chemistry of soil and products, 31-35.

Cherries, 62.

Chickens, 283, 284.

Chinch bug, 305.

Chinese, plowing land wet, 116.

Methods of growing rice, 162.

Chloro-naphtholium, 318.

Chufa, or grass nut, 206.

Churn, 290.

Citrus Fruits, 224, 225.

Clay and clay-loam soils, 15.

Clover, red, mammoth, crimson, 201204.

Coast prairies, 18.

Coco, or nut-grass, 240.

Cold-frames, 230, 231.

Commercial fertilizers, 98-105.

Complete fertilizer, 93.

Composts and guanos, 92. 
Compounding rations, 244-249.

Concentrates, 236.

Constipation of eattle, 319.

Copper acetate, 301 .

Corn, 149-153.

Corn stover, 152, 153.

Shredded, 152.

Cotton, where grown, 135.

Baling, wrapping, and handling, 145.

Earliness and yield, 143.

Judging, 146.

Planting and cultivating, 138-141.

Size of crop, 135.

Thickness of planting, 144 .

Types to plant for, 143.

Cotton seed, yield of products, 146147.

For feeding, 146.

For fertilizing, 95.

Cowpeas and peanuts, 181-185.

Crab grass, 213, 214.

Cream separator, 290, 291.

Crop rotation, 86-90.

Cross timbers, east and west, 23.

Crossing and hybridizing, 59, 60.

Crude fiber, 238, 239.

Cucumber family, 299.

Cultivating to save moisture, $43,116$.

Cuttings, 65, 66.

Dairy-bred steers for beef, 265, 268.

Dairying, 286-294.

Diseases of animals, 250-254, 315321.

Of plants, 49, 50, 300, 301 .

Ditch, proper shape, 82, 83 .

Dixon, David, 92.

Dog, 321.

Doura corn, 190.

Drainage, $82,83,84$

Draining marsh and creek land, 83.

Dry farming, 108.

Dry matter, digestible nutrients, and fertilizing matter in $100 \mathrm{lb}$. feed stuffs, 240-243.

Earthworms, 80.

Eggplant, 299.
Elements, 30-35.

Elevation and productions, 28, 29.

Evaporation from earth, 42, 43.

From leaves, 41.

Produces cold, 42, 43.

Extensive farming, 215, 216.

Families, economic, of plants, 295300.

Fats, 234, 235.

Feeding animals, 234-249.

Feet of horses, 316.

Fertilizer, stimulating effects, 101, 102.

Fertilizer mixtures, 99, 100.

Manures and, 92-97.

Fertilizers, commercial, 98-105.

Fibrous roots, 56 .

Figs, 221, 222, 223, 298 .

Flies, 127, 128.

Florida beggar weed, 204, 205.

Florida cattle, 270, 271.

Flowers, 58, 59, 60.

Formalin, 228, 319.

Fowls, poultry, 283, 284.

Fruits, 215-225.

Fungicides, 300, 301.

Fungous diseases, 49, 50 .

Gardening, Truek, 227-233.

Geese, 284.

Georgia Experiment Station,

Experience with rotation, 89 .

Rotation subsoiling, 106.

Germs, Bacteria or, 46-50.

Effects on industries, 47 .

Effects on soils and mamures, 47.

Girdler, Twig, 307.

Glacier, 10, 11.

Glanders of horses, 317,318 .

Goosefoot family, 298.

Grade stock, 286, 287.

Grafting, 64, 65.

Grape, 299.

Grape fruit, 224.

Grass family, 296, 297.

Grasses and other forage crops, 208214.

Great plains, 22, 23.

Guanos and composts, 92. 
Guinea and Para grasses, 212, 213.

Hairy vetch, 199.

Hams, Smithfield, 275.

Hawaii, yields of cane, 170 .

Henry's feeds and feeding, 268.

Hog cholera, 253.

Hog raising, 275-279.

Horses and mules, raising, 258-262.

Host, 300.

Hotbed, 229.

Hunter, Dr. IV. D., 129.

Hybrid, 60.

Improving the land, 78, 84 .

Insect friends and enemies, 125134.

Insecticides, 302-304.

Insects, harmful, and remedies, 304307.

Indigestion, of horses, 315 .

Of cattle; 318,319 .

Intensive farming, 215, 216.

Iowa Experiment Station, 268.

Irish potatoes, 227-229, 299.

Irrigation, 119-124.

Amount of water for success, 123.

Arid sections, 120.

For rice, 119.

In humid sections, 120, 121, 122.

Japan clover, 210.

Japanese rice culture, 162.

Japanese persimmon, 63 .

Jerusalem artichoke, 206.

Johnson grass, 210, 211, 212.

Judging, Cotton, 146.

Beef cattle, 312, 313.

Dairy cows, 313, 314.

Draft horses, 308, 309.

Light horses, 310, 311.

Live stock, 308-314.

Kafir corn, 190-195.

Kainit, 93.

Kansas Experiment Station, Experiment with cattle, 268. Subsoiling, 106.
Kerosene emulsion, 302.

Kinds of soil, 15-26.

Larva, Boll weevil, 128.

Layering, 65, 66.

Legumes, bacteria on, 48 .

Lily family, 297 .

Lime, 33.

Lime soil, 19, 20, 21.

Lime sulphur wash, 302.

Liquid manure, 96.

Loam soil, 15.

Louisiana Experiment Station,

Depth for fertilizer, 103.

Rotation, 89.

Lung fever of horses, 316.

Mallein, 317.

Malley, Professor F. W., 129.

Mallow family, 298.

Mammoth clover, 203.

Manures and fertilizers, 92-96.

Materials of commercial fertilizer. 93.

Melilotus, 203, 204.

Melon wilt, 50.

Mexican clover, 204.

Milk fever of cows, 320.

Milo-maize, 190-195.

Minnesota Bulletins on beef cattle, 268.

Mississippi Experiment Station, Beef eattle, 268.

Subsoiling, 106-108.

Mixing fertilizer, 98-101.

Moisture, soil, 37-41.

Mosquitoes, 128.

Muck land, need of potash, 101.

Mulberry, 298.

Mulch, 108.

Mustard family, 298.

Nail prick of horse, 316 .

Nightshade family, 299.

Nitrate of soda, 99 .

Nitrogen, 33.

Nitrogen-free extract, 238, 239.

Nitrogen-gathering erops, 48, 49.

Nodules, or tubercles, 48, 49.

Nutrients, 236. 
Oats, 158.

And vetch, 159 .

Olive family, 300 .

Onion, 232, 233.

Orange family, 299.

Orehard erops, 215-225.

Osmosis, 56, 57.

Palm family, 297.

Para and Guinea grass, 212, 213.

Paris green, 302.

Parsley, 299.

Pasture grasses, 208-214.

Pea family, 299.

Peach, 217-220.

Peanuts, Cowpeas and, 181-1S5.

Pears, 64.

Peas, 181-185.

Pecans, 223, 224.

Budding, 63.

Peppers, 299.

Perennial plants, 53.

Phosphoric acid, 34, 35.

Physies of soil, 37-44.

Pistil, 58.

Plant diseases, 49, 50.

Plant food, proportions from air, earth, and water, 1-4, 6.

Plowing, Deep, 106-108.

Flat or in beds, 112.

In the fall, 113, 114.

To save moisture, 114, 115.

Plows, sandy land, black land, 109.

Plum, 62.

Poisoned bait, 304 .

Pollen, 58.

Pollination, 58, 59, 60.

Poor land, unprofitable, 78.

Potash, 35.

Potassium sulphate, 99.

Potato, Irish, 227-229, 299.

Sweet, 176-180, 228.

Poultry, 283, 284.

Prickly pear, feeding, 248.

Proportions of plant food, 100, 101.

Protein, 234.

Pruning, 219.

Pulling fodder, 152, 153.

Quarantine line, 251, 252.
Rape, 204.

Ration, 244-249.

Balanced, 246.

Razor-backs, 275.

Red lands, 20, 21.

Restorative crops, 88,89

Rice, 162-168.

Oriental methods, 162, 163.

Products in sack of, 167, 168 .

Rock, how made into soil, 8, 9, 10.

Root tubercles, 48, 49.

Roots, 55, 56.

Rotation of erops, 86-91.

Round bales of cotton, 142, 145 .

Rye, 155.

Saccharimeter 172 .

San José scale, 218, 306.

Satsuma orange, 63 .

Scab, potato, 228 .

Scion, 65.

Scours of calves, 318 .

Seed selection, 68-77.

Semiarid soils, Arid and, 15, 16.

Sheep and goats, 279, 280.

Sirup making, 171-173.

Soil, 8.

How formed, 8, 9, 10, 11.

Light and heavy, 26.

Sorghums, 190-195.

Sport, 71, 72.

Spraying, 300, 301.

Stamens, 58.

Stimulating effect of fertilizers, 101, 102.

Stock, 63.

Strawberries, 59, 299.

Subsoil, 8.

Subsoiling, 106, 107.

Sugar cane, 169-175.

Making sirup and sugar, 171-175.

Sulphur spray, 304.

Sunshine, its work, 33, 34 .

Sweet potato, 176-180, 228.

Terracing, 80-82.

Texas Experiment Station, 71, 129.

Texas fever, 250, 251.

Tick, cattle, 127, 128.

Tile draining, 83,84 . 
Tillage, 113-117.

T'oad, 134.

Tobacco, 186-189.

Shade-grown, 187, 188.

Tomato, 229-231.

T'urkeys, 284.

Udder of cows, Disease of, 320, 321.

Vetch, 159.

Vetch, hairy, see Hairy vetch.

Vitality of seed, 70, 71.

Walnut family, 297, 298.

Water, forming soil, 11, 12 .
Water, evaporated from soil, 42, 43. Of soils, 37-42.

Required by crops, 37 .

Weeds, 71 .

Weevil, Cotton boll, 128-134.

Grain, 127.

Whale-oil soap, 303.

Wheat, 154-161.

In a barrel of flour, 157, 158 .

Wind-blown soils, 12 .

Wisconsin Experiment Station, Experiment with hogs, 276.

IVorms of horses, 315 .

Wounds of horse, 318.

Zebu, or sacred cattle, 263, 264. 


MAY 221908

, 



\section{LIBRARY OF CONGRESS}

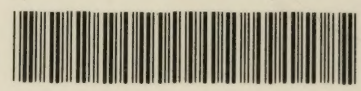

\section{3}

TEXAS EDITION

coNTRuer PRICB - 60 edNTS

EXCHANGE PRICE - 30 CENTS

The prices marked hereon are fixed by the state and deviation therefrom should be reported to the State Superintendent at Austin. Texas. 